\title{
Summary of Notifiable Infectious Diseases and Conditions — United States, 2014
}

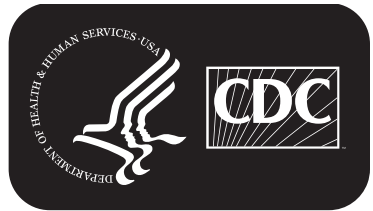




\section{CONTENTS}

Preface... 1

Background 1

Data Sources . .2

Interpreting Data.. . .6

Transitions in NNDSS Data Collection .. .7

Method for Identifying which Nationally Notifiable Infectious

Diseases and Conditions are Reportable . .7

International Health Regulations

Highlights for 2014 10

PART 1

Summary of Notifiable Diseases in the United States, 2014 29

PART 2

Graphs and Maps for Selected Notifiable Diseases in the

United States, 2014 75

Selected Reading for 2014.

The MMWR series of publications is published by the Center for Surveillance, Epidemiology, and Laboratory Services (proposed), Centers for Disease Control and Prevention (CDC), U.S. Department of Health and Human Services, Atlanta, GA 30329-4027.

Suggested citation: Centers for Disease Control and Prevention. [Summary of Notifiable Diseases, 20xx]. Published month day, 20xx for MMWR Morb Mortal Wkly Rep 20xx;63(No. 54):[inclusive page numbers].

\section{Centers for Disease Control and Prevention \\ Thomas R. Frieden, MD, MPH, Director}

Harold W. Jaffe, MD, MA, Associate Director for Science

Joanne Cono, MD, ScM, Director, Office of Science Quality

Chesley L. Richards, MD, MPH, Deputy Director for Public Health Scientific Services

Michael F. Iademarco, MD, MPH, Director, Center for Surveillance, Epidemiology, and Laboratory Services

\section{MMWR Editorial and Production Staff (Serials)}

Sonja A. Rasmussen, MD, MS, Editor-in-Chief

Charlotte K. Kent, PhD, MPH, Executive Editor

Christine G. Casey, MD, Editor

Teresa F. Rutledge, Managing Editor

David C. Johnson, Lead Technical Writer-Editor and Project Editor
Martha F. Boyd, Lead Visual Information Specialist Maureen A. Leahy, Julia C. Martinroe, Stephen R. Spriggs, Moua Yang, Tong Yang, Visual Information Specialists

Quang M. Doan, MBA, Phyllis H. King, Terraye M. Starr, Information Technology Specialists

\section{MMWR Editorial Board}

Timothy F. Jones, MD, Chairman

Matthew L. Boulton, MD, MPH Virginia A. Caine, MD

Katherine Lyon Daniel, PhD

Jonathan E. Fielding, MD, MPH, MBA David W. Fleming, MD
William E. Halperin, MD, DrPH, MPH

King K. Holmes, MD, PhD

Robin Ikeda, MD, MPH

Rima F. Khabbaz, MD

Phyllis Meadows, PhD, MSN, RN

Jewel Mullen, MD, MPH, MPA
Jeff Niederdeppe, $\mathrm{PhD}$

Patricia Quinlisk, MD, MPH

Patrick L. Remington, MD, MPH Carlos Roig, MS, MA

William L. Roper, MD, MPH William Schaffner, MD 


\title{
Summary of Notifiable Infectious Diseases and Conditions - United States, 2014
}

\author{
Deborah A. Adams \\ Kimberly R. Thomas, MPH \\ Ruth Ann Jajosky, DMD \\ Loretta Foster, MPH \\ Pearl Sharp \\ Diana H. Onweh \\ Alan W. Schley \\ Willie J. Anderson \\ for the Nationally Notifiable Infectious Conditions Group \\ Division of Health Informatics and Surveillance, Office of Public Health Scientific Services, CDC
}

\section{Preface}

The Summary of Notifiable Infectious Diseases and ConditionsUnited States, 2014 (hereafter referred to as the summary) contains the official statistics, in tabular and graphic form, for the reported occurrence of nationally notifiable infectious diseases and conditions in the United States for 2014. Unless otherwise noted, data are final totals for 2014 reported as of June 30, 2015. These statistics are collected and compiled from reports sent by U.S. state and territory, New York City, and District of Columbia health departments to the National Notifiable Diseases Surveillance System (NNDSS), which is operated by CDC in collaboration with the Council of State and Territorial Epidemiologists (CSTE). This summary is available at http://www.cdc.gov/mmwr/mmwr_nd/index.html. This site also includes summary publications from previous years.

The Highlights section presents noteworthy epidemiologic and prevention information for 2014 for selected infectious diseases and conditions and additional information to aid in the interpretation of surveillance and infectious diseasesand conditions-trend data. Part 1 contains tables showing incident (new) cases and incidence rates for the nationally notifiable infectious diseases and conditions reported during 2014; these tables do not include rows for conditions with zero cases reported in 2014 (Tables 1,2,3,4,5, and 6).* The tables provide the number of cases reported to CDC for 2014 and the distribution of cases by MMWR month, geographic location, and demographic characteristics (e.g., age, sex, race, and ethnicity). Part 1 also includes a table with the reported incidence of notifiable diseases during 2004-2014 and a table enumerating deaths associated with specified notifiable infectious diseases and conditions reported to CDC's National Center for Health Statistics (NCHS) during 2008-2014

\footnotetext{
* No cases of anthrax; dengue hemorrhagic fever (and dengue shock syndrome), eastern equine encephalitis, nonneuroinvasive disease; poliomyelitis, paralytic; poliovirus infection, nonparalytic; severe acute respiratory syndrome-associated coronavirus disease (SARS-CoV); smallpox; vancomycin-resistant Staphylococcus aureus (VRSA); western equine encephalitis, neuroinvasive and nonneuroinvasive disease; and yellow fever were reported in the United States during 2014.
}

(Tables 7 and 8). Part 2 contains graphs and maps that depict summary data for selected notifiable infectious diseases and conditions described in tabular form in Part 1. Historical notifiable disease data, annotated as Part 3 in previous releases of this summary, will no longer be included in this report. Historical notifiable disease data during 1944-2013 are available online in previous years' summaries (http://www. cdc.gov/mmwr/mmwr_nd). The Selected Reading section presents general and disease-specific references for notifiable infectious diseases and conditions. These references provide additional information on surveillance and epidemiologic concerns, diagnostic concerns, and infectious disease-control activities. To increase the usefulness of future editions, comments regarding the current report and descriptions of how information is or could be used are invited. Comments should be e-mailed to NNDSSweb@cdc.gov with the following subject line: "Annual Summary".

\section{Background}

The infectious diseases and conditions designated by CSTE and CDC as nationally notifiable during 2014 are listed in this section. A notifiable infectious disease or condition is one for which regular, frequent, and timely information regarding individual cases is considered necessary for the prevention and control of the disease or condition. A brief history of the reporting of nationally notifiable infectious diseases and conditions in the United States is available at https://wwwn.cdc. gov/nndss/history.aspx. In 1961, CDC assumed responsibility for the collection of data on nationally notifiable diseases and deaths in 122 U.S. cities. Data are collected through NNDSS, which is neither a single surveillance system nor a method of reporting. Rather, it is a "system of systems", which is coordinated by CDC at the national level across disease-specific programs to optimize data compilation, analysis, and dissemination of notifiable disease data. Monitoring surveillance data enables public health authorities to detect sudden changes in disease 
or condition occurrence and distribution, identify changes in agents and host factors, and detect changes in health-care practices. National level surveillance data are compiled from case notification reports of nationally notifiable infectious diseases and conditions submitted from the state, territory, and selected local health departments to CDC.

Cases are first identified through reports of infectious diseases and conditions from the local level to the state or territory. Legislation, regulation, or other rules in those jurisdictions require health-care providers, hospitals, laboratories, and others to provide information on reportable conditions to public health authorities or their agents. Case reporting at the local level protects the public's health by ensuring the proper identification and follow-up of cases. Public health workers ensure that persons who are already ill receive appropriate treatment; trace contacts who need vaccines, treatment, quarantine, or education; investigate and control outbreaks; eliminate environmental hazards; and close premises where disease transmission is believed to be ongoing.

Although infectious disease and condition reporting is mandated at the state, territory, and local levels by legislation or regulation, state and territory notification to $\mathrm{CDC}$ is voluntary. All U.S. state health departments, five territorial health departments, and two local health departments (New York City and District of Columbia) voluntarily notify CDC about nationally notifiable infectious diseases and conditions which are reportable in their jurisdictions; the data in these case notifications that CDC receives are collected by staff working on reportable disease and condition surveillance systems in local, state, and territorial health departments. Case notification of nationally notifiable infectious diseases and conditions helps public health authorities monitor the effect of these diseases and conditions, measure the disease and condition trends, assess the effectiveness of control and prevention measures, identify populations or geographic areas at high risk, allocate resources appropriately, formulate prevention strategies, and develop public health policies.

The list of nationally notifiable infectious diseases and conditions is revised periodically (Box 1). An infectious disease or condition might be added to the list as a new pathogen emerges, or a disease or condition might be removed as its incidence declines. Public health officials at state and territorial health departments collaborate with CDC staff in determining which infectious diseases and conditions should be considered nationally notifiable. CSTE, with input from CDC, makes recommendations annually for additions and deletions to the list. The list of infectious diseases and conditions considered reportable in each jurisdiction varies over time and across jurisdictions. Current and historic national public health surveillance case definitions used for classifying and enumerating cases consistently at the national level across reporting jurisdictions are available at https://wwwn.cdc.gov/nndss/conditions.

\section{Data Sources}

Provisional data on the reported occurrence of nationally notifiable infectious diseases and conditions are published weekly in MMWR. After each reporting year, staff in state and territory health departments finalize reports of cases for that year with local or county health departments and reconcile the data with reports previously sent to CDC throughout the year. These data are compiled in final form in this summary, which represents the official and archival counts of cases for each year. The data in these reports are approved by the appropriate chief epidemiologist from each submitting state or territory before being published in this summary. Data published in $M M W R$ Surveillance Summaries or other surveillance reports produced by CDC programs might differ from data reported in this summary because of differences in the timing of reports, the source of the data, or surveillance methodology.

Data in this summary were derived primarily from reports transmitted to CDC from health departments in the 50 states, five territories, New York City, and the District of Columbia (reporting jurisdictions). Data were reported for $M M W R$ weeks 1-53, which correspond to the period for the week ending January 4, 2014 through the week ending January 3, 2015. More information regarding notifiable infectious diseases and conditions, including national surveillance case definitions, is available at https://wwwn.cdc.gov/nndss/conditions. Policies for reporting notifiable infectious disease and condition cases can vary by disease, condition, or reporting jurisdiction. The case-status categories used to determine which cases reported to NNDSS are published in the tables are listed by infectious disease or condition in the publication criteria column of the 2014 NNDSS event code list (Box 2).

For a report of a nationally notifiable disease or condition to be published in MMWR (formerly described as "print criteria" and currently described as "publication criteria"), the reporting state or territory must have designated the infectious disease or condition reportable in their state or territory for the year corresponding to the year of report to CDC. After this criterion is met, the infectious disease- or condition-specific criteria listed in the Exhibit are applied. Where the Exhibit indicates that all reports will be published, this means that cases designated with unknown or suspect case confirmation status will be included in the counts along with probable and confirmed cases. Data for new nationally notifiable infectious diseases or conditions are not usually available from reporting jurisdictions until 
BOX 1. Infectious Diseases and Conditions Designated by CSTE and CDC as Nationally Notifiable During 2014*

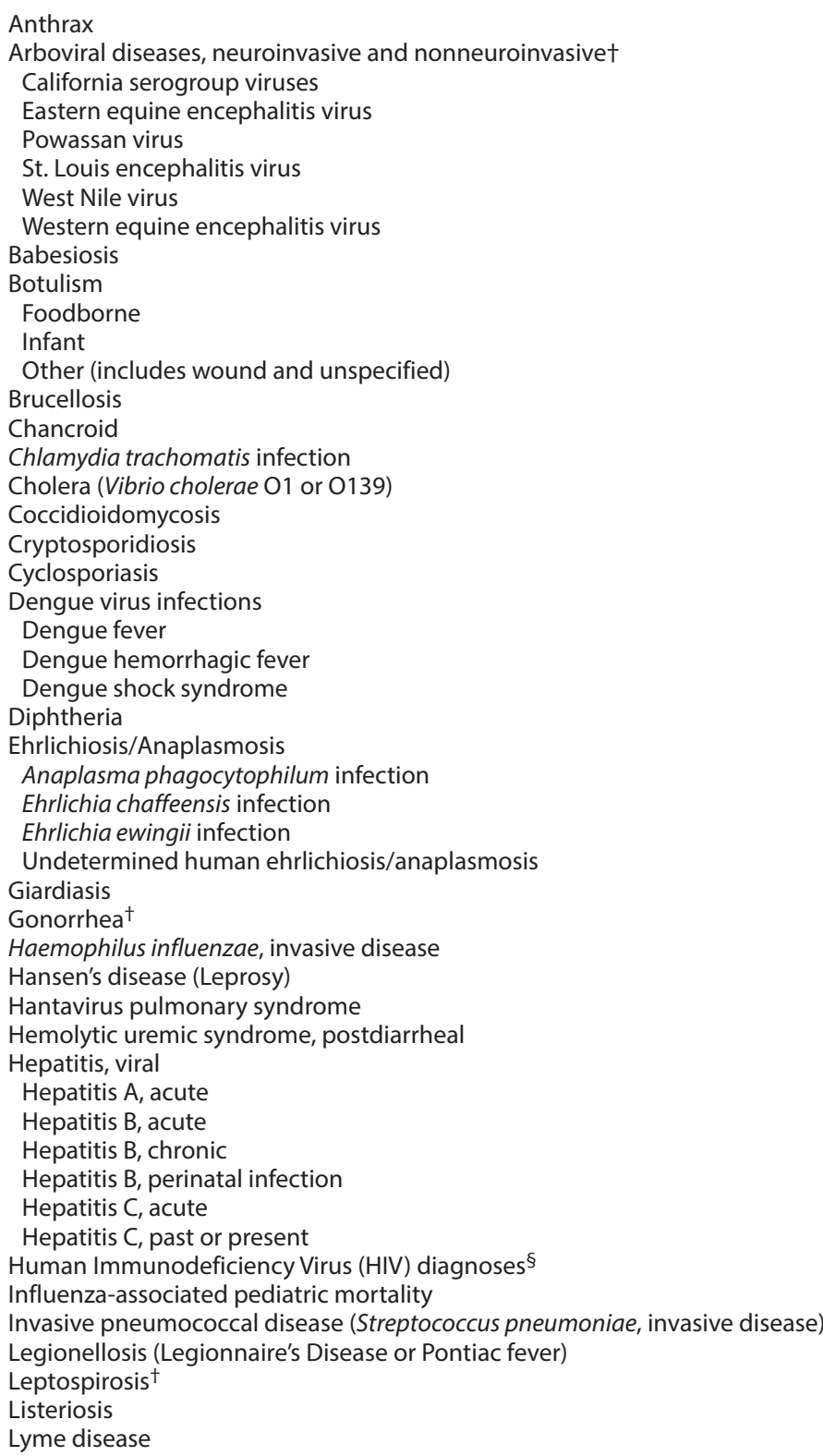

*This list reflects position statements approved in 2013 (or 2012, in the case of leptospirosis) by the Council of State and Territorial Epidemiologists (CSTE) for national surveillance, which were implemented in January 2014. In 2012, CSTE recommended that Leptospirosis be made nationally notifiable, but because of delays in Office of Management and Budget Paperwork Reduction Act approval, it was not added to the list of nationally notifiable conditions until 2014. National surveillance case definitions for these infectious diseases and conditions are available at http://wwwn.cdc.gov/nndss/conditions.

$\dagger$ The year 2014 reflects a modified surveillance case definition for this disease per approved 2013 CSTE position statements.

$\$$ AIDS (Acquired Immunodeficiency Syndrome) has been reclassified as HIV stage III.

Includes the following categories: primary, secondary, latent (including early latent and late latent) and late syphilis with clinical manifestations (including late benign syphilis and cardiovascular syphilis).

January of the year following the approval of the CSTE position statement. In addition, CDC must have Office of Management and Budget Paperwork Reduction Act approval to request data from reporting jurisdictions (1). As a result, there is usually a

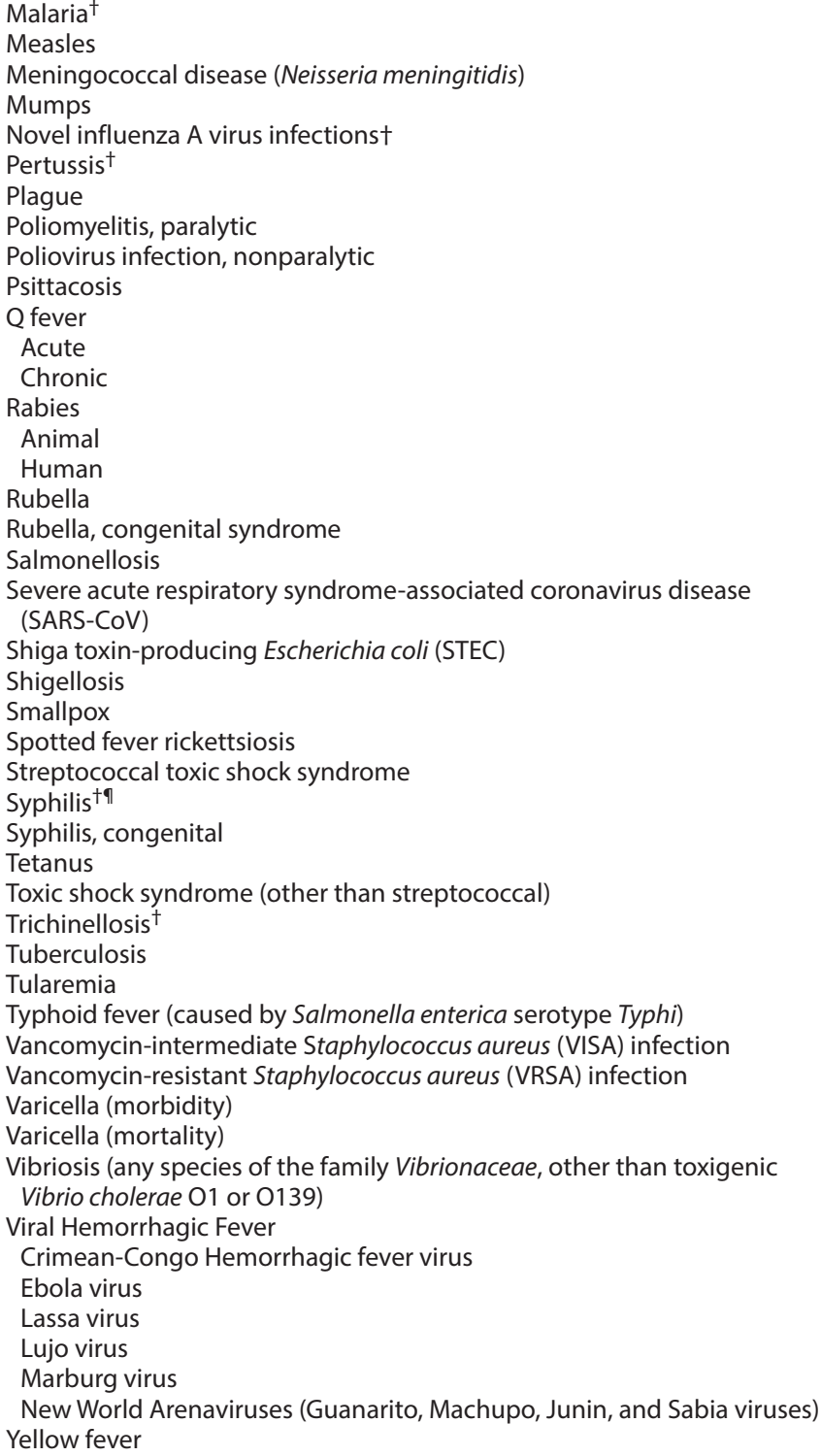


BOX 2. EXHIBIT: Publication criteria and CDC organization responsible for finalizing the data with reporting jurisdictions for notifiable conditions reported to the National Notifiable Diseases Surveillance System, 2014

\begin{tabular}{|c|c|c|c|}
\hline Code & Notifiable condition & Publication criteria ${ }^{*}, t, \S$ & $\begin{array}{l}\text { CDC Organization responsible } \\
\text { for finalizing the data }\end{array}$ \\
\hline 11090 & Anaplasma phagocytophilum & Confirmed and probable & OPHSS \\
\hline 10350 & Anthrax & Confirmed and probable & OPHSS \\
\hline 12010 & Babesiosis & Confirmed and probable & OPHSS \\
\hline 10530 & Botulism, foodborne & Confirmed & OPHSS \\
\hline 10540 & Botulism, infant & Confirmed & OPHSS \\
\hline 10550 & Botulism, other (includes wound) & Confirmed & OPHSS \\
\hline 10548 & Botulism, other (unspecified) & Confirmed & OPHSS \\
\hline 10549 & Botulism, wound & Confirmed & OPHSS \\
\hline 10020 & Brucellosis & Confirmed and probable & OPHSS \\
\hline 10054 & California serogroup virus diseases, neuroinvasive & Confirmed and probable & NCEZID; DVBD \\
\hline 10061 & California serogroup virus diseases, nonneuroinvasive & Confirmed and probable & NCEZID; DVBD \\
\hline 10273 & Chancroid & All reports & NCHHSTP; DSTDP \\
\hline 10274 & Chlamydia trachomatis infection & All reports & NCHHSTP; DSTDP \\
\hline 10470 & Cholera (toxigenic Vibrio cholerae 01 or 0139) & Confirmed & OPHSS \\
\hline 11900 & Coccidioidomycosis & Confirmed & OPHSS \\
\hline 11580 & Cryptosporidiosis & Confirmed and probable & OPHSS \\
\hline 11575 & Cyclosporiasis & Confirmed and probable & OPHSS \\
\hline 10680 & Dengue fever (DF) & Confirmed and probable & NCEZID; DVBD \\
\hline 10685 & Dengue hemorrhagic fever (DHF) (and Dengue shock syndrome (DSS) & Confirmed and probable & NCEZID; DVBD \\
\hline 10040 & Diphtheria & Confirmed, probable, and unknown & OPHSS \\
\hline 10053 & Eastern equine encephalitis virus disease, neuroinvasive & Confirmed and probable & NCEZID; DVBD \\
\hline 10062 & Eastern equine encephalitis virus disease, nonneuroinvasive & Confirmed and probable & NCEZID; DVBD \\
\hline 11088 & Ehrlichia chaffeensis & Confirmed and probable & OPHSS \\
\hline 11089 & Ehrlichia ewingii & Confirmed and probable & OPHSS \\
\hline 11091 & Ehrlichiosis/Anaplasmosis, undetermined & Confirmed and probable & OPHSS \\
\hline 11570 & Giardiasis & Confirmed and probable & OPHSS \\
\hline 10280 & Gonorrhea & All reports & NCHHSTP; DSTDP \\
\hline 10590 & Haemophilus influenzae, invasive disease & Confirmed, probable, and unknown & OPHSS \\
\hline 10380 & Hansen's disease (leprosy) & Confirmed & OPHSS \\
\hline 11590 & Hantavirus pulmonary syndrome (HPS) & Confirmed & NCEZID; DHCPP \\
\hline 11550 & Hemolytic uremic syndrome, postdiarrheal (HUS) & Confirmed and probable & OPHSS \\
\hline 10110 & Hepatitis A, acute & Confirmed & NCHHSTP; DVH \\
\hline 10100 & Hepatitis B, acute & Confirmed & NCHHSTP; DVH \\
\hline 10105 & Hepatitis B, chronic & Confirmed and probable & NCHHSTP; DVH \\
\hline 10104 & Hepatitis B perinatal infection & Confirmed & NCHHSTP; DVH \\
\hline 10101 & Hepatitis C, acute & Confirmed & NCHHSTP; DVH \\
\hline \multirow[t]{2}{*}{10106} & Hepatitis C, past or present & Confirmed and probable & NCHHSTP; DVH \\
\hline & HIV diagnoses & Confirmed & NCHHSTP; DHAP \\
\hline 11061 & Influenza-associated pediatric mortality & Confirmed & NCIRD; ID \\
\hline 11723 & $\begin{array}{l}\text { Invasive Pneumococcal Disease (IPD)/Streptococcus pneumoniae, } \\
\text { invasive disease (all ages) }\end{array}$ & Confirmed & OPHSS \\
\hline 10490 & Legionellosis & Confirmed & OPHSS \\
\hline 10390 & Leptospirosis & Confirmed and probable & OPHSS \\
\hline 10640 & Listeriosis & Confirmed & OPHSS \\
\hline 11080 & Lyme disease & Confirmed and probable & OPHSS \\
\hline 10130 & Malaria & Confirmed & OPHSS \\
\hline 10140 & Measles (rubeola), total & Confirmed and unknown & OPHSS \\
\hline 10150 & Meningococcal disease (Neisseria meningitidis) & Confirmed and probable & OPHSS \\
\hline 10180 & Mumps & Confirmed, probable, and unknown & OPHSS \\
\hline 11062 & Novel influenza A virus infections, initial detections of & Confirmed & NCIRD; ID \\
\hline 10190 & Pertussis (Whooping Cough) & Confirmed, probable, and unknown & OPHSS \\
\hline 10440 & Plague & All reports & OPHSS \\
\hline 10410 & Poliomyelitis, paralytic & Confirmed & OPHSS \\
\hline 10405 & Poliovirus infection, nonparalytic & Confirmed & OPHSS \\
\hline 10057 & Powassan virus disease, neuroinvasive & Confirmed and probable & NCEZID; DVBD \\
\hline 10063 & Powassan virus disease, nonneuroinvasive & Confirmed and probable & NCEZID; DVBD \\
\hline 10450 & Psittacosis (Ornithosis) & Confirmed and probable & OPHSS \\
\hline 10257 & Q fever, acute & Confirmed and probable & OPHSS \\
\hline 10258 & Q fever, chronic & Confirmed and probable & OPHSS \\
\hline 10340 & Rabies, animal & Confirmed & NCEZID; DHCPP \\
\hline 10460 & Rabies, human & Confirmed & NCEZID; DHCPP \\
\hline 10200 & Rubella & Confirmed and unknown & OPHSS \\
\hline 10370 & Rubella, congenital syndrome (CRS) & Confirmed, probable, and unknown & OPHSS \\
\hline
\end{tabular}


BOX 2. EXHIBIT: (Continued) Publication criteria and CDC organization responsible for finalizing the data with reporting jurisdictions for notifiable conditions reported to the National Notifiable Diseases Surveillance System, 2014

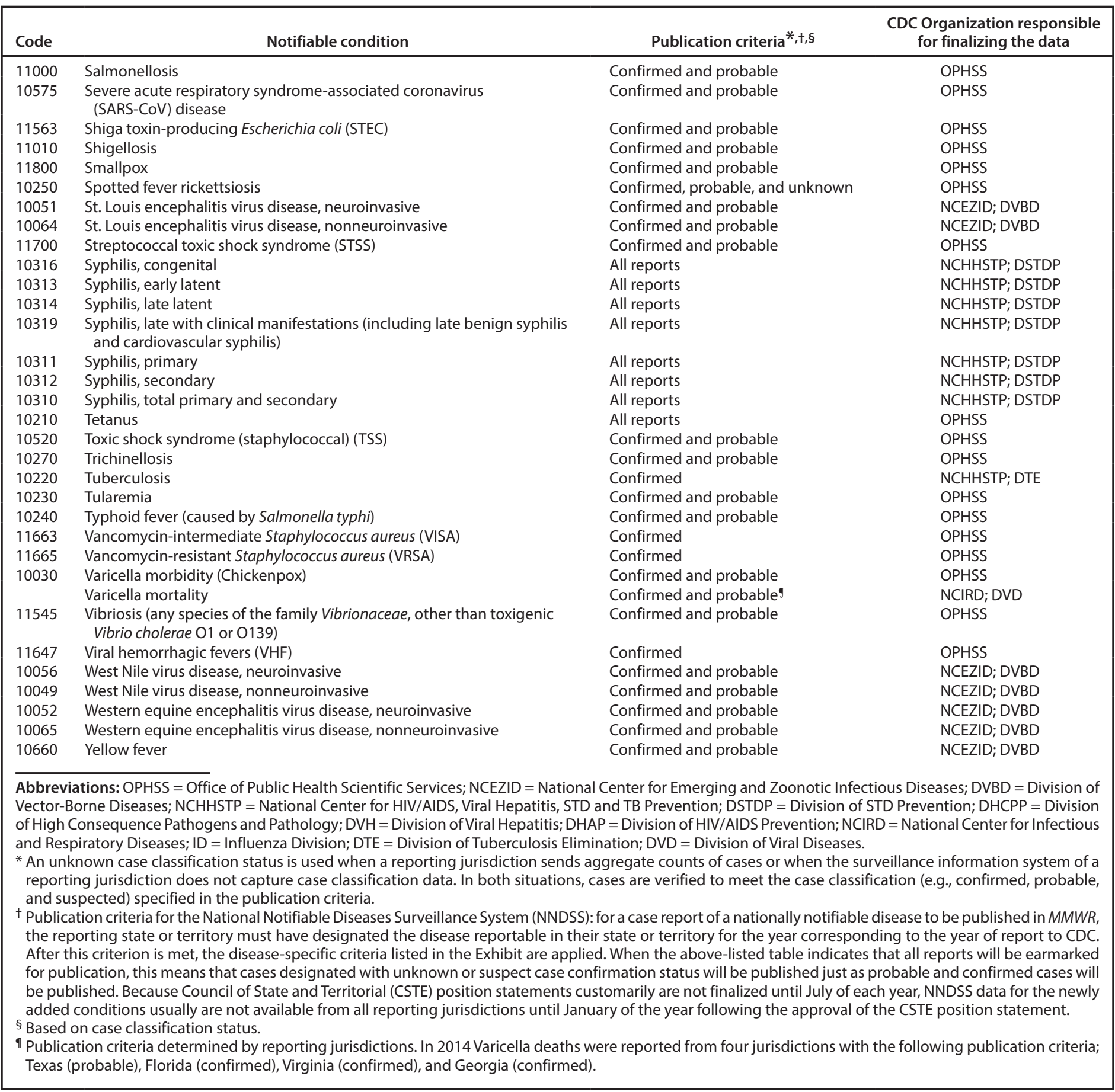

Final data for certain infectious diseases and conditions are derived from the surveillance records of the CDC program. Requests for further information regarding these data should be directed to the appropriate program. The CDC organization responsible for finalizing the data used for the final $M M W R$ tables for each condition is listed in the Exhibit.
Population estimates were obtained from the NCHS postcensal estimates of the resident population of the United States during July 1, 2013-July 1, 2014, by year, county, single year of age (range: 0 to $\geq 85$ years), bridged-race (white, black or African American, American Indian or Alaska Native, Asian, or Pacific Islander), Hispanic ethnicity (not Hispanic or 
Latino, Hispanic or Latino), and sex (Vintage 2014), prepared under a collaborative arrangement with the U.S. Census Bureau. Population estimates for states as of June 25, 2015 are available at http://www.cdc.gov/nchs/nvss/bridged_race/data_ documentation.htm\#vintage2014. Population estimates for territories are from the 2014 U.S. Census Bureau International Data Base, available at http://www.census.gov/population/ international/data/idb/informationGateway.php. The choice of population denominators for incidence reported in $M M W R$ is based on the availability of census population data at the time of preparation for publication and the desire for consistent use of the same population data to compute incidence reported by different CDC programs.

Incidence in this summary was calculated as the number of reported cases for each infectious disease or condition divided by either the U.S. resident population for the specified demographic population or the total U.S. resident population, multiplied by 100,000 . For Territories, incidence in this summary was calculated as the number of reported cases for each infectious disease or condition divided by either the territorial resident population for the specified demographic population or the total territorial resident population, multiplied by 100,000 . When a nationally notifiable infectious disease or condition is associated with a specific age restriction, the same age restriction was applied to the population in the denominator of the incidence calculation. In addition, population data from states in which the disease or condition was not reportable or was not available are excluded from incidence calculations. Unless otherwise stated, disease totals for the United States do not include data for American Samoa, Guam, Puerto Rico, the Commonwealth of the Northern Mariana Islands, or the U.S. Virgin Islands.

\section{Interpreting Data}

The completeness of information on notifiable infectious diseases and conditions was highly variable and related to the disease or condition being reported (2-9). Incidence data in this summary are presented by the MMWR week and year (https://wwwn.cdc. gov/nndss/document/MMWR_Week_overview.pdf) assigned by the state or territorial health department, with some exceptions, including human immunodeficiency virus (HIV) (presented by date of diagnosis), tuberculosis (presented by date CDC surveillance staff verified that the case met the criteria in the national surveillance case definition), domestic arboviral diseases (presented by date of illness onset), and varicella deaths (presented by date of death). Data were reported by the jurisdiction of the person's "usual residence" at the time of disease or condition onset (https://wwwn. cdc.gov/nndss/document/11-SI-04.pdf). For certain nationally notifiable infectious diseases and conditions, surveillance data are reported independently to various $\mathrm{CDC}$ programs. For this reason, surveillance data reported by other CDC programs might vary from data reported in this summary because of differences in 1) the date used to aggregate data (e.g., date of report or date of disease or condition occurrence), 2) the timing of reports, 3) the source of the data, 4) surveillance case definitions, and 5) policies regarding case jurisdiction (i.e., which jurisdiction should submit the case notification to $\mathrm{CDC}$ ). In addition, the "date of disease occurrence" of conditions might vary. For infectious diseases, the meaning of the "date of disease occurrence" varies across jurisdictions and by disease and might be a date of symptom or disease onset, diagnosis, laboratory result, reporting of a case to a jurisdiction, or notification of a case to CDC.

Data reported in this summary are useful for analyzing infectious disease or condition trends and determining relative infectious disease or condition numbers. However, reporting practices affect how these data should be interpreted. Infectious disease and condition reporting is likely incomplete, and completeness might vary depending on the infectious disease or condition and reporting state. The degree of completeness of data reporting also might be influenced by the diagnostic facilities available, control measures in effect, public awareness of a specific infectious disease or condition, and the resources and priorities of state and local officials responsible for public health surveillance and for controlling infectious diseases and conditions. Finally, factors such as changes in methods for public health surveillance, introduction of new diagnostic tests, or discovery of new infectious disease or condition entities can cause changes in reporting that are independent of the actual incidence of infectious disease or condition.

Public health surveillance data are published for selected racial/ethnic populations because these characteristics can be risk markers for certain notifiable infectious diseases or conditions. Race and ethnicity data also can be used to highlight populations for focused prevention programs. However, caution must be used when drawing conclusions from reported race and ethnicity. Different racial/ethnic populations might have different patterns of access to health care, potentially resulting in data that are not representative of actual infectious disease or condition incidence among specific population groups. In addition, not all race and ethnicity data are collected or reported uniformly for all infectious diseases and conditions; for example, the recommended standard for classifying a person's race or ethnicity is based on self-reporting. However, this procedure might not always be followed.

Surveillance data reported to NNDSS are in either individual case-specific form or summary form (i.e., aggregated data for a group of cases). Summary data often lack demographic information (e.g., race); therefore, the demographic-specific rates presented in this summary might be underestimated. 


\section{Transitions in NNDSS Data Collection}

Data collection in NNDSS has undergone various transitions over time. Before 1990, data were reported to CDC as cumulative counts rather than as individual case reports. In 1990, using the National Electronic Telecommunications System for Surveillance (or NETSS), states began electronically capturing and reporting individual cases to $\mathrm{CDC}$ without personal identifiers. In 2001, CDC launched the National Electronic Disease Surveillance System (NEDSS) to promote the use of data and information system standards that advance the development of efficient, integrated, and interoperable surveillance information systems at the local, state, territorial, and national levels. Reporting jurisdictions now use integrated surveillance information systems based on NEDSS architectural standards to submit NNDSS data to CDC. Additional information concerning NEDSS is available at https://wwwn.cdc.gov/nndss/nedss.aspx.

In 2013, CDC began to conceptualize improvements to strengthen and modernize the technical infrastructure supporting NNDSS. In 2014, CDC and selected states began work on the NNDSS Modernization Initiative (NMI), a multiyear commitment to enhance NNDSS surveillance capabilities. An important benefit for public health decision making will be the ability to acquire higher quality data that are more comprehensive and timely. Through NMI, CDC and its state partners will increase the robustness of the NNDSS technological infrastructure so that it is based on interoperable, standardized data and data exchange mechanisms. Additional information is available at http://www.cdc.gov/nmi.

\section{Method for Identifying which Nationally Notifiable Infectious Diseases and Conditions are Reportable}

States and jurisdictions are sovereign entities. Reportable conditions are determined by the laws and regulations of each state, territory, or local jurisdiction. Some infectious diseases and conditions deemed nationally notifiable by CSTE might not be designated as reportable in certain states or jurisdictions. Only data from reporting states, territories, and jurisdictions that designated the infectious disease or condition as reportable are included in the summary tables. This ensures the data displayed in this summary are from population-based surveillance efforts and are generally comparable across states, territories, and other jurisdictions. When a CSTE- and CDCrecommended nationally notifiable disease or condition is not reportable by state, territory, or other jurisdiction officials, an "N" indicator for "not reportable" is inserted in the table for the specified reporting state, territory, or jurisdiction and applicable year. Each year, the NNDSS Data Processing Team solicits information from each NNDSS reporting state, territory, and jurisdiction (all 50 U.S. states, the District of Columbia, New York City, and five U.S. territories) about whether reporting is mandated by law or regulation for each nationally notifiable condition.

\section{International Health Regulations}

At its annual meeting in June 2007, CSTE approved a position statement that supports implementation of International Health Regulations (IHR) in the United States (10). CSTE approval followed the adoption of revised IHR in May 2005 by the World Health Assembly (11) that went into effect in the United States on July 18, 2007. This international legal instrument governs the role of the World Health Organization (WHO) and its member countries, including the United States, in identifying, responding to, and sharing information about events that might constitute a Public Health Emergency of International Concern (PHEIC). A PHEIC is an extraordinary event that constitutes a public health risk to other countries through international spread of disease and potentially requires a coordinated international response. All $\mathrm{WHO}$ member countries are required to notify WHO of a potential PHEIC. WHO makes the final determination about the existence of a PHEIC.

Health care providers in the United States are required to report diseases, conditions, and outbreaks determined to be reportable by local, state, or territorial law or regulation. In addition, all health care providers should work with their local, state, or territorial health agencies to identify and report events occurring in their location that might constitute a PHEIC. U.S. state and territorial departments of health report information about a potential PHEIC to the most relevant federal agency responsible for monitoring such an event. In the case of human infectious disease, the U.S. state or territorial departments of health notifies CDC through existing formal and informal reporting mechanisms (10). CDC further analyzes the event by use of the decision algorithm in Annex 2 of the IHR and notifies the U.S. Department of Health and Human Services (HHS) Secretary's Operations Center (SOC), as appropriate. The HHS SOC is responsible for reporting a potential PHEIC to WHO.

In the United States, HHS has the lead role in carrying out IHR, in cooperation with multiple federal departments and agencies. When a potential PHEIC is identified, the United States has 48 hours to assess the risk of the reported event. If authorities determine that a potential PHEIC exists, the United 
States, as with all WHO member countries, has 24 hours to report the event to WHO. The HHS SOC is responsible for reporting a potential PHEIC to WHO.

An IHR decision algorithm (Annex 2 of the IHR) was developed to help countries determine whether an event should be reported. If any two of the following four questions are answered in the affirmative, then a potential PHEIC exists and WHO should be notified:

- Is the public health impact of the event serious?

- Is the event unusual or unexpected?

- Is there a significant risk of international spread?

- Is there a significant risk for international travel or trade restrictions?

The revised IHR reflects a conceptual shift from the use of a predefined disease list to a framework of reporting and responding to events on the basis of an assessment of public health criteria, including seriousness, unexpectedness, and international travel and trade implications. A PHEIC is an event that falls within those criteria (further defined in a decision algorithm in Annex 2 of the revised IHR); however, any one of the following four conditions always constitutes a PHEIC and do not require the use of the IHR decision instrument in Annex 2:

- severe acute respiratory syndrome (SARS),

- smallpox,

- poliomyelitis caused by wild-type poliovirus, and

- human influenza caused by a new subtype.

Examples of events that require the use of the decision instrument include, but are not limited to cholera, pneumonic plague, yellow fever, West Nile fever, viral hemorrhagic fevers, and meningococcal disease. Other biologic, chemical, or radiologic events that fit the decision algorithm also must be reported to WHO.

Additional information about IHR is available at http:// www.who.int/ihr/publications/9789241580496/en, http:// www.cdc.gov/globalhealth/ihregulations.htm, and http://www. cdc.gov/globalhealth/healthprotection/ghs/ihr/index.html. CSTE also approved a position statement that added initial detections of novel influenza A virus infections to the list of nationally notifiable infectious diseases, beginning in January 2007, to in part support the implementation of the revised IHR in the United States to identify human influenza caused by a new subtype (12).

\section{Acknowledgements}

We acknowledge all the local, state, and territorial health departments in the United States for collecting the data included in this report from a range of case ascertainment sources (e.g., health-care providers, hospitals, laboratories) and for reporting these data to CDC.

\section{References}

1. U.S. Department of Health and Human Services. Information Collection and Paperwork Reduction Act (PRA) overview. Washington, DC: U.S. Department of Health and Human Services; 2015. https://www.usability. gov/how-to-and-tools/guidance/pra-overview.html

2. Doyle TJ, Glynn MK, Groseclose SL. Completeness of notifiable infectious disease reporting in the United States: an analytical literature review. Am J Epidemiol 2002;155:866-74. http://dx.doi.org/10.1093/ aje/155.9.866

3. CDC. Assessing completeness of perinatal hepatitis B virus infection reporting through comparison of immunization program and surveillance data-United States. MMWR Morb Mortal Wkly Rep 2011;60:410-3.

4. CDC. Evaluation of acute hepatitis $\mathrm{C}$ infection surveillanceUnited States, 2008. MMWR Morb Mortal Wkly Rep 2010;59:1407-10.

5. Hwang J, McClintock S, Kachur SP, Slutsker L, Arguin P. Comparison of national malaria surveillance system with the national notifiable diseases surveillance system in the United States. J Public Health Manag Pract 2009;15:345-51.

6. Painter JE, Hlavsa MC, Collier SA, Xiao L,Yoder JS. Cryptosporidiosis surveillance-United States, 2011-2012. MMWR Surveill Summ 2015;64(No. SS-3).

7. Painter JE, Gargano JW, Collier SA, Yoder JS. Giardiasis surveillanceUnited States, 2011-2012. MMWR Suppl 2015;64(No SS-3):15-25.

8. Wilson NO, Hall RL, Montgomery SP, Jones JL. Trichinellosis surveillance-United States, 2008-2012. MMWR Surveill Summ 2015;64(No. SS-1):1-8.

9. CDC. Babesiosis surveillance-18 States, 2011. MMWR Morb Mortal Wkly Rep 2012;61:505-9.

10. Council of State and Territorial Epidemiologists. Events that may constitute a public health emergency of international concern. Position statement 07-ID-06. http://c.ymcdn.com/sites/www.cste.org/resource/ resmgr/PS/07-ID-06.pdf

11. World Health Organization. International Health Regulations, Second ed. Geneva, Switzerland: World Health Organization; 2005. http://apps.who.int/iris/bitstream/10665/43883/1/9789241580410_ eng.pdf

12. Council of State and Territorial Epidemiologists. Council of State and Territorial Epidemiologists position statement; 2007. National reporting for initial detections of novel influenza A viruses. http://c.ymcdn.com/ sites/www.cste.org/resource/resmgr/PS/07-ID-01.pdf 


\section{Nationally Notifiable Infectious Conditions Group}

Paul M. Arguin, MD, Aileen Artus, MPH, Kaitlin Benedict, MPH, David D. Blaney, MD, Jesse Blanton, MPH, Anna Bowen, MD, William A. Bower, MD, Elizabeth C. Briere, MD, Kevin Chatham-Stephens, MD, Tom Chiller, MD, Mary Choi, MD, Nakia Clemmons, MPH, Shannon Cooney, MPH, Karen A. Cullen, PhD, F. Scott Dahlgren, MSPH, Annabelle de St Maurice, MD, Naomi Drexler, MPH, Elizabeth Ervin, MPH, Amanda E. Faulkner, MPH, Marc Fischer, MD, Kathleen E. Fullerton, MPH, Julia Warner Gargano, PhD, Laurel E. Garrison, MPH, Hannah Gould, PhD, Elizabeth B. Gray, MPH, Marta Guerra, DVM, Rebecca Hall, MPH, Kristen Nichols Heitman, MPH, Katherine A. Hendricks, MD, Barbara L. Herwaldt, MD, Michele C. Hlavsa, MPH, Scott Holmberg, MD, Jacqueline Hurd, MPH, Martha Iwamoto, MD, Kelly A. Jackson, MPH, Ruth Jiles, PhD, Anna Satcher Johnson, MPH, Jeffrey Jones, MD, Michael Judd, MPH, Grishma A. Kharod, MPH, Sarah Kidd, MD, Robert Kirkcaldy, MD, Barbara Knust, DVM, Kiersten J. Kugeler, PhD, Ben Kupronis, MPH, Amanda N. Lankford, Jennifer Lehman, Nicole Lindsey, MPH, Adriana Lopez, MHS, Kimberly E. Mace, PhD, Jessica R. MacNeil, MPH, Barbara Mahon, MD, Lilia P. Manangan, MPH, Stacey W. Martin, MSc, Robert F. Massung, PhD, Orion McCotter, MPH, Paul S. Mead, MD, Rajal K. Mody, MD, Susan Montgomery, DVM, Anna Newton, MPH, Christopher D. Paddock, MD, Emily Pieracci, DVM, Robert H. Pratt, Rodney Presley, PhD, Lawrence Purpura, MD, Susan Redd, Pierre Rollin, MD, Ilana J. Schafer, DVM, Sean V. Shadomy, DVM, Tyler M. Sharp, PhD, Tami H. Skoff, MS, Erin Staples, MD, Tara Strine, PhD, Tejpratap S.P. Tiwari, MD, Elizabeth Torrone, PhD, Rita M. Traxler, MHS, Gregory Wallace, MD, Ryan Wallace, DVM, Hillard Weinstock, MD, Emily Weston, MPH, CDC. 


\section{Highlights for 2014}

\section{Anthrax}

The U.S. Food and Drug Administration (FDA) has approved two antitoxin treatments for inhalation anthrax: anthrax immune globulin intravenous (human) (i.e., Anthrasil) (1) and raxibacumab (2). These therapeutics are held in the Strategic National Stockpile, and requests for use must be made to CDC. Antitoxins, in combination with antimicrobials and supportive therapies, are recommended for treatment of systemic anthrax. In addition, anthrax vaccine adsorbed (i.e., BioThrax) is FDA-approved as a 3-dose postexposure prophylaxis (PEP) series, along with antimicrobials, to prevent anthrax in adults exposed to Bacillus anthracis (3). PEP and treatment recommendations exist for multiple populations, including children, pregnant and postpartum women, and adults for conventional and mass casualty settings (4-7).

1. Food and Drug Administration. FDA approves treatment for inhalation anthrax. 2015. http://www.fda.gov/NewsEvents/Newsroom/ PressAnnouncements/ucm 439752.htm

2. Food and Drug Administration. FDA approves raxibacumab to treat inhalational anthrax. 2012. http://www.fda.gov/NewsEvents/Newsroom/ PressAnnouncements/ucm332341.htm

3. Food and Drug Administration. FDA approves vaccine for use after known or suspected anthrax exposure. 2015. http://www.fda.gov/NewsEvents/ Newsroom/PressAnnouncements/ucm474027.htm

4. Bradley JS, Peacock G, Krug SE, et al. Pediatric anthrax clinical management. Pediatrics 2014;133:e1411-36. http://dx.doi.org/10.1542/ peds.2014-0563

5. Hendricks KA, Wright ME, Shadomy SV, et al. Centers for disease control and prevention expert panel meetings on prevention and treatment of anthrax in adults. Emerg Infect Dis 2014. http://dx.doi.org/10.3201/ eid2002.130687

6. Meaney-Delman D, Zotti ME, Creanga AA, et al. Special considerations for prophylaxis for and treatment of anthrax in pregnant and postpartum women. Emerg Infect Dis 2014. http://dx.doi.org/10.3201/eid2002.130611

7. Bower WA, Hendricks K, Pillai S, Guarnizo J, Meaney-Delman D. Clinical framework and medical countermeasure use during an anthrax mass-casualty incident. MMWR Recomm Rep 2015;64(No. RR-4).

\section{Domestic Arboviral Disease, Neuroinvasive and Nonneuroinvasive}

In 2014, a total of 2,205 West Nile virus (WNV) disease cases were reported, including 1,347 cases of neuroinvasive disease (e.g., meningitis, encephalitis, and acute flaccid paralysis) and 97 deaths (1). WNV disease cases were reported from 42 states and the District of Columbia. Three states reported two thirds $(66 \%)$ of the WNV neuroinvasive disease cases: California (561 cases), Texas (253), and Arizona (80). The incidence of neuroinvasive disease was similar to the median incidence during 2002-2013 (median $=0.40$; range $=0.13-1.02$ )
However, California reported a record 561 neuroinvasive disease cases, $83 \%$ more than the next highest year (2005). In California, $70 \%$ of all neuroinvasive disease cases were reported from two counties (Los Angeles and Orange). These findings underscore the focal nature of WNV outbreaks.

After WNV, the next most commonly reported cause of neuroinvasive arboviral disease was La Crosse virus, followed by Jamestown Canyon virus, St. Louis encephalitis virus, Powassan virus, and Eastern equine encephalitis virus. Jamestown Canyon virus disease cases continue to be reported from new locations (e.g., Tennessee) following the implementation of routine Jamestown Canyon virus antibody testing at CDC in 2013 (2). Although rare, Eastern equine encephalitis virus disease remained the most severe arboviral disease, with two deaths among eight patients.

1. Lindsey NP, Lehman JA, Staples JE, Fischer M. West Nile virus and other nationally notifiable arboviral diseases-United States, 2014. MMWR Morb Mortal Wkly Rep 2015;64:929-34. http://dx.doi.org/10.15585/ mmwr.mm6434a1

2. Pastula DM, Hoang Johnson DK, White JL, Dupuis AP 2nd, Fischer M, Staples JE. Jamestown Canyon virus disease in the United States-2000-2013. Am J Trop Med Hyg 2015;93:384-9. http:// dx.doi.org/10.4269/ajtmh.15-0196

\section{Babesiosis}

Babesiosis is caused by protozoan parasites of the genus Babesia, which infect red blood cells. Babesia infection can range from asymptomatic to life threatening. Clinical manifestations can include fever, chills, other nonspecific influenza-like symptoms, and hemolytic anemia. Babesia parasites usually are tickborne but also can be transmitted via blood transfusion or congenitally (1).

In 2014, a total of $1,744^{*}$ cases of babesiosis were reported to CDC. Babesiosis cases were reported by 22 of the 31 states in which babesiosis was a reportable condition; $94 \%$ $(1,636)$ of the reported cases occurred in residents of seven states (Connecticut, Massachusetts, Minnesota, New Jersey, New York, Rhode Island, and Wisconsin). The median age of patients was 63 years (range: $<1-96$ years); 65\% $(1,131)$ were male, and sex was unknown for $<1 \%$ (six). Among the 1,340 patients for whom data were available, $84 \%(1,124)$ had symptom onset dates during June-August.

\footnotetext{
*This number differs slightly from the denominator of 1,760 presented in Table 2, which includes 22 erroneous reports not retracted before the deadline for finalizing the data. In addition, six cases that were reported after the deadline are included at the request of the pertinent health departments.

1. Herwaldt BL, Linden JV, Bosserman E, Young C, Olkowska D, Wilson M. Transfusion-associated babesiosis in the United States: a description of cases. Ann Intern Med 2011;155:509-19. http://dx.doi. org/10.7326/0003-4819-155-8-201110180-00362
} 


\section{Botulism}

Botulism is a severe paralytic illness caused by toxins produced by Clostridium botulinum. Exposure to the toxin can occur by ingestion (foodborne botulism), in situ production from C. botulinum colonization of either a wound (wound botulism) or the gastrointestinal tract (infant botulism and adult intestinal colonization botulism), or overdose of botulinum toxin used for cosmetic or therapeutic purposes (1). In 2014, a total of 161 cases of botulism were reported, including 127 cases in infants, 15 foodborne cases, and 19 cases classified as other, including wound botulism. During 2014, four outbreaks (events with two or more cases) of foodborne botulism were reported. One outbreak was associated with stinkheads (fermented whitefish heads, a traditional Alaska Native food) (three cases), one with seal oil (three cases), one with home-canned tomato sauce (two cases), and one with pasta and jarred pesto (two cases). The jarred pesto was produced in a home kitchen, sold commercially, and then mixed with the pasta by one of the cases; the only leftovers available for testing were the pesto and pasta mixed together.

All states maintain 24-hour telephone services for reporting of botulism and other public health emergencies. Health care providers should report suspected botulism cases immediately to their state health departments. CDC maintains intensive surveillance for cases of botulism in the United States and provides consultation and antitoxin for suspected cases. State health departments can reach the CDC botulism duty officer on call 24 hours a day, 7 days a week via the CDCEmergency Operations Center (telephone: 770-488-7100).

1. Sobel J. Botulism. Clin Infect Dis 2005;41:1167-73. http://dx.doi. org/10.1086/444507

\section{Brucellosis}

During 2014, a total of 92 human brucellosis cases were reported in the United States; 58 were among men. Cases were distributed throughout the United States, with the South Atlantic and Pacific regions having the highest number of reported cases (19 and 25, respectively). Persons who consume raw (unpasteurized) dairy products might be at increased risk for exposure to Brucella spp., which can cause brucellosis (1). Feral swine hunters also are considered an at-risk population (2).

1. CDC. Risks from unpasteurized dairy products. http://www.cdc.gov/ brucellosis/exposure/unpasteurized-dairy-products.html

2. CDC. Hunters risks. http://www.cdc.gov/brucellosis/exposure/hunters.html

\section{Chlamydia}

Chlamydia trachomatis is the most commonly reported nationally notifiable infectious disease in the United States;
$1,441,789$ cases were reported to CDC in 2014. Following a slight decline during 2012-2013, the national rate of reported chlamydial infection increased $2.8 \%$ during 2013-2014, ${ }^{*}$ from 443.5 to 456.1 per 100,000 population (1). Rates were highest among females aged 15-19 years (2,941.0 cases per 100,000 females) and 20-24 years $(3,651.1)$. The rate among women aged 15-19 years increased steadily during 2000-2011, but decreased 4.4\% during 2011-2012, 7.9\% during 2012-2013, and $4.2 \%$ during 2013-2014. As in previous years, rates of reported chlamydia were highest among non-Hispanic blacks. The rate of reported chlamydia among black females aged 15-19 years was 4.9 times the rate among white females in the same age group. Most chlamydial infections are asymptomatic, and rates of reported cases are affected by the diagnostic test used and the proportion of the population screened. Consequently, increases in case rates might reflect expanded screening coverage, use of more sensitive diagnostic tests, and increases in incidence of infection. Likewise, decreases in rates of reported chlamydial infections might suggest decreases in incidence of infection or decreases in screening coverage.

\footnotetext{
* Rates for 2014 were calculated using the 2013 population estimates and differ from 2014 rates presented in the figures and table 7 (calculated using 2014 population estimates).
}

1. CDC. Sexually transmitted disease surveillance 2014. Atlanta, GA: US Department of Health and Human Services, CDC; 2015.

\section{Cholera}

Cholera continues to be rare in the United States and is most often acquired during travel in countries where toxigenic Vibrio cholerae $\mathrm{O} 1$ or $\mathrm{O} 139$ is circulating $(1-3)$. Of the five cholera infections in 2014, all were travel-associated (two with travel to Cuba, two to India, and one to Ghana). Although cholera is endemic in many African countries, the patient who traveled to Ghana is the first since 2011 to be associated with travel to an African country (4).

1. Steinberg EB, Greene KD, Bopp CA, Cameron DN, Wells JG, Mintz ED. Cholera in the United States, 1995-2000: trends at the end of the twentieth century. J Infect Dis 2001;184:799-802. http://dx.doi. org/10.1086/322989

2. Newton AE, Heiman KE, Schmitz A, et al. Cholera in United States associated with epidemic in Hispaniola. Emerg Infect Dis 2011;17:21668. http://dx.doi.org/10.3201/eid1711.110808

3. Loharikar A, Newton AE, Stroika S, et al. Cholera in the United States, 2001-2011: a reflection of patterns of global epidemiology and travel. Epidemiol Infect 2015;143:695-703. http://dx.doi.org/10.1017/ S0950268814001186

4. Mintz ED, Guerrant RL. A lion in our village-the unconscionable tragedy of cholera in Africa. N Engl J Med 2009;360:1060-3. http:// dx.doi.org/10.1056/NEJMp0810559 


\section{Coccidioidomycosis}

Coccidioidomycosis (i.e., Valley fever) is a fungal infection caused by inhalation of Coccidioides spp. spores that are present in the arid soil of the southwestern United States, California, and parts of Central and South America. Coccidioides also was recently identified in soil in south-central Washington in association with cases of human disease (1). After a substantial increase during 1998-2011 (2), the number of cases has decreased each year since then, including a $13 \%$ decrease in the number of cases from 2013 to 2014 (9,438 and 8,232, respectively). Historically, Arizona and California have had the highest number of reported coccidioidomycosis cases. Arizona, which reported the most cases $(5,624)$ of any state in 2014, experienced a $4 \%$ decrease in the number of cases compared with 2013 (5,861 cases). California reported the second-highest number of cases $(2,243)$ of any state in 2014 and experienced a 31\% decrease compared with 2013 (3,272 cases).

Reasons for the overall decrease in reported cases might, in part, be related to changes in the environment or changes in the at-risk population. Physicians should continue to maintain a high suspicion for acute coccidioidomycosis in patients who live in or have traveled to areas in which the disease is endemic and should be aware of the possibility for coccidioidomycosis outside of its previously recognized geographic range.

1. Litvintseva AP, Marsden-Haug N, Hurst S, et al. Valley fever: finding new places for an old disease: Coccidioides immitis found in Washington State soil associated with recent human infection. Clin Infect Dis 2015;60:e1-3. http://dx.doi.org/10.1093/cid/ciu681

2. CDC. Increase in reported coccidioidomycosis-United States, 19982011. MMWR Morb Mortal Wkly Rep 2013;62:217-21.

\section{Cryptosporidiosis}

Approximately $95 \%$ of human cryptosporidiosis is caused by the numerous Cryptosporidium parvum and Cryptosporidium hominis subtypes. Although cryptosporidiosis affects persons of all age groups, cases are most frequently reported in children aged 1-4 years (1). A substantial increase in transmission of Cryptosporidium occurs during summer, coinciding with increased use of recreational water, a well-established risk factor for cryptosporidiosis. Cryptosporidium has emerged as the leading cause of nationally notified recreational waterassociated outbreaks and waterborne disease outbreaks overall (2). Transmission through recreational water is facilitated by the substantial number (up to $10^{8}-10^{9}$ ) of immediately infectious Cryptosporidium oocysts that can be shed in a single bowel movement (3), the extended time (days to weeks) that oocysts can be shed (4), the low ( $\leq 10$ oocysts) infectious dose (5), and the extreme tolerance of Cryptosporidium oocysts to chlorine (6). In 2014, the increased reporting observed after 2004 continued. In addition, the proportion of probable cases has increased to $36 \%$ of all reported cases, primarily because of changes in the 2011 and 2012 national case definitions.

Conventional diagnostics (e.g., microscopy and immunoassays) cannot discriminate among the Cryptosporidium species and their subtypes. CDC has launched CryptoNet, a molecularbased surveillance system that will integrate traditional and molecular data to help elucidate Cryptosporidium transmission pathways and thus the epidemiology of cryptosporidiosis in the United States. CryptoNet has successfully differentiated clusters of illness caused by different Cryptosporidium species and detected outbreaks caused by rare subtypes. Additional information about CryptoNet is available at http://www.cdc. gov/parasites/crypto/cryptonet.html.

To reduce the burden of cryptosporidiosis associated with recreational water, enhanced prevention measures are needed. In the United States, public health codes for public aquatic facilities are written, enacted, implemented, and enforced by state or local officials; no federal agency regulates the design, construction, operation, and maintenance of these venues. To provide support to state and local jurisdictions, CDC led the development and revision of the Model Aquatic Health Code (MAHC) (http://www.cdc.gov/mahc/editions/current. html). This guidance document integrates the latest science and best practices with specific code language and explanatory materials covering the design, construction, operation, and maintenance of public swimming pools, hot tubs/spas, and other aquatic venues. The MAHC is updated every 2 years through an all-stakeholder-driven process via the Council for the Model Aquatic Health Code (www.cmahc.org/index.php) to ensure its continued relevance and to respond to the latest scientific data and aquatics sector innovations.

1. Painter JE, Hlavsa MC, Collier SA, Xiao L, Yoder JS. Cryptosporidiosis surveillance-United States, 2011-2012. MMWR Suppl 2015;64(No. SS-3).

2. Hlavsa MC, Roberts VA, Kahler AM, et al. Outbreaks of illness associated with recreational water-United States, 2011-2012. MMWR Morb Mortal Wkly Rep 2015;64:668-72.

3. Goodgame RW, Genta RM, White AC, Chappell CL. Intensity of infection in AIDS-associated cryptosporidiosis. J Infect Dis 1993;167:704-9. http://dx.doi.org/10.1093/infdis/167.3.704

4. Chappell CL, Okhuysen PC, Sterling CR, DuPont HL. Cryptosporidium parvum: intensity of infection and oocyst excretion patterns in healthy volunteers. J Infect Dis 1996;173:232-6. http://dx.doi.org/10.1093/ infdis/173.1.232

5. Chappell CL, Okhuysen PC, Langer-Curry R, et al. Cryptosporidium hominis: experimental challenge of healthy adults. Am J Trop Med Hyg 2006;75:851-7.

6. Murphy JL, Arrowood MJ, Lu X, Hlavsa MC, Beach MJ, Hill VR. Effect of cyanuric acid on the inactivation of Cryptosporidium parvum under hyperchlorination conditions. Environ Sci Technol 2015;49:7348-55. http://dx.doi.org/10.1021/acs.est.5b00962 


\section{Cyclosporiasis}

Of the 398 cyclosporiasis cases reported in 2014, a total of 275 (69\%) were domestically acquired (i.e., they occurred in persons with no known history of travel outside the United States and Canada during the 14-day incubation period), 77 (19\%) were associated with international travel, and 46 (12\%) occurred in persons for whom the travel status was unknown or missing. Of the domestically acquired cases, 244 (89\%) occurred in persons with onset of illness during May-August. Clusters of cases were identified in Michigan (June onset dates), Texas (June-July onsets), and South Carolina (July onsets) (1). In Michigan, a cluster of 14 cases identified among attendees of a conference included residents of Michigan and six other states. In Texas, 26 cluster-associated cases occurred among patrons of five different local Mexican-style restaurants. In South Carolina, one temporospatial cluster of 13 cases was investigated, although the exact location(s) of exposure was not identified. A vehicle of infection (i.e., fresh cilantro imported from Mexico) was implicated only for the 26 cluster-associated cases in Texas, marking the second consecutive year in which fresh cilantro from Mexico was implicated as the vehicle of infection for at least some of the reported cyclosporiasis cases in Texas. The vehicle(s) of infection was not identified for the remaining 218 ( $89 \%$ of 244$)$ domestically acquired cases with onsets during May-August 2014. No molecular subtyping methods are available that could facilitate linking cases of cyclosporiasis to each other and to particular vehicles and sources of infection.

1. CDC. U.S. foodborne outbreaks of cyclosporiasis-2000-2014. Atlanta, GA: US Department of Health and Human Services, CDC; 2014.

\section{Dengue}

Dengue is an acute febrile illness characterized by myalgia, headache, leukopenia, and minor bleeding manifestations (1). Patients with severe dengue experience plasma leakage resulting in fluid accumulation, hemorrhage, and/or major organ impairment (e.g., liver failure, myocarditis, and impaired consciousness). Dengue is endemic throughout much of the tropics and subtropics, where an estimated 50-100 million cases and 9,200 deaths occur annually (2). With proper clinical management, the case-fatality rate of hospitalized dengue patients can be $<0.5 \%$ (3). Efforts to improve outcomes among persons with dengue include an online clinical education course developed by CDC (http://www.cdc.gov/dengue/training/ cme.html).

In 2014, a total 680 laboratory-positive, travel-associated dengue cases were reported from 44 of the 50 states, two of the five territories, and the District of Columbia. Most (65\%) persons with travel-associated dengue had a history of travel to the Caribbean or Americas, where chikungunya had recently emerged. Because dengue and chikungunya often have a similar clinical presentation, the increase in reported dengue cases compared to previous years, when dengue was not epidemic in the region, might be attributable to increased diagnostic testing to differentiate between these diseases among patients with acute febrile illness. The states with the most travel-associated dengue cases reported were California (130), Arizona (97), and Florida and New Jersey (84 each). Concomitant with a dengue epidemic in northern Mexico, an outbreak of travel-associated dengue occurred in Arizona, and all reported case-patients had recently traveled to Mexico; enhanced surveillance revealed no locally acquired cases (4). Florida reported seven locally acquired dengue cases. In the dengue-endemic Caribbean territories of Puerto Rico and the U.S. Virgin Island, reports of laboratory-positive dengue cases were substantially lower than in previous years (525 and 19 cases, respectively). No cases of dengue hemorrhagic fever were reported in 2014 in travelers or residents of U.S. territories.

1. World Health Organization. Dengue: guidelines for diagnosis, treatment, prevention and control. Geneva, Switzerland: World Health Organization; 2009.

2. Stanaway JD, Shepard DS, Undurrage EA, et al. The global burden of dengue: an analysis from the Global Burden of Disease Study 2013. Lancet Infect Dis 2016;16:712-23.

3. Lam PK, Tam DT, Diet TV, et al. Clinical characteristics of Dengue shock syndrome in Vietnamese children: a 10-year prospective study in a single hospital. Clin Infect Dis 2013;57:1577-86. http://dx.doi.org/10.1093/ $\mathrm{cid} / \mathrm{cit} 594$

4. Jones JM, Lopez B, Adams L, et al. Binational dengue outbreak along the United States-Mexico border-Yuma County, Arizona, and Sonora, Mexico, 2014. MMWR Morb Mortal Wkly Rep 2016;65:495-9. http:// dx.doi.org/10.15585/mmwr.mm6519a3

\section{Diphtheria}

During 2014, a nonfatal case of diphtheria caused by nontoxigenic Corynebacterium diphtheriae was reported to CDC. The case occurred in a 17 -year-old white female resident of Ohio. The patient was fully vaccinated. No other family member or close contact was ill.

\section{Giardiasis}

Giardiasis is the most common enteric parasitic infection in the United States, infecting an estimated 1.2 million persons annually (1). Symptomatology is variable, but giardiasis is normally characterized by diarrhea, abdominal cramps, bloating, weight loss, and malabsorption; extraintestinal symptoms are possible (2). Infected persons can shed Giardia for several weeks, and recent studies indicate a potential for 
chronic sequelae from giardiasis (3). Giardia is endemic worldwide, including in the United States, and is the most commonly diagnosed pathogen among travelers returning to the United States from other countries (4). Giardia is commonly detected in internationally adopted children screened in the United States; often, these children do not have gastrointestinal symptoms (5). In 2014, the reported incidence of giardiasis appeared to decrease compared with 2013, which could reflect changes in reporting practices or changes in the actual occurrence of giardiasis.

Giardia is transmitted through the fecal-oral route with the ingestion of environmentally stable Giardia cysts. Most information on giardiasis transmission is from outbreak investigations; 242 giardiasis outbreaks reported to CDC for 1971-2011 resulted from waterborne (74.8\%), foodborne (15.7\%), person-to-person (2.5\%) and animal contact (1.2\%) transmission (6). On the basis of outbreak trends, investigators identified groundwater and distribution system vulnerabilities in drinking water systems, inadequate pool disinfection, fruit and vegetable contamination, and poor food handler hygiene as possible targets for giardiasis prevention measures. However, the majority of reported giardiasis cases are not linked to known outbreaks. Among reported cases, $<2 \%$ are documented as outbreak-associated (7). An ecological study of sporadic giardiasis in the United States indicated that high county-level reliance on private wells was associated with higher giardiasis rates (8). Prospective epidemiologic studies and continued outbreak and case surveillance are needed to understand transmission pathways and to identify effective public health prevention measures.

Population studies of Giardia seroprevalence would contribute substantially to understanding the prevalence of giardiasis in the United States (9). Enhanced genotyping methods would increase knowledge of the molecular epidemiology of Giardia, including elucidating speciesspecific subassemblages (10). Application of these tools to epidemiologic studies and surveillance has the potential to improve understanding of giardiasis risk factors, enable researchers to identify outbreaks by linking cases currently classified as sporadic infections, and provide risk factor information needed to inform prevention strategies.

1. Scallan E, Hoekstra RM, Angulo FJ, et al. Foodborne illness acquired in the United States-major pathogens. Emerg Infect Dis 2011;17:7-15. http://dx.doi.org/10.3201/eid1701.P11101

2. Cantey PT, Roy S, Lee B, et al. Study of nonoutbreak giardiasis: novel findings and implications for research. Am J Med 2011;124:1175.e1-8. http://dx.doi.org/10.1016/j.amjmed.2011.06.012

3. Hanevik K, Wensaas KA, Rortveit G, Eide GE, Mørch K, Langeland N. Irritable bowel syndrome and chronic fatigue 6 years after giardia infection: a controlled prospective cohort study. Clin Infect Dis 2014;59:1394-400. http://dx.doi.org/10.1093/cid/ciu629
4. Harvey K, Esposito DH, Han P, et al. Surveillance for travel-related disease-GeoSentinel Surveillance System, United States, 1997-2011. MMWR Surveill Summ 2013;62(No. SS-9).

5. Staat MA, Rice M, Donauer S, et al. Intestinal parasite screening in internationally adopted children: importance of multiple stool specimens. Pediatrics 2011;128:e613-22.

6. Adam EA, Yoder JS, Gould H, Hlavsa MC. Giardiasis outbreaks in the United States, 1971-2011. Epidemiol Infect 2016. http://www.ncbi. nlm.nih.gov/pubmed/26750152

7. Schnell K, Collier S, Derado G, Yoder J, Gargano JW. Giardiasis in the United States - an epidemiologic and geospatial analysis of countylevel drinking water and sanitation data, 1993-2010. J Water Health 2016;14:267-79.

8. Yoder JS, Gargano JW, Wallace RM, Beach MJ Giardiasis surveillanceUnited States, 2009-2010. MMWR Surveill Summ 2012;61(No. SS-5).

9. Priest JW, Moss DM, Visvesvara GS, Jones CC, Li A, Isaac-Renton JL. Multiplex assay detection of immunoglobulin $\mathrm{G}$ antibodies that recognize Giardia intestinalis and Cryptosporidium parvum antigens. Clin Vaccine Immunol 2010;17:1695-707. http://dx.doi.org/10.1128/CVI.00160-10

10. Feng Y, Xiao L. Zoonotic potential and molecular epidemiology of Giardia species and giardiasis. Clin Microbiol Rev 2011;24:110-40. http://dx.doi.org/10.1128/CMR.00033-10

\section{Gonorrhea}

Following a historically low rate in 2009 (98.1 cases per 100,000 population), the national rate of reported gonorrhea cases increased $12.8 \%$ to 110.7 cases per 100,000 population in $2014^{*}(1)$. The rate among men steadily increased during this period, including a $10.5 \%$ increase during 2013-2014; the rate among women decreased $0.4 \%$ during 2013-2014. The increase among men, coinciding with the decrease among women, suggests increased transmission and/or or increased case detection, including expanded extragenital gonorrhea screening, among gay, bisexual, and other men who have sex with men. As in previous years, the highest rates of gonorrhea were among persons aged 15-24 years, among non-Hispanic blacks, and in the South. In 2014, the gonorrhea rate among non-Hispanic blacks was 10.6 times the rate among nonHispanic whites. Although the highest rate overall was in the South, including a 3.1\% increase during 2013-2014, the rate of reported gonorrhea cases increased by $22.2 \%$ in the West during the same time.

Treatment for gonorrhea has been complicated by the repeated acquisition of antimicrobial resistance by Neisseria gonorrhoeae. The emergence of fluoroquinolone resistance during 2000-2007 and subsequent declining cefixime susceptibility (2006-2011) resulted in changes in the CDC treatment guidelines in 2007, 2010, and 2012. The only CDC-recommended treatment regimen for gonorrhea is dual therapy with intramuscular ceftriaxone and oral azithromycin (2). In CDC's sentinel surveillance system (Gonococcal Isolate

\footnotetext{
* Rates for 2014 were calculated using the 2013 population estimates and differ from 2014 rates presented in the figures and table 7 (calculated using 2014 population estimates).
} 
Surveillance Project), the percentage of isolates with reduced cefixime susceptibility decreased from $1.4 \%$ in 2011 to $0.4 \%$ in 2013 , and then increased to $0.8 \%$ in 2014 . During this time, the percentage of isolates with elevated ceftriaxone minimum inhibitory concentrations (MICs) ranged from $0.05 \%$ (2013) to $0.4 \%$ (2011). During 2013-2014, the percentage with elevated azithromycin MICs increased from $0.6 \%$ to $2.5 \%$ (1).

1. CDC. Sexually transmitted disease surveillance 2014. Atlanta, GA: US Department of Health and Human Services, CDC; 2015.

2. CDC. Sexually transmitted diseases treatment guidelines, 2015. MMWR Recomm Rep 2015;64(No. RR-3).

\section{Hansen's Disease (Leprosy)}

Hansen's Disease (HD) (i.e., leprosy) is a chronic infectious disease caused by the obligate intracellular bacterium Mycobacterium leprae. Growing optimally at $27^{\circ}-30^{\circ} \mathrm{C}\left(80.6^{\circ}-86.0^{\circ} \mathrm{F}\right), \mathrm{HD}$ primarily affects the skin and superficial peripheral nerves, most notably the posterior tibial and lateral popliteal nerves of the lower leg and foot, the ulnar, median, and radial nerves of the forearm and hand, and the facial nerve (1). HD is highly responsive to treatment but requires a prolonged multidrug therapy of $1-2$ years of dapsone, rifampin, and clofazamine to result in cure (2). However, untreated disease can result in sensory and motor neuropathy, with eventual permanent disability of the eyes, hands, and feet (3).

An average of $89 \mathrm{HD}$ cases have been reported to CDC per year since 2000, with a low of 66 in 2006 and a high of 105 in 2004; not all states list HD as a reportable disease, which might account for the higher numbers reported annually by the National Hansen's Disease Programs (4). By race, white and Asian/Pacific Islanders accounted for the majority of new reported cases (36 [54\%] of 67 cases and 24 [36\%] of 67 cases, respectively). Similar to 2013 , the majority of new cases in 2014 were reported from Texas (19 [22\%] of 88), Hawaii (14 [16\%] of 88 ), and New York City and Florida (10 [11\%] of 88 each). In addition to the 88 cases reported in the United States, 13 cases were reported from Guam and two from Puerto Rico.

1. Eichelmann K, González González SE, Salas-Alanis JC, Ocampo-Candiani J. Leprosy. An update: definition, pathogenesis, classification, diagnosis, and treatment. Actas Dermosifiliogr 2013;104:554-63. http://dx.doi. org/10.1016/j.adengl.2012.03.028

2. Worobec SM. Current approaches and future directions in the treatment of leprosy. Res Rep Trop Med 2012;3:79-91. http://dx.doi.org/10.2147/ RRTM.S27395

3. Walker SL, Lockwood DNJ. Leprosy. Clin Dermatol 2007;25:165-72. http://dx.doi.org/10.1016/j.clindermatol.2006.05.012

4. Hansen's Disease Data \& Statistics. Washington, DC: US Department of Health and Human Services; 2015. http://www.hrsa.gov/hansensdisease/ dataandstatistics.html

\section{Hantavirus Pulmonary Syndrome}

Hantavirus pulmonary syndrome (HPS), a severe and sometimes fatal pulmonary disease resembling acute respiratory distress syndrome, is caused by hantavirus infection. Hantaviruses are transmitted by inhalation or direct contact with virus-containing particles or through direct contact with rodents who harbor the virus, such as the deer mouse (Peromyscus maniculatus). Most HPS cases occur in the western United States $(1,2)$. In 2014, a total of $34^{*}$ cases of HPS occurred in 13 states, of which $33(97 \%)$ occurred in western states. Median age of patients was 38 years (range: 5-84). The 2014 case fatality rate was $38 \%$, similar to previous reports.

Although HPS is a rare disease in the United States, it is associated with severe illness and high rates of death. Persons should avoid contact with deer mice or their droppings and use personal protective equipment when cleaning rodent infested environments.

*Although 32 cases were reported in table 1, two cases were subsequently added.

1. MacNeil A, Ksiazek TG, Rollin PE. Hantavirus pulmonary syndrome, United States, 1993-2009. Emerg Infect Dis 2011;17:1195-201.

2. Knust B, Rollin PE. Twenty-year summary of surveillance for human hantavirus infections, United States. Emerg Infect Dis 2013;19:1934-7. http://dx.doi.org/10.3201/eid1912.131217

\section{Hemolytic Uremic Syndrome, Postdiarrheal}

Hemolytic uremic syndrome (HUS) is characterized by the triad of hemolytic anemia, thrombocytopenia, and renal insufficiency. The most common etiology of postdiarrheal HUS in the United States is infection with Shiga toxinproducing Escherichia coli (STEC), principally STEC O157:H7 $(1,2)$. Children aged $<5$ years progress to HUS more often than all other persons infected with STEC O157:H7 (15.3\% vs. 6.3\%) (3). In 2014, as in previous years of surveillance, the age group with the most reported cases was children aged $1-4$ years (117 of 250 cases).

1. Banatvala N, Griffin PM, Greene KD, et al. The United States National Prospective Hemolytic Uremic Syndrome Study: microbiologic, serologic, clinical, and epidemiologic findings. J Infect Dis 2001;183:1063-70. http://dx.doi.org/10.1086/319269

2. Mody RK, Luna-Gierke RE, Jones TF, et al. Infections in pediatric postdiarrheal hemolytic uremic syndrome: factors associated with identifying shiga toxin-producing Escherichia coli. Arch Pediatr Adolesc Med 2012;166:902-9. http://dx.doi.org/10.1001/archpediatrics.2012.471

3. Gould LH, Demma L, Jones TF, et al. Hemolytic uremic syndrome and death in persons with Escherichia coli O157:H7 infection, foodborne diseases active surveillance network sites, 2000-2006. Clin Infect Dis 2009;49:1480-5. http://dx.doi.org/10.1086/644621 


\section{Human Immunodeficiency Virus Infections}

CDC requires states to report Human Immunodeficiency Virus Infections (HIV) case data through the enhanced HIV/ AIDS Reporting System (eHARS), which is a browser-based system deployed at 54 state/local and territorial public health departments in the United States. HIV surveillance data are not reported through NNDSS. De-identified data are transmitted monthly from health departments through the secure access management system (SAMS) directly to CDC's Division of HIV/AIDS Prevention, National Center for HIV/AIDS, Viral Hepatitis, STD, and TB Prevention, and are incorporated into the National HIV Surveillance System database.

As of April 2008, all 50 states, the District of Columbia, and six U.S. dependent areas required confidential namebased reporting for HIV infection, in addition to reporting persons whose disease has been classified as stage 3 (acquired immunodeficiency syndrome [AIDS]). In 2008, CDC published a revised surveillance case definition for HIV infection that includes AIDS and incorporates the HIV infection classification (1). Laboratory-confirmed evidence of HIV infection is required to meet the surveillance case definition for HIV infection, including stage 3 (AIDS).

In 2014, the HIV surveillance case definition was revised to adapt to changes in diagnostic criteria used by laboratories and clinicians (2). The laboratory criteria for defining a confirmed case of HIV infection were changed to accommodate multitest algorithms that do not include previously required tests (e.g., Western blot). New to the case definition is the inclusion of criteria for differentiating HIV-1 and HIV-2 infections and for recognizing early HIV infection (stage 0), during which viral loads might be high enough and CD4 T-lymphocyte counts low enough to be confused with stage 3 (AIDS). In addition, the revised definition consolidates the staging systems for adults/adolescents and children, simplifies surveillance criteria for opportunistic illnesses indicative of stage 3, and incorporates revisions of clinical criteria (i.e., medical record documentation) for reporting diagnoses without laboratory evidence. Because retroactive implementation of some features (e.g., the new staging system) of the 2014 case definition would be impractical, for this report, cases diagnosed before 2014 were classified according to the 2008 HIV case definition and cases diagnosed in 2014 were classified according to the 2014 HIV case definition.

A total of 35,606 cases of HIV infection were diagnosed in the United States during 2014 and reported to CDC as of December 2014. Blacks had the highest rate of diagnoses of HIV infection of all racial/ethnic groups (40.1 per 100,000 population) and accounted for $44.5 \%$ of diagnoses in 2014 .
Although HIV affects persons in all age groups, cases were most frequently diagnosed in adults aged 25-39 years. Areas with the highest rates $(\geq 15.0)$ of diagnoses during 2014 were the District of Columbia, Florida, Louisiana, Mississippi, New York, South Carolina, and the U.S. Virgin Islands.

1. Schneider E, Whitmore S, Glynn KM, Dominguez K, Mitsch A, McKenna MT. Revised surveillance case definitions for HIV infection among adults, adolescents, and children aged $<18$ months and for HIV infection and AIDS among children aged 18 months to $<13$ years-United States, 2008. MMWR Recomm Rep 2008;57(No. RR-10).

2. CDC. Revised surveillance case definition for HIV infection-United States, 2014. MMWR Recomm Rep 2014;63(No. RR-3).

\section{Influenza-Associated Pediatric Mortality}

In 2004, the Council of State and Territorial Epidemiologists added influenza-associated pediatric mortality to the list of conditions reportable to the National Notifiable Diseases Surveillance System (1). A pediatric influenza-associated death is defined for surveillance purposes as a death resulting from a clinically compatible illness that was confirmed to be influenza by an appropriate laboratory or rapid diagnostic test in a person aged $<18$ years. From December 29, 2013 to January 3, $2015^{*}$, a total of 141 influenza-associated pediatric deaths were reported to CDC from 34 states and New York City.

Of the 141 influenza-associated pediatric deaths reported to CDC during 2014, four deaths occurred during the 2008-09 influenza season, six deaths during the 2009-10 influenza season, two deaths during the 2011-12 influenza season, 103 during the 2013-14 influenza season, and 26 during the 2014-15 influenza season. An influenza season spans the time period between $M M W R$ week 40 of a calendar year to $M M W R$ week 39 of the following year. A total of 117 (83\%) cases were associated with influenza A viruses, 20 (14\%) with influenza B viruses, three $(2.1 \%)$ with an influenza virus for which the type was not determined, and one $(0.7 \%)$ death was associated with influenza A virus and influenza B virus co-infection. Of 117 influenza A viruses, subtype was determined for 70 (60\%); 52 were influenza A (H1N1)pdm09 viruses and 18 were influenza $\mathrm{A}(\mathrm{H} 3 \mathrm{~N} 2)$ viruses.

Among the 141 deaths reported in 2014, a total of 18 (13\%) occurred among children aged $<6$ months, 46 (33\%) among those aged 6-59 months, 43 (31\%) among those aged 5-11 years, and 34 (24\%) among those aged $12-17$ years; the median age at the time of death was 6.1 years (range: 3 days-17 years). The median age in 2014 is similar to previous influenza seasons during nonpandemic periods, but

\footnotetext{
*For 2014, only influenza-associated pediatric deaths that were reported during $M M W R$ week 1 through $M M W R$ week 53 (December 29, 2013-January 3, 2015) are included in this summary.
} 
is lower than the median age of deaths observed during the 2009 pandemic.

Information on the location of death was available for 131 (93\%) of the 141 children: 81 (62\%) children died after being admitted to the hospital ( 73 were admitted to the intensive care unit), 30 (23\%) died in the emergency department, and 20 (15\%) died outside the hospital. Information on pre-existing medical conditions was reported for 136 (96\%) children: 73 (54\%) children had one or more underlying medical condition known to confer increased risk for complications from influenza (2). The most common group of underlying conditions was neurologic disorders (e.g., moderate to severe developmental delay, seizure disorders, cerebral palsy, mitochondrial disorders, neuromuscular disorders, and neurologic conditions), which was reported for 48 (35.3\%) of 136 children. Eleven (8.1\%) of 136 children had cardiac disease or congenital heart disease, 19 (14\%) had chromosomal abnormalities and/or genetic syndromes, and 33 (24\%) had a chronic pulmonary condition (e.g., asthma, cystic fibrosis, or other chronic pulmonary disease).

Among the 141 deaths in children, 69 children had specimens collected for bacterial culture from normally sterile sites. Of these, $24(35 \%)$ had positive cultures, and two $(8.3 \%)$ of the 24 were positive for more than one pathogen. Staphylococcus aureus was detected in five (21\%) of 24 positive cultures; three were methicillin-resistant, and for two specimens methicillinsensitivity testing was not done. Three cultures (13\%) were positive for Streptococcus pneumoniae, six (25\%) were positive for Group A Streptococcus, three (13\%) were positive for Pseudomonas aeruginosa, and two (8.3\%) were positive for Escherichia coli. Other bacterial pathogens identified included one each with Haemophilus influenzae, Klebsiella pneumoniae, and Streptococcus species.

Of 93 children aged $\geq 6$ months at the time of illness onset for whom seasonal vaccination status was known, 20 (22\%) had been vaccinated against influenza as recommended by the Advisory Committee on Immunization Practices (2,3). Twenty-three children were aged $<6$ months at the time of illness onset and ineligible for vaccination.

The number of influenza-associated pediatric deaths reported during 2014 was higher than that in nine of the previous 10 seasons, excluding the 2009 influenza A (H1N1)pdm09 pandemic. Influenza seasons typically span portions of two calendar years and can vary widely in terms of severity and timing of peak activity, thus affecting the number of deaths reported in a calendar year. The 2014-15 influenza season was moderately severe and peaked in late December 2014 (4). Continued surveillance for influenza-associated mortality is important to monitor the effects of seasonal and novel influenza, factors contributing to severe influenza-associated disease, and the influence of interventions among children.
1. Council of State and Territorial Epidemiologists. Influenza-associated pediatric mortality. Position statement 04-ID-04. http://c.ymcdn.com/ sites/www.cste.org/resource/resmgr/PS/04-ID-04-FINAL.pdf

2. Grohskopf LA, Olsen SJ, Sokolow LZ, et al. Prevention and control of seasonal influenza with vaccines: Recommendations of the Advisory Committee on Immunization Practices-United States, 2014-2015. MMWR Morb Mortal Wkly Rep 2014;63:691-7.

3. Advisory Committee on Immunization Practices. Prevention and control of influenza with vaccines: interim recommendations of the Advisory Committee on Immunization Practices (ACIP), 2013. MMWR Morb Mortal Wkly Rep 2013;62:356.

4. Appiah GD, Blanton L, D’Mello T, et al. Influenza activity-United States, 2014-15 season and composition of the 2015-16 influenza vaccine. MMWR Morb Mortal Wkly Rep 2015;64:583-90.

\section{Leptospirosis}

Leptospirosis is a zoonotic disease caused by bacteria of the genus Leptospira. Infection in humans occurs through direct or indirect contact with the urine of infected host animals including rodents $(1,2)$, livestock (3), dogs (4), and many wildlife species. Initial signs and symptoms might mimic certain other febrile illnesses, making recognition difficult (5). Some cases of leptospirosis progress to severe, potentially fatal, disease with signs of multiorgan involvement that can include aseptic meningitis, jaundice, renal failure, pulmonary involvement, and hemorrhage $(1,2)$.

Exposure risks for leptospirosis include recreational water activities (2,6), such as wading, swimming, rafting and kayaking, especially after heavy rainfall; contact with floodwaters; occupational exposures related to farming $(\sigma)$ and contact with host animals, such as occurs with slaughterhouse workers and veterinarians $(2,7)$; and living in areas with rodent infestation (8). Cases of leptospirosis in the United States also have been linked to adventure racing and multisport events $(9,10)$ and with travel to countries where leptospirosis is endemic.

The emergence of new risk groups; the lack of dynamic data on incidence, distribution, and risk factors; and the likely underestimation of disease incidence led to the reinstatement of leptospirosis to the list of nationally notifiable diseases by the Council of State and Territorial Epidemiologists in 2013. CDC officially began receiving case notifications through the National Notifiable Diseases Surveillance System (NNDSS) in January 2014. Leptospirosis is reportable in 46 jurisdictions, states, and territories.

In 2014, a total of 107 cases of leptospirosis were reported to NNDSS from 11 states and one territory. Sixty-nine (64\%) cases were from Puerto Rico and 23 (21\%) were from Hawaii. In the 50 states and the District of Columbia, of 38 total cases, $30(79 \%)$ were male, a trend identified in previous reports $(6)$. Of 35 cases with reported age, 31 (89\%) were aged 15-64 years. After 19 years without standardized reporting of leptospirosis cases, increasing the awareness of leptospirosis among health 
care providers and improving the detection and reporting of leptospirosis cases is essential for improving understanding of the disease's epidemiology in the United States.

1. Bharti AR, Nally JE, Ricaldi JN, et al. Leptospirosis: a zoonotic disease of global importance. Lancet Infect Dis 2003;3:757-71. http://dx.doi. org/10.1016/S1473-3099(03)00830-2

2. Levett PN. Leptospirosis. Clin Microbiol Rev 2001;14:296-326. http:// dx.doi.org/10.1128/CMR.14.2.296-326.2001

3. Talpada MD, Garvey N, Sprowls R, Eugster AK, Vinetz JM. Prevalence of leptospiral infection in Texas cattle: implications for transmission to humans. Vector Borne Zoonotic Dis 2003;3:141-7. http://dx.doi. org/10.1089/153036603768395843

4. Ward MP, Glickman LT, Guptill LE. Prevalence of and risk factors for leptospirosis among dogs in the United States and Canada: 677 cases (1970-1998). J Am Vet Med Assoc 2002;220:53-8. http://dx.doi. org/10.2460/javma.2002.220.53

5. Lo Y-C, Kintziger KW, Carson HJ, et al. Severe leptospirosis similar to pandemic (H1N1) 2009, Florida and Missouri, USA. Emerg Infect Dis 2011;17:1145-6. http://dx.doi.org/10.3201/eid/1706.100980

6. Katz AR, Buchholz AE, Hinson K, Park SY, Effler PV. Leptospirosis in Hawaii, USA, 1999-2008. Emerg Infect Dis 2011;17:221-6. http:// dx.doi.org/10.3201/eid1702.101109

7. Guerra MA. Leptospirosis. J Am Vet Med Assoc 2009;234:472-8,30.

8. Vinetz JM, Glass GE, Flexner CE, Mueller P, Kaslow DC. Sporadic urban leptospirosis. Ann Intern Med 1996;125:794-8. http://dx.doi. org/10.7326/0003-4819-125-10-199611150-00002

9. Stern EJ, Galloway R, Shadomy SV, et al. Outbreak of leptospirosis among Adventure Race participants in Florida, 2005. Clin Infect Dis 2010;50:843-9. http://dx.doi.org/10.1086/650578

10. Sejvar J, Bancroft E, Winthrop K, et al. Leptospirosis in "Eco-Challenge" athletes, Malaysian Borneo, 2000. Emerg Infect Dis 2003;9:702-7. http://dx.doi.org/10.3201/eid0906.020751

\section{Listeriosis}

Listeria monocytogenes infection (listeriosis) is rare but can cause severe invasive disease (e.g., bacteremia and meningitis). Listeriosis is predominately acquired through contaminated food and occurs most frequently among older adults, persons with certain immunocompromising conditions, and pregnant women and their newborns. Pregnancy-associated listeriosis is usually a relatively mild illness for women, but can result in fetal loss or severe neonatal disease.

Listeriosis has been nationally notifiable since 2000. In 2014, the incidence of listeriosis reported to the National Notifiable Diseases Surveillance System (NNDSS) was 0.24 infections per 100,000 population. Progress toward the 2020 national target of 0.2 infections (1) is measured through the Foodborne Diseases Active Surveillance Network (FoodNet), which conducts active, population-based surveillance for listeriosis in 10 U.S. states. FoodNet reported a preliminary annual incidence of Listeria monocytogenes in 2014 of 0.24 infections, the same rate reported to NNDSS (2).

The Listeria Initiative is an enhanced surveillance system designed to aid in the rapid investigation of listeriosis outbreaks by combining molecular subtyping results with epidemiologic data collected by state and local health departments (3). As part of the Listeria Initiative, CDC recommends that all clinical isolates of $L$. monocytogenes be forwarded routinely to a public health laboratory for pulsed-field gel electrophoresis (PFGE) subtyping and that these PFGE subtyping results be submitted to PulseNet, the National Molecular Subtyping Network for Foodborne Disease Surveillance (4); clinical isolates also should be promptly sent to CDC for further characterization. In addition, communicable disease programs are asked to interview all patients with listeriosis promptly using the standard Listeria Initiative questionnaire, which is available in English and Spanish (http://www.cdc.gov/listeria/ surveillance.html).

Beginning in September 2013, whole genome sequencing has been performed on all clinical isolates as part of a project conducted by CDC, state and local health departments, the Food and Drug Administration, the U.S. Department of Agriculture's Food Safety and Inspection Service, the National Institutes of Health, and international partners (5). All isolate sequences are deposited in publicly available databases at the National Center for Biotechnology Information of the National Institutes of Health. The Listeria Initiative has aided in the timely identification and removal of contaminated food during several listeriosis investigations, including a multistate outbreak of 35 illnesses that was linked to commercially produced, prepackaged caramel apples in 2014 (6).

1. US Department of Health and Human Services. Healthy People 2020 objectives. https://www.healthypeople.gov/2020/topics-objectives/topic/ food-safety/objectives?topicId=14

2. Crim SM, Griffin PM, Tauxe R, et al. Preliminary incidence and trends of infection with pathogens transmitted commonly through food-Foodborne Diseases Active Surveillance Network, 10 U.S. sites, 2006-2014. MMWR Morb Mortal Wkly Rep 2015;64:495-9.

3. CDC. National Enteric Disease Surveillance: The Listeria Initiative. Atlanta, Georgia: US Department of Health and Human Services, CDC, 2014. http://www.cdc.gov/listeria/pdf/ListeriaInitiativeOverview_508.pdf

4. CDC. PulseNet. http://www.cdc.gov/pulsenet

5. CDC. AMD projects: Learning from Listeria. http://www.cdc.gov/amd/ project-summaries/listeria.html

6. CDC. Multistate outbreak of listeriosis linked commercially produced, prepackaged caramel apples made from Bidart Bros. apples (final update). http://www.cdc.gov/listeria/outbreaks/caramel-apples-12-14/index.html

\section{Lyme Disease}

In 2014, the number of confirmed Lyme disease cases reported to CDC decreased compared with the number reported in 2013, but was higher compared to the number reported during 2010-2012. On the basis of reports to the National Notifiable Diseases Surveillance System (NNDSS), the geographic distribution of high incidence areas has 
expanded over time (1), with 381 counties reporting an incidence of $\geq 10$ confirmed cases per 100,000 persons in 2014, compared with 324 counties in 2008. In addition, during 2013-2014, CDC and state and county health departments investigated several sudden cardiac deaths associated with Lyme carditis through case series, death certificate analysis, and review of NNDSS surveillance data $(2,3)$. This rare but very serious complication of Lyme disease underscores the importance of reducing exposure to ticks and tick habitat.

1. Kugeler KJ, Farley GM, Forrester JD, Mead PS. Geographic distribution and expansion of human Lyme disease, United States. Emerg Infect Dis 2015;21:1455-7. http://dx.doi.org/10.3201/eid2108.141878

2. CDC. Three sudden cardiac deaths associated with Lyme carditisUnited States, November 2012-July 2013. MMWR Morb Mortal Wkly Rep 2013;62:993-6.

3. Forrester JD, Meiman J, Mullins J, et al. Notes from the field: update on Lyme carditis, groups at high risk, and frequency of associated sudden cardiac death-United States. MMWR Morb Mortal Wkly Rep 2014;63:982-3.

\section{Measles}

Measles was declared eliminated from the United States in 2000. Since then, elimination has been maintained through high population immunity along with adequate disease surveillance and public health response capacity $(1,2)$. Nonetheless, because measles remains endemic in much of the world, importations continue to result in sporadic cases and outbreaks in the United States, which can be costly to control (3). As in the other years since elimination, most measles cases (99\%) were import-associated (4).

A measles outbreak is defined as a chain of transmission involving three or more cases. A total of 23 outbreaks occurred in 2014 , accounting for $81 \%$ of the total cases. There were 63 international importations, the most since 2011, and $43 \%$ of importations originated from the Philippines. The largest outbreak accounted for $57 \%$ of the cases. In each of these outbreaks, transmission occurred after a U.S. resident traveler introduced measles into communities with pockets of persons unvaccinated because of philosophical or religious beliefs. This allowed for spread to occur, mainly in households and community gatherings, before public health interventions could be implemented (CDC, unpublished data, 2014).

The largest outbreak occurred in Ohio, which started when unvaccinated travelers visited the Philippines where a large outbreak of measles was occurring. The travelers returned to Ohio and spread the disease to other unvaccinated persons (89\% unvaccinated, 10\% unknown, and 1\% with 1 dose). This outbreak was the largest outbreak in the United States since 1992.
1. Hutchins SS, Bellini WJ, Coronado V, Jiles R, Wooten K, Deladisma A. Population immunity to measles in the United States, 1999. J Infect Dis 2004;189(Suppl 1):S91-7. http://dx.doi.org/10.1086/377713

2. Papania MJ, Wallace GS, Rota PA, et al. Elimination of endemic measles, rubella, and congenital rubella syndrome from the Western hemisphere: the US experience. JAMA Pediatr 2014;168:148-55. http://dx.doi. org/10.1001/jamapediatrics.2013.4342

3. Parker AA, Staggs W, Dayan GH, et al. Implications of a 2005 measles outbreak in Indiana for sustained elimination of measles in the United States. N Engl J Med 2006;355:447-55. http://dx.doi. org/10.1056/NEJMoa060775

4. Council of State and Territorial Epidemiologists. Revision of measles, rubella, and congenital syndrome case classification as part of elimination goals in the United States. Position statement 2006-ID-16.

\section{Meningococcal Disease}

Neisseria meningitidis is an important cause of bacterial meningitis and sepsis in the United States. In 2014, rates of meningococcal disease continued to be at historic lows in the United States (0.18 cases per 100,000 population). CDC's Advisory Committee on Immunization Practices (ACIP) recommends routine use of quadrivalent (serogroup A, C, W, and $\mathrm{Y}$ ) meningococcal conjugate vaccine in adolescents and others at increased risk for disease (1-3). In 2014, coverage with at least 1 dose of meningococcal conjugate vaccine was $79.3 \%$ among adolescents aged 13-17 years in the United States; however, by state, coverage ranged from $46.0 \%-95.2 \%$, including the District of Columbia (4). Coverage with $\geq 2$ doses of meningococcal conjugate vaccine among adolescents aged 17 years was $28.5 \%(4)$.

Two serogroup B meningococcal vaccines were licensed for use in the United States in 2014 and 2015. Both vaccines are approved for use in persons aged 10-25 years. In 2015, ACIP recommended routine use of serogroup B meningococcal vaccine in certain groups at increased risk for disease (5). A serogroup $B$ meningococcal vaccine series also can be administered to adolescents and young adults aged 16-23 years to provide short-term protection against most strains of serogroup B meningococcal disease. The preferred age for serogroup B meningococcal vaccination is $16-18$ years $(6)$.

1. Cohn AC, MacNeil JR, Clark TA, et al. Prevention and control of meningococcal disease: recommendations of the Advisory Committee on Immunization Practices (ACIP). MMWR Recomm Rep 2013; 62(No.RR-2).

2. Cohn AC, MacNeil JR, Harrison LH, et al. Changes in Neisseria meningitidis disease epidemiology in the United States, 1998-2007: implications for prevention of meningococcal disease. Clin Infect Dis 2010;50:184-91. http://dx.doi.org/10.1086/649209

3. MacNeil JR, Rubin L, McNamara L, Briere EC, Clark TA, Cohn AC. Use of MenACWY-CRM vaccine in children aged 2 through 23 months at increased risk for meningococcal disease: recommendations of the Advisory Committee on Immunization Practices, 2013. MMWR Morb Mortal Wkly Rep 2014;63:527-30. 
4. Reagan-Steiner S, Yankey D, Jeyarajah J, et al. National, regional, state, and selected local area vaccination coverage among adolescents aged 13-17 years-United States, 2014. MMWR Morb Mortal Wkly Rep 2015;64:784-92. http://dx.doi.org/10.15585/mmwr.mm6429a3

5. Folaranmi T, Rubin L, Martin SW, Patel M, MacNeil JR. Use of serogroup $B$ meningococcal (MenB) vaccines in persons aged $\geq 10$ years at increased risk for serogroup $B$ meningococcal disease: recommendations of the Advisory Committee on Immunization Practices (ACIP), 2015. MMWR Morb Mortal Wkly Rep 2015;64:608-12.

6. MacNeil JR, Rubin L, Folaranmi T, Ortega-Sanchez IR, Patel M, Martin SW. Use of serogroup B meningococcal (MenB) vaccines in adolescents and young adults: recommendations of the Advisory Committee on Immunization Practices (ACIP), 2015. MMWR Morb Mortal Wkly Rep 2015;64:1171-6. http://dx.doi.org/10.15585/mmwr.mm6441a3

\section{Mumps}

In 2014, a total of 1,223 cases of mumps were reported in the United States with an overall incidence rate of 0.38 cases per 100,000 persons. Most $(\mathrm{N}=883[72 \%])$ mumps cases reported in the United States during 2014 were from three states (Ohio, Illinois, and Wisconsin) and New York City, all of which experienced university-based outbreaks. Universitybased outbreaks are known to occur despite high 2-dose vaccine coverage (1). Reported median vaccine-effectiveness for mumps vaccine is $78 \%$ for 1 -dose and $88 \%$ for 2 -doses (2). Close and prolonged contact likely facilitates mumps transmission.

1. Dayan GH, Quinlisk MP, Parker AA, et al. Recent resurgence of mumps in the United States. N Engl J Med 2008;358:1580-9. http://dx.doi. org/10.1056/NEJMoa0706589

2. McLean HQ, Fiebelkorn AP, Temte JL, Wallace GS. Prevention of measles, rubella, congenital rubella syndrome, and mumps, 2013: summary recommendations of the Advisory Committee on Immunization Practices (ACIP). MMWR Recomm Rep 2013;62(No. RR-4).

\section{Novel Influenza A Viruses}

In 2007, the Council of State and Territorial Epidemiologists added human infection with a novel influenza $A$ virus to the list of conditions reportable to the National Notifiable Diseases Surveillance System (1). Novel influenza A virus infections are human infections with influenza A viruses that are different from currently circulating human seasonal influenza viruses. These viruses include those that are subtyped as nonhuman in origin and those that cannot be subtyped with standard methods and reagents used for currently circulating influenza viruses.

Influenza viruses that normally circulate in swine are called swine influenza viruses when isolated from swine, but are called variant viruses when isolated from humans. During 2005-2014, all reported novel influenza A human infections in the United States involved variant viruses rather than avianorigin influenza viruses. Although most persons identified with variant influenza virus infection report contact with swine preceding their illness, suggesting swine-to-human spread, limited human-to-human transmission of these viruses has occurred (2). Because the implications of ongoing transmission of these viruses between humans are potentially severe, prompt and thorough investigation of human infections with novel influenza viruses is critical so that risk for infection can be more fully understood and appropriate public health measures can be taken (3).

In 2014, three human infections with novel influenza $A$ viruses were reported from two states (Ohio [two] and Wisconsin [one]) $(4,5)$. All three cases involved infection with an influenza $\mathrm{A}(\mathrm{H} 3 \mathrm{~N} 2)$ variant virus $(\mathrm{H} 3 \mathrm{~N} 2 \mathrm{v})$. The median age of patients was seven years (range: $2-10$ years), and all three were female. Reported symptoms associated with infection were fever $(100 \%)$, cough $(100 \%)$, fatigue $(100 \%)$, shortness of breath $(67 \%)$, muscle aches $(67 \%)$, vomiting or diarrhea $(67 \%)$, and conjunctivitis (33\%); all three cases reported influenza-like illness (e.g. fever $\left(\geq 100^{\circ} \mathrm{F}\left[37.8^{\circ} \mathrm{C}\right]\right.$ with cough and/or sore throat). None had an underlying medical condition known to confer increased risk for complications from influenza ( 6 ). All three patients sought health care for their illness and one was hospitalized; all three fully recovered. All three reported direct contact with (e.g., touching or handling) or proximity to (e.g., walking through an area or coming within 6 feet of) swine in the week preceding illness onset. No likely human-to-human transmission of novel influenza A viruses was identified.

Transmission of variant influenza A viruses to humans usually occurs among persons with direct, unprotected contact with swine or environments where swine are or have been present (e.g., agricultural fairs, farms, and petting zoos). CDC conducts surveillance for human infections with novel influenza A viruses in conjunction with state and local public health laboratories year-round and conducts extensive epidemiologic investigations on each case. Any specimen with results suggestive of the presence of a novel influenza A virus or that cannot be subtyped using standard methods and reagents at a public health laboratory is immediately submitted to CDC for further testing. Surveillance for human infections with novel influenza A viruses is essential, and early identification and investigation of human infections with novel influenza A viruses are critical so that risk for infection can be more fully understood and appropriate public health measures taken.

1. Council of State and Territorial Epidemiologists. Public health reporting and national notification for novel influenza A virus infection. Position statement 13-ID-14. http://c.ymcdn.com/sites/www.cste.org/resource/ resmgr/PS/13-ID-14.pdf

2. Jhung MA, Epperson S, Biggerstaff M, et al. Outbreak of variant influenza A(H3N2) virus in the United States. Clin Infect Dis 2013;57:1703-12. http://dx.doi.org/10.1093/cid/cit649 
3. Richards S, Glazier M, Masterson K, et al. Update: Influenza A (H3N2)v transmission and guidelines - five states, 2011. MMWR Morb Mortal Wkly Rep 2012;60:1741-4.

4. Blanton L, Brammer L, Smith S, et al. Update: influenza activity United States and worldwide, May 18-September 20, 2014. MMWR Morb Mortal Wkly Rep 2014;63:861-4.

5. Rolfes M, Blanton L, Brammer L, et al. Update: influenza activity United States, September 28-December 6, 2014. MMWR Morb Mortal Wkly Rep 2014;63:1189-94.

6. Grohskopf LA, Olsen SJ, Sokolow LZ, et al. Prevention and control of seasonal influenza with vaccines: Recommendations of the Advisory Committee on Immunization Practices-United States, 2014-2015. MMWR Morb Mortal Wkly Rep 2014;63:691-7.

\section{Pertussis}

Reported pertussis cases in the United States increased 15\% from 2013 (incidence: 9.0 per 100,000 population) to 2014 (10.4). Despite the national increase in reporting, a majority of states reported fewer cases in 2014 than in 2013 (32). However, in 2014, California reported the largest number of cases observed $(8,723)$ since its 2010 pertussis epidemic $(7,195)(1)$. Six additional states reported a $\geq 50 \%$ increase in cases (Connecticut, Delaware, Idaho, Maine, Nebraska, and South Dakota). Although the age distribution of reported cases is similar to that reported for 2013, peak incidence has shifted from children aged 10 years in 2013 to those aged 15 years in 2014, likely the effect of waning immunity among aging cohorts of adolescents vaccinated exclusively with acellular pertussis vaccines (2-4). A total of 13 deaths occurred among all age groups; eight of the deaths occurred among infants aged $<1$ year, who account for most pertussis-related deaths reported in the United States. Maternal Tdap vaccination during the third trimester of pregnancy remains the primary recommendation for prevention of pertussis in infants (5).

1. Winter K, Glaser C, Watt J, Harriman K. Pertussis epidemic_California, 2014. MMWR Morb Mortal Wkly Rep 2014;63:1129-32.

2. Misegades LK, Winter K, Harriman K, et al. Association of childhood pertussis with receipt of 5 doses of pertussis vaccine by time since last vaccine dose, California, 2010. JAMA 2012;308:2126-32. http://dx.doi. org/10.1001/jama.2012.14939

3. Tartof SY, Lewis M, Kenyon C, et al. Waning immunity to pertussis following 5 doses of DTaP. Pediatrics 2013;131:e1047-52. http://dx.doi. org/10.1542/peds.2012-1928

4. Acosta AM, DeBolt C, Tasslimi A, et al. Tdap vaccine effectiveness in adolescents during the 2012 Washington State pertussis epidemic. Pediatrics 2015;135:981-9. http://dx.doi.org/10.1542/peds.2014-3358

5. CDC. Updated recommendations for use of tetanus toxoid, reduced diphtheria toxoid, and acellular pertussis vaccine (Tdap) in pregnant women-Advisory Committee on Immunization Practices (ACIP), 2012. MMWR Morb Mortal Wkly Rep 2013;62:131-5.

\section{Plague}

Plague is a highly virulent fleaborne zoonosis caused by Yersinia pestis. A median of eight cases are reported each year in the United States (1). Most human plague infections result from an infectious flea bite; however, domestic animals can become infected and transmit plague to humans. Bubonic and septicemic plague are common clinical forms of plague and are not transmissible to others. In contrast, persons with pneumonic plague can transmit infection to others via infective respiratory droplets (2).

During 2014, an outbreak of pneumonic plague occurred in Colorado involving four patients. All four had exposure to a dog with confirmed pneumonic plague; however, person-toperson transmission between two of these patients could not be excluded (3). This is the first documented transmission from a domestic dog to humans in the United States. Furthermore, this event represents the largest outbreak and the first instance of possible human-to-human transmission in the United States since $1924(1,2)$.

1. Kugeler KJ, Staples JE, Hinckley AF, Gage KL, Mead PS. Epidemiology of human plague in the United States, 1900-2012. Emerg Infect Dis 2015;21:16-22. http://dx.doi.org/10.3201/eid2101.140564

2. Kool JL. Risk of person-to-person transmission of pneumonic plague. Clin Infect Dis 2005;40:1166-72. http://dx.doi.org/10.1086/428617

3. Runfola JK, House J, Miller L, et al. Outbreak of human pneumonic plague with dog-to-human and possible human-to-human transmissionColorado, June-July 2014. MMWR Morb Mortal Wkly Rep 2015;64:429-34.

\section{Q-Fever}

Q fever is a zoonosis caused by the obligate intracellular bacterium Coxiella burnetii. The primary route of exposure is inhalation of aerosolized birth products from livestock (e.g., cows, goats, or sheep). In addition, other routes of exposure, such as ingestion, tick bite, and sexual transmission, are possible. In 2014, a cluster of five suspect $Q$ fever cases in New York was associated with a history of travel to Germany for live cell therapy (injections of cells from the organs or fetuses of nonhuman animals) (1). A case from Canada was also associated with the New York cluster. Health care providers should be aware of medical tourism for this live cell therapy and the associated risks.

1. Robyn MP, Newman AP, Amato M, et al. Q Fever outbreak among travelers to Germany linked to live cell therapy-United States and Canada, 2014. MMWR Morb Mortal Wkly Rep 2015;64:1071-3. http:// dx.doi.org/10.15585/mmwr.mm6438a3 


\section{Rabies}

During 2014, one case of human rabies was reported in the United States. The case was reported from Missouri. The patient presented with neck pain that radiated down the left arm that progressed to left arm numbness and tingling, bilateral upper body tremors, anxiousness, and hallucinations. Because of the unexplained rapidly progressive encephalitis and selfreported hydrophobia, rabies was suspected. CDC antemortem testing confirmed a rabies virus variant associated with the tri-colored bat Perimyotis subflavus. Following diagnosis, life support was withdrawn and the patient died.

During 2014, the number of animals submitted to state and local laboratories for rabies diagnosis $(104,313)$ increased $7.8 \%$ compared with 2013. A total of 5,988 animals were confirmed positive. Increases in the number of animals reported rabid were observed for the following species: sheep/goats (10.0\%), skunks $(9.8 \%)$, cats $(9.2 \%)$, and bats $(9.0 \%)$. The number of reported rabid dogs $(50.8 \%)$, foxes $(10.6 \%)$, cattle $(8.9 \%)$, raccoons $(4.2 \%)$ and horses/mules $(3.3 \%)$ also decreased compared with 2013.

\section{Salmonellosis}

In 2014, the incidence of salmonellosis in the United States was 16.3 laboratory-confirmed infections per 100,000 population, approximately one and a half times the 2020 national health objectives target of 11.4 (1). Data from the Foodborne Diseases Active Surveillance Network (FoodNet), which conducts active surveillance for salmonellosis in 10 U.S. states, are used to measure progress towards Healthy People 2020 objectives. In 2014, FoodNet reported a preliminary annual incidence of Salmonella of 15.5, slightly lower than the rate reported to the National Notifiable Diseases Surveillance System (2). During 2014, as in previous years of surveillance, children aged $<5$ years had the highest reported incidence rates of salmonellosis. Salmonellosis is reported most frequently in late summer and early fall; in 2014, this seasonality was evident, with most reports during July-October.

Accounting for underdiagnosis, Salmonella causes an estimated 1.2 million illnesses annually in the United States; of these, an estimated 1 million are transmitted by food consumed in the United States (3). Salmonella can contaminate a wide range of foods, and different serotypes tend to have different animal reservoirs and food sources, making control challenging. The largest multistate outbreak of Salmonella infections in 2014 (serotypes Infantis, Newport, and Hadar) was traced to live poultry in backyard flocks; other notable outbreaks in 2014 were linked to cucumbers (serotype Newport), bean sprouts (serotype Enteritidis), nut butter (serotype Braenderup), clinical and college and university teaching microbiology laboratories (serotype Typhimurium), organic sprouted chia powder (serotypes Newport, Hartford, and Oranienburg), frozen feeder rodents (serotype Typhimurium), pet bearded dragons (serotypes Cotham and Kisarawe), mechanically separated chicken (serotype Heidelberg), and raw cashew cheese (serotype Stanley) (4).

1. US Department of Health and Human Services. Healthy People 2020 objectives. https://www.healthypeople.gov/2020/topics-objectives/topic/ food-safety/objectives? topicId $=14$

2. CDC. Foodborne Diseases Active Surveillance Network. http://www.cdc. gov/foodnet/data/trends/tables/2013/table2a-b.html\#table-2b

3. Scallan E, Hoekstra RM, Angulo FJ, et al. Foodborne illness acquired in the United States—major pathogens. Emerg Infect Dis 2011;17:7-15. http://dx.doi.org/10.3201/eid1701.P11101

4. CDC. Reports of selected Salmonella outbreak investigations, 2014. http:// www.cdc.gov/salmonella/outbreaks.html

\section{Shiga Toxin-Producing Escherichia coli}

In 2014, the incidence of laboratory-confirmed Shiga toxin-producing Escherichia coli (STEC) infections in the United States was 2.0 cases per 100,000 population. FoodNet, an active, population-based surveillance system for enteric diseases, reported STEC incidence of 2.4 in 2014 (1). As in all previous years of surveillance, the age group with the highest incidence of reported STEC infections was children aged 1-4 years (9.0). In 2014, multistate outbreaks of STEC infection linked to foods included raw clover sprouts (STEC O121) and ground beef (STEC O157:H7) (2).

Public health actions to monitor, prevent, and control STEC infections are based on serogroup characterization. Development of postdiarrheal hemolytic uremic syndrome (HUS), a severe complication of STEC infection, is most strongly associated with STEC O157. Non-O157 STEC, a diverse group that varies in virulence, comprises over 50 other serogroups. Increased use of assays for the detection of Shiga toxins in clinical laboratories in recent years has led to increased reporting of non-O157 STEC infection (3). STEC can produce Shiga toxins (Stx): Stx1, Stx2, or both. In general, strains that produce certain types of Stx 2 are the most virulent (4). Accounting for underdiagnosis, an estimated 96,000 illnesses are caused by STEC O157 and 168,000 illnesses by non-O157 STEC each year $(5,6)$.

Stool specimens from patients with community-acquired diarrhea submitted to clinical laboratories should be tested routinely both by culture for STEC O157 and by an assay that detects Shiga toxins (or the genes that encode them). Detection of Shiga toxin alone is inadequate for clinical management and public health investigation; characterizing STEC isolates by serogroup and by pulsed-field gel electrophoresis pattern is important to detect, investigate, and control outbreaks. 
1. Crim SM, Griffin PM, Tauxe R, et al.. Preliminary incidence and trends of infection with pathogens transmitted commonly through food-Foodborne Diseases Active Surveillance Network, 10 U.S. sites, 2006-2014. MMWR Morb Mortal Wkly Rep 2015;64:495-9.

2. CDC. Reports of selected E. coli outbreak investigations. http://www. cdc.gov/ecoli/outbreaks.html

3. Gould LH, Mody RK, Ong KL, et al. Increased recognition of non-O157 Shiga toxin-producing Escherichia coli infections in the United States during 2000-2010: epidemiologic features and comparison with $E$. coli O157 infections. Foodborne Pathog Dis 2013;10:453-60. http://dx.doi. org/10.1089/fpd.2012.1401

4. Mody RK, Griffin PM. Fecal shedding of Shiga toxin-producing Escherichia coli: what should be done to prevent secondary cases? Clin Infect Dis 2013;56:1141-4. http://dx.doi.org/10.1093/cid/cis1222

5. Heiman KE, Mody RK, Johnson SD, Griffin PM, Gould LH. Escherichia coli O157 Outbreaks in the United States, 2003-2012. Emerg Infect Dis 2015;21:1293-301. http://dx.doi.org/10.3201/eid2108.141364

6. Scallan E, Hoekstra RM, Angulo FJ, et al. Foodborne illness acquired in the United States-major pathogens. Emerg Infect Dis 2011;17:7-15. http://dx.doi.org/10.3201/eid1701.P11101

\section{Shigellosis}

In 2014, the incidence of reported shigellosis in the United States was 6.5 infections per 100,000 population. This is comparable to the incidence of laboratory-confirmed shigellosis reported by FoodNet, an active, population-based surveillance system for enteric diseases, in 2014 (5.8), and is in line with fairly stable incidence rates observed in FoodNet during the previous decade $(1,2)$. In 2014, as in previous years, the highest number of reported cases of shigellosis occurred among children aged $<10$ years. S. sonnei infections account for approximately $75 \%$ of shigellosis in the United States (3). Shigellosis does not demonstrate marked seasonality, likely reflecting the importance of person-to-person transmission.

Accounting for underdiagnoses, Shigella causes an estimated 500,000 illnesses annually in the United States; of these, an estimated 130,000 are transmitted by food consumed in the United States (3). Shigella is often transmitted personto-person, including through sexual contact between men who have sex with men (MSM), and can also be transmitted by contaminated food or by contaminated water used for drinking or recreational purposes (4). Some cases of shigellosis are acquired during international travel $(5,6)$ and have caused multidrug-resistant outbreaks in the United States (7). Childcare-associated outbreaks are common and are often difficult to control (8).

MSM and persons infected with human immunodeficiency virus appear to be at the greatest risk for infection with Shigella with decreased susceptibility to azithromycin $(9,10)$. In 2014 , the majority of isolates known to be resistant to azithromycin harbored mphA or erm B, macrolide resistance genes that are typically plasmid-encoded. For adults with suspected shigellosis, clinicians should obtain sexual histories, collect stool specimens, test for antimicrobial susceptibility, and counsel patients about prevention.

1. Crim SM, Griffin PM, Tauxe R, et al. Preliminary incidence and trends of infection with pathogens transmitted commonly through food - Foodborne Diseases Active Surveillance Network, 10 U.S. sites, 2006-2014. MMWR Morb Mortal Wkly Rep 2015;64:495-9.

2. CDC. Foodborne Diseases Active Surveillance Network—FoodNet 2013 surveillance report. https://www.cdc.gov/foodnet/pdfs/508-compliant2013-foodnet-annual-report.pdf

3. Scallan E, Hoekstra RM, Angulo FJ, et al. Foodborne illness acquired in the United States-major pathogens. Emerg Infect Dis 2011;17:7-15. http://dx.doi.org/10.3201/eid1701.P11101

4. Gupta A, Polyak CS, Bishop RD, Sobel J, Mintz ED. Laboratoryconfirmed shigellosis in the United States, 1989-2002: epidemiologic trends and patterns. Clin Infect Dis 2004;38:1372-7. http://dx.doi. org/10.1086/386326

5. Baker KS, Dallman TJ, Ashton PM, et al. Intercontinental dissemination of azithromycin-resistant shigellosis through sexual transmission: a cross-sectional study. Lancet Infect Dis 2015;15:913-21. http://dx.doi. org/10.1016/S1473-3099(15)00002-X

6. Gray MD, Lampel KA, Strockbine NA, Fernandez RE, Melton-Celsa AR, Maurelli AT. Clinical isolates of Shiga toxin 1a-producing Shigella flexneri with an epidemiological link to recent travel to Hispañiola. Emerg Infect Dis 2014;20:1669-77. http://dx.doi.org/10.3201/ eid2010.140292

7. Bowen A, Hurd J, Hoover C, et al. Importation and domestic transmission of Shigella sonnei resistant to ciprofloxacin - United States, May 2014-February 2015. MMWR Morb Mortal Wkly Rep 2015;64:318-20.

8. Arvelo W, Hinkle CJ, Nguyen TA, et al. Transmission risk factors and treatment of pediatric shigellosis during a large daycare center-associated outbreak of multidrug resistant Shigella sonnei: implications for the management of shigellosis outbreaks among children. Pediatr Infect Dis J 2009;28:976-80. http://dx.doi.org/10.1097/INF.0b013e3181a76eab

9. Bowen A, Grass J, Bicknese A, et al. Elevted risk for antimicrobial drug-resistant Shigella infection among men who have sex with men, United States 2011-2015. Emerg Infect Dis 2016;9. E-pub ahead of print.

10. Bowen A, Eikmeier D, Talley P, et al. Outbreaks of Shigella sonnei infection with decreased susceptibility to azithromycin among men who have sex with men-Chicago and Metropolitan Minneapolis-St. Paul, 2014. MMWR Morb Mortal Wkly Rep 2015;64:597-8.

\section{Syphilis, Congenital}

From 2008 to 2012, the rate of reported congenital syphilis decreased from 10.5 to 8.4 reported cases per 100,000 live births (1). However, in 2013, the rate of reported congenital syphilis increased to 9.1 . In $2014^{*}$, the rate increased to 11.6 , a $27.5 \%$ increase relative to 2013 . Historically, increases in congenital syphilis parallel increases in primary and secondary (P\&S) syphilis among women. During 2013-2014, the reported P\&S syphilis rate among women increased $22.7 \%$.

During 2013-2014, the congenital syphilis rate increased in every region of the United States, but as in previous years, the highest rates in 2014 were reported from the South (15.5).

\footnotetext{
* Rates for 2013 and 2014 were calculated using the 2012 live birth estimates and differ from the 2013 and 2014 rates presented in the figures and table 7 (calculated using 2013 and 2014 live birth estimates, respectively).
} 
Similarly, during 2013-2014, the congenital syphilis rate increased among most race/ethnicity groups including whites, blacks, Hispanics, and Asians/Pacific Islanders, but race and ethnic disparities persisted in 2014. The rate of congenital syphilis among non-Hispanic blacks (38.2) was 10.3 times the rate among nonHispanic whites (3.7), and the rate among Hispanics (12.1) was 3.3 times the rate among non-Hispanic whites.

1. CDC. Sexually transmitted disease surveillance 2014. Atlanta, GA: US Department of Health and Human Services, CDC; 2015.

\section{Syphilis, Primary and Secondary}

In 2000 and 2001, the national rate of reported primary and secondary $(\mathrm{P} \& S)$ syphilis cases reached the lowest rate $(2.1$ cases per 100,000 population) since reporting began in 1941 . However, since 2000-2001, the P\&S syphilis rate has increased almost every year. In $2014^{*}$, the rate was 6.3 in the United States, the highest rate reported since 1994 (1). Since 2000, increases in the $P \& S$ syphilis rate have primarily been attributable to increased cases among men, specifically among gay, bisexual, and other men who have sex with men (collectively referred to as MSM). In 2014, men accounted for the majority (90.7\%) of all cases of P\&S syphilis. Among male cases with known sex of sex partner(s), 82.9\% occurred among MSM. However, during 2013-2014, the P\&S syphilis rate increased $22.7 \%$ among women (from 0.9 to 1.1 ) and $14.4 \%$ among men (from 10.2 to 11.7$)$. Increases in the overall, male, and female P\&S syphilis rates were observed in every region of the country.

\footnotetext{
* Rates for 2014 were calculated using the 2013 population estimates and differ from 2014 rates presented in the figures and table 7 (calculated using 2014 population estimates).

1. CDC. Sexually transmitted disease surveillance 2014. Atlanta, GA: US Department of Health and Human Services, CDC; 2015.
}

\section{Trichinellosis}

In 2014, a total of 11 confirmed and two probable trichinellosis cases were reported. Of these, a known or suspected source of Trichinella infection was documented for nine $(69 \%)$ and included bear (six), free-range pork (one), pork from an unspecified source (one), and hamburger (one). No likely source of infection could be identified for four cases.

An outbreak of two confirmed (one each from Texas and Utah) and two probable cases (one each from Colorado and Washington) was reported among a group of six persons who hunted and consumed meat from a black bear in Alaska. The meat was consumed "somewhat rare" after being cooked on skewers over an open fire. The Washington State Public Health Laboratory detected Trichinella larvae in a sample of leftover bear meat via microscopy. The best way to prevent Trichinella infection is to thoroughly cook all meats to the USDA-recommended temperatures (as verified with a food thermometer) before consumption (1).

1. CDC. Trichinellosis. Atlanta, GA: US Department of Health and Human Services, CDC; 2013. http://www.cdc.gov/parasites/trichinellosis/prevent.html.

\section{Tuberculosis}

Tuberculosis (TB) is one of the world's deadliest airborne diseases. It is the leading cause of death worldwide of persons living with human immunodeficiency virus (HIV), causing one fourth of all HIV-related deaths. In 2014, an estimated 9.6 million persons worldwide developed TB, and 1.5 million died from the disease (1). One third of the world's population has latent TB infection (LTBI), which can later develop into active disease (2). Many persons arrive in the United States annually from countries with high burdens of $\mathrm{TB}$, including immigrants, refugees, students, or travelers.

In the United States, new cases of TB disease have been reported annually since 1953 to the National Tuberculosis Surveillance System (NTSS) in CDC's Division of Tuberculosis Elimination (DTBE) (3). CDC receives data from 60 reporting jurisdictions (all 50 U.S. states, the District of Columbia, New York City, and eight U.S.-affiliated islands) through a standardized data collection form, the Report of Verified Case of Tuberculosis (RVCT). In 2009, the RVCT was revised and NTSS transitioned into a web-based reporting system.

The number and rate of $\mathrm{TB}$ cases have declined each year since 1993, representing steady progress toward the goal of TB elimination in the United States $(<1$ case per $1,000,000$ population). However, in 2014 , the number $(9,421)$ of new TB cases and rate of 3.0 per 100,000 population marked the smallest annual decline of incidence and TB case rate $(-2.2 \%)$ in more than a decade (4).

Among all TB cases in the United States, racial/ ethnic minorities, especially foreign-born persons, are disproportionately affected. In 2014, the proportion of persons with TB who were foreign-born increased to $66 \%(6,215$ of 9,421) of total cases (4). Non-Hispanic Asians had the largest number of TB cases and the highest incidence rate in 2014. Compared with non-Hispanic whites, the TB rate among nonHispanic Asians in 2014 was approximately 30 times higher (17.8 versus 0.6$)$. $^{*}$

TB drug resistance continues to be a major concern. During 1996-2014, the percentage of primary multidrug-resistant (MDR) TB cases, (i.e., patients with no previous history of TB

\footnotetext{
* Race/ethnicity is presented differently than in tables 5 and 6 . Persons of Hispanic ethnicity might be of any race.
} 
disease and resistant to at least isoniazid [INH] and rifampin [RIF]) has fluctuated between 1.3 and $0.9 \%$. The percentage of U.S.-born patients with primary MDR TB has remained below $1 \%$. However, of the total number of reported primary MDR $\mathrm{TB}$ cases, the proportion occurring in foreign-born persons increased from $25 \%$ in 1993 to $85 \%$ in 2014 . In addition, 15 extensively drug-resistant $\mathrm{TB}$ cases (i.e., patients with resistance to INH and RIF, plus resistance to any fluoroquinolone and at least one of three injectable second-line anti-TB drugs [i.e., amikacin, kanamycin, or capreomycin]) have been reported since 2009; of these, 11 were among foreign-born persons (4).

To achieve TB elimination, intensified efforts are needed to address the persistent disparities that exist between U.S.-born and foreign-born persons and between whites and minorities in the United States. Improved awareness, testing, and treatment of LTBI and TB disease in minorities and foreign-born populations are essential to these efforts. DTBE is developing an initiative to enhance testing, monitoring, and treatment of LTBI to prevent progression to TB disease and accelerate the decline of TB.

1. World Health Organization. Global tuberculosis report 2015, 20 th edition. http://www.who.int/tb/publications/global_report/en

2. World Health Organization. 10 facts about tuberculosis. http://www. who.int/features/factfiles/tuberculosis/en

3. CDC. Quality assurance for tuberculosis surveillance data: A guide and toolkit, Atlanta, GA: US Department of Health and Human Services, CDC; 2013.

4. CDC. Reported tuberculosis in the United States, 2014. Atlanta, GA: U.S. Department of Health and Human Services, CDC, October 2015. http://www.cdc.gov/tb/statistics/reports/2014/default.htm

\section{Typhoid Fever}

Typhoid fever is rare in the United States. Since 2009, an annual average of $<400$ cases has been reported. In 2014, a total of 349 cases were reported. Approximately $75 \%$ of U.S. cases are associated with international travel (1), and the risk for infection is highest for travelers visiting friends and relatives in countries where typhoid fever is endemic. These persons might stay for extended periods and are less likely than other travelers to seek pretravel vaccination and to observe strict safe water and food practices, possibly because of misperception of disease risk (2). The risk is also higher for travelers who visit areas where the disease is highly endemic, such as the Indian subcontinent, even for a short time (3). In 2011, CDC removed pretravel typhoid vaccination recommendations for 26 low-risk destinations; pretravel vaccination guidelines are available at http://wwwnc.cdc.gov/travel (4).

1. Lynch MF, Blanton EM, Bulens S, et al. Typhoid fever in the United States, 1999-2006. JAMA 2009;302:859-65. http://dx.doi.org/10.1001/ jama.2009.1229
2. Angell SY, Cetron MS. Health disparities among travelers visiting friends and relatives abroad. Ann Intern Med 2005;142:67-72. http://dx.doi. org/10.7326/0003-4819-142-1-200501040-00013

3. Steinberg EB, Bishop R, Haber P, et al. Typhoid fever in travelers: who should be targeted for prevention? Clin Infect Dis 2004;39:186-91. http://dx.doi.org/10.1086/421945

4. Johnson KJ, Gallagher NM, Mintz ED, Newton AE, Brunette GW, Kozarsky PE. From the CDC: new country-specific recommendations for pre-travel typhoid vaccination. J Travel Med 2011;18:430-3. http:// dx.doi.org/10.1111/j.1708-8305.2011.00563.x

\section{Varicella}

As the 2-dose varicella vaccination program continues to mature and with the discontinuation of active surveillance for varicella, national surveillance is increasingly important for monitoring impact of the program. More states are reporting varicella cases to CDC through the National Notifiable Diseases Surveillance System; reporting of varicella cases to CDC from states and the District of Columbia increased from 29 in 2006 (when the second dose of varicella vaccine was recommended for children [1]) to 40 as of 2014. Although the number of states reporting has increased, varicella incidence has declined $84.3 \%$ from an average of 25.4 per 100,000 population during 2005-2006 to 4.0 in 2014.

To monitor impact of the varicella vaccination program, data from key variables such as age, vaccination status, disease severity (e.g., number of lesions), outcome of the case (e.g., hospitalized), and whether the case is associated with an outbreak, are used. In 2014, a total of 10,089 (99\%) of 10,172 cases reported to CDC from 40 states had data on at least one of the key variables important for monitoring the varicella vaccination program; completeness was $95 \%(9,622)$ for age, $60 \%(6,077)$ for vaccination status, $43 \%(4,344)$ for disease severity, $8 \%$ (802) for whether the case resulted in hospitalization, and $84 \%(8,493)$ for whether the case was associated with an outbreak. Of the cases with data reported for each of the key variables, 52\% $(4,975)$ was for persons aged $1-9$ years, $22 \%(2,165)$ for those aged $10-19$ years, and $18 \%(1,726)$ for those aged $\geq 20$ years; $55 \%(3,330)$ was for persons who had received at least 1 dose of varicella vaccine. Of those with information on number of doses, $56 \%(1,330$ of 2,358$)$ had received 2 doses, $48 \%(2,081)$ had mild disease presentation ( $<50$ lesions), 3\% (25) resulted in hospitalization, and $11 \%$ (919) were associated with outbreaks. Laboratory testing for varicella was performed for $25 \%(1,159$ of $4,696)$ of reported cases, of which $79 \%(912$ of 1,159$)$ were laboratory confirmed.

Much of the varicella data should be interpreted with caution because of the large proportion of missing data. States continue improving varicella surveillance practices (2) and are working to increase completeness of reporting for the variables important 
for monitoring the varicella vaccination program. As varicella incidence continues to decline, national surveillance data will provide the information needed to monitor progress and changing varicella epidemiology.

1. Marin M, Güris D, Chaves SS, Schmid S, Seward JF. Prevention of varicella: recommendations of the Advisory Committee on Immunization Practices (ACIP). MMWR Recomm Rep 2007;56(No. RR-4).

2. Lopez AS, Lichtenstein M, Schmid SD, Bialek S. Assessment of varicella surveillance and outbreak control practices-United States, 2012. MMWR Morb Mortal Wkly Rep 2014;63:785-8.

\section{Vibriosis}

The incidence of vibriosis, defined as infection caused by a species from the family Vibrionaceae other than toxigenic Vibrio cholerae $\mathrm{O} 1$ or O139, has increased during 2007-2014 (1). In 2012, an outbreak of $V$. parahaemolyticus infections was associated with consumption of shellfish harvested from Oyster Bay Harbor, New York (2). Now endemic on the Atlantic Coast, this same strain continued to cause illness in 2013 and 2014 (3).

1. Newton A, Kendall M, Vugia DJ, Henao OL, Mahon BE. Increasing rates of vibriosis in the United States, 1996-2010: review of surveillance data from 2 systems. Clin Infect Dis 2012;54(Suppl 5):S391-5. http:// dx.doi.org/10.1093/cid/cis243

2. Martinez-Urtaza J, Baker-Austin C, Jones JL, Newton AE, Gonzalez-Aviles GD, DePaola A. Spread of Pacific Northwest Vibrio parahaemolyticus strain. N Engl J Med 2013;369:1573-4. http://dx.doi.org/10.1056/ NEJMc1305535

3. Newton AE, Garrett N, Stroika SG, Halpin JL, Turnsek M, Mody RK. Increase in Vibrio parahaemolyticus infections associated with consumption of Atlantic Coast shellfish-2013. MMWR Morb Mortal Wkly Rep 2014;63:335-6.

\section{Viral Hemorrhagic Fever}

Viral Hemorrhagic Fever (VHF) is a group of acute febrile illnesses that are caused by approximately 30 viruses (1). Many are of substantial public health concern, particularly in Africa and South America, with the possibility of importation to the United States. Nationally notifiable VHFs are those with documented person to person transmission: Crimean-Congo hemorrhagic fever, Ebola virus disease (EVD), Lassa fever, Lujo, Marburg, and several New World Arenaviruses (Junin, Machupo, Guanarito, Sabia).

The 2014-16 West African EVD epidemic is the largest in history, with approximately 28,000 cases and 11,000 deaths (2). Such large numbers of cases presented new challenges in effectively diagnosing patients with EVD, caring for affected patients, and containing the epidemic. In 2014, a total of 10 persons with EVD received medical care in the United States. Six were medically evacuated to the United States after having
EVD diagnosed in West Africa (3-6); four had the disease diagnosed in the United States. The four EVD cases diagnosed in the United States consisted of traveler from Liberia with two subsequent nosocomial infections (7-11) and a medical aid worker who returned from Guinea (12). These were the first EVD cases to receive care in the United States. Previously, a patient with Marburg virus disease was cared for in Colorado in 2007 (13).

In response to the concern about importation of EVD to the United States, national and state level surveillance systems were enhanced in 2014 (14-18). In October 2014, all airline passengers who had traveled to Liberia, Sierra Leone, and Guinea within the previous 21 days were diverted to five airports for admittance to the United States using enhanced screening methods (19). At risk travelers and health care workers were required to complete a 21-day active monitoring period $(17,18)$. In addition, CDC responded to inquiries from state and local health officials and health care providers and facilitated testing of persons under investigation $(20,21)$.

One imported case of Lassa fever was reported in April 2014. This is only the seventh known imported case to the United States (22). Lassa fever is endemic in West Africa, with an estimated 100,000 to 300,000 cases and 5,000 deaths annually.

1. Rollin PE, Nichol ST, Zaki S, Ksiazek TG. Arenaviruses and filoviruses. In: Murray PR, Baron EJ, Landry ML, Jorgensen JH, Pfaller MA, eds. Manual of clinical microbiology, 11th edition. Washington, DC: ASM Press; 2015:1669-86.

2. World Health Organization. Ebola Situation Report, November 2015. http://apps.who.int/ebola/current-situation/ ebola-situation-report-4-november-2015

3. Lyon GM, Mehta AK, Varkey JB, et al. Clinical care of two patients with Ebola virus disease in the United States. N Engl J Med 2014;371:2402-9. http://dx.doi.org/10.1056/NEJMoa1409838

4. Stephens DS, Ribner BS, Gartland BD, et al. Ebola virus disease: Experience and decision making for the first patients outside of Africa. PLoS Med 2015;12:e1001857. http://dx.doi.org/10.1371/journal. pmed.1001857

5. Sueblinvong V, Johnson DW, Weinstein GL, et al. Critical care for multiple organ failure secondary to Ebola virus disease in the United States. Crit Care Med 2015;43:2066-75. http://dx.doi. org/10.1097/CCM.0000000000001197

6. Goodnough A. (2014, October 10). After years of empty beds, a medical team in Omaha puts its skills into practice. The New York Times, p. A14.

7. Chevalier MS, Chung W, Smith J, et al. Ebola virus disease cluster in the United States—Dallas County, Texas, 2014. MMWR Morb Mortal Wkly Rep 2014;63:1087-8.

8. McCarty CL, Basler C, Karwowski M, et al. Response to importation of a case of Ebola virus disease-Ohio, October 2014. MMWR Morb Mortal Wkly Rep 2014;63:1089-91.

9. Regan JJ, Jungerman R, Montiel SH, et al. Public health response to commercial airline travel of a person with Ebola virus infection United States, 2014. MMWR Morb Mortal Wkly Rep 2015;64:63-6.

10. Chung WM, Smith JC, Weil LM, et al. Active tracing and monitoring of contacts associated with the first cluster of Ebola in the United States. Ann Intern Med 2015;163:164-73. http://dx.doi.org/10.7326/ M15-0968. 
11. Liddell AM, Davey RT Jr, Mehta AK, et al. Characteristics and clinical management of a cluster of 3 patients with Ebola virus disease, including the first domestically acquired cases in the United States. Ann Intern Med 2015;163:81-90. http://dx.doi.org/10.7326/M15-0530

12. Yacisin K, Balter S, Fine A, et al. Ebola virus disease in a humanitarian aid worker-New York City, October 2014. MMWR Morb Mortal Wkly Rep 2015;64:321-3.

13. CDC. Imported case of Marburg hemorrhagic fever-Colorado, 2008. MMWR Morb Mortal Wkly Rep 2009;58:1377-81.

14. Koonin LM, Jamieson DJ, Jernigan JA, et al. Systems for rapidly detecting and treating persons with ebola virus disease-United States. MMWR Morb Mortal Wkly Rep 2015;64:222-5.

15. Sunshine G, Pepin D, Cetron M, Penn M. State and territorial Ebola screening, monitoring, and movement policy statements_-United States, August 31, 2015. MMWR Morb Mortal Wkly Rep 2015;64:1145-6. http://dx.doi.org/10.15585/mmwr.mm6440a4

16. Benowitz I, Ackelsberg J, Balter SE, et al. Surveillance and preparedness for Ebola virus disease - New York City, 2014. MMWR Morb Mortal Wkly Rep 2014;63:934-6.

17. Parham M, Edison L, Soetebier K, et al. Ebola active monitoring system for travelers returning from West Africa-Georgia, 2014-2015. MMWR Morb Mortal Wkly Rep 2015;64:347-50.
18. Stehling-Ariza T, Fisher E, Vagi S, et al. Monitoring of persons with risk for exposure to Ebola virus disease-United States, November 3, 2014-March 8, 2015. MMWR Morb Mortal Wkly Rep 2015;64:685-9.

19. Brown CM, Aranas AE, Benenson GA, et al. Airport exit and entry screening for Ebola-August-November 10, 2014. MMWR Morb Mortal Wkly Rep 2014;63:1163-7.

20. Karwowski M, Meites E, Fullerton K, et al. Clinical inquiries regarding Ebola virus disease received by CDC_-United States, July 9November 15, 2014. MMWR Morb Mortal Wkly 2015;63:1175-9.

21. Goodman AB, Meites E, Anstey EH, et al. Clinical inquiries received by CDC regarding suspected Ebola Virus Disease in childrenUnited States, July 9, 2014-January 4, 2015. MMWR Morb Mortal Wkly Rep 2015;64:1006-10. http://dx.doi.org/10.15585/mmwr. mm6436a3

22. Amorosa V, MacNeil A, McConnell R, et al. Imported Lassa fever, Pennsylvania, USA, 2010. Emerg Infect Dis 2010;16:1598-600. http:// dx.doi.org/10.3201/eid1610.100774 



\section{PART 1 \\ Summary of Notifiable Diseases \\ in the United States, 2014}

\begin{tabular}{|ll|}
\hline & Abbreviations and Symbols Used in Tables \\
$\mathbf{N}$ & Data not available. \\
& Not reportable (i.e., report of disease is not required in that \\
jurisdiction). & No reported cases. \\
Notes: $\quad$ & Rates $<0.01$ after rounding are listed as 0. \\
& Data in the MMWR Summary of Notifiable Diseases - United States, \\
& 2014 might differ from data in other CDC surveillance reports \\
because of differences in the timing of reports, the source of the \\
data, the use of different case definitions, and print criteria.
\end{tabular}




\begin{tabular}{|c|c|c|c|c|c|c|c|c|c|c|c|c|c|c|}
\hline Disease & Jan. & Feb. & Mar. & Apr. & May & June & July & Aug. & Sept. & Oct. & Nov. & Dec. & $\begin{array}{c}\text { Not } \\
\text { stated }\end{array}$ & Total \\
\hline \multicolumn{15}{|l|}{ Arboviral diseases ${ }^{\S}$} \\
\hline \multicolumn{15}{|l|}{ California serogroup viruses } \\
\hline neuroinvasive & - & - & 1 & - & 2 & 1 & 19 & 29 & 28 & 5 & - & - & - & 85 \\
\hline nonneuroinvasive & - & - & - & - & - & 2 & 4 & 4 & 1 & - & - & - & - & 11 \\
\hline \multicolumn{15}{|l|}{ Eastern equine encephalitis virus } \\
\hline neuroinvasive & - & - & - & - & - & - & 1 & 3 & 4 & - & - & - & - & 8 \\
\hline \multicolumn{15}{|l|}{ Powassan virus } \\
\hline neuroinvasive & - & - & - & - & 2 & - & 2 & 1 & 2 & - & - & - & - & 7 \\
\hline nonneuroinvasive & - & - & - & - & 1 & - & - & - & - & - & - & - & - & 1 \\
\hline \multicolumn{15}{|l|}{ St. Louis encephalitis virus } \\
\hline neuroinvasive & 1 & - & - & - & - & - & 2 & 3 & - & - & - & - & - & 6 \\
\hline nonneuroinvasive & - & - & - & 1 & - & - & - & 1 & - & 2 & - & - & - & 4 \\
\hline \multicolumn{15}{|l|}{ West Nile virus } \\
\hline neuroinvasive & - & 1 & 1 & - & 2 & 28 & 182 & 547 & 480 & 88 & 15 & 3 & - & 1,347 \\
\hline nonneuroinvasive & - & 1 & - & - & 4 & 24 & 129 & 390 & 257 & 46 & 4 & 3 & - & 858 \\
\hline Babesiosis, total & 8 & 8 & 15 & 11 & 45 & 221 & 526 & 535 & 158 & 72 & 72 & 89 & - & 1,760 \\
\hline confirmed & 6 & 6 & 7 & 4 & 34 & 184 & 476 & 462 & 120 & 51 & 52 & 70 & - & 1,472 \\
\hline probable & 2 & 2 & 8 & 7 & 11 & 37 & 50 & 73 & 38 & 21 & 20 & 19 & - & 288 \\
\hline Botulism, total & 11 & 10 & 11 & 16 & 8 & 19 & 10 & 19 & 9 & 20 & 12 & 16 & - & 161 \\
\hline foodborne & - & 1 & - & - & - & 1 & 2 & 6 & 1 & - & - & 4 & - & 15 \\
\hline infant & 9 & 9 & 8 & 13 & 6 & 15 & 7 & 11 & 8 & 19 & 11 & 11 & - & 127 \\
\hline other (wound and unspecified) & 2 & - & 3 & 3 & 2 & 3 & 1 & 2 & - & 1 & 1 & 1 & - & 19 \\
\hline Brucellosis & 2 & 5 & 4 & 8 & 15 & 7 & 5 & 16 & 11 & 4 & 5 & 10 & - & 92 \\
\hline Chancroid" & - & 1 & - & - & 1 & 1 & - & 1 & 2 & - & - & - & - & 6 \\
\hline Chlamydia trachomatis infection" & 97,157 & 109,226 & 142,149 & 110,169 & 132,858 & 111,251 & 107,315 & 144,706 & 114,508 & 114,227 & 132,164 & 126,059 & - & $1,441,789$ \\
\hline Cholera & - & 1 & - & 1 & - & - & - & 2 & - & - & 1 & - & - & 5 \\
\hline Coccidioidomycosis ${ }^{* *}$ & 761 & 847 & 890 & 676 & 956 & 671 & 483 & 619 & 542 & 483 & 600 & 704 & - & 8,232 \\
\hline Cryptosporidiosis, total & 334 & 417 & 502 & 434 & 529 & 534 & 793 & 1,637 & 1,250 & 953 & 666 & 633 & - & 8,682 \\
\hline confirmed & 224 & 253 & 292 & 264 & 311 & 314 & 490 & 1,138 & 838 & 612 & 406 & 423 & - & 5,565 \\
\hline probable & 110 & 164 & 210 & 170 & 218 & 220 & 303 & 499 & 412 & 341 & 260 & 210 & - & 3,117 \\
\hline Cyclosporiasis & - & 5 & 2 & 3 & 13 & 36 & 135 & 152 & 22 & 15 & 7 & 8 & - & 398 \\
\hline Dengue fever $\S$ & 46 & 27 & 23 & 23 & 40 & 54 & 76 & 85 & 56 & 66 & 137 & 47 & - & 680 \\
\hline Diphtheria & - & - & - & 1 & - & - & - & - & - & - & - & - & - & 1 \\
\hline \multicolumn{15}{|l|}{ Ehrlichiosis/Anaplasmosis } \\
\hline Anaplasma phagocytophilum & 13 & 18 & 20 & 53 & 351 & 662 & 611 & 339 & 138 & 163 & 302 & 130 & - & 2,800 \\
\hline Ehrlichia chaffeensis & 5 & 8 & 6 & 21 & 149 & 313 & 310 & 311 & 131 & 65 & 101 & 55 & - & 1,475 \\
\hline Ehrlichia ewingii & - & - & 1 & - & 1 & 1 & 5 & 8 & - & 1 & - & - & - & 17 \\
\hline undetermined & 3 & 1 & 4 & 5 & 21 & 47 & 38 & 34 & 20 & 8 & 9 & 6 & - & 196 \\
\hline Giardiasis & 835 & 954 & 1,204 & 989 & 1,221 & 1,012 & 1,197 & 1,973 & 1,464 & 1,238 & 1,296 & 1,171 & - & 14,554 \\
\hline Gonorrhea? & 24,079 & 25,407 & 31,899 & 25,395 & 31,273 & 27,111 & 27,073 & 35,376 & 28,522 & 27,492 & 33,167 & 33,268 & - & 350,062 \\
\hline \multicolumn{15}{|l|}{ Haemophilus influenzae, invasive disease } \\
\hline $\begin{array}{l}\text { all ages, serotypes } \\
\text { age }<5 \text { yrs }\end{array}$ & 328 & 285 & 356 & 280 & 323 & 255 & 253 & 271 & 204 & 235 & 299 & 452 & - & 3,541 \\
\hline serotype b & 1 & 2 & 6 & 2 & 4 & 1 & 1 & 4 & 1 & 4 & 5 & 9 & - & 40 \\
\hline nontypeable & 16 & 18 & 20 & 8 & 8 & 7 & 9 & 3 & 5 & 6 & 9 & 19 & - & 128 \\
\hline non-b serotype & 6 & 2 & 7 & 1 & 2 & 5 & 1 & 3 & 3 & 3 & 4 & 1 & - & 38 \\
\hline unknown serotype & 27 & 23 & 34 & 28 & 28 & 21 & 11 & 16 & 18 & 19 & 19 & 22 & - & 266 \\
\hline Hansen's disease & 1 & 10 & 7 & 7 & 5 & 8 & 9 & 9 & 6 & 5 & 5 & 16 & - & 88 \\
\hline Hantavirus pulmonary syndrome & 2 & 1 & 2 & 3 & 5 & 4 & 6 & 1 & 1 & 2 & 3 & 2 & - & 32 \\
\hline Hemolytic uremic syndrome postdiarrheal & 4 & 12 & 11 & 12 & 18 & 27 & 31 & 41 & 32 & 21 & 20 & 21 & - & 250 \\
\hline Hepatitis, virus & & & & & & & & & & & & & & \\
\hline A acute & 62 & 96 & 107 & 83 & 142 & 86 & 87 & 151 & 117 & 86 & 99 & 123 & - & 1,239 \\
\hline B acute & 205 & 206 & 282 & 222 & 280 & 199 & 188 & 264 & 217 & 189 & 258 & 281 & - & 2,791 \\
\hline B chronic & 937 & 941 & 1,517 & 1,068 & 1,330 & 1,069 & 958 & 1,135 & 835 & 764 & 988 & 858 & - & 12,400 \\
\hline B infection perinatal & 3 & 5 & 4 & 6 & 4 & 4 & 3 & 2 & 4 & 1 & 5 & 6 & - & 47 \\
\hline Cacute & 121 & 171 & 244 & 171 & 238 & 143 & 166 & 214 & 158 & 117 & 226 & 235 & - & 2,204 \\
\hline C past or present & 9,256 & 11,158 & 15,679 & 12,670 & 15,395 & 13,707 & 12,401 & 15,532 & 12,269 & 13,030 & 15,758 & 16,008 & - & 162,863 \\
\hline $\begin{array}{l}\text { Human immunodeficiency virus } \\
\text { (HIV) diagnoses }{ }^{t+}\end{array}$ & 3,602 & 3,209 & 3,528 & 3,552 & 3,506 & 3,470 & 3,512 & 3,247 & 3,100 & 2,812 & 1,664 & 401 & 3 & 35,606 \\
\hline $\begin{array}{l}\text { Influenza-associated pediatric mortality } \$ \S \\
\text { Invasive pneumococcal disease }\end{array}$ & 31 & 24 & 21 & 9 & 6 & 3 & 5 & 13 & 2 & 2 & 4 & 21 & - & 141 \\
\hline all ages & 1,722 & 1,575 & 1,955 & 1,481 & 1,585 & 832 & 626 & 588 & 706 & 802 & 1,200 & 2,284 & - & 15,356 \\
\hline age $<5$ yrs & 77 & 89 & 140 & 111 & 100 & 61 & 44 & 46 & 58 & 85 & 104 & 150 & - & 1,065 \\
\hline Legionellosis & 205 & 185 & 277 & 261 & 390 & 495 & 607 & 717 & 561 & 470 & 484 & 514 & - & 5,166 \\
\hline Leptospirosis & 2 & 2 & 3 & 2 & 3 & 1 & 3 & 3 & 5 & 3 & 7 & 4 & - & 38 \\
\hline Listeriosis & 39 & 21 & 42 & 45 & 56 & 63 & 81 & 104 & 89 & 69 & 80 & 80 & - & 769 \\
\hline Lyme disease, total & 653 & 608 & 856 & 979 & 2,201 & 5,210 & 7,700 & 6,502 & 2,868 & 2,071 & 2,124 & 1,689 & - & 33,461 \\
\hline confirmed & 438 & 434 & 604 & 682 & 1,523 & 4,100 & 6,227 & 5,088 & 2,124 & 1,454 & 1,482 & 1,203 & - & 25,359 \\
\hline probable & 215 & 174 & 252 & 297 & 678 & 1,110 & 1,473 & 1,414 & 744 & 617 & 642 & 486 & - & 8,102 \\
\hline
\end{tabular}

See table footnotes on next page. 
Morbidity and Mortality Weekly Report

TABLE 1. (Continued) Number of reported cases of notifiable diseases, ${ }^{*}$ by month, ${ }^{\dagger}$ excluding U.S. territories — United States, 2014

\begin{tabular}{|c|c|c|c|c|c|c|c|c|c|c|c|c|c|c|}
\hline Disease & Jan. & Feb. & Mar. & Apr. & May & June & July & Aug. & Sept. & Oct. & Nov. & Dec. & $\begin{array}{c}\text { Not } \\
\text { stated }\end{array}$ & Total \\
\hline Malaria & 110 & 86 & 91 & 84 & 170 & 177 & 191 & 246 & 154 & 112 & 121 & 111 & - & 1,653 \\
\hline Measles, total & 15 & 46 & 49 & 27 & 196 & 210 & 31 & 15 & 4 & 10 & 7 & 57 & - & 667 \\
\hline indigenous & 6 & 32 & 44 & 16 & 189 & 207 & 29 & 15 & 1 & 7 & 4 & 54 & - & 604 \\
\hline imported & 9 & 14 & 5 & 11 & 7 & 3 & 2 & - & 3 & 3 & 3 & 3 & - & 63 \\
\hline \multicolumn{15}{|l|}{ Meningococcal disease } \\
\hline all serogroups & 53 & 44 & 55 & 36 & 39 & 30 & 14 & 28 & 27 & 32 & 29 & 46 & - & 433 \\
\hline serogroups ACWY & 18 & 7 & 19 & 12 & 8 & 9 & 7 & 7 & 6 & 6 & 9 & 15 & - & 123 \\
\hline serogroup B & 9 & 6 & 13 & 7 & 11 & 1 & - & 4 & 7 & 9 & 6 & 16 & - & 89 \\
\hline other serogroups & 3 & 4 & 2 & 3 & - & 2 & - & 3 & 1 & 2 & 3 & 2 & - & 25 \\
\hline unknown serogroup & 23 & 27 & 21 & 14 & 20 & 18 & 7 & 14 & 13 & 15 & 11 & 13 & - & 196 \\
\hline Mumps & 26 & 52 & 168 & 335 & 242 & 99 & 48 & 48 & 22 & 29 & 47 & 107 & - & 1,223 \\
\hline Novel influenza A virus infection & - & - & - & - & - & - & - & 2 & - & 1 & - & - & - & 3 \\
\hline Pertussis & 1,984 & 1,925 & 2,375 & 2,236 & 3,755 & 3,238 & 3,073 & 3,358 & 2,142 & 2,038 & 3,199 & 3,648 & - & 32,971 \\
\hline Plague & - & - & - & 1 & - & - & 5 & 1 & 1 & - & 1 & 1 & - & 10 \\
\hline Psittacosis & - & - & 1 & - & - & - & - & - & 1 & 2 & 3 & 1 & - & 8 \\
\hline Q fever, total & 11 & 9 & 19 & 18 & 19 & 13 & 11 & 24 & 12 & 10 & 7 & 15 & - & 168 \\
\hline acute & 9 & 8 & 13 & 14 & 15 & 12 & 10 & 16 & 11 & 5 & 5 & 14 & - & 132 \\
\hline chronic & 2 & 1 & 6 & 4 & 4 & 1 & 1 & 8 & 1 & 5 & 2 & 1 & - & 36 \\
\hline \multicolumn{15}{|l|}{ Rabies } \\
\hline animal & 267 & 292 & 394 & 573 & 515 & 449 & 511 & 756 & 675 & 567 & 292 & 277 & 420 & 5,988 \\
\hline human & - & - & - & - & - & - & - & - & 1 & - & - & - & - & 1 \\
\hline Rubella & - & - & 2 & - & 1 & 1 & - & - & - & - & 1 & 1 & - & 6 \\
\hline Rubella, congenital syndrome & - & - & - & 1 & - & - & - & - & - & - & - & - & - & 1 \\
\hline Salmonellosis & 1,981 & 2,122 & 2,691 & 2,652 & 4,264 & 4,538 & 5,538 & 7,954 & 5,837 & 5,085 & 4,936 & 3,857 & - & 51,455 \\
\hline Shiga toxin-producing E. coli (STEC) & 195 & 193 & 354 & 369 & 541 & 624 & 839 & 948 & 604 & 455 & 543 & 514 & - & 6,179 \\
\hline Shigellosis & 939 & 825 & 1,179 & 1,163 & 1,980 & 1,838 & 2,032 & 2,132 & 1,875 & 2,077 & 2,319 & 2,386 & - & 20,745 \\
\hline Spotted fever rickettsiosis, total & 39 & 30 & 77 & 105 & 426 & 745 & 612 & 633 & 339 & 235 & 301 & 215 & - & 3,757 \\
\hline confirmed & 1 & 1 & 2 & 1 & 12 & 23 & 26 & 17 & 8 & 8 & 12 & 4 & - & 115 \\
\hline probable & 38 & 28 & 75 & 104 & 414 & 722 & 583 & 612 & 331 & 227 & 289 & 211 & - & 3,634 \\
\hline Streptococcal toxic shock syndrome & 29 & 26 & 36 & 26 & 23 & 24 & 18 & 13 & 10 & 6 & 17 & 31 & - & 259 \\
\hline Syphilis, total, all stages $\mathbb{\eta}_{1} * * * *$ & 4,143 & 4,464 & 6,056 & 4,795 & 6,090 & 5,153 & 4,935 & 6,269 & 5,086 & 5,223 & 5,604 & 5,632 & - & 63,450 \\
\hline primary and secondary" & 1,349 & 1,377 & 1,805 & 1,449 & 1,902 & 1,635 & 1,558 & 2,040 & 1,622 & 1,640 & 1,773 & 1,849 & - & 19,999 \\
\hline congenital" & 39 & 36 & 37 & 26 & 36 & 36 & 32 & 48 & 48 & 43 & 38 & 39 & - & 458 \\
\hline Tetanus & 2 & 2 & 1 & 2 & 3 & 3 & 4 & 3 & - & 2 & - & 3 & - & 25 \\
\hline $\begin{array}{l}\text { Toxic shock syndrome } \\
\text { (other than streptococcal) }\end{array}$ & 7 & 2 & 6 & 3 & 6 & 1 & 10 & 3 & 6 & 1 & 8 & 6 & - & 59 \\
\hline Trichinellosis & - & 1 & - & - & 3 & 1 & 3 & 1 & - & - & 2 & 2 & - & 13 \\
\hline Tuberculosis $^{\dagger \dagger t}$ & 503 & 535 & 726 & 879 & 786 & 796 & 775 & 879 & 779 & 777 & 714 & 1,272 & - & 9,421 \\
\hline Tularemia & 1 & - & 1 & 6 & 19 & 31 & 41 & 25 & 16 & 19 & 10 & 11 & - & 180 \\
\hline Typhoid fever & 23 & 28 & 36 & 25 & 36 & 31 & 34 & 46 & 40 & 19 & 9 & 22 & - & 349 \\
\hline $\begin{array}{l}\text { Vancomycin-intermediate } \\
\text { Staphylococcus aureus (VISA) }\end{array}$ & 13 & 18 & 20 & 20 & 17 & 16 & 16 & 20 & 28 & 12 & 17 & 15 & - & 212 \\
\hline \multicolumn{15}{|l|}{ Varicella (Chickenpox) } \\
\hline morbidity & 603 & 676 & 972 & 869 & 1,270 & 843 & 580 & 726 & 913 & 877 & 1,008 & 835 & - & 10,172 \\
\hline mortality $\S \S$ & - & - & - & - & - & 1 & - & 1 & - & 1 & 1 & - & - & 4 \\
\hline Vibriosis & 20 & 19 & 36 & 30 & 68 & 106 & 162 & 343 & 197 & 130 & 77 & 73 & - & 1,261 \\
\hline Viral hemorrhagic fevers & - & - & - & 1 & - & - & - & - & - & 4 & - & - & - & 5 \\
\hline Yellow fever $§$ & - & - & - & - & - & - & - & - & - & - & - & - & - & - \\
\hline
\end{tabular}

* No cases of anthrax; dengue hemorrhagic fever (and dengue shock syndrome), eastern equine encephalitis, nonneuroinvasive disease; poliomyelitis, paralytic; poliovirus infection, nonparalytic; severe acute respiratory syndrome-associated Coronavirus disease (SARS-CoV); smallpox; vancomycin-resistant Staphylococcus aureus (VRSA); western equine encephalitis, neuroinvasive and nonneuroinvasive disease; or yellow fever were reported in the United States during 2014.

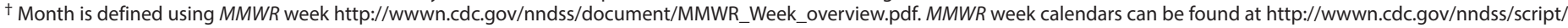
downloads.aspx.

$\S$ Totals reported to the Division of Vector-Borne Diseases, National Center for Emerging and Zoonotic Infectious Diseases (ArboNET Surveillance), as of July 1, 2015.

II Totals reported to the Division of STD Prevention, National Center for HIV/AIDS, Viral Hepatitis, STD, and TB Prevention (NCHHSTP), as of June 10, 2015.

** Reportable in $<25$ states.

${ }^{+\dagger}$ Total number of HIV diagnoses reported to the Division of HIV/AIDS Prevention, NCHHSTP through December 31, 2014

$\S \S$ Totals reported to the Influenza Division, National Center for Immunization and Respiratory Diseases (NCIRD), as of June 30, 2015.

१ी Totals reported to the National Center for Emerging and Zoonotic Infectious Diseases, Division of High Consequence Pathogens and Pathology, as of October 30, 2015.

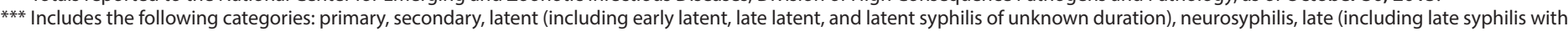
clinical manifestations other than neurosyphilis), and congenital syphilis. Totals reported to the Division of STD Prevention, NCHHSTP, as of June 10, 2015.

$\mathrm{tt}^{+\dagger}$ Totals reported to the Division of Tuberculosis Elimination, NCHHSTP, as of July 15, 2015.

$\S \S \S$ Totals reported to the Division of Viral Diseases, NCIRD, as of June 30, 2015. 
TABLE 2a. Number of reported cases of notifiable diseases, ${ }^{*}$ by region and reporting area — United States and U.S. territories, 2014

\begin{tabular}{|c|c|c|c|c|c|c|c|c|c|c|}
\hline \multirow[b]{3}{*}{ Area } & \multirow{3}{*}{$\begin{array}{c}\text { Total } \\
\text { resident } \\
\text { population } \\
\quad \text { (in } \\
\text { thousands) }\end{array}$} & \multicolumn{9}{|c|}{ Arboviruses $^{\dagger}$} \\
\hline & & \multicolumn{2}{|c|}{$\begin{array}{l}\text { California } \\
\text { serogroup }\end{array}$} & \multirow{2}{*}{$\begin{array}{c}\begin{array}{c}\text { Eastern equine } \\
\text { encephalitis }\end{array} \\
\begin{array}{c}\text { Neuro- } \\
\text { invasive }\end{array}\end{array}$} & \multicolumn{2}{|c|}{ Powassan } & \multicolumn{2}{|c|}{$\begin{array}{c}\text { St. Louis } \\
\text { encephalitis }\end{array}$} & \multicolumn{2}{|c|}{ West Nile } \\
\hline & & $\begin{array}{c}\text { Neuro- } \\
\text { invasive }\end{array}$ & $\begin{array}{l}\text { Nonneuro- } \\
\text { invasive }\end{array}$ & & $\begin{array}{c}\text { Neuro- } \\
\text { invasive }\end{array}$ & $\begin{array}{l}\text { Nonneuro- } \\
\text { invasive }\end{array}$ & $\begin{array}{c}\text { Neuro- } \\
\text { invasive }\end{array}$ & $\begin{array}{l}\text { Nonneuro- } \\
\text { invasive }\end{array}$ & $\begin{array}{c}\text { Neuro- } \\
\text { invasive }\end{array}$ & $\begin{array}{c}\text { Nonneuro- } \\
\text { invasive }\end{array}$ \\
\hline United States & 318,856 & 85 & 11 & 8 & 7 & 1 & 6 & 4 & 1,347 & 858 \\
\hline New England & 14,681 & 2 & - & 4 & 4 & - & - & - & 8 & 4 \\
\hline Connecticut & 3,597 & - & - & - & - & - & - & - & 3 & 3 \\
\hline Maine & 1,330 & - & - & 1 & - & - & - & - & - & - \\
\hline Massachusetts & 6,745 & 2 & - & - & 4 & - & - & - & 5 & 1 \\
\hline New Hampshire & 1,327 & - & - & 3 & - & - & - & - & - & - \\
\hline Rhode Island & 1,055 & - & - & - & - & - & - & - & - & - \\
\hline Vermont & 627 & - & - & - & - & & - & - & - & - \\
\hline Mid. Atlantic & 41,471 & - & - & 2 & 1 & 1 & - & - & 36 & 11 \\
\hline New Jersey & 8,938 & - & - & - & 1 & - & - & - & 6 & 2 \\
\hline New York (upstate) & 11,255 & - & - & 2 & - & 1 & - & - & 7 & 4 \\
\hline New York City & 8,491 & - & - & - & - & - & - & - & 12 & 3 \\
\hline Pennsylvania & 12,787 & - & - & - & - & - & - & - & 11 & 2 \\
\hline E.N. Central & 46,740 & 37 & 6 & 1 & 2 & - & - & - & 59 & 13 \\
\hline Illinois & 12,881 & - & 1 & - & - & - & - & - & 36 & 8 \\
\hline Indiana & 6,597 & 2 & - & - & - & - & - & - & 9 & 1 \\
\hline Michigan & 9,910 & - & - & 1 & - & - & - & - & 1 & - \\
\hline Ohio & 11,594 & 30 & 1 & - & - & - & - & - & 10 & 1 \\
\hline Wisconsin & 5,758 & 5 & 4 & - & 2 & - & - & - & 3 & 3 \\
\hline W.N. Central & 21,006 & 6 & 2 & - & - & - & - & - & 104 & 221 \\
\hline lowa & 3,107 & - & - & - & - & - & - & - & 5 & 10 \\
\hline Kansas & 2,904 & - & - & - & - & - & - & - & 18 & 36 \\
\hline Minnesota & 5,457 & 6 & 2 & - & - & - & - & - & 6 & 15 \\
\hline Missouri & 6,064 & - & - & - & - & - & - & - & 10 & 3 \\
\hline Nebraska & 1,882 & - & - & - & - & - & - & - & 41 & 101 \\
\hline North Dakota & 739 & - & - & - & - & - & - & - & 12 & 11 \\
\hline South Dakota & 853 & - & - & - & - & - & - & - & 12 & 45 \\
\hline S. Atlantic & 62,513 & 28 & 2 & - & - & - & 2 & - & 38 & 11 \\
\hline Delaware & 936 & - & - & - & - & - & - & - & - & - \\
\hline District of Columbia & 659 & - & - & - & - & - & - & - & 1 & 2 \\
\hline Florida & 19,893 & 1 & - & - & - & - & 2 & - & 12 & 5 \\
\hline Georgia & 10,097 & 1 & 1 & - & - & - & - & - & 11 & 2 \\
\hline Maryland & 5,976 & - & - & - & - & - & - & - & 6 & - \\
\hline North Carolina & 9,944 & 23 & - & - & - & - & - & - & - & - \\
\hline South Carolina & 4,832 & - & - & - & - & - & - & - & 3 & - \\
\hline Virginia & 8,326 & 2 & - & - & - & - & - & - & 5 & 2 \\
\hline West Virginia & 1,850 & 1 & 1 & - & - & - & - & - & - & - \\
\hline E.S. Central & 18,805 & 12 & 1 & 1 & - & - & 3 & - & 38 & 24 \\
\hline Alabama & 4,849 & - & - & 1 & - & - & 1 & - & - & 2 \\
\hline Kentucky & 4,413 & - & - & - & - & - & - & - & - & 1 \\
\hline Mississippi & 2,994 & - & 1 & - & - & - & 2 & - & 26 & 17 \\
\hline Tennessee & 6,549 & 12 & - & - & - & - & - & - & 12 & 4 \\
\hline W.S. Central & 38,451 & - & - & - & - & - & 1 & 3 & 332 & 201 \\
\hline Arkansas & 2,966 & - & - & - & - & - & - & - & 9 & 2 \\
\hline Louisiana & 4,650 & - & - & - & - & - & - & - & 61 & 64 \\
\hline Oklahoma & 3,878 & - & - & - & - & - & - & - & 9 & 9 \\
\hline Texas & 26,957 & - & - & - & - & - & 1 & 3 & 253 & 126 \\
\hline Mountain & 23,197 & - & - & - & - & - & - & 1 & 157 & 126 \\
\hline Arizona & 6,731 & - & - & - & - & - & - & 1 & 80 & 27 \\
\hline Colorado & 5,356 & - & - & - & - & - & - & - & 46 & 72 \\
\hline Idaho & 1,634 & - & - & - & - & - & - & - & 6 & 13 \\
\hline Montana & 1,024 & - & - & - & - & - & - & - & 2 & 3 \\
\hline Nevada & 2,839 & - & - & - & - & - & - & - & 3 & - \\
\hline New Mexico & 2,086 & - & - & - & - & - & - & - & 19 & 5 \\
\hline Utah & 2,943 & - & - & - & - & - & - & - & 1 & 1 \\
\hline Wyoming & 584 & - & - & - & - & - & - & - & - & 5 \\
\hline
\end{tabular}

See table footnotes on next page. 
TABLE 2a. (Continued) Number of reported cases of notifiable diseases, ${ }^{*}$ by region and reporting area — United States and U.S. territories, 2014

\begin{tabular}{|c|c|c|c|c|c|c|c|c|c|c|}
\hline \multirow[b]{3}{*}{ Area } & \multirow{3}{*}{$\begin{array}{c}\text { Total } \\
\text { resident } \\
\text { population } \\
\text { (in } \\
\text { thousands) }\end{array}$} & \multicolumn{9}{|c|}{ Arboviruses $^{\dagger}$} \\
\hline & & \multicolumn{2}{|c|}{$\begin{array}{l}\text { California } \\
\text { serogroup }\end{array}$} & \multirow{2}{*}{$\begin{array}{c}\begin{array}{c}\text { Eastern equine } \\
\text { encephalitis }\end{array} \\
\begin{array}{c}\text { Neuro- } \\
\text { invasive }\end{array}\end{array}$} & \multicolumn{2}{|c|}{ Powassan } & \multicolumn{2}{|c|}{$\begin{array}{c}\text { St. Louis } \\
\text { encephalitis }\end{array}$} & \multicolumn{2}{|c|}{ West Nile } \\
\hline & & $\begin{array}{l}\text { Neuro- } \\
\text { invasive }\end{array}$ & $\begin{array}{l}\text { Nonneuro- } \\
\text { invasive }\end{array}$ & & $\begin{array}{l}\text { Neuro- } \\
\text { invasive }\end{array}$ & $\begin{array}{l}\text { Nonneuro- } \\
\text { invasive }\end{array}$ & $\begin{array}{l}\text { Neuro- } \\
\text { invasive }\end{array}$ & $\begin{array}{l}\text { Nonneuro- } \\
\text { invasive }\end{array}$ & $\begin{array}{l}\text { Neuro- } \\
\text { invasive }\end{array}$ & $\begin{array}{l}\text { Nonneuro- } \\
\text { invasive }\end{array}$ \\
\hline Pacific & 51,992 & - & - & - & - & - & - & - & 575 & 247 \\
\hline Alaska & 737 & - & - & - & - & - & - & - & - & - \\
\hline California & 38,803 & - & - & - & - & - & - & - & 561 & 240 \\
\hline Hawaii & 1,420 & - & - & - & - & - & - & - & - & 1 \\
\hline Oregon & 3,970 & - & - & - & - & - & - & - & 7 & 1 \\
\hline Washington & 7,062 & - & - & - & - & - & - & - & 7 & 5 \\
\hline \multicolumn{11}{|l|}{ Territories } \\
\hline American Samoa & 55 & - & - & - & - & - & - & - & - & - \\
\hline C.N.M.I. & 51 & - & - & - & - & - & - & - & - & - \\
\hline Guam & 161 & - & - & - & - & - & - & - & - & - \\
\hline Puerto Rico & 3,621 & - & - & - & - & - & - & - & - & - \\
\hline U.S. Virgin Islands & 104 & - & - & - & - & - & - & - & - & - \\
\hline
\end{tabular}

* No cases of anthrax; dengue hemorrhagic fever; eastern equine encephalitis, nonneuroinvasive; poliomyelitis, paralytic; poliovirus infection, nonparalytic; severe acute respiratory syndrome-associated coronavirus disease (SARS-CoV); smallpox; Vancomycin-resistant Staphylococcus aureus (VRSA); western equine encephalitis virus disease, neuroinvasive and nonneuroinvasive; and yellow fever were reported in the United States during 2014.

† Totals reported to the Division of Vector-Borne Diseases (DVBD), National Center for Emerging and Zoonotic Infectious Diseases (NCEZID) (ArboNET Surveillance), as of July 1, 2015.

$\S$ California serogroup viral diseases for 2014 include LaCrosse virus, Jamestown Canyon virus and California serogroup viruses not specified. 
TABLE 2b. Number of reported cases of notifiable diseases,* by region and reporting area — United States and U.S. territories, 2014

\begin{tabular}{|c|c|c|c|c|c|c|c|c|}
\hline \multirow[b]{2}{*}{ Area } & \multicolumn{3}{|c|}{ Babesiosis } & \multicolumn{4}{|c|}{ Botulism } & \multirow[b]{2}{*}{ Brucellosis } \\
\hline & Total & Confirmed & Probable & Total & Foodborne & Infant & Other $^{\dagger}$ & \\
\hline United States & 1,760 & 1,472 & 288 & 161 & 15 & 127 & 19 & 92 \\
\hline New England & 1,007 & 902 & 105 & 1 & - & 1 & - & 3 \\
\hline Connecticut & 212 & 173 & 39 & - & - & - & - & - \\
\hline Maine & 42 & 34 & 8 & - & - & - & - & - \\
\hline Massachusetts & 537 & 510 & 27 & - & - & - & - & 3 \\
\hline New Hampshire & 41 & 36 & 5 & - & - & - & - & - \\
\hline Rhode Island & 172 & 148 & 24 & - & - & - & - & - \\
\hline Vermont & 3 & 1 & 2 & 1 & - & 1 & - & - \\
\hline Mid. Atlantic & 640 & 498 & 142 & 26 & 2 & 24 & - & 2 \\
\hline New Jersey & 169 & 133 & 36 & 10 & - & 10 & - & 1 \\
\hline New York (upstate) & 421 & 319 & 102 & 5 & 2 & 3 & - & - \\
\hline New York City & 50 & 46 & 4 & 2 & - & 2 & - & 1 \\
\hline Pennsylvania & $\mathrm{N}$ & $\mathrm{N}$ & $\mathrm{N}$ & 9 & - & 9 & - & - \\
\hline E.N. Central & 47 & 31 & 16 & 8 & 4 & 4 & - & 12 \\
\hline Illinois & 1 & 1 & - & 1 & 1 & - & - & 4 \\
\hline Indiana & - & - & - & 1 & 1 & - & - & - \\
\hline Michigan & 2 & 1 & 1 & 1 & - & 1 & - & 2 \\
\hline Ohio & 1 & - & 1 & 5 & 2 & 3 & - & 1 \\
\hline Wisconsin & 43 & 29 & 14 & - & - & - & - & 5 \\
\hline W.N. Central & 50 & 32 & 18 & 4 & - & 4 & - & 4 \\
\hline lowa & $\mathrm{N}$ & $\mathrm{N}$ & $\mathrm{N}$ & - & - & - & $\mathrm{N}$ & - \\
\hline Kansas & $\mathrm{N}$ & $\mathrm{N}$ & $\mathrm{N}$ & - & - & - & - & 2 \\
\hline Minnesota & 49 & 31 & 18 & 1 & - & 1 & - & 1 \\
\hline Missouri & $\mathrm{N}$ & $\mathrm{N}$ & $\mathrm{N}$ & 3 & - & 3 & - & - \\
\hline Nebraska & - & - & - & - & - & - & - & 1 \\
\hline North Dakota & - & - & - & - & - & - & - & - \\
\hline South Dakota & 1 & 1 & - & - & - & - & - & - \\
\hline S. Atlantic & 6 & 3 & 3 & 18 & - & 17 & 1 & 19 \\
\hline Delaware & 1 & 1 & - & 4 & - & 4 & - & - \\
\hline District of Columbia & $\mathrm{N}$ & $\mathrm{N}$ & $\mathrm{N}$ & 1 & - & 1 & - & 2 \\
\hline Florida & $\mathrm{N}$ & $\mathrm{N}$ & $\mathrm{N}$ & - & - & - & - & 3 \\
\hline Georgia & $\mathrm{N}$ & $\mathrm{N}$ & $\mathrm{N}$ & 2 & - & 2 & - & 7 \\
\hline Maryland & 2 & - & 2 & 10 & - & 9 & 1 & - \\
\hline North Carolina & $\mathrm{N}$ & $\mathrm{N}$ & $\mathrm{N}$ & - & - & - & - & 2 \\
\hline South Carolina & 3 & 2 & 1 & - & - & - & - & 1 \\
\hline Virginia & $\mathrm{N}$ & $\mathrm{N}$ & $\mathrm{N}$ & 1 & - & 1 & - & 1 \\
\hline West Virginia & - & - & - & - & - & - & - & 3 \\
\hline E.S. Central & 1 & - & 1 & 2 & - & 2 & - & 2 \\
\hline Alabama & 1 & - & 1 & - & - & - & - & - \\
\hline Kentucky & $\mathrm{N}$ & $\mathrm{N}$ & $\mathrm{N}$ & 1 & - & 1 & - & 1 \\
\hline Mississippi & $\mathrm{N}$ & $\mathrm{N}$ & $\mathrm{N}$ & - & - & - & - & - \\
\hline Tennessee & - & - & - & 1 & - & 1 & - & 1 \\
\hline W.S. Central & 1 & 1 & - & 11 & - & 8 & 3 & 16 \\
\hline Arkansas & $\mathrm{N}$ & $\mathrm{N}$ & $\mathrm{N}$ & 3 & - & 1 & 2 & - \\
\hline Louisiana & - & - & - & - & - & - & - & - \\
\hline Oklahoma & $\mathrm{N}$ & $\mathrm{N}$ & $\mathrm{N}$ & - & - & - & - & 1 \\
\hline Texas & 1 & 1 & - & 8 & - & 7 & 1 & 15 \\
\hline Mountain & - & - & - & 17 & 1 & 15 & 1 & 9 \\
\hline Arizona & $\mathrm{N}$ & $\mathrm{N}$ & $\mathrm{N}$ & 2 & - & 1 & 1 & 6 \\
\hline Colorado & $\mathrm{N}$ & $\mathrm{N}$ & $\mathrm{N}$ & 6 & 1 & 5 & - & 3 \\
\hline Idaho & $\mathrm{N}$ & $\mathrm{N}$ & $\mathrm{N}$ & - & - & - & - & - \\
\hline Montana & - & - & - & 1 & - & 1 & - & - \\
\hline Nevada & $\mathrm{N}$ & $\mathrm{N}$ & $\mathrm{N}$ & 1 & - & 1 & - & - \\
\hline New Mexico & $\mathrm{N}$ & $\mathrm{N}$ & $\mathrm{N}$ & 1 & - & 1 & - & - \\
\hline Utah & - & - & - & 6 & - & 6 & - & - \\
\hline Wyoming & - & - & - & - & - & - & - & - \\
\hline Pacific & 8 & 5 & 3 & 74 & 8 & 52 & 14 & 25 \\
\hline Alaska & $\mathrm{N}$ & $\mathrm{N}$ & $\mathrm{N}$ & 7 & 7 & - & - & - \\
\hline California & 3 & 2 & 1 & 63 & - & 49 & 14 & 20 \\
\hline Hawaii & $\mathrm{N}$ & $\mathrm{N}$ & $\mathrm{N}$ & - & - & - & - & 1 \\
\hline Oregon & 1 & - & 1 & 1 & 1 & - & - & 1 \\
\hline Washington & 4 & 3 & 1 & 3 & - & 3 & - & 3 \\
\hline
\end{tabular}

See table footnotes on next page. 
Morbidity and Mortality Weekly Report

TABLE 2b. (Continued) Number of reported cases of notifiable diseases, ${ }^{*}$ by region and reporting area — United States and U.S. territories, 2014

\begin{tabular}{|c|c|c|c|c|c|c|c|c|}
\hline \multirow[b]{2}{*}{ Area } & \multicolumn{3}{|c|}{ Babesiosis } & \multicolumn{4}{|c|}{ Botulism } & \multirow[b]{2}{*}{ Brucellosis } \\
\hline & Total & Confirmed & Probable & Total & Foodborne & Infant & Other $^{\dagger}$ & \\
\hline \multicolumn{9}{|l|}{ Territories } \\
\hline American Samoa & U & U & U & - & - & - & - & - \\
\hline C.N.M.I. & - & - & - & - & - & - & - & - \\
\hline Guam & - & - & - & - & - & - & - & - \\
\hline Puerto Rico & $\mathrm{N}$ & $\mathrm{N}$ & $\mathrm{N}$ & - & - & - & - & - \\
\hline U.S. Virgin Islands & $\mathrm{N}$ & $\mathrm{N}$ & $\mathrm{N}$ & - & - & - & - & - \\
\hline
\end{tabular}

* No cases of anthrax; dengue hemorrhagic fever; eastern equine encephalitis, nonneuroinvasive; poliomyelitis, paralytic; poliovirus infection, nonparalytic; severe acute respiratory syndrome-associated coronavirus disease (SARS-CoV); smallpox; Vancomycin-resistant Staphylococcus aureus (VRSA); western equine encephalitis virus disease, neuroinvasive and nonneuroinvasive; and yellow fever were reported in the United States during 2014.

$\dagger$ Includes cases reported as wound and unspecified botulism. 
TABLE 2c. Number of reported cases of notifiable diseases, ${ }^{*}$ by region and reporting area — United States and U.S. territories, 2014

\begin{tabular}{|c|c|c|c|c|c|c|c|c|}
\hline \multirow[b]{2}{*}{ Area } & \multirow[b]{2}{*}{ Chancroid $^{\dagger}$} & \multirow{2}{*}{$\begin{array}{l}\text { Chlamydia } \\
\text { trachomatis } \\
\text { infection }^{\dagger}\end{array}$} & \multirow[b]{2}{*}{ Cholera } & \multirow[b]{2}{*}{ Coccidioidomycosis ${ }^{\S}$} & \multicolumn{3}{|c|}{ Cryptosporidiosis } & \multirow[b]{2}{*}{ Cyclosporiasis } \\
\hline & & & & & Total & Confirmed & Probable & \\
\hline United States & 6 & $1,441,789$ & 5 & 8,232 & 8,682 & 5,565 & 3,117 & 398 \\
\hline New England & 1 & 48,355 & 1 & 5 & 318 & 282 & 36 & 26 \\
\hline Connecticut & - & 13,382 & - & $\mathrm{N}$ & 45 & 45 & - & 8 \\
\hline Maine & - & 3,530 & - & $\mathrm{N}$ & 51 & 34 & 17 & $\mathrm{~N}$ \\
\hline Massachusetts & 1 & 21,271 & 1 & - & 139 & 139 & - & 18 \\
\hline New Hampshire & - & 3,586 & - & 3 & 40 & 23 & 17 & - \\
\hline Rhode Island & - & 4,349 & - & 2 & 16 & 16 & - & - \\
\hline Vermont & - & 2,237 & - & $\mathrm{N}$ & 27 & 25 & 2 & - \\
\hline Mid. Atlantic & - & 179,254 & - & - & 785 & 609 & 176 & 53 \\
\hline New Jersey & - & 29,904 & - & $\mathrm{N}$ & 77 & 77 & - & 16 \\
\hline New York (upstate) & - & 38,845 & - & $\mathrm{N}$ & 237 & 230 & 7 & 14 \\
\hline New York City & - & 59,969 & - & $\mathrm{N}$ & 102 & 102 & - & 23 \\
\hline Pennsylvania & - & 50,536 & - & $\mathrm{N}$ & 369 & 200 & 169 & $\mathrm{~N}$ \\
\hline E.N. Central & - & 217,323 & - & 55 & 1,451 & 1,044 & 407 & 26 \\
\hline Illinois & - & 66,536 & - & $\mathrm{N}$ & 158 & 79 & 79 & 14 \\
\hline Indiana & - & 28,519 & - & $\mathrm{N}$ & 185 & 96 & 89 & 2 \\
\hline Michigan & - & 44,256 & - & 33 & 239 & 215 & 24 & 8 \\
\hline Ohio & - & 54,858 & - & 16 & 324 & 109 & 215 & 1 \\
\hline Wisconsin & - & 23,154 & - & 6 & 545 & 545 & - & 1 \\
\hline W.N. Central & - & 85,924 & 1 & 118 & 1,248 & 666 & 582 & 10 \\
\hline lowa & - & 11,804 & - & $N$ & 264 & 61 & 203 & - \\
\hline Kansas & - & 11,116 & - & $\mathrm{N}$ & 67 & 22 & 45 & 1 \\
\hline Minnesota & - & 19,907 & 1 & 90 & 338 & 244 & 94 & 5 \\
\hline Missouri & - & 27,981 & - & 19 & 167 & 81 & 86 & 1 \\
\hline Nebraska & - & 7,499 & - & 4 & 111 & 87 & 24 & 3 \\
\hline North Dakota & - & 3,451 & - & 5 & 148 & 143 & 5 & $\mathrm{~N}$ \\
\hline South Dakota & - & 4,166 & - & $\mathrm{N}$ & 153 & 28 & 125 & - \\
\hline S. Atlantic & - & 289,330 & 2 & 11 & 2,627 & 1,488 & 1,139 & 70 \\
\hline Delaware & - & 4,473 & - & - & 8 & 6 & 2 & - \\
\hline District of Columbia & - & 5,293 & - & 1 & 5 & 5 & - & - \\
\hline Florida & - & 84,194 & 2 & $\mathrm{~N}$ & 1,905 & 1,031 & 874 & 33 \\
\hline Georgia & - & 51,945 & - & $\mathrm{N}$ & 240 & 240 & - & 6 \\
\hline Maryland & - & 27,424 & - & 10 & 79 & 47 & 32 & 4 \\
\hline North Carolina & - & 47,147 & - & $\mathrm{N}$ & 166 & 85 & 81 & 4 \\
\hline South Carolina & - & 28,087 & - & $\mathrm{N}$ & 63 & 41 & 22 & 18 \\
\hline Virginia & - & 36,048 & - & $\mathrm{N}$ & 152 & 32 & 120 & 4 \\
\hline West Virginia & - & 4,719 & - & $\mathrm{N}$ & 9 & 1 & 8 & 1 \\
\hline E.S. Central & - & 97,072 & - & - & 411 & 282 & 129 & 1 \\
\hline Alabama & - & 29,010 & - & $\mathrm{N}$ & 147 & 67 & 80 & $\mathrm{~N}$ \\
\hline Kentucky & - & 17,664 & - & $\mathrm{N}$ & 80 & 50 & 30 & $\mathrm{~N}$ \\
\hline Mississippi & - & 19,605 & - & $\mathrm{N}$ & 66 & 66 & - & $\mathrm{N}$ \\
\hline Tennessee & - & 30,793 & - & $\mathrm{N}$ & 118 & 99 & 19 & 1 \\
\hline W.S. Central & 1 & 196,441 & - & 3 & 804 & 436 & 368 & 201 \\
\hline Arkansas & - & 15,605 & - & - & 56 & 55 & 1 & 1 \\
\hline Louisiana & - & 28,955 & - & 3 & 244 & 107 & 137 & - \\
\hline Oklahoma & - & 20,662 & - & $\mathrm{N}$ & 88 & 23 & 65 & $N$ \\
\hline Texas & 1 & 131,219 & - & $\mathrm{N}$ & 416 & 251 & 165 & 200 \\
\hline Mountain & - & 97,489 & 1 & 5,792 & 487 & 361 & 126 & 6 \\
\hline Arizona & - & 32,397 & - & 5,624 & 46 & 33 & 13 & 2 \\
\hline Colorado & - & 21,863 & 1 & $\mathrm{~N}$ & 75 & 52 & 23 & 1 \\
\hline Idaho & - & 5,442 & - & $\mathrm{N}$ & 100 & 87 & 13 & $\mathrm{~N}$ \\
\hline Montana & - & 4,193 & - & 10 & 66 & 57 & 9 & 2 \\
\hline Nevada & - & 11,841 & - & 70 & 16 & 10 & 6 & $\mathrm{~N}$ \\
\hline New Mexico & - & 11,558 & - & 40 & 86 & 80 & 6 & - \\
\hline Utah & - & 8,223 & - & 46 & 70 & 16 & 54 & 1 \\
\hline Wyoming & - & 1,972 & - & 2 & 28 & 26 & 2 & - \\
\hline Pacific & 4 & 230,601 & - & 2,248 & 551 & 397 & 154 & 5 \\
\hline Alaska & - & 5,789 & - & $\mathrm{N}$ & 4 & 3 & 1 & - \\
\hline California & 4 & 176,308 & - & 2,243 & 357 & 346 & 11 & 2 \\
\hline Hawaii & - & 6,419 & - & $\mathrm{N}$ & 3 & 3 & - & - \\
\hline Oregon & - & 15,508 & - & 5 & 112 & 10 & 102 & 1 \\
\hline Washington & - & 26,577 & - & $\mathrm{N}$ & 75 & 35 & 40 & 2 \\
\hline
\end{tabular}

See table footnotes on next page. 
Morbidity and Mortality Weekly Report

TABLE 2c. (Continued) Number of reported cases of notifiable diseases, ${ }^{*}$ by region and reporting area - United States and U.S. territories, 2014

\begin{tabular}{|c|c|c|c|c|c|c|c|c|}
\hline \multirow[b]{2}{*}{ Area } & \multirow[b]{2}{*}{ Chancroid $^{\dagger}$} & \multirow{2}{*}{$\begin{array}{l}\text { Chlamydia } \\
\text { trachomatis }^{\text {infection }}{ }^{\dagger}\end{array}$} & \multirow[b]{2}{*}{ Cholera } & \multirow[b]{2}{*}{ Coccidioidomycosis ${ }^{\S}$} & \multicolumn{3}{|c|}{ Cryptosporidiosis } & \multirow[b]{2}{*}{ Cyclosporiasis } \\
\hline & & & & & Total & Confirmed & Probable & \\
\hline \multicolumn{9}{|l|}{ Territories } \\
\hline American Samoa & - & - & - & $\mathrm{N}$ & $\mathrm{N}$ & $\mathrm{N}$ & $\mathrm{N}$ & $\mathrm{N}$ \\
\hline C.N.M.I. & - & - & - & - & - & - & - & - \\
\hline Guam & - & 839 & - & - & - & - & - & - \\
\hline Puerto Rico & - & 4,899 & - & $\mathrm{N}$ & - & - & - & - \\
\hline U.S. Virgin Islands & - & 791 & - & - & - & - & - & - \\
\hline
\end{tabular}

* No cases of anthrax; dengue hemorrhagic fever; eastern equine encephalitis, nonneuroinvasive; poliomyelitis, paralytic; poliovirus infection, nonparalytic; severe acute respiratory syndrome-associated coronavirus disease (SARS-CoV); smallpox; Vancomycin-resistant Staphylococcus aureus (VRSA); western equine encephalitis virus disease, neuroinvasive and nonneuroinvasive; and yellow fever were reported in the United States during 2014.

${ }^{\dagger}$ Totals reported to the Division of STD Prevention, NCHHSTP, as of June 10, 2015.

$\S$ Notifiable in $<25$ states. 
TABLE 2d. Number of reported cases of notifiable diseases,* by region and reporting area — United States and U.S. territories, 2014

\begin{tabular}{|c|c|c|c|c|c|c|}
\hline \multirow[b]{2}{*}{ Area } & \multirow{2}{*}{$\frac{\text { Dengue }^{\dagger} \text { Virus Infection }}{\text { Dengue Fever }}$} & \multirow[b]{2}{*}{ Diphtheria } & \multirow{2}{*}{$\begin{array}{c}\text { Anaplasma } \\
\text { phagocytophilum }\end{array}$} & \multicolumn{3}{|c|}{ Ehrlichiosis/Anaplasmosis } \\
\hline & & & & Ehrlichia chaffeensis & Ehrlichia ewingii & Undetermined \\
\hline United States & 680 & 1 & 2,800 & 1,475 & 17 & 196 \\
\hline New England & 35 & - & 1,182 & 60 & - & 10 \\
\hline Connecticut & 3 & - & 75 & - & - & - \\
\hline Maine & 1 & - & 191 & 8 & - & 6 \\
\hline Massachusetts & 17 & - & 621 & 20 & - & 1 \\
\hline New Hampshire & 5 & - & 131 & 7 & - & 2 \\
\hline Rhode Island & 5 & - & 97 & 24 & - & - \\
\hline Vermont & 4 & - & 67 & 1 & - & 1 \\
\hline Mid. Atlantic & 160 & - & 547 & 177 & - & 26 \\
\hline New Jersey & 84 & - & 69 & 54 & - & 10 \\
\hline New York (upstate) & 28 & - & 421 & 109 & - & 11 \\
\hline New York City & 42 & - & 32 & 9 & - & - \\
\hline Pennsylvania & 6 & - & 25 & 5 & - & 5 \\
\hline E.N. Central & 34 & 1 & 507 & 62 & - & 96 \\
\hline Illinois & 7 & - & 18 & 47 & - & - \\
\hline Indiana & 5 & - & - & - & - & 49 \\
\hline Michigan & 5 & - & 4 & 3 & - & - \\
\hline Ohio & 9 & 1 & 1 & 4 & - & 1 \\
\hline Wisconsin & 8 & - & 484 & 8 & - & 46 \\
\hline W.N. Central & 10 & - & 483 & 386 & 12 & 39 \\
\hline lowa & 4 & - & $\mathrm{N}$ & $\mathrm{N}$ & $\mathrm{N}$ & $\mathrm{N}$ \\
\hline Kansas & 1 & - & 4 & 46 & 2 & 3 \\
\hline Minnesota & 3 & - & 448 & 5 & 1 & 17 \\
\hline Missouri & 2 & - & 24 & 328 & 9 & 19 \\
\hline Nebraska & - & - & 1 & 6 & - & - \\
\hline North Dakota & - & - & 6 & 1 & - & - \\
\hline South Dakota & - & - & - & - & - & - \\
\hline S. Atlantic & 126 & - & 41 & 299 & 3 & 10 \\
\hline Delaware & 1 & - & 2 & 22 & - & - \\
\hline District of Columbia & 2 & - & - & - & - & 1 \\
\hline Florida & 84 & - & 7 & 29 & - & - \\
\hline Georgia & 4 & - & 1 & 14 & - & 1 \\
\hline Maryland & 8 & - & 2 & 38 & 1 & - \\
\hline North Carolina & 8 & - & 12 & 73 & - & - \\
\hline South Carolina & 2 & - & - & 8 & - & - \\
\hline Virginia & 16 & - & 15 & 112 & 2 & 8 \\
\hline West Virginia & 1 & - & 2 & 3 & - & - \\
\hline E.S. Central & 8 & - & 11 & 163 & 1 & 12 \\
\hline Alabama & 3 & - & 7 & 10 & - & 2 \\
\hline Kentucky & 1 & - & - & 62 & - & - \\
\hline Mississippi & 2 & - & 1 & 4 & - & - \\
\hline Tennessee & 2 & - & 3 & 87 & 1 & 10 \\
\hline W.S. Central & 41 & - & 24 & 328 & 1 & - \\
\hline Arkansas & 4 & - & 15 & 236 & 1 & - \\
\hline Louisiana & 3 & - & 2 & 3 & - & - \\
\hline Oklahoma & - & - & 4 & 77 & - & - \\
\hline Texas & 34 & - & 3 & 12 & - & - \\
\hline Mountain & 113 & - & - & - & - & 1 \\
\hline Arizona & 97 & - & - & - & - & 1 \\
\hline Colorado & 10 & - & $\mathrm{N}$ & $\mathrm{N}$ & $\mathrm{N}$ & $\mathrm{N}$ \\
\hline Idaho & 1 & - & $\mathrm{N}$ & $\mathrm{N}$ & $\mathrm{N}$ & $\mathrm{N}$ \\
\hline Montana & 2 & - & - & - & - & - \\
\hline Nevada & 3 & - & - & - & - & - \\
\hline New Mexico & - & - & $\mathrm{N}$ & $\mathrm{N}$ & $\mathrm{N}$ & $\mathrm{N}$ \\
\hline Utah & - & - & - & - & - & - \\
\hline Wyoming & - & - & - & - & - & - \\
\hline Pacific & 153 & - & 5 & - & - & 2 \\
\hline Alaska & 4 & - & $\mathrm{N}$ & $\mathrm{N}$ & $\mathrm{N}$ & $\mathrm{N}$ \\
\hline California & 130 & - & 5 & - & - & 2 \\
\hline Hawaii & 10 & - & $\mathrm{N}$ & $\mathrm{N}$ & $\mathrm{N}$ & - \\
\hline Oregon & - & - & - & - & - & $\mathrm{N}$ \\
\hline Washington & 9 & - & - & - & - & - \\
\hline
\end{tabular}

See table footnotes on next page. 
TABLE 2d. (Continued) Number of reported cases of notifiable diseases, ${ }^{*}$ by region and reporting area — United States and U.S. territories, 2014

\begin{tabular}{|c|c|c|c|c|c|c|}
\hline \multirow[b]{2}{*}{ Area } & \multirow{2}{*}{$\frac{\text { Dengue }^{\dagger} \text { Virus Infection }}{\text { Dengue Fever }}$} & \multirow[b]{2}{*}{ Diphtheria } & \multirow{2}{*}{$\begin{array}{c}\text { Anaplasma } \\
\text { phagocytophilum }\end{array}$} & \multicolumn{3}{|c|}{ Ehrlichiosis/Anaplasmosis } \\
\hline & & & & Ehrlichia chaffeensis & Ehrlichia ewingii & Undetermined \\
\hline \multicolumn{7}{|l|}{ Territories } \\
\hline American Samoa & - & - & $\mathrm{N}$ & $\mathrm{N}$ & $\mathrm{N}$ & $\mathrm{N}$ \\
\hline C.N.M.I. & - & - & - & - & - & - \\
\hline Guam & - & - & $\mathrm{N}$ & $\mathrm{N}$ & $\mathrm{N}$ & $\mathrm{N}$ \\
\hline Puerto Rico & 525 & - & $\mathrm{N}$ & $\mathrm{N}$ & $\mathrm{N}$ & $\mathrm{N}$ \\
\hline U.S. Virgin Islands & 19 & - & - & - & - & - \\
\hline
\end{tabular}

* No cases of anthrax; dengue hemorrhagic fever; eastern equine encephalitis, nonneuroinvasive; poliomyelitis, paralytic; poliovirus infection, nonparalytic; severe acute respiratory syndrome-associated coronavirus disease (SARS-CoV); smallpox; Vancomycin-resistant Staphylococcus aureus (VRSA); western equine encephalitis virus disease, neuroinvasive and nonneuroinvasive; and yellow fever were reported in the United States during 2014.

† Total number of reported laboratory-positive dengue cases including all confirmed cases [by antidengue virus (DENV) molecular diagnostic methods or seroconversion of anti-DENV IgM] and all probable cases (by a single, positive anti-DENV IgM). Totals reported to the Division of Vector-Borne Diseases (DVBD), National Center for Emerging and Zoonotic Infectious Diseases (NCEZID) (ArboNET Surveillance), as of July 1, 2015. 


\begin{tabular}{|c|c|c|c|c|c|c|c|c|}
\hline \multirow[b]{3}{*}{ Area } & \multirow[b]{3}{*}{ Giardiasis } & \multirow[b]{3}{*}{ Gonorrhea $^{\dagger}$} & \multicolumn{5}{|c|}{ Haemophilus influenzae, invasive disease } & \multirow[b]{3}{*}{$\begin{array}{l}\text { Hansen's disease } \\
\text { (leprosy) }\end{array}$} \\
\hline & & & \multirow[b]{2}{*}{$\begin{array}{l}\text { All ages, } \\
\text { serotypes }\end{array}$} & \multicolumn{4}{|c|}{ Age $<5$ Years } & \\
\hline & & & & Serotype b & Nontypeable & Non-b serotype & $\begin{array}{l}\text { Unknown } \\
\text { serotype }\end{array}$ & \\
\hline United States & 14,554 & 350,062 & 3,541 & 40 & 128 & 38 & 266 & 88 \\
\hline New England & 1,361 & 7,287 & 240 & 2 & 8 & 2 & 10 & 3 \\
\hline Connecticut & 219 & 2,333 & 60 & - & - & - & 9 & - \\
\hline Maine & 154 & 237 & 21 & 1 & 2 & - & - & $\mathrm{N}$ \\
\hline Massachusetts & 709 & 3,817 & 104 & 1 & 4 & 1 & - & 3 \\
\hline New Hampshire & 97 & 226 & 24 & - & 1 & 1 & - & - \\
\hline Rhode Island & 45 & 590 & 16 & - & 1 & - & 1 & - \\
\hline Vermont & 137 & 84 & 15 & - & - & - & - & $\mathrm{N}$ \\
\hline Mid. Atlantic & 2,931 & 40,104 & 598 & 9 & 15 & 2 & 31 & 10 \\
\hline New Jersey & 384 & 6,636 & 149 & - & - & - & 14 & - \\
\hline New York (upstate) & 951 & 6,616 & 148 & 3 & 5 & - & 1 & $\mathrm{~N}$ \\
\hline New York City & 874 & 14,142 & 120 & - & - & - & 12 & 10 \\
\hline Pennsylvania & 722 & 12,710 & 181 & 6 & 10 & 2 & 4 & - \\
\hline E.N. Central & 1,562 & 53,262 & 589 & 7 & 33 & 13 & 18 & 4 \\
\hline Illinois & $\mathrm{N}$ & 15,970 & 164 & - & 4 & 5 & 5 & - \\
\hline Indiana & 167 & 7,289 & 102 & 2 & 5 & 1 & 3 & - \\
\hline Michigan & 506 & 9,688 & 106 & 4 & 5 & 5 & - & 1 \\
\hline Ohio & 385 & 16,237 & 128 & - & 15 & 2 & 4 & 2 \\
\hline Wisconsin & 504 & 4,078 & 89 & 1 & 4 & - & 6 & 1 \\
\hline W.N. Central & 1,501 & 18,714 & 304 & 2 & 1 & 1 & 41 & 2 \\
\hline lowa & 205 & 1,641 & 4 & 1 & - & - & - & - \\
\hline Kansas & 104 & 2,568 & 43 & 1 & 1 & - & 8 & - \\
\hline Minnesota & 662 & 4,073 & 127 & - & - & - & 18 & - \\
\hline Missouri & 228 & 7,387 & 97 & - & - & - & 8 & 2 \\
\hline Nebraska & 131 & 1,459 & 25 & - & - & - & 6 & - \\
\hline North Dakota & 39 & 694 & 8 & - & - & 1 & 1 & $\mathrm{~N}$ \\
\hline South Dakota & 132 & 892 & - & - & - & - & - & - \\
\hline S. Atlantic & 2,663 & 75,743 & 854 & 4 & 14 & 10 & 62 & 13 \\
\hline Delaware & 24 & 1,279 & 16 & - & - & - & 4 & - \\
\hline District of Columbia & 78 & 1,883 & 10 & - & - & 1 & 1 & - \\
\hline Florida & 1,165 & 20,944 & 259 & - & - & - & 32 & 10 \\
\hline Georgia & 656 & 13,770 & 138 & 1 & 5 & 8 & 4 & 1 \\
\hline Maryland & 268 & 6,108 & 85 & 1 & 1 & - & 2 & 1 \\
\hline North Carolina & $\mathrm{N}$ & 14,415 & 146 & - & - & - & 16 & - \\
\hline South Carolina & 150 & 8,253 & 63 & 1 & 1 & - & - & - \\
\hline Virginia & 256 & 8,250 & 89 & - & 7 & 1 & 1 & 1 \\
\hline West Virginia & 66 & 841 & 48 & 1 & - & - & 2 & $\mathrm{~N}$ \\
\hline E.S. Central & 182 & 24,854 & 239 & - & 18 & 5 & 17 & 5 \\
\hline Alabama & 182 & 7,677 & 65 & - & 7 & 3 & 3 & - \\
\hline Kentucky & $\mathrm{N}$ & 4,353 & 37 & - & 1 & 1 & 6 & 1 \\
\hline Mississippi & $\mathrm{N}$ & 5,625 & 36 & - & - & - & 5 & 4 \\
\hline Tennessee & $\mathrm{N}$ & 7,199 & 101 & - & 10 & 1 & 3 & - \\
\hline W.S. Central & 393 & 55,000 & 204 & 7 & 9 & - & 8 & 27 \\
\hline Arkansas & 113 & 4,539 & 50 & - & 4 & - & - & 7 \\
\hline Louisiana & 280 & 9,002 & 46 & - & - & - & 6 & 1 \\
\hline Oklahoma & $\mathrm{N}$ & 6,137 & 96 & 1 & 5 & - & 2 & $\mathrm{~N}$ \\
\hline Texas & $\mathrm{N}$ & 35,322 & 12 & 6 & $\mathrm{~N}$ & $\mathrm{~N}$ & $\mathrm{~N}$ & 19 \\
\hline Mountain & 1,111 & 18,788 & 330 & 5 & 25 & 2 & 26 & 4 \\
\hline Arizona & 119 & 7,750 & 101 & - & 8 & - & 12 & - \\
\hline Colorado & 332 & 3,170 & 66 & - & 4 & 2 & 2 & 1 \\
\hline Idaho & 154 & 443 & 18 & - & - & - & - & - \\
\hline Montana & 89 & 434 & 14 & 1 & - & - & 1 & - \\
\hline Nevada & 65 & 3,188 & 17 & - & 2 & - & 1 & 1 \\
\hline New Mexico & 101 & 2,246 & 49 & 2 & 4 & - & 6 & - \\
\hline Utah & 225 & 1,441 & 59 & 2 & 7 & - & 3 & 2 \\
\hline Wyoming & 26 & 116 & 6 & - & - & - & 1 & - \\
\hline
\end{tabular}

See table footnotes on next page. 
TABLE 2e. (Continued) Number of reported cases of notifiable diseases, ${ }^{*}$ by region and reporting area — United States and U.S. territories, 2014

\begin{tabular}{|c|c|c|c|c|c|c|c|c|}
\hline \multirow[b]{3}{*}{ Area } & \multirow[b]{3}{*}{ Giardiasis } & \multirow[b]{3}{*}{ Gonorrhea $^{\dagger}$} & \multicolumn{5}{|c|}{ Haemophilus influenzae, invasive disease } & \multirow[b]{3}{*}{$\begin{array}{l}\text { Hansen's disease } \\
\text { (leprosy) }\end{array}$} \\
\hline & & & \multirow[b]{2}{*}{$\begin{array}{l}\text { All ages, } \\
\text { serotypes }\end{array}$} & \multicolumn{4}{|c|}{ Age $<5$ Years } & \\
\hline & & & & Serotype b & Nontypeable & Non-b serotype & $\begin{array}{l}\text { Unknown } \\
\text { serotype }\end{array}$ & \\
\hline Pacific & 2,850 & 56,310 & 183 & 4 & 5 & 3 & 53 & 20 \\
\hline Alaska & 89 & 1,341 & 25 & - & 4 & - & 3 & - \\
\hline California & 1,852 & 45,408 & 42 & - & - & - & 35 & 6 \\
\hline Hawaii & 43 & 1,020 & 23 & - & - & - & 6 & 14 \\
\hline Oregon & 351 & 2,320 & 84 & - & 1 & - & 7 & $\mathrm{~N}$ \\
\hline Washington & 515 & 6,221 & 9 & 4 & - & 3 & 2 & $\mathrm{~N}$ \\
\hline \multicolumn{9}{|l|}{ Territories } \\
\hline American Samoa & - & - & - & - & - & - & - & - \\
\hline C.N.M.I. & - & - & - & - & - & - & - & - \\
\hline Guam & 1 & 99 & - & - & - & - & - & 13 \\
\hline Puerto Rico & 31 & 454 & 3 & - & - & 1 & - & 2 \\
\hline U.S. Virgin Islands & - & 84 & $\mathrm{~N}$ & $\mathrm{~N}$ & $\mathrm{~N}$ & $\mathrm{~N}$ & $\mathrm{~N}$ & - \\
\hline
\end{tabular}

* No cases of anthrax; dengue hemorrhagic fever; eastern equine encephalitis, nonneuroinvasive; poliomyelitis, paralytic; poliovirus infection, nonparalytic; severe acute respiratory syndrome-associated coronavirus disease (SARS-CoV); smallpox; Vancomycin-resistant Staphylococcus aureus (VRSA); western equine encephalitis virus disease, neuroinvasive and nonneuroinvasive; and yellow fever were reported in the United States during 2014.

† Totals reported to the Division of STD Prevention, NCHHSTP, as of June 10, 2015. 
TABLE 2f. Number of reported cases of notifiable diseases, ${ }^{*}$ by region and reporting area — United States and U.S. territories, 2014

\begin{tabular}{|c|c|c|c|c|c|c|c|c|}
\hline Area & $\begin{array}{l}\text { Hantavirus } \\
\text { pulmonary } \\
\text { syndrome }\end{array}$ & $\begin{array}{l}\text { Hemolytic uremic } \\
\text { syndrome } \\
\text { postdiarrheal }\end{array}$ & $\begin{array}{l}\text { Hepatitis A, } \\
\text { acute }\end{array}$ & $\begin{array}{l}\text { Hepatitis B, } \\
\text { acute }\end{array}$ & $\begin{array}{l}\text { Hepatitis B, } \\
\text { chronic }^{\dagger}\end{array}$ & $\begin{array}{l}\text { Hepatitis B } \\
\text { perinatal } \\
\text { infection }\end{array}$ & $\begin{array}{l}\text { Hepatitis C, } \\
\text { acute }\end{array}$ & $\begin{array}{c}\text { Hepatitis C, } \\
\text { past or present }\end{array}$ \\
\hline United States & 32 & 250 & 1,239 & 2,791 & 12,400 & 47 & 2,204 & 162,863 \\
\hline New England & - & 11 & 88 & 59 & 411 & 1 & 272 & 11,227 \\
\hline Connecticut & $\mathrm{N}$ & 4 & 23 & 9 & 72 & - & 9 & 3,263 \\
\hline Maine & - & 1 & 8 & 12 & 44 & - & 31 & 1,423 \\
\hline Massachusetts & - & 6 & 43 & 30 & 233 & 1 & 228 & 5,639 \\
\hline New Hampshire & - & - & 5 & 4 & 28 & - & $\mathrm{N}$ & $\mathrm{N}$ \\
\hline Rhode Island & - & - & 8 & $\mathrm{U}$ & U & - & $U$ & U \\
\hline Vermont & - & - & 1 & 4 & 34 & - & 4 & 902 \\
\hline Mid. Atlantic & - & 7 & 191 & 240 & 3,669 & 11 & 308 & 33,947 \\
\hline New Jersey & - & 3 & 59 & 77 & 487 & - & 113 & 7,765 \\
\hline New York (upstate) & - & 3 & 38 & 38 & 496 & 1 & 113 & 8,448 \\
\hline New York City & - & 1 & 46 & 57 & 1,759 & 6 & 13 & 7,339 \\
\hline Pennsylvania & - & - & 48 & 68 & 927 & 4 & 69 & 10,395 \\
\hline E.N. Central & - & 33 & 186 & 416 & 1,662 & 5 & 381 & 32,104 \\
\hline Illinois & - & 4 & 82 & 58 & 972 & - & 27 & 8,777 \\
\hline Indiana & - & 7 & 20 & 126 & U & - & 122 & U \\
\hline Michigan & - & 6 & 45 & 50 & 475 & 2 & 78 & 7,572 \\
\hline Ohio & - & 9 & 32 & 171 & 214 & 2 & 105 & 15,755 \\
\hline Wisconsin & - & 7 & 7 & 11 & 1 & 1 & 49 & - \\
\hline W.N. Central & 4 & 34 & 79 & 78 & 1,013 & 2 & 76 & 12,033 \\
\hline lowa & 2 & 6 & 12 & 9 & 66 & - & U & - \\
\hline Kansas & - & 10 & 7 & 11 & 116 & - & 28 & 1,560 \\
\hline Minnesota & - & 10 & 19 & 16 & 197 & - & 40 & 1,899 \\
\hline Missouri & - & 6 & 20 & 31 & 431 & 2 & 6 & 6,278 \\
\hline Nebraska & - & 1 & 9 & 8 & 110 & - & 2 & 926 \\
\hline North Dakota & 2 & - & 9 & - & 83 & - & - & 848 \\
\hline South Dakota & - & 1 & 3 & 3 & 10 & - & - & 522 \\
\hline S. Atlantic & - & 31 & 225 & 848 & 2,874 & 4 & 423 & 49,338 \\
\hline Delaware & - & - & 1 & 8 & 88 & - & U & U \\
\hline District of Columbia & - & - & $U$ & U & U & U & U & U \\
\hline Florida & - & 7 & 90 & 313 & 1,137 & 1 & 93 & 22,253 \\
\hline Georgia & - & 7 & 24 & 103 & $\mathrm{~N}$ & - & 57 & 4,237 \\
\hline Maryland & - & 6 & 27 & 40 & 498 & - & 42 & 7,041 \\
\hline North Carolina & - & 4 & 38 & 100 & 447 & 2 & 111 & $\mathrm{~N}$ \\
\hline South Carolina & - & 1 & 6 & 37 & 145 & - & 4 & 3,586 \\
\hline Virginia & - & 6 & 27 & 61 & 341 & 1 & 54 & 5,590 \\
\hline West Virginia & - & - & 12 & 186 & 218 & - & 62 & 6,631 \\
\hline E.S. Central & - & 21 & 49 & 561 & 625 & 2 & 334 & - \\
\hline Alabama & $\mathrm{N}$ & 1 & 15 & 117 & $\mathrm{~N}$ & - & 35 & $\mathrm{~N}$ \\
\hline Kentucky & - & 4 & 19 & 164 & $\mathrm{~N}$ & - & 176 & $\mathrm{~N}$ \\
\hline Mississippi & $\mathrm{N}$ & 2 & 3 & 48 & $\mathrm{~N}$ & $\mathrm{~N}$ & U & - \\
\hline Tennessee & - & 14 & 12 & 232 & 625 & 2 & 123 & N \\
\hline W.S. Central & 6 & 37 & 148 & 294 & 211 & 5 & 127 & 2,657 \\
\hline Arkansas & - & 8 & 2 & 28 & $\mathrm{~N}$ & - & 13 & $\mathrm{~N}$ \\
\hline Louisiana & - & 2 & 5 & 87 & 125 & 1 & 22 & 2,116 \\
\hline Oklahoma & 1 & 21 & 17 & 57 & 86 & 1 & 45 & 541 \\
\hline Texas & 5 & 6 & 124 & 122 & $\mathrm{~N}$ & 3 & 47 & $\mathrm{~N}$ \\
\hline Mountain & 19 & 30 & 86 & 100 & 449 & - & 112 & 10,299 \\
\hline Arizona & 5 & - & 29 & 31 & 98 & - & U & U \\
\hline Colorado & 4 & 6 & 23 & 29 & 144 & - & 33 & 3,644 \\
\hline Idaho & - & 10 & 7 & 6 & 51 & - & 6 & 932 \\
\hline Montana & 1 & 5 & 5 & - & 26 & - & 13 & 1,413 \\
\hline Nevada & - & 1 & 5 & 21 & $\mathrm{~N}$ & - & 6 & $\mathrm{~N}$ \\
\hline New Mexico & 6 & - & 8 & 2 & 50 & - & 16 & 2,316 \\
\hline Utah & 2 & 8 & 8 & 11 & 34 & - & 38 & 1,492 \\
\hline Wyoming & 1 & - & 1 & U & 46 & - & U & 502 \\
\hline Pacific & 3 & 46 & 187 & 195 & 1,486 & 17 & 171 & 11,258 \\
\hline Alaska & - & - & 1 & 3 & U & - & $\mathrm{N}$ & - \\
\hline California & 1 & 38 & 142 & 110 & 1,114 & 14 & 73 & 1,317 \\
\hline Hawaii & - & 2 & 5 & 6 & 182 & $\mathrm{~N}$ & 1 & 11 \\
\hline Oregon & 1 & 6 & 13 & 32 & 97 & - & 15 & 5,002 \\
\hline Washington & 1 & - & 26 & 44 & 93 & 3 & 82 & 4,928 \\
\hline
\end{tabular}

See table footnotes on next page. 
TABLE 2f. (Continued) Number of reported cases of notifiable diseases, ${ }^{*}$ by region and reporting area - United States and U.S. territories, 2014

\begin{tabular}{|c|c|c|c|c|c|c|c|c|}
\hline Area & $\begin{array}{l}\text { Hantavirus } \\
\text { pulmonary } \\
\text { syndrome }\end{array}$ & $\begin{array}{l}\text { Hemolytic uremic } \\
\text { syndrome } \\
\text { postdiarrheal }\end{array}$ & $\begin{array}{l}\text { Hepatitis A, } \\
\text { acute }\end{array}$ & $\begin{array}{l}\text { Hepatitis B, } \\
\text { acute }\end{array}$ & $\begin{array}{l}\text { Hepatitis B, } \\
\text { chronic }^{\dagger}\end{array}$ & $\begin{array}{l}\text { Hepatitis B } \\
\text { perinatal } \\
\text { infection }\end{array}$ & $\begin{array}{l}\text { Hepatitis C, } \\
\text { acute }\end{array}$ & $\begin{array}{c}\text { Hepatitis C, } \\
\text { past or present }{ }^{\dagger}\end{array}$ \\
\hline \multicolumn{9}{|l|}{ Territories } \\
\hline American Samoa & $\mathrm{N}$ & $\mathrm{N}$ & - & - & $\mathrm{N}$ & - & - & - \\
\hline C.N.M.I. & - & - & - & - & - & - & - & - \\
\hline Guam & $\mathrm{N}$ & - & 5 & 9 & 47 & - & 5 & 63 \\
\hline Puerto Rico & - & $\mathrm{N}$ & 8 & 19 & 5 & - & $\mathrm{N}$ & 558 \\
\hline U.S. Virgin Islands & - & $\mathrm{N}$ & - & - & - & - & - & - \\
\hline
\end{tabular}

* No cases of anthrax; dengue hemorrhagic fever; eastern equine encephalitis, nonneuroinvasive; poliomyelitis, paralytic; poliovirus infection, nonparalytic; severe acute respiratory syndrome-associated coronavirus disease (SARS-CoV); smallpox; Vancomycin-resistant Staphylococcus aureus (VRSA); western equine encephalitis virus disease, neuroinvasive and nonneuroinvasive; and yellow fever were reported in the United States during 2014.

${ }^{\dagger}$ Reported cases of chronic hepatitis B and hepatitis C past or present might not reflect unique case reports and might include both confirmed and probable case reports. 
TABLE 2g. Number of reported cases of notifiable diseases, ${ }^{*}$ by region and reporting area — United States and U.S. territories, 2014

\begin{tabular}{|c|c|c|c|c|c|c|c|}
\hline \multirow[b]{2}{*}{ Area } & \multirow{2}{*}{$\begin{array}{c}\text { HIV } \\
\text { diagnoses }\end{array}$} & \multirow{2}{*}{$\begin{array}{l}\text { Influenza-associated } \\
\text { pediatric mortality }\end{array}$} & \multicolumn{2}{|c|}{ Invasive pneumococcal disease $\mathrm{e}^{\S}$} & \multirow[b]{2}{*}{ Legionellosis } & \multirow[b]{2}{*}{ Leptospirosis } & \multirow[b]{2}{*}{ Listeriosis } \\
\hline & & & All ages & Age $<5$ years & & & \\
\hline United States & 35,606 & 141 & 15,356 & 1,065 & 5,166 & 38 & 769 \\
\hline New England & 887 & 3 & 1,136 & 51 & 270 & 1 & 57 \\
\hline Connecticut & 248 & - & 241 & 9 & 60 & $\mathrm{~N}$ & 15 \\
\hline Maine & 40 & 1 & 137 & 6 & 19 & - & 8 \\
\hline Massachusetts & 474 & 2 & 531 & 27 & 144 & 1 & 21 \\
\hline New Hampshire & 29 & - & 98 & 4 & 12 & $\mathrm{~N}$ & 2 \\
\hline Rhode Island & 82 & - & 73 & 4 & 28 & - & 10 \\
\hline Vermont & 14 & - & 56 & 1 & 7 & - & 1 \\
\hline Mid. Atlantic & 5,315 & 16 & 2,009 & 116 & 1,173 & 1 & 136 \\
\hline New Jersey & 1,029 & 6 & 519 & 34 & 199 & - & 17 \\
\hline New York (upstate) & 910 & 1 & 842 & 48 & 422 & - & 36 \\
\hline New York City & 2,282 & 6 & 648 & 34 & 228 & 1 & 37 \\
\hline Pennsylvania & 1,094 & 3 & $\mathrm{~N}$ & $\mathrm{~N}$ & 324 & - & 46 \\
\hline E.N. Central & 3,449 & 10 & 2,600 & 128 & 1,108 & 4 & 100 \\
\hline Illinois & 1,171 & 3 & $\mathrm{~N}$ & - & 249 & - & 30 \\
\hline Indiana & 431 & - & 624 & 32 & 129 & 1 & 8 \\
\hline Michigan & 703 & 2 & 614 & 34 & 229 & 1 & 20 \\
\hline Ohio & 932 & 2 & 936 & 45 & 406 & 2 & 30 \\
\hline Wisconsin & 212 & 3 & 426 & 17 & 95 & - & 12 \\
\hline W.N. Central & 1,053 & 10 & 954 & 83 & 254 & 1 & 46 \\
\hline lowa & 98 & 1 & $\mathrm{~N}$ & $\mathrm{~N}$ & 33 & - & 7 \\
\hline Kansas & 112 & 3 & 136 & $\mathrm{~N}$ & 19 & $\mathrm{~N}$ & 6 \\
\hline Minnesota & 245 & 5 & 487 & 41 & 59 & - & 17 \\
\hline Missouri & 468 & - & $\mathrm{N}$ & 23 & 106 & 1 & 11 \\
\hline Nebraska & 81 & 1 & 153 & 14 & 23 & - & 4 \\
\hline North Dakota & 24 & - & 88 & 5 & 4 & $\mathrm{~N}$ & 1 \\
\hline South Dakota & 25 & - & 90 & $\mathrm{~N}$ & 10 & $\mathrm{~N}$ & - \\
\hline S. Atlantic & 10,895 & 26 & 2,944 & 241 & 959 & - & 153 \\
\hline Delaware & 105 & - & 41 & 1 & 20 & - & 1 \\
\hline District of Columbia & 242 & - & 71 & 2 & 13 & - & 1 \\
\hline Florida & 5,257 & 6 & 792 & 89 & 280 & - & 49 \\
\hline Georgia & 1,401 & 1 & 925 & 62 & 93 & - & 15 \\
\hline Maryland & 778 & 1 & 428 & 34 & 144 & - & 13 \\
\hline North Carolina & 1,378 & 8 & $\mathrm{~N}$ & $\mathrm{~N}$ & 187 & - & 30 \\
\hline South Carolina & 741 & 2 & 421 & 23 & 45 & - & 10 \\
\hline Virginia & 912 & 6 & 19 & 19 & 129 & - & 25 \\
\hline West Virginia & 81 & 2 & 247 & 11 & 48 & - & 9 \\
\hline E.S. Central & 1,944 & 9 & 1,430 & 101 & 352 & 1 & 34 \\
\hline Alabama & 517 & - & 213 & 17 & 63 & 1 & 9 \\
\hline Kentucky & 235 & 1 & 189 & 12 & 95 & $\mathrm{~N}$ & 3 \\
\hline Mississippi & 463 & 1 & 261 & 23 & 33 & $\mathrm{~N}$ & 6 \\
\hline Tennessee & 729 & 7 & 767 & 49 & 161 & $\mathrm{~N}$ & 16 \\
\hline w.S. Central & 5,649 & 34 & 2,205 & 208 & 394 & - & 34 \\
\hline Arkansas & 283 & 2 & 290 & 26 & 38 & $\mathrm{~N}$ & 4 \\
\hline Louisiana & 1,400 & 6 & 353 & 27 & 64 & - & 9 \\
\hline Oklahoma & 276 & 2 & $\mathrm{~N}$ & 26 & 36 & - & 2 \\
\hline Texas & 3,690 & 24 & 1,562 & 129 & 256 & $\mathrm{~N}$ & 19 \\
\hline Mountain & 1,651 & 10 & 1,902 & 116 & 208 & 2 & 50 \\
\hline Arizona & 705 & 3 & 724 & 38 & 59 & 1 & 14 \\
\hline Colorado & 361 & 1 & 471 & 21 & 65 & $\mathrm{~N}$ & 10 \\
\hline Idaho & 12 & - & $\mathrm{N}$ & 7 & 17 & - & 3 \\
\hline Montana & 15 & - & 40 & 2 & 4 & - & 1 \\
\hline Nevada & 388 & 3 & 139 & 6 & 25 & - & 4 \\
\hline New Mexico & 124 & 1 & 299 & 14 & 8 & - & 9 \\
\hline Utah & 37 & 2 & 204 & 25 & 28 & 1 & 9 \\
\hline Wyoming & 9 & - & 25 & 3 & 2 & - & - \\
\hline Pacific & 4,763 & 23 & 176 & 21 & 448 & 28 & 159 \\
\hline Alaska & 41 & - & 87 & 10 & 2 & - & - \\
\hline California & 3,988 & 22 & $\mathrm{~N}$ & $\mathrm{~N}$ & 351 & 5 & 114 \\
\hline Hawaii & 82 & - & 89 & 11 & 7 & 23 & 5 \\
\hline Oregon & 215 & 1 & $\mathrm{~N}$ & $\mathrm{~N}$ & 33 & - & 16 \\
\hline Washington & 437 & - & $\mathrm{N}$ & $\mathrm{N}$ & 55 & - & 24 \\
\hline
\end{tabular}

See table footnotes on next page. 
TABLE 2g. (Continued) Number of reported cases of notifiable diseases, ${ }^{*}$ by region and reporting area — United States and U.S. territories, 2014

\begin{tabular}{|c|c|c|c|c|c|c|c|}
\hline \multirow[b]{2}{*}{ Area } & \multirow{2}{*}{$\begin{array}{c}\text { HIV } \\
\text { diagnoses }\end{array}$} & \multirow{2}{*}{$\begin{array}{l}\text { Influenza-associated } \\
\text { pediatric mortality }\end{array}$} & \multicolumn{2}{|c|}{ Invasive pneumococcal disease ${ }^{\S}$} & \multirow[b]{2}{*}{ Legionellosis } & \multirow[b]{2}{*}{ Leptospirosis } & \multirow[b]{2}{*}{ Listeriosis } \\
\hline & & & All ages & Age $<5$ years & & & \\
\hline \multicolumn{8}{|l|}{ Territories } \\
\hline American Samoa & - & - & $\mathrm{N}$ & - & $\mathrm{N}$ & - & $\mathrm{N}$ \\
\hline C.N.M.I. & - & - & - & - & - & - & - \\
\hline Guam & - & - & - & - & - & - & - \\
\hline Puerto Rico & 489 & - & - & - & 13 & 69 & - \\
\hline U.S. Virgin Islands & 16 & - & - & - & - & - & - \\
\hline
\end{tabular}

* No cases of anthrax; dengue hemorrhagic fever; eastern equine encephalitis, nonneuroinvasive; poliomyelitis, paralytic; poliovirus infection, nonparalytic; severe acute respiratory syndrome-associated coronavirus disease (SARS-CoV); smallpox; Vancomycin-resistant Staphylococcus aureus (VRSA); western equine encephalitis virus disease, neuroinvasive and nonneuroinvasive; and yellow fever were reported in the United States during 2014.

† Totals reported to the Influenza Division, National Center for Immunization and Respiratory Diseases (NCIRD), as of June 30, 2015.

$\S$ Streptococcus pneumoniae, invasive disease. Since January 1, 2010, "Invasive pneumococcal disease (IPD)" has been nationally notifiable and separate notifications for "Drug resistant S. pneumoniae" and "IPD in children $<5$ years of age" have been discontinued. 
TABLE $2 \mathrm{~h}$. Number of reported cases of notifiable diseases, ${ }^{*}$ by region and reporting area — United States and U.S. territories, 2014

\begin{tabular}{|c|c|c|c|c|c|c|c|}
\hline \multirow[b]{2}{*}{ Area } & \multicolumn{3}{|c|}{ Lyme disease } & \multirow[b]{2}{*}{ Malaria } & \multicolumn{3}{|c|}{ Measles } \\
\hline & Total & Confirmed & Probable & & Total & Indigenous & Imported \\
\hline United States & 33,461 & 25,359 & 8,102 & 1,653 & 667 & 604 & 63 \\
\hline New England & 11,292 & 8,168 & 3,124 & 120 & 13 & 6 & 7 \\
\hline Connecticut & 2,360 & 1,719 & 641 & 15 & 5 & 4 & 1 \\
\hline Maine & 1,401 & 1,169 & 232 & 7 & - & - & - \\
\hline Massachusetts & 5,304 & 3,646 & 1,658 & 61 & 8 & 2 & 6 \\
\hline New Hampshire & 724 & 622 & 102 & 11 & - & - & - \\
\hline Rhode Island & 904 & 570 & 334 & 22 & - & - & - \\
\hline Vermont & 599 & 442 & 157 & 4 & - & - & - \\
\hline Mid. Atlantic & 14,509 & 11,912 & 2,597 & 427 & 38 & 30 & 8 \\
\hline New Jersey & 3,286 & 2,589 & 697 & 79 & 3 & 1 & 2 \\
\hline New York (upstate) & 2,887 & 2,285 & 602 & 59 & 5 & 2 & 3 \\
\hline New York City & 849 & 568 & 281 & 204 & 27 & 25 & 2 \\
\hline Pennsylvania & 7,487 & 6,470 & 1,017 & 85 & 3 & 2 & 1 \\
\hline E.N. Central & 1,950 & 1,511 & 439 & 141 & 392 & 384 & 8 \\
\hline Illinois & 233 & 233 & - & 55 & 2 & 1 & 1 \\
\hline Indiana & 110 & 100 & 10 & 20 & 1 & - & 1 \\
\hline Michigan & 127 & 93 & 34 & 17 & 5 & 3 & 2 \\
\hline Ohio & 119 & 94 & 25 & 38 & 382 & 379 & 3 \\
\hline Wisconsin & 1,361 & 991 & 370 & 11 & 2 & 1 & 1 \\
\hline W.N. Central & 1,663 & 1,035 & 628 & 115 & 52 & 48 & 4 \\
\hline lowa & 194 & 110 & 84 & 17 & - & - & - \\
\hline Kansas & 20 & 12 & 8 & 9 & 14 & 13 & 1 \\
\hline Minnesota & 1,416 & 896 & 520 & 51 & 2 & 1 & 1 \\
\hline Missouri & 10 & 7 & 3 & 15 & 27 & 25 & 2 \\
\hline Nebraska & 7 & 6 & 1 & 9 & 1 & 1 & - \\
\hline North Dakota & 14 & 2 & 12 & 9 & - & - & - \\
\hline South Dakota & 2 & 2 & - & 5 & 8 & 8 & - \\
\hline S. Atlantic & 3,678 & 2,557 & 1,121 & 421 & 3 & 1 & 2 \\
\hline Delaware & 417 & 341 & 76 & 2 & - & - & - \\
\hline District of Columbia & 40 & 35 & 5 & 18 & - & - & - \\
\hline Florida & 155 & 85 & 70 & 52 & - & - & - \\
\hline Georgia & 4 & 4 & - & 82 & - & - & - \\
\hline Maryland & 1,373 & 957 & 416 & 146 & - & - & - \\
\hline North Carolina & 170 & 27 & 143 & 36 & 1 & - & 1 \\
\hline South Carolina & 37 & 20 & 17 & 6 & - & - & - \\
\hline Virginia & 1,346 & 976 & 370 & 77 & 2 & 1 & 1 \\
\hline West Virginia & 136 & 112 & 24 & 2 & - & - & - \\
\hline E.S. Central & 127 & 48 & 79 & 46 & 5 & 3 & 2 \\
\hline Alabama & 64 & 28 & 36 & 14 & 1 & - & 1 \\
\hline Kentucky & 44 & 11 & 33 & 11 & - & - & - \\
\hline Mississippi & 2 & 2 & - & 1 & - & - & - \\
\hline Tennessee & 17 & 7 & 10 & 20 & 4 & 3 & 1 \\
\hline W.S. Central & 42 & 20 & 22 & 143 & 10 & 7 & 3 \\
\hline Arkansas & - & - & - & 7 & - & - & - \\
\hline Louisiana & 2 & - & 2 & 20 & - & - & - \\
\hline Oklahoma & - & - & - & 10 & - & - & - \\
\hline Texas & 40 & 20 & 20 & 106 & 10 & 7 & 3 \\
\hline Mountain & 59 & 38 & 21 & 79 & 8 & 6 & 2 \\
\hline Arizona & 21 & 14 & 7 & 25 & 3 & 3 & - \\
\hline Colorado & - & - & - & 30 & 1 & - & 1 \\
\hline Idaho & 9 & 8 & 1 & 3 & - & - & - \\
\hline Montana & 7 & 5 & 2 & 2 & - & - & - \\
\hline Nevada & 6 & 4 & 2 & 11 & - & - & - \\
\hline New Mexico & - & - & - & 3 & 1 & 1 & - \\
\hline Utah & 13 & 5 & 8 & 5 & 3 & 2 & 1 \\
\hline Wyoming & 3 & 2 & 1 & - & - & - & - \\
\hline Pacific & 141 & 70 & 71 & 161 & 146 & 119 & 27 \\
\hline Alaska & 8 & 5 & 3 & 4 & - & - & - \\
\hline California & 73 & 54 & 19 & 95 & 92 & 75 & 17 \\
\hline Hawaii & $\mathrm{N}$ & $\mathrm{N}$ & $\mathrm{N}$ & 4 & 15 & 10 & 5 \\
\hline Oregon & 45 & 3 & 42 & 17 & 6 & 5 & 1 \\
\hline Washington & 15 & 8 & 7 & 41 & 33 & 29 & 4 \\
\hline
\end{tabular}

See table footnotes on next page. 
Morbidity and Mortality Weekly Report

TABLE 2h. (Continued) Number of reported cases of notifiable diseases, ${ }^{*}$ by region and reporting area — United States and U.S. territories, 2014

\begin{tabular}{|c|c|c|c|c|c|c|c|}
\hline \multirow[b]{2}{*}{ Area } & \multicolumn{3}{|c|}{ Lyme disease } & \multirow[b]{2}{*}{ Malaria } & \multicolumn{3}{|c|}{ Measles } \\
\hline & Total & Confirmed & Probable & & Total & Indigenous & Imported \\
\hline \multicolumn{8}{|l|}{ Territories } \\
\hline American Samoa & $\mathrm{N}$ & $\mathrm{N}$ & $\mathrm{N}$ & - & - & - & - \\
\hline C.N.M.I. & - & - & - & - & - & - & - \\
\hline Guam & - & - & - & - & 2 & 2 & - \\
\hline Puerto Rico & $\mathrm{N}$ & $\mathrm{N}$ & $\mathrm{N}$ & 1 & 2 & 2 & - \\
\hline U.S. Virgin Islands & $\mathrm{N}$ & $\mathrm{N}$ & $\mathrm{N}$ & - & - & - & - \\
\hline
\end{tabular}


TABLE 2i. Number of reported cases of notifiable diseases, ${ }^{*}$ by region and reporting area — United States and U.S. territories, 2014

\begin{tabular}{|c|c|c|c|c|c|c|c|c|}
\hline \multirow[b]{2}{*}{ Area } & \multicolumn{5}{|c|}{ Meningococcal disease } & \multirow{2}{*}{\multicolumn{2}{|c|}{$\begin{array}{c}\text { Novel } \\
\text { influenza A } \\
\text { virus } \\
\text { infections }\end{array}$}} & \multirow[b]{2}{*}{ Pertussis } \\
\hline & $\begin{array}{c}\text { All } \\
\text { Serogroups }\end{array}$ & $\begin{array}{c}\text { Serogroups } \\
\text { ACWY }\end{array}$ & Serogroup B & $\begin{array}{c}\text { Other } \\
\text { Serogroups }\end{array}$ & $\begin{array}{l}\text { Unknown } \\
\text { Serogroup }\end{array}$ & & & \\
\hline United States & 433 & 123 & 89 & 25 & 196 & 1,223 & 3 & 32,971 \\
\hline New England & 18 & 11 & 4 & 2 & 1 & 10 & - & 1,199 \\
\hline Connecticut & 3 & 3 & - & - & - & 3 & - & 100 \\
\hline Maine & 2 & 1 & - & 1 & - & - & - & 557 \\
\hline Massachusetts & 12 & 6 & 4 & 1 & 1 & 5 & - & 308 \\
\hline New Hampshire & - & - & - & - & - & 2 & - & 84 \\
\hline Rhode Island & 1 & 1 & - & - & - & - & - & 108 \\
\hline Vermont & - & - & - & - & - & - & - & 42 \\
\hline Mid. Atlantic & 51 & 7 & 11 & 3 & 30 & 193 & - & 2,223 \\
\hline New Jersey & 9 & - & - & - & 9 & 39 & - & 387 \\
\hline New York (upstate) & 8 & 2 & 5 & 1 & - & 12 & - & 901 \\
\hline New York City & 18 & - & - & - & 18 & 123 & - & 122 \\
\hline Pennsylvania & 16 & 5 & 6 & 2 & 3 & 19 & - & 813 \\
\hline E.N. Central & 50 & 19 & 21 & 3 & 7 & 805 & 3 & 5,658 \\
\hline Illinois & 12 & 7 & 4 & 1 & - & 142 & - & 764 \\
\hline Indiana & 4 & - & 4 & - & - & 25 & - & 492 \\
\hline Michigan & 12 & 4 & 5 & - & 3 & 20 & - & 1,424 \\
\hline Ohio & 12 & 7 & 2 & - & 3 & 552 & 2 & 1,463 \\
\hline Wisconsin & 10 & 1 & 6 & 2 & 1 & 66 & 1 & 1,515 \\
\hline W.N. Central & 22 & 3 & 3 & - & 16 & 41 & - & 2,689 \\
\hline lowa & 2 & 1 & 1 & - & - & 10 & - & 222 \\
\hline Kansas & 1 & 1 & - & - & - & 2 & - & 431 \\
\hline Minnesota & 7 & - & - & - & 7 & 22 & - & 950 \\
\hline Missouri & 8 & - & - & - & 8 & 6 & - & 558 \\
\hline Nebraska & - & - & - & - & - & - & - & 366 \\
\hline North Dakota & 2 & 1 & 1 & - & - & 1 & - & 52 \\
\hline South Dakota & 2 & - & 1 & - & 1 & - & - & 110 \\
\hline S. Atlantic & 102 & 17 & 22 & 5 & 58 & 47 & - & 3,002 \\
\hline Delaware & 1 & - & 1 & - & - & - & - & 205 \\
\hline District of Columbia & 1 & - & 1 & - & - & 16 & - & 22 \\
\hline Florida & 50 & - & - & - & 50 & 1 & - & 719 \\
\hline Georgia & 14 & 7 & 2 & 1 & 4 & 2 & - & 408 \\
\hline Maryland & 7 & 2 & 4 & 1 & - & 3 & - & 203 \\
\hline North Carolina & 13 & 6 & 5 & - & 2 & 2 & - & 752 \\
\hline South Carolina & 5 & - & 3 & 1 & 1 & 2 & - & 170 \\
\hline Virginia & 10 & 2 & 6 & 1 & 1 & 20 & - & 505 \\
\hline West Virginia & 1 & - & - & 1 & - & 1 & - & 18 \\
\hline E.S. Central & 19 & 9 & 3 & - & 7 & 8 & - & 983 \\
\hline Alabama & 7 & 4 & 1 & - & 2 & 2 & - & 285 \\
\hline Kentucky & 3 & - & - & - & 3 & 2 & - & 300 \\
\hline Mississippi & 1 & - & - & - & 1 & - & - & 68 \\
\hline Tennessee & 8 & 5 & 2 & - & 1 & 4 & - & 330 \\
\hline W.S. Central & 40 & 15 & 8 & 6 & 11 & 21 & - & 3,094 \\
\hline Arkansas & 1 & 1 & - & - & - & 1 & - & 286 \\
\hline Louisiana & 7 & - & - & - & 7 & 1 & - & 90 \\
\hline Oklahoma & 10 & 3 & 4 & 3 & - & 4 & - & 142 \\
\hline Texas & 22 & 11 & 4 & 3 & 4 & 15 & - & 2,576 \\
\hline Mountain & 33 & 17 & 6 & 4 & 6 & 49 & - & 4,176 \\
\hline Arizona & 9 & 4 & 4 & 1 & - & 12 & - & 517 \\
\hline Colorado & 9 & 5 & 1 & 2 & 1 & 4 & - & 1,282 \\
\hline Idaho & 5 & 2 & 1 & 1 & 1 & 26 & - & 367 \\
\hline Montana & 4 & 4 & - & - & - & 1 & - & 494 \\
\hline Nevada & 3 & - & - & - & 3 & 2 & - & 144 \\
\hline New Mexico & 2 & 2 & - & - & - & 2 & - & 370 \\
\hline Utah & 1 & - & - & - & 1 & 2 & - & 940 \\
\hline Wyoming & - & - & - & - & - & - & - & 62 \\
\hline Pacific & 98 & 25 & 11 & 2 & 60 & 49 & - & 9,947 \\
\hline Alaska & 3 & 3 & - & - & - & 1 & - & 169 \\
\hline California & 57 & - & - & - & 57 & 37 & - & 8,723 \\
\hline Hawaii & 2 & 1 & - & 1 & - & 1 & - & 38 \\
\hline Oregon & 19 & 11 & 5 & - & 3 & 1 & - & 416 \\
\hline Washington & 17 & 10 & 6 & 1 & - & 9 & - & 601 \\
\hline
\end{tabular}

See table footnotes on next page. 
TABLE 2i. (Continued) Number of reported cases of notifiable diseases, ${ }^{*}$ by region and reporting area — United States and U.S. territories, 2014

\begin{tabular}{|c|c|c|c|c|c|c|c|c|}
\hline \multirow[b]{2}{*}{ Area } & \multicolumn{5}{|c|}{ Meningococcal disease } & \multirow{2}{*}{\multicolumn{2}{|c|}{$\begin{array}{c}\text { Novel } \\
\text { influenza A } \\
\text { virus } \\
\text { infections }\end{array}$}} & \multirow[b]{2}{*}{ Pertussis } \\
\hline & $\begin{array}{c}\text { All } \\
\text { Serogroups }\end{array}$ & $\begin{array}{c}\text { Serogroups } \\
\text { ACWY }\end{array}$ & Serogroup B & $\begin{array}{l}\text { Other } \\
\text { Serogroups }\end{array}$ & $\begin{array}{l}\text { Unknown } \\
\text { Serogroup }\end{array}$ & & & \\
\hline \multicolumn{9}{|l|}{ Territories } \\
\hline American Samoa & - & - & - & - & - & - & - & - \\
\hline C.N.M.I. & - & - & - & - & - & - & - & - \\
\hline Guam & - & - & - & - & - & - & - & - \\
\hline Puerto Rico & - & - & - & - & - & - & - & 17 \\
\hline U.S. Virgin Islands & - & - & - & - & - & - & - & - \\
\hline
\end{tabular}


TABLE 2j. Number of reported cases of notifiable diseases,* by region and reporting area — United States and U.S. territories, 2014

\begin{tabular}{|c|c|c|c|c|c|c|c|c|}
\hline \multirow[b]{2}{*}{ Area } & \multirow[b]{2}{*}{ Plague } & \multirow[b]{2}{*}{ Psittacosis } & \multicolumn{3}{|c|}{ Q fever } & \multicolumn{2}{|c|}{ Rabies } & \multirow[b]{2}{*}{ Rubella } \\
\hline & & & Total & Acute & Chronic & Animal $^{\dagger}$ & Human & \\
\hline United States & 10 & 8 & 168 & 132 & 36 & 5,988 & 1 & 6 \\
\hline New England & - & - & 1 & - & 1 & 479 & - & - \\
\hline Connecticut & - & $\mathrm{N}$ & - & - & - & 183 & - & - \\
\hline Maine & - & - & - & - & - & 43 & - & - \\
\hline Massachusetts & - & - & 1 & - & 1 & 148 & - & - \\
\hline New Hampshire & - & - & $\mathrm{N}$ & $\mathrm{N}$ & $\mathrm{N}$ & 23 & - & - \\
\hline Rhode Island & - & - & - & - & - & 27 & - & - \\
\hline Vermont & - & - & $\mathrm{N}$ & - & - & 55 & - & - \\
\hline Mid. Atlantic & - & 1 & 18 & 13 & 5 & 1,136 & - & 1 \\
\hline New Jersey & - & 1 & 4 & 3 & 1 & 349 & - & - \\
\hline New York (upstate) & - & - & 6 & 6 & - & 372 & - & - \\
\hline New York City & - & - & 2 & - & 2 & 12 & - & - \\
\hline Pennsylvania & - & - & 6 & 4 & 2 & 403 & - & 1 \\
\hline E.N. Central & - & - & 18 & 8 & 10 & 150 & - & 1 \\
\hline Illinois & - & - & 4 & 2 & 2 & 40 & - & 1 \\
\hline Indiana & - & - & 2 & 2 & - & 12 & - & - \\
\hline Michigan & - & - & 2 & 1 & 1 & 43 & - & - \\
\hline Ohio & - & - & 4 & - & 4 & 28 & - & - \\
\hline Wisconsin & - & - & 6 & 3 & 3 & 27 & - & - \\
\hline W.N. Central & - & 5 & 15 & 14 & 1 & 204 & 1 & 1 \\
\hline lowa & - & - & $\mathrm{N}$ & $\mathrm{N}$ & $\mathrm{N}$ & 15 & - & - \\
\hline Kansas & - & - & 2 & 2 & - & 70 & - & - \\
\hline Minnesota & - & - & 3 & 3 & - & 33 & - & - \\
\hline Missouri & - & - & 1 & 1 & - & 26 & 1 & - \\
\hline Nebraska & - & 5 & 2 & 2 & - & 21 & - & 1 \\
\hline North Dakota & - & - & 2 & 2 & - & 18 & - & - \\
\hline South Dakota & - & - & 5 & 4 & 1 & 21 & - & - \\
\hline S. Atlantic & - & 1 & 11 & 10 & 1 & 1,833 & - & - \\
\hline Delaware & - & - & - & - & - & 9 & - & - \\
\hline District of Columbia & - & - & $\mathrm{N}$ & - & - & 40 & - & - \\
\hline Florida & - & 1 & 1 & 1 & - & 95 & - & - \\
\hline Georgia & - & - & - & - & - & 272 & - & - \\
\hline Maryland & - & - & - & - & - & 344 & - & - \\
\hline North Carolina & - & - & 3 & 3 & - & 355 & - & - \\
\hline South Carolina & - & - & - & - & - & 140 & - & - \\
\hline Virginia & - & - & 4 & 3 & 1 & 528 & - & - \\
\hline West Virginia & - & - & 3 & 3 & - & 50 & - & - \\
\hline E.S. Central & - & - & 4 & 4 & - & 137 & - & - \\
\hline Alabama & - & - & 2 & 2 & - & 86 & - & - \\
\hline Kentucky & - & - & - & - & - & 10 & - & - \\
\hline Mississippi & - & - & - & - & - & 1 & - & - \\
\hline Tennessee & - & - & 2 & 2 & - & 40 & - & - \\
\hline W.S. Central & - & - & 22 & 14 & 8 & 1,396 & - & - \\
\hline Arkansas & - & - & 5 & 5 & $\mathrm{~N}$ & 152 & - & - \\
\hline Louisiana & - & - & 1 & 1 & - & 5 & - & - \\
\hline Oklahoma & - & - & 4 & 2 & 2 & 106 & - & - \\
\hline Texas & - & $\mathrm{N}$ & 12 & 6 & 6 & 1,133 & - & - \\
\hline Mountain & 10 & - & 34 & 24 & 10 & 422 & - & 1 \\
\hline Arizona & - & - & 9 & 6 & 3 & 157 & - & - \\
\hline Colorado & 8 & - & 6 & 4 & 2 & 131 & - & - \\
\hline Idaho & - & - & 4 & 4 & - & 12 & - & - \\
\hline Montana & - & - & 4 & 2 & 2 & 16 & - & - \\
\hline Nevada & - & - & - & - & - & 14 & - & - \\
\hline New Mexico & 2 & - & 2 & 2 & - & 12 & - & - \\
\hline Utah & - & - & 9 & 6 & 3 & 22 & - & 1 \\
\hline Wyoming & - & - & - & - & - & 58 & - & - \\
\hline Pacific & - & 1 & 45 & 45 & - & 231 & - & 2 \\
\hline Alaska & - & - & - & - & - & 3 & - & - \\
\hline California & - & - & 35 & 35 & - & 200 & - & 2 \\
\hline Hawaii & - & - & - & - & - & U & - & - \\
\hline Oregon & - & - & 9 & 9 & - & 13 & - & - \\
\hline Washington & - & 1 & 1 & 1 & - & 15 & - & - \\
\hline
\end{tabular}

See table footnotes on next page. 
Morbidity and Mortality Weekly Report

TABLE 2j. (Continued) Number of reported cases of notifiable diseases, * by region and reporting area - United States and U.S. territories, 2014

\begin{tabular}{|c|c|c|c|c|c|c|c|c|}
\hline \multirow[b]{2}{*}{ Area } & \multirow[b]{2}{*}{ Plague } & \multirow[b]{2}{*}{ Psittacosis } & \multicolumn{3}{|c|}{$Q$ fever } & \multicolumn{2}{|c|}{ Rabies } & \multirow[b]{2}{*}{ Rubella } \\
\hline & & & Total & Acute & Chronic & Animal $^{\dagger}$ & Human & \\
\hline \multicolumn{9}{|l|}{ Territories } \\
\hline American Samoa & - & $\mathrm{N}$ & $\mathrm{N}$ & $\mathrm{N}$ & $\mathrm{N}$ & U & U & - \\
\hline C.N.M.I. & - & - & - & - & - & - & - & - \\
\hline Guam & - & - & $\mathrm{N}$ & $\mathrm{N}$ & $\mathrm{N}$ & - & - & - \\
\hline Puerto Rico & - & $\mathrm{N}$ & - & - & - & 45 & - & - \\
\hline U.S. Virgin Islands & - & - & - & - & - & - & - & - \\
\hline
\end{tabular}

* No cases of anthrax; dengue hemorrhagic fever; eastern equine encephalitis, nonneuroinvasive; poliomyelitis, paralytic; poliovirus infection, nonparalytic; severe acute respiratory syndromeassociated coronavirus disease (SARS-CoV); smallpox; Vancomycin-resistant Staphylococcus aureus (VRSA); western equine encephalitis virus disease, neuroinvasive and nonneuroinvasive; and yellow fever were reported in the United States during 2014.

† Totals reported to the National Center for Emerging and Zoonotic Infectious Diseases, Division of High-consequence Pathogens and Pathology, as of December 14, 2015. 


\begin{tabular}{|c|c|c|c|c|c|c|c|c|}
\hline \multirow[b]{2}{*}{ Area } & \multirow{2}{*}{$\begin{array}{l}\text { Rubella, } \\
\text { Congenital } \\
\text { syndrome }\end{array}$} & \multirow[b]{2}{*}{ Salmonellosis } & \multirow{2}{*}{$\begin{array}{l}\text { Shiga toxin- } \\
\text { producing } \\
\text { Escherichia coli } \\
\text { (STEC) }^{\dagger}\end{array}$} & \multirow[b]{2}{*}{ Shigellosis } & \multicolumn{3}{|c|}{ Spotted Fever Rickettsiosis ${ }^{\S}$} & \multirow{2}{*}{$\begin{array}{c}\text { Streptococca } \\
\text { toxic shock } \\
\text { syndrome }\end{array}$} \\
\hline & & & & & Total & Confirmed & Probable & \\
\hline United States & 1 & 51,455 & 6,179 & 20,745 & 3,757 & 115 & 3,634 & 259 \\
\hline New England & - & 2,231 & 223 & 335 & 19 & 1 & 18 & 46 \\
\hline Connecticut & - & 457 & 60 & 67 & 6 & - & 6 & 19 \\
\hline Maine & - & 127 & 33 & 29 & 3 & - & 3 & 18 \\
\hline Massachusetts & - & 1,223 & 95 & 187 & 8 & - & 8 & 6 \\
\hline New Hampshire & - & 191 & 16 & 14 & 2 & 1 & 1 & - \\
\hline Rhode Island & - & 140 & 4 & 34 & - & - & - & 1 \\
\hline Vermont & - & 93 & 15 & 4 & - & - & - & 2 \\
\hline Mid. Atlantic & - & 4,968 & 577 & 1,224 & 86 & 2 & 84 & 50 \\
\hline New Jersey & - & 1,170 & 124 & 297 & 58 & - & 58 & 37 \\
\hline New York (upstate) & - & 1,320 & 200 & 281 & 20 & 1 & 19 & 13 \\
\hline New York City & - & 1,008 & 70 & 443 & 1 & - & 1 & - \\
\hline Pennsylvania & - & 1,470 & 183 & 203 & 7 & 1 & 6 & - \\
\hline E.N. Central & 1 & 5,672 & 871 & 3,475 & 148 & 2 & 146 & 78 \\
\hline Illinois & 1 & 1,778 & 195 & 840 & 89 & 1 & 88 & 52 \\
\hline Indiana & - & 725 & 117 & 1,362 & 36 & - & 36 & 12 \\
\hline Michigan & - & 1,053 & 133 & 310 & - & - & - & 4 \\
\hline Ohio & - & 1,199 & 204 & 606 & 12 & - & 12 & 9 \\
\hline Wisconsin & - & 917 & 222 & 357 & 11 & 1 & 10 & 1 \\
\hline W.N. Central & - & 3,038 & 1,013 & 2,615 & 411 & 8 & 403 & 11 \\
\hline lowa & - & 527 & 224 & 208 & 10 & - & 10 & - \\
\hline Kansas & - & 428 & 90 & 55 & 110 & - & 110 & 2 \\
\hline Minnesota & - & 727 & 332 & 95 & 7 & - & 7 & 8 \\
\hline Missouri & - & 839 & 180 & 1,395 & 265 & 2 & 263 & 1 \\
\hline Nebraska & - & 259 & 107 & 220 & 13 & 3 & 10 & - \\
\hline North Dakota & - & 88 & 39 & 21 & 3 & 2 & 1 & - \\
\hline South Dakota & - & 170 & 41 & 621 & 3 & 1 & 2 & - \\
\hline S. Atlantic & - & 14,163 & 514 & 4,768 & 1,002 & 56 & 946 & 35 \\
\hline Delaware & - & 157 & 14 & 74 & 24 & - & 24 & - \\
\hline District of Columbia & - & 64 & 5 & 118 & - & - & - & - \\
\hline Florida & - & 6,019 & 117 & 2,396 & 29 & 2 & 27 & $\mathrm{~N}$ \\
\hline Georgia & - & 2,242 & 97 & 1,021 & 37 & 37 & - & - \\
\hline Maryland & - & 894 & 74 & 260 & 6 & 2 & 4 & 4 \\
\hline North Carolina & - & 2,057 & 51 & 510 & 496 & 10 & 486 & 20 \\
\hline South Carolina & - & 1,399 & 15 & 162 & 32 & 1 & 31 & 1 \\
\hline Virginia & - & 1,151 & 121 & 214 & 373 & 4 & 369 & 10 \\
\hline West Virginia & - & 180 & 20 & 13 & 5 & - & 5 & - \\
\hline E.S. Central & - & 3,738 & 323 & 1,893 & 881 & 25 & 850 & 4 \\
\hline Alabama & - & 1,165 & 41 & 516 & 220 & 8 & 206 & - \\
\hline Kentucky & - & 585 & 97 & 344 & 53 & - & 53 & 4 \\
\hline Mississippi & - & 990 & 31 & 199 & 50 & 4 & 46 & $\mathrm{~N}$ \\
\hline Tennessee & - & 998 & 154 & 834 & 558 & 13 & 545 & - \\
\hline W.S. Central & - & 7,821 & 843 & 3,791 & 1,155 & 3 & 1,152 & 2 \\
\hline Arkansas & - & 668 & 89 & 770 & 824 & - & 824 & - \\
\hline Louisiana & - & 1,210 & 18 & 139 & 18 & - & 18 & 2 \\
\hline Oklahoma & - & 798 & 124 & 139 & 219 & 3 & 216 & $\mathrm{~N}$ \\
\hline Texas & - & 5,145 & 612 & 2,743 & 94 & - & 94 & $\mathrm{~N}$ \\
\hline Mountain & - & 2,933 & 627 & 749 & 37 & 10 & 25 & 33 \\
\hline Arizona & - & 1,046 & 98 & 376 & 16 & 6 & 10 & 4 \\
\hline Colorado & - & 616 & 168 & 80 & 5 & 1 & 4 & 2 \\
\hline Idaho & - & 174 & 116 & 12 & 1 & - & 1 & 1 \\
\hline Montana & - & 146 & 39 & 44 & 4 & 1 & 3 & - \\
\hline Nevada & - & 173 & 36 & 36 & 1 & - & 1 & 12 \\
\hline New Mexico & - & 333 & 47 & 64 & 2 & 1 & 1 & - \\
\hline Utah & - & 370 & 91 & 41 & 8 & 1 & 5 & 13 \\
\hline Wyoming & - & 75 & 32 & 96 & - & - & - & 1 \\
\hline Pacific & - & 6,891 & 1,188 & 1,895 & 18 & 8 & 10 & - \\
\hline Alaska & - & 68 & - & 4 & $\mathrm{~N}$ & $\mathrm{~N}$ & $\mathrm{~N}$ & $\mathrm{~N}$ \\
\hline California & - & 5,358 & 691 & 1,655 & 11 & 5 & 6 & $\mathrm{~N}$ \\
\hline Hawaii & - & 323 & 25 & 29 & $\mathrm{~N}$ & $\mathrm{~N}$ & $\mathrm{~N}$ & - \\
\hline Oregon & - & 401 & 185 & 50 & 5 & 2 & 3 & $\mathrm{~N}$ \\
\hline Washington & - & 741 & 287 & 157 & 2 & 1 & 1 & $\mathrm{~N}$ \\
\hline
\end{tabular}

See table footnotes on next page. 
TABLE 2k. (Continued) Number of reported cases of notifiable diseases, ${ }^{*}$ by region and reporting area — United States and U.S. territories, 2014

\begin{tabular}{|c|c|c|c|c|c|c|c|c|}
\hline \multirow[b]{2}{*}{ Area } & \multirow{2}{*}{$\begin{array}{l}\text { Rubella, } \\
\text { Congenital } \\
\text { syndrome }\end{array}$} & \multirow[b]{2}{*}{ Salmonellosis } & \multirow{2}{*}{$\begin{array}{l}\text { Shiga toxin- } \\
\text { producing } \\
\text { Escherichia coli } \\
\text { (STEC) }^{\dagger}\end{array}$} & \multirow[b]{2}{*}{ Shigellosis } & \multicolumn{3}{|c|}{ Spotted Fever Rickettsiosis ${ }^{\S}$} & \multirow{2}{*}{$\begin{array}{l}\text { Streptococcal } \\
\text { toxic shock } \\
\text { syndrome }\end{array}$} \\
\hline & & & & & Total & Confirmed & Probable & \\
\hline \multicolumn{9}{|l|}{ Territories } \\
\hline American Samoa & - & - & - & - & $\mathrm{N}$ & $\mathrm{N}$ & $\mathrm{N}$ & $\mathrm{N}$ \\
\hline C.N.M.I. & - & - & - & - & - & - & - & - \\
\hline Guam & - & 13 & - & 4 & $\mathrm{~N}$ & $\mathrm{~N}$ & $\mathrm{~N}$ & - \\
\hline Puerto Rico & $\mathrm{N}$ & 832 & 5 & 26 & $\mathrm{~N}$ & $\mathrm{~N}$ & $\mathrm{~N}$ & $\mathrm{~N}$ \\
\hline U.S. Virgin Islands & - & - & - & - & $\mathrm{N}$ & $\mathrm{N}$ & $\mathrm{N}$ & - \\
\hline
\end{tabular}

* No cases of anthrax; dengue hemorrhagic fever; eastern equine encephalitis, nonneuroinvasive; poliomyelitis, paralytic; poliovirus infection, nonparalytic; severe acute respiratory syndrome-associated coronavirus disease (SARS-CoV); smallpox; Vancomycin-resistant Staphylococcus aureus (VRSA); western equine encephalitis virus disease, neuroinvasive and nonneuroinvasive; and yellow fever were reported in the United States during 2014.

† Includes E. coli O157:H7; shiga toxin-positive, serogroup non-O157; and shiga toxin positive, not serogrouped.

$\S$ Total case count includes eight unknown case status reports. 
TABLE 2I. Number of reported cases of notifiable diseases, ${ }^{*}$ by region and reporting area — United States and U.S. territories, 2014

\begin{tabular}{|c|c|c|c|c|c|c|}
\hline \multirow[b]{2}{*}{ Area } & \multicolumn{3}{|c|}{ Syphilis ${ }^{\dagger, \S}$} & \multirow[b]{2}{*}{ Tetanus } & \multirow[b]{2}{*}{$\begin{array}{l}\text { Toxic shock } \\
\text { syndrome }\end{array}$} & \multirow[b]{2}{*}{ Trichinellosis } \\
\hline & All Stages & $\begin{array}{l}\text { Primary and } \\
\text { Secondary }\end{array}$ & Congenital & & & \\
\hline United States & 63,450 & 19,999 & 458 & 25 & 59 & 13 \\
\hline New England & 1,256 & 515 & 3 & - & 2 & - \\
\hline Connecticut & 169 & 86 & - & - & $\mathrm{N}$ & - \\
\hline Maine & 23 & 16 & - & - & - & - \\
\hline Massachusetts & 813 & 301 & 3 & - & - & - \\
\hline New Hampshire & 79 & 36 & - & - & - & - \\
\hline Rhode Island & 160 & 71 & - & - & 1 & - \\
\hline Vermont & 12 & 5 & - & - & 1 & - \\
\hline Mid. Atlantic & 9,825 & 2,556 & 27 & 2 & 7 & - \\
\hline New Jersey & 1,172 & 297 & - & - & 2 & - \\
\hline New York (upstate) & 1,341 & 401 & 3 & - & 4 & - \\
\hline New York City & 5,788 & 1,326 & 19 & - & - & - \\
\hline Pennsylvania & 1,524 & 532 & 5 & 2 & 1 & - \\
\hline E.N. Central & 5,880 & 2,106 & 65 & 3 & 17 & 2 \\
\hline Illinois & 2,796 & 863 & 27 & - & 2 & - \\
\hline Indiana & 475 & 168 & 8 & 1 & - & 1 \\
\hline Michigan & 1,095 & 421 & 15 & - & 4 & - \\
\hline Ohio & 1,229 & 568 & 15 & 1 & 9 & 1 \\
\hline Wisconsin & 285 & 86 & - & 1 & 2 & - \\
\hline W.N. Central & 2,083 & 857 & 6 & 2 & 6 & - \\
\hline lowa & 239 & 72 & 1 & - & 1 & - \\
\hline Kansas & 200 & 60 & - & - & - & - \\
\hline Minnesota & 631 & 257 & - & 2 & 5 & - \\
\hline Missouri & 771 & 352 & 1 & - & - & - \\
\hline Nebraska & 96 & 50 & 1 & - & - & - \\
\hline North Dakota & 51 & 13 & - & - & - & - \\
\hline South Dakota & 95 & 53 & 3 & - & - & - \\
\hline S. Atlantic & 14,857 & 4,886 & 93 & 3 & 9 & 1 \\
\hline Delaware & 110 & 47 & - & - & 1 & - \\
\hline District of Columbia & 281 & 116 & - & - & - & - \\
\hline Florida & 6,102 & 1,740 & 47 & 2 & $\mathrm{~N}$ & - \\
\hline Georgia & 3,384 & 1,234 & 17 & - & 4 & $\mathrm{~N}$ \\
\hline Maryland & 1,475 & 449 & 16 & 1 & $\mathrm{~N}$ & - \\
\hline North Carolina & 1,998 & 733 & 6 & - & 2 & - \\
\hline South Carolina & 750 & 250 & 5 & - & 1 & - \\
\hline Virginia & 702 & 289 & 2 & - & $\mathrm{N}$ & 1 \\
\hline West Virginia & 55 & 28 & - & - & 1 & - \\
\hline E.S. Central & 2,541 & 745 & 9 & 1 & 6 & - \\
\hline Alabama & 475 & 161 & 3 & - & - & - \\
\hline Kentucky & 447 & 158 & 3 & - & 1 & - \\
\hline Mississippi & 642 & 189 & 1 & 1 & $\mathrm{~N}$ & - \\
\hline Tennessee & 977 & 237 & 2 & - & 5 & - \\
\hline W.S. Central & 10,780 & 2,483 & 132 & 6 & 2 & 2 \\
\hline Arkansas & 389 & 121 & 6 & - & 2 & $\mathrm{~N}$ \\
\hline Louisiana & 2,173 & 575 & 46 & 1 & - & - \\
\hline Oklahoma & 414 & 151 & 6 & 1 & $\mathrm{~N}$ & - \\
\hline Texas & 7,804 & 1,636 & 74 & 4 & $\mathrm{~N}$ & 2 \\
\hline Mountain & 3,201 & 1,317 & 20 & - & 7 & 2 \\
\hline Arizona & 1,459 & 577 & 13 & - & 2 & - \\
\hline Colorado & 355 & 186 & - & - & 4 & 1 \\
\hline Idaho & 46 & 12 & - & - & - & - \\
\hline Montana & 9 & 8 & - & - & - & - \\
\hline Nevada & 894 & 357 & 6 & - & - & - \\
\hline New Mexico & 283 & 126 & 1 & - & - & - \\
\hline Utah & 149 & 47 & - & - & 1 & 1 \\
\hline Wyoming & 6 & 4 & - & - & - & - \\
\hline Pacific & 13,027 & 4,534 & 103 & 8 & 3 & 6 \\
\hline Alaska & 45 & 15 & - & 1 & $\mathrm{~N}$ & 2 \\
\hline California & 11,440 & 3,835 & 99 & 4 & 3 & 2 \\
\hline Hawaii & 106 & 68 & - & - & $\mathrm{N}$ & - \\
\hline Oregon & 582 & 272 & 2 & - & $\mathrm{N}$ & - \\
\hline Washington & 854 & 344 & 2 & 3 & $\mathrm{~N}$ & 2 \\
\hline
\end{tabular}

See table footnotes on next page. 
TABLE 2I. (Continued) Number of reported cases of notifiable diseases, ${ }^{*}$ by region and reporting area — United States and U.S. territories, 2014

\begin{tabular}{|c|c|c|c|c|c|c|}
\hline \multirow[b]{2}{*}{ Area } & \multicolumn{3}{|c|}{ Syphilis ${ }^{\dagger, \S}$} & \multirow[b]{2}{*}{ Tetanus } & \multirow[b]{2}{*}{$\begin{array}{l}\text { Toxic shock } \\
\text { syndrome }\end{array}$} & \multirow[b]{2}{*}{ Trichinellosis } \\
\hline & All Stages & $\begin{array}{l}\text { Primary and } \\
\text { Secondary }\end{array}$ & Congenital & & & \\
\hline \multicolumn{7}{|l|}{ Territories } \\
\hline American Samoa & - & - & - & - & $\mathrm{N}$ & $\mathrm{N}$ \\
\hline C.N.M.I. & - & - & - & - & - & - \\
\hline Guam & 13 & 7 & - & - & - & - \\
\hline Puerto Rico & 960 & 484 & - & - & $\mathrm{N}$ & $\mathrm{N}$ \\
\hline U.S. Virgin Islands & 6 & 2 & - & - & - & - \\
\hline
\end{tabular}

* No cases of anthrax; dengue hemorrhagic fever; eastern equine encephalitis, nonneuroinvasive; poliomyelitis, paralytic; poliovirus infection, nonparalytic; severe acute respiratory syndrome-associated coronavirus disease (SARS-CoV); smallpox; Vancomycin-resistant Staphylococcus aureus (VRSA); western equine encephalitis virus disease, neuroinvasive and nonneuroinvasive; and yellow fever were reported in the United States during 2014.

† Includes the following categories: primary, secondary, latent (including early latent, late latent, and latent syphilis of unknown duration), neurosyphilis, late (including late syphilis with clinical manifestations other than neurosyphilis), and congenital syphilis.

$\S$ Totals reported to the Division of STD Prevention, NCHHSTP, as of June 10, 2015. 
TABLE $2 \mathrm{~m}$. Number of reported cases of notifiable diseases, ${ }^{*}$ by region and reporting area — United States and U.S. territories, 2014

\begin{tabular}{|c|c|c|c|c|}
\hline Area & Tuberculosis $^{\dagger}$ & Tularemia & Typhoid fever & $\begin{array}{l}\text { Vancomycin-intermediate } \\
\text { Staphylococcus aureus (VISA) }\end{array}$ \\
\hline United States & 9,421 & 180 & 349 & 212 \\
\hline New England & 307 & 4 & 19 & 2 \\
\hline Connecticut & 60 & - & 1 & - \\
\hline Maine & 14 & - & - & 1 \\
\hline Massachusetts & 199 & 3 & 15 & - \\
\hline New Hampshire & 11 & - & 1 & $\mathrm{~N}$ \\
\hline Rhode Island & 21 & - & 2 & 1 \\
\hline Vermont & 2 & 1 & - & - \\
\hline Mid. Atlantic & 1,304 & 4 & 85 & 62 \\
\hline New Jersey & 308 & 1 & 21 & 7 \\
\hline New York (upstate) & 202 & 3 & 10 & 31 \\
\hline New York City & 585 & - & 39 & 20 \\
\hline Pennsylvania & 209 & - & 15 & 4 \\
\hline E.N. Central & 736 & 12 & 38 & 17 \\
\hline Illinois & 320 & 7 & 15 & 3 \\
\hline Indiana & 108 & 2 & 5 & - \\
\hline Michigan & 105 & 2 & 9 & 3 \\
\hline Ohio & 156 & 1 & 7 & 9 \\
\hline Wisconsin & 47 & - & 2 & 2 \\
\hline W.N. Central & 381 & 63 & 15 & 106 \\
\hline lowa & 54 & 1 & 1 & $\mathrm{~N}$ \\
\hline Kansas & 40 & 27 & 1 & - \\
\hline Minnesota & 147 & - & 6 & - \\
\hline Missouri & 79 & 20 & 5 & 104 \\
\hline Nebraska & 38 & 6 & - & - \\
\hline North Dakota & 15 & 4 & 2 & - \\
\hline South Dakota & 8 & 5 & - & 2 \\
\hline S. Atlantic & 1,667 & 2 & 56 & 16 \\
\hline Delaware & 22 & - & 4 & - \\
\hline District of Columbia & 32 & - & - & - \\
\hline Florida & 595 & 1 & 13 & 4 \\
\hline Georgia & 335 & - & 10 & 3 \\
\hline Maryland & 198 & - & 16 & 1 \\
\hline North Carolina & 195 & - & 4 & 4 \\
\hline South Carolina & 79 & - & - & 1 \\
\hline Virginia & 198 & - & 9 & 3 \\
\hline West Virginia & 13 & 1 & - & - \\
\hline E.S. Central & 438 & 3 & 4 & 3 \\
\hline Alabama & 133 & - & 2 & 2 \\
\hline Kentucky & 80 & 1 & - & - \\
\hline Mississippi & 74 & - & - & - \\
\hline Tennessee & 151 & 2 & 2 & 1 \\
\hline W.S. Central & 1,542 & 60 & 23 & 5 \\
\hline Arkansas & 93 & 42 & 1 & - \\
\hline Louisiana & 121 & 1 & - & - \\
\hline Oklahoma & 59 & 17 & 2 & - \\
\hline Texas & 1,269 & - & 20 & 5 \\
\hline Mountain & 431 & 24 & 21 & 1 \\
\hline Arizona & 193 & - & 4 & - \\
\hline Colorado & 64 & 16 & 6 & $\mathrm{~N}$ \\
\hline Idaho & 11 & - & - & $\mathrm{N}$ \\
\hline Montana & 6 & 1 & 3 & - \\
\hline Nevada & 74 & - & 3 & - \\
\hline New Mexico & 50 & 5 & 1 & $\mathrm{~N}$ \\
\hline Utah & 31 & 1 & 4 & 1 \\
\hline Wyoming & 2 & 1 & - & - \\
\hline Pacific & 2,615 & 8 & 88 & - \\
\hline Alaska & 62 & - & - & $\mathrm{N}$ \\
\hline California & 2,145 & - & 66 & $\mathrm{~N}$ \\
\hline Hawaii & 136 & - & 4 & - \\
\hline Oregon & 77 & 4 & 3 & $\mathrm{~N}$ \\
\hline Washington & 195 & 4 & 15 & $\mathrm{~N}$ \\
\hline
\end{tabular}

See table footnotes on next page. 
TABLE $2 \mathrm{~m}$. (Continued) Number of reported cases of notifiable diseases, ${ }^{*}$ by region and reporting area — United States and U.S. territories, 2014

Vancomycin-intermediate

\begin{tabular}{|c|c|c|c|c|}
\hline Area & Tuberculosis $^{\dagger}$ & Tularemia & Typhoid fever & Staphylococcus aureus (VISA) \\
\hline \multicolumn{5}{|l|}{ Territories } \\
\hline American Samoa & 1 & - & - & $\mathrm{N}$ \\
\hline C.N.M.I. & 23 & - & - & - \\
\hline Guam & 56 & - & - & - \\
\hline Puerto Rico & 44 & - & 1 & - \\
\hline U.S. Virgin Islands & - & - & - & - \\
\hline
\end{tabular}

* No cases of anthrax; dengue hemorrhagic fever; eastern equine encephalitis, nonneuroinvasive; poliomyelitis, paralytic; poliovirus infection, nonparalytic; severe acute respiratory syndrome-associated coronavirus disease (SARS-CoV); smallpox; Vancomycin-resistant Staphylococcus aureus (VRSA); western equine encephalitis virus disease, neuroinvasive and nonneuroinvasive; and yellow fever were reported in the United States during 2014.

${ }^{\dagger}$ Totals reported to the Division of Tuberculosis Elimination, NCHHSTP, as of July 1, 2015. 
TABLE 2 n. Number of reported cases of notifiable diseases, ${ }^{*}$ by region and reporting area — United States and U.S. territories, 2014

\begin{tabular}{|c|c|c|c|c|}
\hline \multirow[b]{2}{*}{ Area } & \multicolumn{2}{|c|}{ Varicella } & \multirow[b]{2}{*}{ Vibriosis } & \multirow[b]{2}{*}{ Viral hemorrhagic fever $§$} \\
\hline & Morbidity & Mortality $^{\dagger}$ & & \\
\hline United States & 10,172 & 4 & 1,261 & 5 \\
\hline New England & 1,147 & - & 86 & - \\
\hline Connecticut & 186 & - & 15 & - \\
\hline Maine & 207 & - & 9 & - \\
\hline Massachusetts & 470 & $\mathrm{~N}$ & 51 & - \\
\hline New Hampshire & 112 & - & 5 & - \\
\hline Rhode Island & 54 & - & 6 & - \\
\hline Vermont & 118 & - & - & - \\
\hline Mid. Atlantic & 1,151 & - & 70 & 1 \\
\hline New Jersey & 317 & - & 34 & - \\
\hline New York (upstate) & $\mathrm{N}$ & $\mathrm{N}$ & $\mathrm{N}$ & - \\
\hline New York City & - & - & 17 & 1 \\
\hline Pennsylvania & 834 & - & 19 & - \\
\hline E.N. Central & 2,498 & - & 63 & - \\
\hline Illinois & 596 & - & 24 & - \\
\hline Indiana & 220 & - & 6 & - \\
\hline Michigan & 728 & - & 7 & - \\
\hline Ohio & 535 & $\mathrm{~N}$ & 12 & - \\
\hline Wisconsin & 419 & - & 14 & - \\
\hline W.N. Central & 855 & - & 38 & 1 \\
\hline lowa & $\mathrm{N}$ & $\mathrm{N}$ & $\mathrm{N}$ & - \\
\hline Kansas & 294 & - & 2 & - \\
\hline Minnesota & 297 & - & 25 & 1 \\
\hline Missouri & 201 & - & 8 & - \\
\hline Nebraska & 19 & - & 2 & - \\
\hline North Dakota & 21 & - & 1 & - \\
\hline South Dakota & 23 & - & $\mathrm{N}$ & - \\
\hline S. Atlantic & 1,282 & 3 & 326 & - \\
\hline Delaware & 15 & - & 5 & - \\
\hline District of Columbia & - & - & 1 & - \\
\hline Florida & 570 & 1 & 166 & - \\
\hline Georgia & 64 & 1 & 18 & - \\
\hline Maryland & $\mathrm{N}$ & - & 42 & - \\
\hline North Carolina & $\mathrm{N}$ & $\mathrm{N}$ & 14 & - \\
\hline South Carolina & 151 & - & 18 & - \\
\hline Virginia & 324 & 1 & 59 & - \\
\hline West Virginia & 158 & $\mathrm{~N}$ & 3 & - \\
\hline E.S. Central & 111 & - & 55 & - \\
\hline Alabama & 107 & - & 20 & - \\
\hline Kentucky & $\mathrm{N}$ & $\mathrm{N}$ & 9 & - \\
\hline Mississippi & 4 & $\mathrm{~N}$ & 11 & - \\
\hline Tennessee & $\mathrm{N}$ & - & 15 & - \\
\hline W.S. Central & 1,943 & 1 & 130 & 3 \\
\hline Arkansas & 254 & $\mathrm{~N}$ & $\mathrm{~N}$ & - \\
\hline Louisiana & 42 & - & 50 & - \\
\hline Oklahoma & $\mathrm{N}$ & $\mathrm{N}$ & 2 & - \\
\hline Texas & 1,647 & 1 & 78 & 3 \\
\hline Mountain & 1,059 & - & 57 & - \\
\hline Arizona & 300 & - & 36 & - \\
\hline Colorado & 386 & $\mathrm{~N}$ & 13 & - \\
\hline Idaho & $\mathrm{N}$ & $\mathrm{N}$ & $\mathrm{N}$ & - \\
\hline Montana & 72 & - & 2 & - \\
\hline Nevada & $\mathrm{N}$ & $\mathrm{N}$ & 2 & - \\
\hline New Mexico & 75 & $\mathrm{~N}$ & 1 & - \\
\hline Utah & 215 & - & 2 & - \\
\hline Wyoming & 11 & $N$ & 1 & - \\
\hline Pacific & 126 & - & 436 & - \\
\hline Alaska & 31 & - & 5 & - \\
\hline California & 43 & - & 272 & - \\
\hline Hawaii & 52 & - & 38 & - \\
\hline Oregon & $\mathrm{N}$ & $\mathrm{N}$ & 29 & - \\
\hline Washington & $\mathrm{N}$ & - & 92 & - \\
\hline
\end{tabular}

See table footnotes on next page. 
TABLE 2n. (Continued) Number of reported cases of notifiable diseases, ${ }^{*}$ by region and reporting area - United States and U.S. territories, 2014

\begin{tabular}{|c|c|c|c|c|}
\hline \multirow[b]{2}{*}{ Area } & \multicolumn{2}{|c|}{ Varicella } & \multirow[b]{2}{*}{ Vibriosis } & \multirow[b]{2}{*}{ Viral hemorrhagic fever $\S$} \\
\hline & Morbidity & Mortality $^{\dagger}$ & & \\
\hline \multicolumn{5}{|l|}{ Territories } \\
\hline American Samoa & $\mathrm{N}$ & $\mathrm{N}$ & $\mathrm{N}$ & - \\
\hline C.N.M.I. & - & - & - & - \\
\hline Guam & 33 & $\mathrm{~N}$ & - & - \\
\hline Puerto Rico & 231 & - & - & - \\
\hline U.S. Virgin Islands & - & - & - & - \\
\hline
\end{tabular}

* No cases of anthrax; dengue hemorrhagic fever; eastern equine encephalitis, nonneuroinvasive; poliomyelitis, paralytic; poliovirus infection, nonparalytic; severe acute respiratory syndrome-associated coronavirus disease (SARS-CoV); smallpox; Vancomycin-resistant Staphylococcus aureus (VRSA); western equine encephalitis virus disease, neuroinvasive and nonneuroinvasive; and yellow fever were reported in the United States during 2014.

† Totals reported to the Division of Viral Diseases, National Center for Immunization and Respiratory Diseases (NCIRD), as of June 30, 2015.

$\S$ In addition to the four cases of Ebola Virus Disease diagnosed in the United States in 2014, six patients were medically evacuated to the United States for care after being diagnosed with Ebola Virus Disease in West Africa. In total, 11 VHF cases were reported for 2014, 10 confirmed infections with Ebola virus and one confirmed infection with Lassa virus. 
TABLE 3. Number of reported cases of notifiable diseases* and rates per 100,000 population, by age group, excluding U.S. territories United States, 2014

\begin{tabular}{|c|c|c|c|c|c|c|c|c|c|c|c|c|c|c|c|c|}
\hline \multirow[b]{2}{*}{ Disease } & \multicolumn{2}{|c|}{$<1 \mathrm{yr}$} & \multicolumn{2}{|c|}{$1-4$ yrs } & \multicolumn{2}{|c|}{$5-14$ yrs } & \multicolumn{2}{|c|}{$15-24$ yrs } & \multicolumn{2}{|c|}{$25-39$ yrs } & \multicolumn{2}{|c|}{$40-64$ yrs } & \multicolumn{2}{|c|}{$\geq 65$ yrs } & \multicolumn{2}{|c|}{ Age not stated } \\
\hline & No. & Rate & No. & Rate & No. & Rate & No. & Rate & No. & Rate & No. & Rate & No. & Rate & No. & Total \\
\hline \multicolumn{17}{|c|}{ Arboviral diseases $^{\dagger}$} \\
\hline \multicolumn{17}{|c|}{ California serogroup viruses } \\
\hline neuroinvasive & 2 & $(0.05)$ & 12 & $(0.08)$ & 59 & $(0.14)$ & 2 & $(0.00)$ & 2 & $(0.00)$ & 3 & $(0.00)$ & 5 & $(0.01)$ & - & 85 \\
\hline nonneuroinvasive & - & $(0.00)$ & - & $(0.00)$ & 4 & $(0.01)$ & 2 & $(0.00)$ & 2 & $(0.00)$ & 1 & $(0.00)$ & 2 & $(0.00)$ & - & 11 \\
\hline Eastern equine enceph & alitis vir & & & & & & & & & & & & & & & \\
\hline neuroinvasive & - & $(0.00)$ & - & $(0.00)$ & - & $(0.00)$ & - & $(0.00)$ & 1 & $(0.00)$ & 4 & $(0.00)$ & 3 & $(0.01)$ & - & 8 \\
\hline Powassan virus & & & & & & & & & & & & & & & & \\
\hline neuroinvasive & - & $(0.00)$ & - & $(0.00)$ & - & $(0.00)$ & 1 & $(0.00)$ & - & $(0.00)$ & 2 & $(0.00)$ & 4 & $(0.01)$ & - & 7 \\
\hline nonneuroinvasive & - & $(0.00)$ & - & $(0.00)$ & - & $(0.00)$ & - & $(0.00)$ & - & $(0.00)$ & - & $(0.00)$ & 1 & $(0.00)$ & - & 1 \\
\hline St. Louis encephalitis vi & & & & & & & & & & & & & & & & \\
\hline neuroinvasive & - & $(0.00)$ & - & $(0.00)$ & - & $(0.00)$ & - & $(0.00)$ & 2 & $(0.00)$ & 4 & $(0.00)$ & - & $(0.00)$ & - & 6 \\
\hline nonneuroinvasive & - & $(0.00)$ & - & $(0.00)$ & - & $(0.00)$ & - & $(0.00)$ & - & $(0.00)$ & 2 & $(0.00)$ & 2 & $(0.00)$ & - & 4 \\
\hline West Nile virus & & & & & & & & & & & & & & & & \\
\hline neuroinvasive & 2 & $(0.05)$ & - & $(0.00)$ & 26 & $(0.06)$ & 54 & $(0.12)$ & 150 & $(0.24)$ & 633 & $(0.61)$ & 481 & $(1.04)$ & 1 & 1,347 \\
\hline nonneuroinvasive & - & $(0.00)$ & 3 & $(0.02)$ & 13 & $(0.03)$ & 53 & $(0.12)$ & 137 & $(0.22)$ & 432 & $(0.41)$ & 220 & $(0.48)$ & - & 858 \\
\hline Babesiosis, total & 1 & $(0.04)$ & 10 & $(0.09)$ & 33 & $(0.12)$ & 48 & $(0.17)$ & 144 & $(0.34)$ & 700 & (1.03) & 816 & $(2.80)$ & 8 & 1,760 \\
\hline confirmed & 1 & $(0.04)$ & 8 & $(0.08)$ & 23 & $(0.08)$ & 30 & $(0.10)$ & 114 & $(0.27)$ & 575 & $(0.84)$ & 715 & $(2.46)$ & 6 & 1,472 \\
\hline probable & - & $(0.00)$ & 2 & $(0.02)$ & 10 & $(0.04)$ & 18 & $(0.06)$ & 30 & $(0.07)$ & 125 & $(0.18)$ & 101 & $(0.35)$ & 2 & 288 \\
\hline Botulism, total & 127 & (3.22) & 1 & $(0.01)$ & 1 & $(0.00)$ & 4 & $(0.01)$ & 6 & $(0.01)$ & 18 & $(0.02)$ & 4 & $(0.01)$ & - & 161 \\
\hline foodborne & 1 & $(0.03)$ & - & $(0.00)$ & 1 & $(0.00)$ & 3 & $(0.01)$ & 1 & $(0.00)$ & 6 & $(0.01)$ & 3 & $(0.01)$ & - & 15 \\
\hline Infant & 126 & (3.19) & 1 & $(0.01)$ & - & $(0.00)$ & - & $(0.00)$ & - & $(0.00)$ & - & $(0.00)$ & - & $(0.00)$ & - & 127 \\
\hline $\begin{array}{l}\text { other (wound } \\
\text { and unspecified) }\end{array}$ & - & $(0.00)$ & - & $(0.00)$ & - & $(0.00)$ & 1 & $(0.00)$ & 5 & $(0.01)$ & 12 & $(0.01)$ & 1 & $(0.00)$ & - & 19 \\
\hline Brucellosis & - & $(0.00)$ & 3 & $(0.02)$ & 2 & $(0.00)$ & 13 & $(0.03)$ & 18 & $(0.03)$ & 32 & $(0.03)$ & 22 & $(0.05)$ & 2 & 92 \\
\hline Chancroid $^{\S}$ & - & $(0.00)$ & - & $(0.00)$ & - & $(0.00)$ & 3 & $(0.01)$ & 2 & $(0.00)$ & 1 & $(0.00)$ & - & $(0.00)$ & - & 6 \\
\hline $\begin{array}{l}\text { Chlamydia trachomatis, } \\
\text { infection }\end{array}$ & - & $(0.00)$ & - & $(0.00)$ & - & $(0.00)$ & 948,102 & (2155.77) & 419,569 & (61.38) & 58,726 & $(56.40)$ & 1,449 & (3.13) & 1,753 & $1,441,789 * *$ \\
\hline Cholera & - & $(0.00)$ & 1 & $(0.01)$ & - & $(0.00)$ & - & $(0.00)$ & 1 & $(0.00)$ & 3 & $(0.00)$ & - & $(0.00)$ & - & 5 \\
\hline Coccidioidomycosis" & 4 & $(0.26)$ & 27 & $(0.43)$ & 256 & (1.58) & 720 & $(4.14)$ & 1,532 & (6.13) & 3,434 & $(8.47)$ & 2,232 & (12.54) & 27 & 8,232 \\
\hline Cryptosporidiosis, total & 158 & $(4.00)$ & 1,313 & (8.24) & 1,201 & $(2.92)$ & 1,262 & $(2.87)$ & 1,975 & (3.11) & 1,873 & $(1.80)$ & 883 & $(1.91)$ & 17 & 8,682 \\
\hline confirmed & 90 & $(2.28)$ & 923 & (5.79) & 817 & (1.98) & 862 & (1.96) & 1,272 & $(2.01)$ & 1,133 & (1.09) & 457 & (0.99) & 11 & 5,565 \\
\hline probable & 68 & $(1.72)$ & 390 & $(2.45)$ & 384 & $(0.93)$ & 400 & $(0.91)$ & 703 & $(1.11)$ & 740 & $(0.71)$ & 426 & $(0.92)$ & 6 & 3,117 \\
\hline Cyclosporiasis & - & $(0.00)$ & 2 & $(0.01)$ & 1 & $(0.00)$ & 21 & $(0.05)$ & 74 & $(0.13)$ & 214 & $(0.23)$ & 85 & $(0.20)$ & 1 & 398 \\
\hline Dengue fever ${ }^{\dagger}$ & 1 & $(0.03)$ & 1 & $(0.01)$ & 28 & $(0.07)$ & 86 & $(0.20)$ & 167 & $(0.26)$ & 312 & $(0.30)$ & 83 & $(0.18)$ & 2 & 680 \\
\hline Diphtheria & - & $(0.00)$ & - & $(0.00)$ & - & $(0.00)$ & 1 & $(0.00)$ & - & $(0.00)$ & - & $(0.00)$ & - & $(0.00)$ & - & 1 \\
\hline Ehrlichiosis/Anaplasmos & & & & & & & & & & & & & & & & \\
\hline $\begin{array}{l}\text { Anaplasma } \\
\text { phagocytophilum }\end{array}$ & - & $(0.00)$ & 10 & $(0.07)$ & 99 & $(0.25)$ & 127 & $(0.30)$ & 245 & $(0.40)$ & 1,241 & $(1.25)$ & 1,072 & $(2.42)$ & 6 & 2,800 \\
\hline Ehrlichia chaffeensis & 1 & $(0.03)$ & 9 & $(0.06)$ & 36 & $(0.09)$ & 85 & $(0.20)$ & 151 & $(0.25)$ & 657 & $(0.66)$ & 526 & (1.19) & 10 & 1,475 \\
\hline Ehrlichia ewingii & - & $(0.00)$ & - & $(0.00)$ & - & $(0.00)$ & - & $(0.00)$ & 4 & $(0.01)$ & 7 & $(0.01)$ & 6 & $(0.01)$ & - & 17 \\
\hline undetermined & - & $(0.00)$ & 1 & $(0.01)$ & 8 & $(0.02)$ & 17 & $(0.04)$ & 25 & $(0.04)$ & 75 & $(0.08)$ & 69 & $(0.16)$ & 1 & 196 \\
\hline Giardiasis & 103 & (3.37) & 1,720 & (13.95) & 1,960 & (6.15) & 1,823 & (5.29) & 2,891 & $(5.81)$ & 4,493 & $(5.44)$ & 1,489 & $(4.00)$ & 75 & 14,554 \\
\hline Gonorrhea ${ }^{\S}$ & - & $(0.00)$ & - & $(0.00)$ & - & $(0.00)$ & 184,668 & (419.89) & 128,783 & $(203.01)$ & 32,558 & (31.27) & 911 & (1.97) & 485 & $350,062^{* *}$ \\
\hline Haemophilus influenzae, & nvasive & lisease & & & & & & & & & & & & & & \\
\hline $\begin{array}{l}\text { all ages, serotypes } \\
\text { age }<5 \text { yrs }\end{array}$ & 277 & $(7.02)$ & 195 & $(1.22)$ & 97 & $(0.24)$ & 80 & $(0.18)$ & 211 & $(0.33)$ & 876 & $(0.84)$ & 1,800 & (3.89) & 5 & 3,541 \\
\hline serotype b & 25 & $(0.63)$ & 15 & $(0.09)$ & - & $(0.00)$ & - & $(0.00)$ & - & $(0.00)$ & - & $(0.00)$ & - & $(0.00)$ & - & 40 \\
\hline nontypeable & 86 & $(2.42)$ & 42 & $(0.25)$ & - & $(0.00)$ & - & $(0.00)$ & - & $(0.00)$ & - & $(0.00)$ & - & $(0.00)$ & - & 128 \\
\hline non-b serotype & 20 & $(1.52)$ & 18 & $(0.10)$ & - & $(0.00)$ & - & $(0.00)$ & - & $(0.00)$ & - & $(0.00)$ & - & $(0.00)$ & - & 38 \\
\hline unknown serotype & 146 & $(4.10)$ & 120 & $(0.83)$ & - & $(0.00)$ & - & $(0.00)$ & - & $(0.00)$ & - & $(0.00)$ & - & $(0.00)$ & - & 266 \\
\hline Hansen's disease & - & $(0.00)$ & - & $(0.00)$ & 3 & $(0.01)$ & 7 & $(0.02)$ & 22 & $(0.04)$ & 22 & $(0.02)$ & 19 & $(0.05)$ & 15 & 88 \\
\hline $\begin{array}{l}\text { Hantavirus pulmonary } \\
\text { syndrome }\end{array}$ & - & $(0.00)$ & - & $(0.00)$ & 2 & $(0.01)$ & 2 & $(0.00)$ & 12 & $(0.02)$ & 13 & $(0.01)$ & 3 & $(0.01)$ & - & 32 \\
\hline $\begin{array}{l}\text { Hemolytic uremic } \\
\text { syndrome } \\
\text { postdiarrheal }\end{array}$ & 6 & $(0.15)$ & 117 & $(0.73)$ & 87 & $(0.21)$ & 12 & $(0.03)$ & 2 & $(0.00)$ & 16 & $(0.02)$ & 8 & $(0.02)$ & 2 & 250 \\
\hline Hepatitis,virus & & & & & & & & & & & & & & & & \\
\hline A acute & 2 & $(0.05)$ & 13 & $(0.08)$ & 68 & $(0.17)$ & 181 & $(0.41)$ & 344 & $(0.54)$ & 407 & $(0.39)$ & 217 & $(0.47)$ & 7 & 1,239 \\
\hline B acute & - & $(0.00)$ & 1 & $(0.01)$ & 1 & $(0.00)$ & 102 & $(0.23)$ & 1,080 & $(1.72)$ & 1,436 & (1.39) & 157 & $(0.34)$ & 14 & 2,791 \\
\hline B chronic & 13 & $(0.41)$ & 28 & $(0.22)$ & 79 & $(0.24)$ & 821 & $(2.30)$ & 4,316 & (8.39) & 5,705 & $(6.67)$ & 1,064 & $(2.75)$ & 374 & 12,400 \\
\hline B infection perinatal & 24 & $(0.62)$ & 23 & $(0.15)$ & - & $(0.00)$ & - & $(0.00)$ & - & $(0.00)$ & - & $(0.00)$ & - & $(0.00)$ & - & 47 \\
\hline Cacute & 11 & $(0.30)$ & 3 & $(0.02)$ & 1 & $(0.00)$ & 502 & $(1.21)$ & 1,139 & $(1.90)$ & 482 & $(0.49)$ & 38 & $(0.09)$ & 28 & 2,204 \\
\hline $\mathrm{C}$ past or present & 232 & (7.68) & 138 & (1.13) & 142 & $(0.45)$ & 14,420 & $(42.41)$ & 42,430 & (86.33) & 87,854 & (107.79) & 13,470 & (36.85) & 4,177 & 162,863 \\
\hline $\begin{array}{l}\text { Human } \\
\text { immunodeficiency } \\
\text { virus (HIV) } \\
\text { diagnoses }^{\dagger+}\end{array}$ & 34 & $(0.90)$ & 24 & $(0.20)$ & 95 & $(0.20)$ & 7,723 & $(17.60)$ & 14,927 & (23.50) & 12,059 & (11.60) & 744 & $(1.60)$ & - & 35,606 \\
\hline
\end{tabular}


TABLE 3. (Continued) Number of reported cases of notifiable diseases* and rates per 100,000 population, by age group, excluding U.S. territories - United States, 2014

\begin{tabular}{|c|c|c|c|c|c|c|c|c|c|c|c|c|c|c|c|c|}
\hline \multirow[b]{2}{*}{ Disease } & \multicolumn{2}{|c|}{$<1 \mathrm{yr}$} & \multicolumn{2}{|c|}{$1-4$ yrs } & \multicolumn{2}{|c|}{$5-14$ yrs } & \multicolumn{2}{|c|}{$15-24$ yrs } & \multicolumn{2}{|c|}{$25-39$ yrs } & \multicolumn{2}{|c|}{$40-64$ yrs } & \multicolumn{2}{|c|}{$\geq 65$ yrs } & \multicolumn{2}{|c|}{ Age not stated } \\
\hline & No. & Rate & No. & Rate & No. & Rate & No. & Rate & No. & Rate & No. & Rate & No. & Rate & No. & Total \\
\hline $\begin{array}{l}\text { Influenza-associated } \\
\text { pediatric mortality }\end{array}$ & 33 & $(0.84)$ & 31 & $(0.19)$ & 61 & $(0.15)$ & 16 & $(0.13)$ & - & $(0.00)$ & - & $(0.00)$ & - & $(0.00)$ & - & 141 \\
\hline \multicolumn{17}{|c|}{ Invasive pneumococcal disease } \\
\hline all ages & 363 & (13.42) & 660 & $(6.05)$ & 372 & $(1.32)$ & 262 & $(0.87)$ & 1,161 & $(2.69)$ & 6,407 & $(8.95)$ & 6,103 & (19.06) & 28 & 15,356 \\
\hline age $<5$ yrs & 378 & (12.78) & 687 & $(5.75)$ & - & $(0.00)$ & - & $(0.00)$ & - & $(0.00)$ & - & $(0.00)$ & - & $(0.00)$ & - & 1,065 \\
\hline Legionellosis & 1 & $(0.03)$ & - & $(0.00)$ & 2 & $(0.00)$ & 37 & $(0.08)$ & 335 & $(0.53)$ & 2,374 & $(2.28)$ & 2,185 & $(4.73)$ & 232 & 5,166 \\
\hline Leptospirosis & - & $(0.00)$ & - & $(0.00)$ & 2 & $(0.01)$ & 11 & $(0.03)$ & 9 & $(0.02)$ & 11 & $(0.01)$ & 2 & $(0.01)$ & 3 & 38 \\
\hline Listeriosis & 48 & $(1.22)$ & 2 & $(0.01)$ & 5 & $(0.01)$ & 19 & $(0.04)$ & 67 & $(0.11)$ & 187 & $(0.18)$ & 438 & $(0.95)$ & 3 & 769 \\
\hline Lyme disease, total & 36 & $(0.92)$ & 1,263 & (7.97) & 5,649 & (13.77) & 3,337 & (7.62) & 4,092 & $(6.48)$ & 11,968 & (11.54) & 6,310 & (13.71) & 806 & 33,461 \\
\hline confirmed & 26 & $(0.66)$ & 1,100 & (6.94) & 4,502 & (10.97) & 2,384 & $(5.44)$ & 3,019 & $(4.78)$ & 9,115 & (8.79) & 4,543 & (9.87) & 670 & 25,359 \\
\hline probable & 10 & $(0.25)$ & 163 & (1.03) & 1,147 & $(2.80)$ & 953 & (2.18) & 1,073 & $(1.70)$ & 2,853 & $(2.75)$ & 1,767 & (3.84) & 136 & 8,102 \\
\hline Malaria & 6 & $(0.15)$ & 49 & $(0.31)$ & 128 & $(0.31)$ & 255 & $(0.58)$ & 512 & $(0.81)$ & 584 & $(0.56)$ & 115 & $(0.25)$ & 4 & 1,653 \\
\hline Measles, total & 49 & $(1.24)$ & 102 & $(0.64)$ & 150 & $(0.36)$ & 156 & $(0.35)$ & 134 & $(0.21)$ & 75 & $(0.07)$ & 1 & $(0.00)$ & - & 667 \\
\hline Indigenous & 41 & $(1.04)$ & 90 & $(0.57)$ & 146 & $(0.35)$ & 142 & $(0.32)$ & 120 & $(0.19)$ & 64 & $(0.06)$ & 1 & $(0.00)$ & - & 604 \\
\hline Imported & 8 & $(0.20)$ & 12 & $(0.08)$ & 4 & $(0.01)$ & 14 & $(0.03)$ & 14 & $(0.02)$ & 11 & $(0.01)$ & - & $(0.00)$ & - & 63 \\
\hline \multicolumn{17}{|l|}{ Meningococcal disease } \\
\hline all serogroups & 42 & $(1.06)$ & 40 & $(0.25)$ & 18 & $(0.04)$ & 63 & $(0.14)$ & 68 & $(0.11)$ & 119 & $(0.11)$ & 83 & $(0.18)$ & - & 433 \\
\hline serogroups ACWY & 6 & $(0.15)$ & 11 & $(0.07)$ & 4 & $(0.01)$ & 6 & $(0.01)$ & 21 & $(0.03)$ & 40 & $(0.04)$ & 35 & $(0.08)$ & - & 123 \\
\hline serogroup B & 16 & $(0.41)$ & 12 & $(0.08)$ & 5 & $(0.01)$ & 24 & $(0.05)$ & 10 & $(0.02)$ & 16 & $(0.02)$ & 6 & $(0.01)$ & - & 89 \\
\hline other serogroups & 6 & $(0.15)$ & - & $(0.00)$ & 1 & $(0.00)$ & 7 & $(0.02)$ & 2 & $(0.00)$ & 7 & $(0.01)$ & 2 & $(0.00)$ & - & 25 \\
\hline unknown serogroup & 14 & $(0.35)$ & 17 & $(0.11)$ & 8 & $(0.02)$ & 26 & $(0.06)$ & 35 & $(0.06)$ & 56 & $(0.05)$ & 40 & $(0.09)$ & - & 196 \\
\hline Mumps & 6 & $(0.15)$ & 62 & $(0.39)$ & 118 & $(0.29)$ & 481 & $(1.09)$ & 242 & $(0.38)$ & 269 & $(0.26)$ & 44 & $(0.10)$ & 1 & 1,223 \\
\hline $\begin{array}{l}\text { Novel influenza A } \\
\text { virus infection }\end{array}$ & - & $(0.00)$ & - & $(0.00)$ & 2 & $(0.00)$ & - & $(0.00)$ & - & $(0.00)$ & - & $(0.00)$ & - & $(0.00)$ & 1 & 3 \\
\hline Pertussis & 4,155 & $(105.23)$ & 4,418 & $(27.74)$ & 12,945 & (31.43) & 6,027 & (13.70) & 1,820 & $(2.87)$ & 2,734 & $(2.63)$ & 750 & $(1.62)$ & 122 & 32,971 \\
\hline Plague & - & $(0.00)$ & - & $(0.00)$ & - & $(0.00)$ & 1 & $(0.00)$ & 4 & $(0.01)$ & 5 & $(0.00)$ & - & $(0.00)$ & - & 10 \\
\hline Psittacosis & - & $(0.00)$ & - & $(0.00)$ & - & $(0.00)$ & 1 & $(0.00)$ & 1 & $(0.00)$ & 4 & $(0.00)$ & 2 & $(0.00)$ & - & 8 \\
\hline Q fever, total & - & $(0.00)$ & - & $(0.00)$ & 1 & $(0.00)$ & 7 & $(0.02)$ & 22 & $(0.04)$ & 92 & $(0.09)$ & 42 & $(0.09)$ & 4 & 168 \\
\hline acute & - & $(0.00)$ & - & $(0.00)$ & 1 & $(0.00)$ & 7 & $(0.02)$ & 21 & $(0.03)$ & 73 & $(0.07)$ & 27 & $(0.06)$ & 3 & 132 \\
\hline chronic & - & $(0.00)$ & - & $(0.00)$ & - & $(0.00)$ & - & $(0.00)$ & 1 & $(0.00)$ & 19 & $(0.02)$ & 15 & $(0.03)$ & 1 & 36 \\
\hline Rabies, human & - & $(0.00)$ & - & $(0.00)$ & - & $(0.00)$ & - & $(0.00)$ & - & $(0.00)$ & 1 & $(0.00)$ & - & $(0.00)$ & - & 1 \\
\hline Rubella & - & $(0.00)$ & - & $(0.00)$ & - & $(0.00)$ & 3 & $(0.01)$ & 2 & $(0.00)$ & 1 & $(0.00)$ & - & $(0.00)$ & - & 6 \\
\hline $\begin{array}{l}\text { Rubella, } \\
\text { congenital syndrome }\end{array}$ & - & $(0.00)$ & 1 & $(0.01)$ & - & $(0.00)$ & - & $(0.00)$ & - & $(0.00)$ & - & $(0.00)$ & - & $(0.00)$ & - & 1 \\
\hline Salmonellosis & 5,135 & (130.05) & 7,357 & $(46.19)$ & 6,173 & (14.99) & 5,136 & $(11.68)$ & 7,093 & $(11.18)$ & 12,337 & $(11.85)$ & 7,929 & $(17.15)$ & 295 & 51,455 \\
\hline $\begin{array}{l}\text { Shiga toxin-producing } \\
\text { E. coli (STEC) }\end{array}$ & 205 & (5.19) & 1,433 & $(9.00)$ & 1,208 & $(2.93)$ & 1,041 & $(2.37)$ & 855 & (1.35) & 830 & $(0.80)$ & 569 & $(1.23)$ & 38 & 6,179 \\
\hline Shigellosis & 309 & (7.83) & 5,600 & (35.16) & 6,303 & (15.30) & 1,566 & $(3.56)$ & 3,203 & $(5.05)$ & 2,866 & $(2.75)$ & 779 & (1.68) & 119 & 20,745 \\
\hline $\begin{array}{l}\text { Spotted fever } \\
\text { rickettsiosis, total }\end{array}$ & 5 & $(0.13)$ & 38 & $(0.23)$ & 175 & $(0.43)$ & 293 & $(0.66)$ & 650 & $(1.03)$ & 1,745 & $(1.68)$ & 838 & $(.82)$ & 13 & 3,757 \\
\hline confirmed & 1 & $(0.03)$ & 5 & $(0.03)$ & 6 & $(0.01)$ & 10 & $(0.02)$ & 18 & $(0.03)$ & 46 & $(0.04)$ & 29 & $(0.06)$ & - & 115 \\
\hline probable & 4 & $(0.10)$ & 33 & $(0.20)$ & 169 & $(0.41)$ & 282 & $(0.64)$ & 630 & $(1.00)$ & 1,695 & $(1.63)$ & 808 & $(1.76)$ & 13 & 3,634 \\
\hline $\begin{array}{l}\text { Streptococcal toxic } \\
\text { shock syndrome }\end{array}$ & 1 & $(0.04)$ & 5 & $(0.05)$ & 10 & $(0.04)$ & 16 & $(0.05)$ & 40 & $(0.10)$ & 117 & $(0.16)$ & 70 & $(0.22)$ & - & 259 \\
\hline $\begin{array}{l}\text { Syphilis, total, } \\
\text { all stages }{ }^{\S, \text {, }}\end{array}$ & - & $(0.00)$ & - & $(0.00)$ & - & $(0.00)$ & 13,653 & (31.04) & 27,286 & $(43.01)$ & 20,572 & (19.76) & 1,404 & $(3.04)$ & 18 & $63,450 * *$ \\
\hline $\begin{array}{l}\text { primary and } \\
\text { secondary }\end{array}$ & - & $(0.00)$ & - & $(0.00)$ & - & $(0.00)$ & 5,160 & $(11.73)$ & 9,024 & $(14.22)$ & 5,621 & $(5.40)$ & 176 & $(0.38)$ & 6 & $19,999^{* *}$ \\
\hline congenital $^{\S}$ & - & $(0.00)$ & - & $(0.00)$ & - & $(0.00)$ & - & $(0.00)$ & - & $(0.00)$ & - & $(0.00)$ & - & $(0.00)$ & - & $458^{* * *}$ \\
\hline Tetanus & - & $(0.00)$ & 1 & $(0.01)$ & 3 & $(0.01)$ & 1 & $(0.00)$ & 5 & $(0.01)$ & 5 & $(0.00)$ & 5 & $(0.01)$ & 5 & 25 \\
\hline $\begin{array}{l}\text { Toxic shock syndrome } \\
\text { (other than } \\
\text { streptococcal) }\end{array}$ & - & $(0.00)$ & 2 & $(0.02)$ & 18 & $(0.06)$ & 22 & $(0.07)$ & 3 & $(0.01)$ & 10 & $(0.01)$ & - & $(0.00)$ & 4 & 59 \\
\hline Trichinellosis & - & $(0.00)$ & - & $(0.00)$ & 1 & $(0.00)$ & - & $(0.00)$ & 5 & $(0.01)$ & 5 & $(0.01)$ & 2 & $(0.00)$ & - & 13 \\
\hline Tuberculosis*** & 45 & $(1.14)$ & 217 & $(1.36)$ & 198 & $(0.48)$ & 961 & $(2.19)$ & 2,150 & (3.39) & 3,634 & $(3.49)$ & 2,216 & $(4.79)$ & - & 9,421 \\
\hline Tularemia & 2 & $(0.05)$ & 6 & $(0.04)$ & 30 & $(0.07)$ & 16 & $(0.04)$ & 12 & $(0.02)$ & 68 & $(0.07)$ & 44 & $(0.10)$ & 2 & 180 \\
\hline Typhoid fever & 3 & $(0.08)$ & 31 & $(0.19)$ & 80 & $(0.19)$ & 57 & $(0.13)$ & 102 & $(0.16)$ & 56 & $(0.05)$ & 18 & $(0.04)$ & 2 & 349 \\
\hline $\begin{array}{l}\text { Vancomycin- } \\
\text { intermediate } \\
\text { Staphylococcus aureus } \\
\text { (VISA) }\end{array}$ & 1 & $(0.03)$ & 1 & $(0.01)$ & - & $(0.00)$ & 11 & $(0.03)$ & 20 & $(0.04)$ & 110 & $(0.13)$ & 65 & $(0.17)$ & 4 & 212 \\
\hline Vibriosis & 1 & $(0.03)$ & 9 & $(0.06)$ & 108 & $(0.28)$ & 93 & $(0.23)$ & 239 & $(0.40)$ & 550 & $(0.56)$ & 254 & $(0.59)$ & 7 & 1,261 \\
\hline $\begin{array}{l}\text { Viral hemorrhagic } \\
\text { fevers }\end{array}$ & - & $(0.00)$ & - & $(0.00)$ & - & $(0.00)$ & - & $(0.00)$ & 3 & $(0.01)$ & 1 & $(0.00)$ & - & $(0.00)$ & 1 & 5 \\
\hline Yellow fever ${ }^{\dagger}$ & - & $(0.00)$ & - & $(0.00)$ & - & $(0.00)$ & - & $(0.00)$ & - & $(0.00)$ & - & $(0.00)$ & - & $(0.00)$ & - & - \\
\hline
\end{tabular}

See table footnotes on page 62 . 
TABLE 3. (Continued) Number of reported cases of notifiable diseases* and rates per 100,000 population, by age group, excluding U.S. territories - United States, 2014

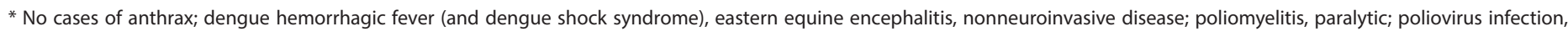

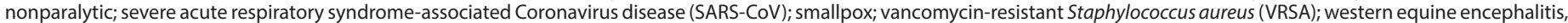
neuroinvasive and nonneuroinvasive disease; or yellow fever were reported in the United States during 2014.

† Totals reported to the Division of Vector-Borne Diseases, National Center for Emerging and Zoonotic Infectious Diseases (ArboNET Surveillance), as of July 1, 2015.

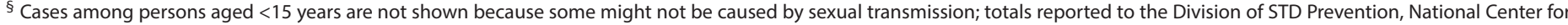
HIV/AIDS, Viral Hepatitis, STD, and TB Prevention (NCHHSTP), as of June 10, 2015.

I Reportable in $<25$ states.

** The row totals do not sum to total column. Data are suppressed for those aged $<15$ years. The total reflects the total count across all age groups.

t† Total number of HIV diagnoses reported to the Division of HIV/AIDS Prevention, NCHHSTP through December 31, 2014.

$\S \S$ Totals reported to the Influenza Division, National Center for Immunization and Respiratory Diseases (NCIRD) as of June 30, 2015.

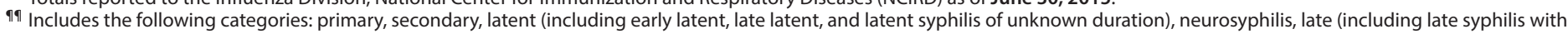
clinical manifestations other than neurosyphilis), and congenital syphilis. Totals reported to the Division of STD Prevention, NCHHSTP, as of June 10, 2015.

*** Totals reported to the Division of Tuberculosis Elimination, NCHHSTP, as of July 15, 2015.
} 
TABLE 4. Number of reported cases of notifiable diseases* and rates per 100,000 population, by sex, excluding U.S. territories — United States, 2014

\begin{tabular}{|c|c|c|c|c|c|c|}
\hline \multirow[b]{2}{*}{ Disease } & \multicolumn{2}{|c|}{ Male } & \multicolumn{2}{|c|}{ Female } & \multicolumn{2}{|c|}{ Sex not stated } \\
\hline & No. & Rate & No. & Rate & No. & Total \\
\hline \multicolumn{7}{|l|}{ Arboviral diseases $^{\dagger}$} \\
\hline \multicolumn{7}{|l|}{ California serogroup viruses } \\
\hline neuroinvasive & 42 & $(0.03)$ & 43 & $(0.03)$ & - & 85 \\
\hline nonneuroinvasive & 6 & $(0.00)$ & 5 & $(0.00)$ & - & 11 \\
\hline \multicolumn{7}{|l|}{ Eastern equine encephalitis virus } \\
\hline neuroinvasive & 4 & $(0.00)$ & 4 & $(0.00)$ & - & 8 \\
\hline \multicolumn{7}{|l|}{ Powassan virus } \\
\hline neuroinvasive & 5 & $(0.00)$ & 2 & $(0.00)$ & - & 7 \\
\hline nonneuroinvasive & 1 & $(0.00)$ & - & $(0.00)$ & - & 1 \\
\hline \multicolumn{7}{|l|}{ St. Louis encephalitis virus } \\
\hline neuroinvasive & 3 & $(0.00)$ & 3 & $(0.00)$ & - & 6 \\
\hline nonneuroinvasive & 1 & $(0.00)$ & 3 & $(0.00)$ & - & 4 \\
\hline \multicolumn{7}{|l|}{ West Nile virus } \\
\hline neuroinvasive & 881 & $(0.57)$ & 466 & $(0.29)$ & - & 1,347 \\
\hline nonneuroinvasive & 522 & $(0.33)$ & 336 & $(0.21)$ & - & 858 \\
\hline Babesiosis, total & 1,138 & $(1.11)$ & 616 & $(0.58)$ & 6 & 1,760 \\
\hline confirmed & 969 & $(0.94)$ & 498 & $(0.47)$ & 5 & 1,472 \\
\hline probable & 169 & $(0.16)$ & 118 & $(0.11)$ & 1 & 288 \\
\hline Botulism, total & 93 & $(0.06)$ & 68 & $(0.04)$ & - & 161 \\
\hline foodborne & 7 & $(0.00)$ & 8 & $(0.00)$ & - & 15 \\
\hline infant & 71 & $(3.52)$ & 56 & $(2.90)$ & - & 127 \\
\hline other (wound and unspecified) & 15 & $(0.01)$ & 4 & $(0.00)$ & - & 19 \\
\hline Brucellosis & 58 & $(0.04)$ & 34 & $(0.02)$ & - & 92 \\
\hline Chancroid ${ }^{\S}$ & 4 & $(0.00)$ & 2 & $(0.00)$ & - & 6 \\
\hline Chlamydia trachomatis, infection $\S$ & 433,325 & $(276.11)$ & $1,006,441$ & $(621.56)$ & 2,023 & $1,441,789$ \\
\hline Cholera & 4 & $(0.00)$ & 1 & $(0.00)$ & - & 5 \\
\hline Coccidioidomycosis" & 4,283 & $(6.96)$ & 3,940 & $(6.24)$ & 9 & 8,232 \\
\hline Cryptosporidiosis, total & 4,289 & $(2.73)$ & 4,361 & $(2.69)$ & 32 & 8,682 \\
\hline confirmed & 2,775 & $(1.77)$ & 2,763 & $(1.71)$ & 27 & 5,565 \\
\hline probable & 1,514 & $(0.96)$ & 1,598 & $(0.99)$ & 5 & 3,117 \\
\hline Cyclosporiasis & 179 & $(0.12)$ & 218 & $(0.15)$ & 1 & 398 \\
\hline Dengue fever ${ }^{\dagger}$ & 324 & $(0.21)$ & 356 & $(0.22)$ & - & 680 \\
\hline Diphtheria & - & $(0.00)$ & 1 & $(0.00)$ & - & 1 \\
\hline \multicolumn{7}{|l|}{ Ehrlichiosis/Anaplasmosis } \\
\hline Anaplasma phagocytophilum & 1,714 & $(1.14)$ & 1,079 & $(0.70)$ & 7 & 2,800 \\
\hline Ehrlichia chaffeensis & 874 & $(0.58)$ & 596 & $(0.39)$ & 5 & 1,475 \\
\hline Ehrlichia ewingii & 11 & $(0.01)$ & 6 & $(0.00)$ & - & 17 \\
\hline undetermined & 113 & $(0.08)$ & 83 & $(0.05)$ & - & 196 \\
\hline Giardiasis & 8,652 & $(7.00)$ & 5,712 & $(4.48)$ & 190 & 14,554 \\
\hline Gonorrhea ${ }^{\S}$ & 186,943 & $(119.12)$ & 162,608 & $(100.42)$ & 511 & 350,062 \\
\hline \multicolumn{7}{|l|}{ Haemophilus influenzae, invasive disease } \\
\hline all ages, serotypes & 1,651 & $(1.05)$ & 1,868 & $(1.15)$ & 22 & 3,541 \\
\hline age $<5$ yrs & & & & & & \\
\hline serotype b & 19 & $(0.19)$ & 21 & $(0.22)$ & - & 40 \\
\hline nontypeable & 74 & $(0.73)$ & 53 & $(0.55)$ & 1 & 128 \\
\hline non-b serotype & 24 & $(0.24)$ & 13 & (0.13) & 1 & 38 \\
\hline unknown serotype & 157 & $(1.55)$ & 104 & $(1.07)$ & 5 & 266 \\
\hline Hansen's disease & 48 & $(0.03)$ & 25 & $(0.02)$ & 15 & 88 \\
\hline Hantavirus pulmonary syndrome & 25 & $(0.02)$ & 7 & $(0.00)$ & - & 32 \\
\hline Hemolytic uremic syndrome postdiarrheal & 99 & $(0.06)$ & 151 & $(0.09)$ & - & 250 \\
\hline Hepatitis, virus & & & & & & \\
\hline A acute & 645 & $(0.41)$ & 591 & $(0.37)$ & 3 & 1,239 \\
\hline B acute & 1,778 & $(1.14)$ & 1,001 & $(0.62)$ & 12 & 2,791 \\
\hline B chronic & 6,782 & $(5.30)$ & 5,473 & $(4.14)$ & 145 & 12,400 \\
\hline B infection perinatal & 25 & $(0.02)$ & 22 & $(0.01)$ & - & 47 \\
\hline Cacute & 1,173 & $(0.79)$ & 1,029 & $(0.67)$ & 2 & 2,204 \\
\hline C past or present & 98,372 & (80.68) & 63,550 & (50.46) & 941 & 162,863 \\
\hline Human immunodeficiency virus (HIV) diagnoses ${ }^{* *}$ & 28,806 & $(18.40)$ & 6,800 & $(4.20)$ & - & 35,606 \\
\hline Influenza-associated pediatric mortality ${ }^{+\dagger}$ & 69 & $(0.18)$ & 72 & $(0.20)$ & - & 141 \\
\hline Invasive pneumococcal disease & & & & & & \\
\hline all ages & 7,967 & $(7.41)$ & 7,321 & (6.58) & 68 & 15,356 \\
\hline age $<5$ yrs & 567 & $(7.44)$ & 443 & $(6.08)$ & 55 & 1,065 \\
\hline Legionellosis & 3,050 & $(1.94)$ & 2,112 & $(1.30)$ & 4 & 5,166 \\
\hline Leptospirosis & 30 & $(0.02)$ & 8 & $(0.01)$ & - & 38 \\
\hline Listeriosis & 368 & $(0.23)$ & 399 & $(0.25)$ & 2 & 769 \\
\hline
\end{tabular}

See table footnotes on next page. 
TABLE 4. (Continued) Number of reported cases of notifiable diseases* and rates per 100,000 population, by sex, excluding U.S. territories United States, 2014

\begin{tabular}{|c|c|c|c|c|c|c|}
\hline \multirow[b]{2}{*}{ Disease } & \multicolumn{2}{|c|}{ Male } & \multicolumn{2}{|c|}{ Female } & \multicolumn{2}{|c|}{ Sex not stated } \\
\hline & No. & Rate & No. & Rate & No. & Total \\
\hline Lyme disease, total & 19,180 & (12.28) & 13,841 & $(8.59)$ & 440 & 33,461 \\
\hline confirmed & 14,526 & $(9.30)$ & 10,485 & $(6.50)$ & 348 & 25,359 \\
\hline probable & 4,654 & $(2.98)$ & 3,356 & $(2.08)$ & 92 & 8,102 \\
\hline Malaria & 1,048 & $(0.67)$ & 598 & $(0.37)$ & 7 & 1,653 \\
\hline Measles, total & 357 & $(0.23)$ & 310 & $(0.19)$ & - & 667 \\
\hline indigenous & 319 & $(0.20)$ & 285 & $(0.18)$ & - & 604 \\
\hline imported & 38 & $(0.02)$ & 25 & $(0.02)$ & - & 63 \\
\hline \multicolumn{7}{|l|}{ Meningococcal disease } \\
\hline all serogroups & 223 & $(0.14)$ & 210 & $(0.13)$ & - & 433 \\
\hline serogroups ACWY & 61 & $(0.04)$ & 62 & $(0.04)$ & - & 123 \\
\hline serogroup B & 50 & $(0.03)$ & 39 & $(0.02)$ & - & 89 \\
\hline other serogroups & 12 & $(0.01)$ & 13 & $(0.01)$ & - & 25 \\
\hline unknown serogroup & 100 & $(0.06)$ & 96 & $(0.06)$ & - & 196 \\
\hline Mumps & 598 & $(0.38)$ & 624 & $(0.39)$ & 1 & 1,223 \\
\hline Novel influenza A virus infection & - & $(0.00)$ & 3 & $(0.00)$ & - & 3 \\
\hline Pertussis & 15,378 & (9.80) & 17,406 & $(10.75)$ & 187 & 32,971 \\
\hline Plague & 4 & $(0.00)$ & 6 & $(0.00)$ & - & 10 \\
\hline Psittacosis & 3 & $(0.00)$ & 5 & $(0.00)$ & - & 8 \\
\hline Q fever, total & 117 & $(0.08)$ & 51 & $(0.03)$ & - & 168 \\
\hline acute & 92 & $(0.06)$ & 40 & $(0.03)$ & - & 132 \\
\hline chronic & 25 & $(0.02)$ & 11 & $(0.01)$ & - & 36 \\
\hline Rabies, human & 1 & $(0.00)$ & & $(0.00)$ & - & 1 \\
\hline Rubella & 3 & $(0.00)$ & 3 & $(0.00)$ & - & 6 \\
\hline Rubella, congenital syndrome & - & $(0.00)$ & 1 & $(0.00)$ & - & 1 \\
\hline Salmonellosis & 23,965 & (15.27) & 27,086 & (16.73) & 404 & 51,455 \\
\hline Shiga toxin-producing E. coli (STEC) & 2,810 & $(1.79)$ & 3,348 & $(2.07)$ & 21 & 6,179 \\
\hline Shigellosis & 10,051 & $(6.40)$ & 10,368 & $(6.40)$ & 326 & 20,745 \\
\hline Spotted fever rickettsiosis, total & 2,610 & $(1.66)$ & 1,140 & $(0.70)$ & 7 & 3,757 \\
\hline confirmed & 90 & $(0.06)$ & 24 & $(0.01)$ & 1 & 115 \\
\hline probable & 2,515 & $(1.60)$ & 1,113 & $(0.68)$ & 6 & 3,634 \\
\hline Streptococcal toxic shock syndrome & 139 & $(0.13)$ & 120 & $(0.11)$ & - & 259 \\
\hline Syphilis, total, all stages $s^{\S, \S \S}$ & 51,774 & (32.99) & 11,180 & $(6.90)$ & 496 & 63,450 \\
\hline primary and secondary ${ }^{\S}$ & 18,146 & $(11.56)$ & 1,840 & $(1.14)$ & 13 & 19,999 \\
\hline congenital $^{\S}$ & 23 & $(1.14)$ & 19 & $(0.98)$ & 416 & 458 \\
\hline Tetanus & 9 & $(0.01)$ & 16 & $(0.01)$ & - & 25 \\
\hline Toxic shock syndrome (other than streptococcal) & 19 & $(0.02)$ & 40 & $(0.03)$ & - & 59 \\
\hline Trichinellosis & 9 & $(0.01)$ & 4 & $(0.00)$ & - & 13 \\
\hline Tuberculosis & 5,840 & $(3.72)$ & 3,578 & $(2.21)$ & 3 & 9,421 \\
\hline Tularemia & 113 & $(0.07)$ & 67 & $(0.04)$ & - & 180 \\
\hline Typhoid fever & 183 & $(0.12)$ & 165 & $(0.10)$ & 1 & 349 \\
\hline Vancomycin-intermediate Staphylococcus aureus (VISA) & 111 & $(0.09)$ & 101 & $(0.08)$ & - & 212 \\
\hline Vibriosis & 862 & $(0.59)$ & 393 & $(0.26)$ & 6 & 1,261 \\
\hline Viral hemorrhagic fevers & 3 & $(0.00)$ & 2 & $(0.00)$ & - & 5 \\
\hline Yellow fever ${ }^{\dagger}$ & - & $(0.00)$ & - & $(0.00)$ & - & - \\
\hline
\end{tabular}

\footnotetext{
* No cases of anthrax; dengue hemorrhagic fever (and dengue shock syndrome), eastern equine encephalitis, nonneuroinvasive disease; poliomyelitis, paralytic poliovirus infection, nonparalytic; severe acute respiratory syndrome-associated Coronavirus disease (SARS-CoV); smallpox; vancomycin-resistant Staphylococcus aureus (VRSA); western equine encephalitis, neuroinvasive and nonneuroinvasive disease; or yellow fever were reported in the United States during 2014.

† Totals reported to the Division of Vector-Borne Diseases, National Center for Emerging and Zoonotic Infectious Diseases (ArboNET Surveillance), as of July 15, 2015.

$\S$ Totals reported to the Division of STD Prevention, National Center for HIV/AIDS, Viral Hepatitis, STD, and TB Prevention (NCHHSTP), as of June 10, 2015.

१ Reportable in $<25$ states.

** Total number of HIV diagnoses reported to the Division of HIV/AIDS Prevention, NCHHSTP through December 31, 2014.

t† Totals reported to the Division of Influenza, National Center for Immunization and Respiratory Diseases, as of June 30, 2015.

$\S \S$ Includes the following categories: primary, secondary, latent (including early latent, late latent, and latent syphilis of unknown duration), neurosyphilis, late (including late syphilis with clinical manifestations other than neurosyphilis), and congenital syphilis. Totals reported to the Division of STD Prevention, NCHHSTP, as of June 10, 2015.

กๆ Totals reported to the Division of Tuberculosis Elimination, NCHHSTP, as of June 15, 2015.
} 
TABLE 5. Number of reported cases of notifiable diseases* and rates per 100,000, by race, excluding U.S. territories — United States, 2014

\begin{tabular}{|c|c|c|c|c|c|c|c|c|c|c|c|}
\hline \multirow[b]{2}{*}{ Disease } & \multicolumn{2}{|c|}{$\begin{array}{l}\text { American Indian } \\
\text { or Alaska Native } \\
\end{array}$} & \multicolumn{2}{|c|}{$\begin{array}{c}\text { Asian or } \\
\text { Pacific Islander }\end{array}$} & \multicolumn{2}{|c|}{ Black } & \multicolumn{2}{|c|}{ White } & \multirow{2}{*}{$\begin{array}{c}\begin{array}{c}\text { Other } \\
\text { Race }\end{array} \\
\text { No. }\end{array}$} & \multirow{2}{*}{$\begin{array}{c}\begin{array}{c}\text { Race not } \\
\text { stated }\end{array} \\
\text { No. }\end{array}$} & \multirow[b]{2}{*}{ Total } \\
\hline & No. & Rate & No. & Rate & No. & Rate & No. & Rate & & & \\
\hline \multicolumn{12}{|l|}{ Arboviral diseases $^{\dagger}$} \\
\hline \multicolumn{12}{|l|}{ California serogroup viruses } \\
\hline \multicolumn{12}{|l|}{ West Nile virus } \\
\hline neuroinvasive & 7 & $(0.15)$ & 17 & $(0.09)$ & 78 & $(0.18)$ & 806 & $(0.32)$ & 114 & 325 & 1,347 \\
\hline nonneuroinvasive & 5 & $(0.11)$ & 10 & $(0.05)$ & 21 & $(0.05)$ & 571 & $(0.23)$ & 39 & 212 & 858 \\
\hline Babesiosis, total & 6 & $(0.20)$ & 51 & $(0.35)$ & 31 & $(0.12)$ & 1,021 & $(0.62)$ & 30 & 621 & 1,760 \\
\hline confirmed & 5 & $(0.17)$ & 48 & $(0.32)$ & 28 & $(0.10)$ & 841 & $(0.51)$ & 28 & 522 & 1,472 \\
\hline probable & 1 & $(0.03)$ & 3 & $(0.02)$ & 3 & $(0.01)$ & 180 & $(0.11)$ & 2 & 99 & 288 \\
\hline Botulism, total & 5 & $(0.11)$ & 9 & $(0.05)$ & 5 & $(0.01)$ & 108 & $(0.04)$ & 2 & 32 & 161 \\
\hline infant & 1 & $(1.28)$ & 8 & (3.23) & 3 & $(0.44)$ & 91 & (3.09) & 1 & 23 & 127 \\
\hline Brucellosis & - & $(0.00)$ & 2 & $(0.01)$ & 4 & $(0.01)$ & 54 & $(0.02)$ & 13 & 19 & 92 \\
\hline Chlamydia trachomatis, infection ${ }^{\S}$ & 18,205 & $(402.86)$ & 21,794 & $(112.35)$ & 436,045 & $(984.09)$ & 477,720 & $(190.61)$ & 62,704 & 425,321 & $1,441,789$ \\
\hline Coccidioidomycosis" & 127 & $(5.68)$ & 139 & (1.48) & 229 & (1.69) & 2,024 & $(2.03)$ & 260 & 5,453 & 8,232 \\
\hline Cryptosporidiosis, total & 80 & $(1.77)$ & 96 & $(0.49)$ & 826 & $(1.86)$ & 5,919 & $(2.36)$ & 309 & 1,452 & 8,682 \\
\hline confirmed & 48 & (1.06) & 59 & $(0.30)$ & 530 & $(1.20)$ & 3,676 & $(1.47)$ & 203 & 1,049 & 5,565 \\
\hline probable & 32 & $(0.71)$ & 37 & $(0.19)$ & 296 & $(0.67)$ & 2,243 & $(0.89)$ & 106 & 403 & 3,117 \\
\hline Cyclosporiasis & 1 & $(0.03)$ & 7 & $(0.04)$ & 16 & $(0.04)$ & 292 & $(0.13)$ & 5 & 77 & 398 \\
\hline Dengue fever ${ }^{\dagger}$ & 3 & $(0.07)$ & 67 & $(0.34)$ & 36 & $(0.06)$ & 345 & $(0.14)$ & 35 & 203 & 680 \\
\hline \multicolumn{12}{|l|}{ Ehrlichiosis/Anaplasmosis } \\
\hline Anaplasma phagocytophilum & 30 & $(0.75)$ & 17 & $(0.09)$ & 21 & $(0.05)$ & 1,928 & $(0.81)$ & 47 & 757 & 2,800 \\
\hline Ehrlichia chaffeensis & 12 & $(0.30)$ & 12 & $(0.07)$ & 40 & $(0.09)$ & 971 & $(0.41)$ & 21 & 419 & 1,475 \\
\hline undetermined & 3 & $(0.07)$ & 1 & $(0.01)$ & 2 & $(0.00)$ & 136 & $(0.06)$ & 18 & 36 & 196 \\
\hline Giardiasis & 79 & $(2.26)$ & 670 & $(4.01)$ & 1,161 & $(3.46)$ & 6,718 & (3.40) & 652 & 5,274 & 14,554 \\
\hline Gonorrhea ${ }^{\S}$ & 4,404 & (97.46) & 3,761 & (19.39) & 157,302 & $(355.01)$ & 99,200 & (39.58) & 12,939 & 72,456 & 350,062 \\
\hline \multicolumn{12}{|l|}{ Haemophilus influenzae, invasive disease } \\
\hline $\begin{array}{l}\text { all ages, serotypes } \\
\text { age }<5 \text { yrs }\end{array}$ & 42 & $(0.93)$ & 68 & $(0.35)$ & 414 & $(0.93)$ & 2,295 & $(0.92)$ & 91 & 631 & 3,541 \\
\hline serotype b & 2 & $(0.52)$ & 1 & $(0.08)$ & - & $(0.00)$ & 30 & $(0.20)$ & - & 7 & 40 \\
\hline nontypeable & 6 & (1.55) & 2 & $(0.16)$ & 27 & $(0.80)$ & 67 & $(0.45)$ & 8 & 18 & 128 \\
\hline non-b serotype & - & $(0.00)$ & 1 & $(0.08)$ & 10 & $(0.29)$ & 18 & $(0.12)$ & 2 & 7 & 38 \\
\hline unknown serotype & 10 & $(2.59)$ & 12 & $(0.96)$ & 58 & $(1.71)$ & 116 & $(0.78)$ & 15 & 55 & 266 \\
\hline Hansen's disease & 1 & $(0.03)$ & 24 & $(0.13)$ & 3 & $(0.01)$ & 36 & $(0.02)$ & 3 & 21 & 88 \\
\hline Hantavirus pulmonary syndrome & 7 & $(0.16)$ & 1 & $(0.01)$ & - & $(0.00)$ & 20 & $(0.01)$ & - & 4 & 32 \\
\hline A acute & 4 & $(0.09)$ & 137 & $(0.71)$ & 85 & $(0.19)$ & 710 & $(0.28)$ & 57 & 246 & 1,239 \\
\hline B acute & 23 & $(0.51)$ & 55 & $(0.28)$ & 345 & $(0.79)$ & 1,817 & $(0.73)$ & 61 & 490 & 2,791 \\
\hline B chronic & 24 & $(0.60)$ & 2,780 & (16.36) & 1,555 & $(4.55)$ & 1,801 & $(0.88)$ & 492 & 5,748 & 12,400 \\
\hline B infection perinatal & - & $(0.00)$ & 21 & $(0.11)$ & 6 & $(0.01)$ & 8 & $(0.00)$ & 1 & 11 & 47 \\
\hline Cacute & 29 & $(0.74)$ & 11 & $(0.06)$ & 78 & $(0.19)$ & 1,655 & $(0.70)$ & 62 & 369 & 2,204 \\
\hline C past or present & 1,331 & $(38.26)$ & 1,189 & (7.13) & 12,128 & $(35.10)$ & 55,561 & $(28.76)$ & 5,970 & 86,684 & 162,863 \\
\hline $\begin{array}{l}\text { Human immunodeficiency virus (HIV) } \\
\text { diagnoses** }\end{array}$ & 205 & $(8.70)$ & 813 & $(4.80)$ & 15,843 & $(40.10)$ & 10,116 & $(5.10)$ & 8,629 & - & 35,606 \\
\hline $\begin{array}{l}\text { Influenza-associated pediatric mortality }{ }^{\dagger \dagger} \\
\text { Invasive pneumococcal disease }\end{array}$ & 2 & $(0.17)$ & 6 & $(0.14)$ & 20 & $(0.17)$ & 95 & $(0.19)$ & 1 & 17 & 141 \\
\hline all ages & 216 & (7.99) & 185 & $(1.75)$ & 2,294 & $(6.75)$ & 9,054 & $(5.28)$ & 382 & 3,225 & 15,356 \\
\hline age $<5$ yrs & 19 & $(7.02)$ & 42 & $(5.42)$ & 224 & $(7.92)$ & 466 & $(4.22)$ & 42 & 272 & 1,065 \\
\hline Legionellosis & 21 & $(0.46)$ & 69 & $(0.36)$ & 901 & $(2.03)$ & 3,155 & $(1.26)$ & 122 & 898 & 5,166 \\
\hline Leptospirosis & - & $(0.00)$ & 2 & $(0.01)$ & 1 & $(0.00)$ & 9 & $(0.00)$ & 4 & 22 & 38 \\
\hline Listeriosis & 8 & $(0.18)$ & 70 & $(0.36)$ & 66 & $(0.15)$ & 498 & $(0.20)$ & 25 & 102 & 769 \\
\hline Lyme disease, total & 102 & $(2.26)$ & 376 & $(2.04)$ & 349 & $(0.79)$ & 19,745 & (7.89) & 987 & 11,902 & 33,461 \\
\hline confirmed & 74 & (1.64) & 259 & $(1.40)$ & 255 & $(0.58)$ & 14,791 & $(5.91)$ & 804 & 9,176 & 25,359 \\
\hline probable & 28 & $(0.62)$ & 117 & $(0.63)$ & 94 & $(0.21)$ & 4,954 & (1.98) & 183 & 2,726 & 8,102 \\
\hline Malaria & 3 & $(0.07)$ & 103 & $(0.53)$ & 823 & $(1.86)$ & 261 & $(0.10)$ & 56 & 407 & 1,653 \\
\hline Measles, total & 4 & (0.09) & 86 & $(0.44)$ & 2 & $(0.00)$ & 509 & $(0.20)$ & 4 & 62 & 667 \\
\hline indigenous & 4 & $(0.09)$ & 58 & $(0.30)$ & 1 & $(0.00)$ & 484 & $(0.19)$ & 3 & 54 & 604 \\
\hline imported & - & $(0.00)$ & 28 & $(0.14)$ & 1 & $(0.00)$ & 25 & $(0.01)$ & 1 & 8 & 63 \\
\hline Meningococcal disease & & & & & & & & & & & \\
\hline all serogroups & 7 & $(0.15)$ & 9 & $(0.05)$ & 53 & $(0.12)$ & 296 & $(0.12)$ & 10 & 58 & 433 \\
\hline serogroups ACY and W-135 & 5 & $(0.11)$ & - & $(0.00)$ & 13 & $(0.03)$ & 86 & $(0.03)$ & 3 & 16 & 123 \\
\hline serogroup B & 1 & $(0.02)$ & 1 & $(0.01)$ & 12 & $(0.03)$ & 64 & $(0.03)$ & 1 & 10 & 89 \\
\hline other serogroups & - & $(0.00)$ & 2 & $(0.01)$ & 5 & $(0.01)$ & 15 & $(0.01)$ & - & 3 & 25 \\
\hline unknown serogroup & 1 & $(0.02)$ & 6 & $(0.03)$ & 23 & $(0.05)$ & 131 & $(0.05)$ & 6 & 29 & 196 \\
\hline
\end{tabular}

See table footnotes on next page. 
Morbidity and Mortality Weekly Report

TABLE 5. (Continued) Number of reported cases of notifiable diseases* and rates per 100,000, by race, excluding U.S. territories - United States, 2014

\begin{tabular}{|c|c|c|c|c|c|c|c|c|c|c|c|}
\hline \multirow[b]{2}{*}{ Disease } & \multicolumn{2}{|c|}{$\begin{array}{l}\text { American Indian } \\
\text { or Alaska Native } \\
\end{array}$} & \multicolumn{2}{|c|}{$\begin{array}{c}\text { Asian or } \\
\text { Pacific Islander } \\
\end{array}$} & \multicolumn{2}{|c|}{ Black } & \multicolumn{2}{|c|}{ White } & \multirow{2}{*}{$\begin{array}{c}\begin{array}{c}\text { Other } \\
\text { Race }\end{array} \\
\text { No. }\end{array}$} & \multirow{2}{*}{$\begin{array}{c}\begin{array}{c}\text { Race not } \\
\text { stated }\end{array} \\
\text { No. }\end{array}$} & \multirow[b]{2}{*}{ Total } \\
\hline & No. & Rate & No. & Rate & No. & Rate & No. & Rate & & & \\
\hline Mumps & 4 & $(0.09)$ & 39 & $(0.20)$ & 104 & $(0.23)$ & 781 & $(0.31)$ & 24 & 271 & 1,223 \\
\hline Pertussis & 211 & $(4.67)$ & 560 & $(2.89)$ & 1,460 & (3.30) & 23,466 & (9.36) & 1,074 & 6,200 & 32,971 \\
\hline Q fever, total & 3 & $(0.07)$ & 7 & $(0.04)$ & 8 & $(0.02)$ & 112 & $(0.05)$ & 9 & 29 & 168 \\
\hline acute & 3 & $(0.07)$ & 6 & $(0.03)$ & 7 & $(0.02)$ & 92 & $(0.04)$ & 6 & 18 & 132 \\
\hline chronic & - & $(0.00)$ & 1 & $(0.01)$ & 1 & $(0.00)$ & 20 & $(0.01)$ & 3 & 11 & 36 \\
\hline Salmonellosis & 401 & (8.87) & 1,829 & (9.43) & 4,522 & $(10.21)$ & 32,194 & (12.85) & 2,099 & 10,410 & 51,455 \\
\hline Shiga toxin-producing E. coli (STEC) & 56 & $(1.24)$ & 145 & $(0.75)$ & 244 & $(0.55)$ & 4,256 & $(1.70)$ & 210 & 1,268 & 6,179 \\
\hline Shigellosis & 684 & (15.14) & 280 & (1.44) & 5,511 & (12.44) & 10,049 & $(4.01)$ & 885 & 3,336 & 20,745 \\
\hline Spotted fever rickettsiosis, total & 53 & $(1.21)$ & 22 & $(0.11)$ & 95 & $(0.21)$ & 2,597 & $(1.04)$ & 35 & 955 & 3,757 \\
\hline confirmed & 1 & $(0.02)$ & 1 & $(0.01)$ & 4 & $(0.01)$ & 77 & $(0.03)$ & 1 & 31 & 115 \\
\hline probable & 52 & (1.18) & 21 & $(0.11)$ & 90 & $(0.20)$ & 2,515 & $(1.01)$ & 34 & 922 & 3,634 \\
\hline Streptococcal toxic shock syndrome & 1 & $(0.04)$ & 5 & $(0.05)$ & 36 & $(0.11)$ & 162 & $(0.10)$ & 14 & 41 & 259 \\
\hline Syphilis, total, all stages $\$, \S \S$ & 436 & $(9.65)$ & 1,576 & $(8.12)$ & 24,281 & $(54.80)$ & 28,144 & (11.23) & 4,122 & 4,891 & 63,450 \\
\hline primary and secondary ${ }^{\S}$ & 187 & $(4.14)$ & 483 & $(2.49)$ & 7,381 & (16.66) & 9,682 & $(3.86)$ & 1,083 & 1,183 & 19,999 \\
\hline congenital ${ }^{\S}$ & 5 & $(6.42)$ & 18 & $(7.27)$ & 227 & (33.45) & 175 & $(5.94)$ & 17 & 16 & 458 \\
\hline Tetanus & - & $(0.00)$ & 1 & $(0.01)$ & - & $(0.00)$ & 17 & $(0.01)$ & - & 7 & 25 \\
\hline $\begin{array}{l}\text { Toxic shock syndrome (other than } \\
\text { streptococcal) }\end{array}$ & - & $(0.00)$ & 3 & $(0.02)$ & 5 & $(0.02)$ & 45 & $(0.02)$ & - & 6 & 59 \\
\hline Tuberculosis"1ีी & 131 & $(2.90)$ & 3,006 & (15.50) & 2,078 & (4.69) & 3,864 & (1.54) & 254 & 88 & 9,421 \\
\hline Tularemia & 9 & $(0.20)$ & - & $(0.00)$ & 1 & $(0.00)$ & 143 & $(0.06)$ & 1 & 26 & 180 \\
\hline Typhoid fever & 2 & $(0.04)$ & 200 & (1.03) & 18 & $(0.04)$ & 50 & $(0.02)$ & 31 & 48 & 349 \\
\hline $\begin{array}{l}\text { Vancomycin-intermediate } \\
\text { Staphylococcus aureus (VISA) }\end{array}$ & 1 & $(0.03)$ & 1 & $(0.01)$ & 51 & $(0.13)$ & 121 & $(0.06)$ & - & 38 & 212 \\
\hline Vibriosis & 6 & $(0.14)$ & 51 & $(0.27)$ & 55 & $(0.13)$ & 860 & $(0.37)$ & 30 & 259 & 1,261 \\
\hline Yellow fever ${ }^{\dagger}$ & - & $(0.00)$ & - & $(0.00)$ & - & $(0.00)$ & - & $(0.00)$ & - & - & - \\
\hline
\end{tabular}

* Conditions for which <25 cases were reported for the year are not included in the table. No cases of anthrax; dengue hemorrhagic fever (and dengue shock syndrome), eastern equine encephalitis, nonneuroinvasive disease; poliomyelitis, paralytic; poliovirus infection, nonparalytic; severe acute respiratory syndrome-associated Coronavirus disease (SARS-CoV); smallpox; vancomycin-resistant Staphylococcus aureus (VRSA); western equine encephalitis, neuroinvasive and nonneuroinvasive disease; or yellow fever were reported in the United States during 2014.

† Totals reported to the Division of Vector-Borne Diseases, National Center for Emerging and Zoonotic Infectious Diseases (ArboNET Surveillance), as of June 1, 2014.

$\S$ Totals reported to the Division of STD Prevention, National Center for HIV/AIDS, Viral Hepatitis, STD, and TB Prevention (NCHHSTP), as of June 10, 2015.

I Reportable in $<25$ states.

** Total number of HIV diagnoses reported to the Division of HIV/AIDS Prevention, National Center for HIV/AIDS, Viral Hepatitis, STD, and TB Prevention (NCHHSTP) through December 31, 2014.

t+ Totals reported to the Division of Influenza, National Center for Immunization and Respiratory Diseases, as of June 30, 2015.

$\S \S$ Includes the following categories: primary, secondary, latent (including early latent, late latent, and latent syphilis of unknown duration), neurosyphilis, late (including late syphilis with clinical manifestations other than neurosyphilis), and congenital syphilis. Totals reported to the Division of STD Prevention, NCHHSTP, as of June 10, 2015.

१ฯ Totals reported to the Division of Tuberculosis Elimination, NCHHSTP, as of July 15, 2015. 
TABLE 6. Number of reported cases of notifiable diseases* and rates per 100,000 population, by ethnicity, excluding U.S. territories United States, 2014

\begin{tabular}{|c|c|c|c|c|c|c|}
\hline \multirow[b]{2}{*}{ Disease } & \multicolumn{2}{|c|}{ Hispanic } & \multicolumn{2}{|c|}{ Non-Hispanic } & \multicolumn{2}{|c|}{ Ethnicity not stated } \\
\hline & No. & Rate & No. & Rate & No. & Total \\
\hline \multicolumn{7}{|l|}{ Arboviral diseases $^{\dagger}$} \\
\hline \multicolumn{7}{|l|}{ California serogroup viruses } \\
\hline neuroinvasive & 2 & $(0.00)$ & 69 & $(0.03)$ & 14 & 85 \\
\hline \multicolumn{7}{|l|}{ West Nile virus } \\
\hline neuroinvasive & 251 & $(0.45)$ & 713 & $(0.27)$ & 383 & 1,347 \\
\hline nonneuroinvasive & 75 & $(0.14)$ & 520 & $(0.20)$ & 263 & 858 \\
\hline Babesiosis, total & 76 & $(0.18)$ & 842 & $(0.51)$ & 842 & 1,760 \\
\hline confirmed & 68 & $(0.17)$ & 692 & $(0.41)$ & 712 & 1,472 \\
\hline probable & 8 & $(0.02)$ & 150 & $(0.09)$ & 130 & 288 \\
\hline Botulism, total & 38 & $(0.07)$ & 86 & $(0.03)$ & 37 & 161 \\
\hline infant & 31 & (3.06) & 69 & $(2.35)$ & 27 & 127 \\
\hline Brucellosis & 49 & $(0.09)$ & 31 & $(0.01)$ & 12 & 92 \\
\hline Chlamydia trachomatis, infection $\S$ & 201,171 & $(363.21)$ & 711,693 & $(270.12)$ & 528,925 & $1,441,789$ \\
\hline Coccidioidomycosis" & 936 & $(1.69)$ & 1,737 & $(0.66)$ & 5,559 & 8,232 \\
\hline Cryptosporidiosis, total & 631 & (1.14) & 5,789 & $(2.20)$ & 2,262 & 8,682 \\
\hline confirmed & 434 & $(0.78)$ & 3,617 & $(1.37)$ & 1,514 & 5,565 \\
\hline probable & 197 & $(0.36)$ & 2,172 & $(0.82)$ & 748 & 3,117 \\
\hline Cyclosporiasis & 60 & $(0.11)$ & 252 & $(0.10)$ & 86 & 398 \\
\hline Dengue fever ${ }^{\dagger}$ & 272 & $(0.49)$ & 248 & $(0.09)$ & 160 & 680 \\
\hline \multicolumn{7}{|l|}{ Ehrlichiosis/Anaplasmosis } \\
\hline Anaplasma phagocytophilum & 31 & $(0.06)$ & 1,705 & $(0.68)$ & 1,064 & 2,800 \\
\hline Ehrlichia chaffeensis & 21 & $(0.04)$ & 1,044 & $(0.41)$ & 410 & 1,475 \\
\hline undetermined & 2 & $(0.00)$ & 150 & $(0.06)$ & 44 & 196 \\
\hline Giardiasis & 1,151 & $(2.81)$ & 7,347 & (3.49) & 6,056 & 14,554 \\
\hline Gonorrhea§ & 38,672 & $(69.82)$ & 210,362 & $(79.84)$ & 101,028 & 350,062 \\
\hline \multicolumn{7}{|l|}{ Haemophilus influenzae, invasive disease } \\
\hline all ages, serotypes & 216 & $(0.39)$ & 2,148 & $(0.82)$ & 1,177 & 3,541 \\
\hline \multicolumn{7}{|l|}{ age $<5$ yrs } \\
\hline serotype b & 5 & $(0.10)$ & 23 & $(0.16)$ & 12 & 40 \\
\hline nontypeable & 24 & $(0.47)$ & 66 & $(0.45)$ & 38 & 128 \\
\hline non-b serotype & 5 & $(0.10)$ & 27 & $(0.18)$ & 6 & 38 \\
\hline unknown serotype & 43 & $(0.84)$ & 139 & $(0.94)$ & 84 & 266 \\
\hline Hansen's disease & 12 & $(0.02)$ & 48 & $(0.02)$ & 28 & 88 \\
\hline Hantavirus pulmonary syndrome & 4 & $(0.01)$ & 21 & $(0.01)$ & 7 & 32 \\
\hline Hemolytic uremic syndrome postdiarrheal & 25 & $(0.05)$ & 178 & $(0.07)$ & 47 & 250 \\
\hline \multicolumn{7}{|l|}{ Hepatitis, virus } \\
\hline A acute & 211 & $(0.38)$ & 730 & $(0.28)$ & 298 & 1,239 \\
\hline B acute & 158 & $(0.29)$ & 1,883 & $(0.72)$ & 750 & 2,791 \\
\hline B chronic & 319 & $(0.76)$ & 4,605 & $(2.11)$ & 7,476 & 12,400 \\
\hline B infection perinatal & 2 & $(0.00)$ & 34 & $(0.01)$ & 11 & 47 \\
\hline Cacute & 127 & $(0.24)$ & 1,421 & $(0.57)$ & 656 & 2,204 \\
\hline C past or present & 5,086 & $(12.79)$ & 44,360 & $(21.32)$ & 113,417 & 162,863 \\
\hline Human immunodeficiency virus (HIV) diagnoses** & 7,927 & (14.30) & 27,679 & (10.50) & - & 35,606 \\
\hline Influenza-associated pediatric mortality ${ }^{\dagger+}$ & 44 & $(0.25)$ & 84 & $(0.15)$ & 13 & 141 \\
\hline \multicolumn{7}{|l|}{ Invasive pneumococcal disease } \\
\hline all ages & 1,005 & (2.94) & 8,503 & $(4.61)$ & 5,848 & 15,356 \\
\hline age $<5$ yrs & 153 & $(4.50)$ & 572 & $(4.97)$ & 340 & 1,065 \\
\hline Legionellosis & 280 & $(0.51)$ & 3,577 & $(1.36)$ & 1,309 & 5,166 \\
\hline Leptospirosis & 1 & $(0.00)$ & 16 & $(0.01)$ & 21 & 38 \\
\hline Listeriosis & 117 & $(0.21)$ & 498 & $(0.19)$ & 154 & 769 \\
\hline Lyme disease, total & 650 & $(1.18)$ & 13,839 & $(5.28)$ & 18,972 & 33,461 \\
\hline confirmed & 469 & $(0.85)$ & 10,244 & $(3.91)$ & 14,646 & 25,359 \\
\hline probable & 181 & $(0.33)$ & 3,595 & $(1.37)$ & 4,326 & 8,102 \\
\hline Malaria & 33 & $(0.06)$ & 1,264 & $(0.48)$ & 356 & 1,653 \\
\hline Measles, total & 38 & $(0.07)$ & 534 & $(0.20)$ & 95 & 667 \\
\hline indigenous & 38 & $(0.07)$ & 479 & $(0.18)$ & 87 & 604 \\
\hline Imported & 0 & $(0.00)$ & 55 & $(0.02)$ & 8 & 63 \\
\hline \multicolumn{7}{|l|}{ Meningococcal disease } \\
\hline all serogroups & 69 & $(0.12)$ & 278 & $(0.11)$ & 86 & 433 \\
\hline serogroups ACWY & 21 & $(0.04)$ & 76 & $(0.03)$ & 26 & 123 \\
\hline serogroup $B$ & 2 & $(0.00)$ & 58 & $(0.02)$ & 29 & 89 \\
\hline other serogroups & 1 & $(0.00)$ & 19 & $(0.01)$ & 5 & 25 \\
\hline unknown serogroup & 45 & $(0.08)$ & 125 & $(0.05)$ & 26 & 196 \\
\hline
\end{tabular}

See table footnotes on next page. 
TABLE 6. (Continued) Number of reported cases of notifiable diseases* and rates per 100,000 population, by ethnicity, excluding U.S. territories United States, 2014

\begin{tabular}{|c|c|c|c|c|c|c|}
\hline \multirow[b]{2}{*}{ Disease } & \multicolumn{2}{|c|}{ Hispanic } & \multicolumn{2}{|c|}{ Non-Hispanic } & \multicolumn{2}{|c|}{ Ethnicity not stated } \\
\hline & No. & Rate & No. & Rate & No. & Total \\
\hline Mumps & 66 & $(0.12)$ & 859 & $(0.33)$ & 298 & 1,223 \\
\hline Pertussis & 6,799 & $(12.28)$ & 19,531 & (7.41) & 6,641 & 32,971 \\
\hline Q fever, total & 22 & $(0.04)$ & 111 & $(0.04)$ & 35 & 168 \\
\hline acute & 20 & $(0.04)$ & 90 & $(0.03)$ & 22 & 132 \\
\hline chronic & 2 & $(0.00)$ & 21 & $(0.01)$ & 13 & 36 \\
\hline Salmonellosis & 7,181 & (12.97) & 29,707 & $(11.28)$ & 14,567 & 51,455 \\
\hline Shiga toxin-producing E. coli (STEC) & 776 & $(1.40)$ & 3,903 & $(1.48)$ & 1,500 & 6,179 \\
\hline Shigellosis & 4,091 & (7.39) & 11,989 & $(4.55)$ & 4,665 & 20,745 \\
\hline Spotted fever rickettsiosis, total & 124 & $(0.22)$ & 2,494 & $(0.94)$ & 1,139 & 3,757 \\
\hline confirmed & 6 & $(0.01)$ & 73 & $(0.03)$ & 36 & 115 \\
\hline probable & 118 & $(0.21)$ & 2,415 & $(0.91)$ & 1,101 & 3,634 \\
\hline Streptococcal toxic shock syndrome & 26 & $(0.11)$ & 150 & $(0.08)$ & 83 & 259 \\
\hline Syphilis, total, all stages ${ }^{\S, \S \S}$ & 15,348 & $(27.71)$ & 43,029 & $(16.33)$ & 5,073 & 63,450 \\
\hline primary and secondary ${ }^{\S}$ & 4,036 & $(7.29)$ & 14,700 & $(5.58)$ & 1,263 & 19,999 \\
\hline congenital $^{\S}$ & 110 & $(10.86)$ & 322 & $(10.97)$ & 26 & 458 \\
\hline Tetanus & 4 & $(0.01)$ & 12 & $(0.00)$ & 9 & 25 \\
\hline Toxic shock syndrome (other than streptococcal) & 3 & $(0.01)$ & 41 & $(0.02)$ & 15 & 59 \\
\hline Tuberculosis & 2,758 & (4.98) & 6,653 & $(2.53)$ & 10 & 9,421 \\
\hline Tularemia & 7 & $(0.01)$ & 148 & $(0.06)$ & 25 & 180 \\
\hline Typhoid fever & 28 & $(0.05)$ & 271 & $(0.10)$ & 50 & 349 \\
\hline Vancomycin-intermediate Staphylococcus aureus (VISA) & 13 & $(0.04)$ & 145 & $(0.07)$ & 54 & 212 \\
\hline Vibriosis & 142 & $(0.27)$ & 802 & $(0.33)$ & 317 & 1,261 \\
\hline Yellow fever ${ }^{\dagger}$ & - & $(0.00)$ & - & $(0.00)$ & - & - \\
\hline
\end{tabular}

* Conditions for which $<25$ cases were reported for the year are not included in the table. No cases of anthrax; dengue hemorrhagic fever (and dengue shock syndrome), eastern equine encephalitis, nonneuroinvasive disease; poliomyelitis, paralytic; poliovirus infection, nonparalytic; severe acute respiratory syndromeassociated Coronavirus disease (SARS-CoV); smallpox; vancomycin-resistant Staphylococcus aureus (VRSA); western equine encephalitis, neuroinvasive and nonneuroinvasive disease; or yellow fever were reported in the United States during 2014.

† Totals reported to the Division of Vector-Borne Diseases, National Center for Emerging and Zoonotic Infectious Diseases (ArboNET Surveillance), as of July 1, 2015.

$\S$ Totals reported to the Division of STD Prevention, National Center for HIV/AIDS, Viral Hepatitis, STD, and TB Prevention (NCHHSTP), as of June 10, 2015.

I Reportable in $<25$ states.

** Total number of HIV diagnoses reported to the Division of HIV/AIDS Prevention, National Center for HIV/AIDS, Viral Hepatitis, STD, and TB Prevention (NCHHSTP) through December 31, 2014.

t† Totals reported to the Division of Influenza, National Center for Immunization and Respiratory Diseases, as of June 30, 2015.

$\S \S$ Includes the following categories: primary, secondary, latent (including early latent, late latent, and latent syphilis of unknown duration), neurosyphilis, late (including late syphilis with clinical manifestations other than neurosyphilis), and congenital syphilis. Totals reported to the Division of STD Prevention, NCHHSTP, as of June 10, 2015.

ๆๆ Totals reported to the Division of Tuberculosis Elimination, NCHHSTP, as of July 15, 2015. 
TABLE 7. Rate of notifiable diseases, ${ }^{*}$ excluding U.S. territories, by year — United States, 2004-2014

\begin{tabular}{|c|c|c|c|c|c|c|c|c|c|c|c|}
\hline Disease & 2004 & 2005 & 2006 & 2007 & 2008 & 2009 & 2010 & 2011 & 2012 & 2013 & $2014^{*}$ \\
\hline AIDS & 15.28 & 14 & 12.87 & 12.53 & 13 & + & + & + & + & + & + \\
\hline Anthrax & - & - & 0 & 0 & 0 & 0 & 0 & 0 & 0 & 0 & 0 \\
\hline \multicolumn{12}{|l|}{ Arboviral diseases ${ }^{\S}$} \\
\hline \multicolumn{12}{|l|}{ California serogroup virus disease } \\
\hline neuroinvasive & - & 0.02 & 0.02 & 0.02 & 0.02 & 0.02 & 0.02 & 0.04 & 0.02 & 0.03 & 0.03 \\
\hline nonneuroinvasive & १ & 0 & 0 & 0 & 0 & 0 & 0 & 0.01 & 0 & 0.01 & 0 \\
\hline \multicolumn{12}{|c|}{ Eastern equine encephalitis virus disease } \\
\hline neuroinvasive & - & 0 & 0 & 0 & 0 & 0 & 0 & 0 & 0 & 0 & 0 \\
\hline nonneuroinvasive & १ & 0 & 0 & 0 & 0 & 0 & - & - & - & - & - \\
\hline \multicolumn{12}{|l|}{ Powassan virus disease } \\
\hline neuroinvasive & - & 0 & 0 & 0 & 0 & 0 & 0 & 0 & 0 & 0 & 0 \\
\hline nonneuroinvasive & १ & 0 & 0 & 0 & 0 & - & - & 0 & 0 & 0 & 0 \\
\hline \multicolumn{12}{|l|}{ St. Louis encephalitis virus disease } \\
\hline neuroinvasive & - & 0 & 0 & 0 & 0 & 0 & 0 & 0 & 0 & 0 & 0 \\
\hline nonneuroinvasive & १ & 0 & 0 & 0 & 0 & 0 & 0 & 0 & 0 & 0 & 0 \\
\hline \multicolumn{12}{|l|}{ West Nile virus disease } \\
\hline neuroinvasive & - & 0.45 & 0.5 & 0.41 & 0.23 & 0.13 & 0.2 & 0.16 & 0.92 & 0.4 & 0.42 \\
\hline nonneuroinvasive & १ & 0.58 & 0.94 & 0.8 & 0.22 & 0.11 & 0.13 & 0.07 & 0.9 & 0.38 & 0.27 \\
\hline \multicolumn{12}{|c|}{ Western equine encephalitis virus disease } \\
\hline neuroinvasive & - & - & - & - & - & - & - & - & - & - & - \\
\hline nonneuroinvasive & १ & - & - & - & - & - & - & - & - & - & - \\
\hline \multicolumn{12}{|l|}{ Babesiosis, total** } \\
\hline confirmed & १ & १ & १ & १ & ๆ & १ & १ & १ & 0.22 & 0.77 & 0.71 \\
\hline probable & १ & १ & १ & ก & १ & १ & ๆ & १ & 0.06 & 0.16 & 0.14 \\
\hline $\begin{array}{l}\text { Botulism, total } \\
\text { foodborne }\end{array}$ & 0.02 & 0.01 & 0.02 & 0.05 & 0.05 & 0.04 & 0.04 & 0.01 & 0.05 & 0.05 & 0.05 \\
\hline foodborne & 0.01 & 0.01 & 0.01 & 0.01 & 0.01 & 0 & 0 & 0.01 & 0.01 & 0 & 0 \\
\hline infant & 2.12 & 2.09 & 2.35 & 2.05 & 2.56 & 1.92 & 1.88 & 2.34 & 3.1 & 3.45 & 3.22 \\
\hline other (wound and unspecified) & - & - & - & - & - & - & - & - & 0.01 & 0 & 0.01 \\
\hline Brucellosis & 0.04 & 0.04 & 0.04 & 0.04 & 0.03 & 0.04 & 0.04 & 0.03 & 0.04 & 0.03 & 0.03 \\
\hline Chancroid $^{\dagger \dagger}$ & 0 & 0.01 & 0.01 & 0.01 & 0.01 & 0.01 & 0.01 & 0 & 0 & 0 & 0 \\
\hline Chlamydia trachomatis infections ${ }^{\dagger \dagger}$ & 319.61 & 332.51 & 347.8 & 370.2 & 401.34 & 409.19 & 426.01 & 457.14 & 456.69 & 446.65 & 452.17 \\
\hline Cholera & 0 & 0 & 0 & 0 & 0 & 0 & 0 & 0.01 & 0.01 & 0 & 0 \\
\hline Coccidioidomycosis $§ \S$ & 4.14 & 6.24 & 6.79 & 14.39 & 7.76 & 13.24 & $\S$ & 16.49 & 12.97 & 7.82 & 6.6 \\
\hline Cryptosporidiosis, total & 1.23 & 1.93 & 2.05 & 3.73 & 3.02 & 2.52 & 2.91 & 3 & 2.56 & 2.89 & 2.72 \\
\hline confirmed & १ & १ & १ & १ & 9 & 2.43 & 2.73 & 1.98 & 1.68 & 1.82 & 1.75 \\
\hline probable & १ & १ & 9 & १ & 9 & 0.09 & 0.19 & 1.01 & 0.87 & 1.06 & 0.98 \\
\hline Cyclosporiasis & 0.14 & 0.24 & 0.06 & 0.04 & 0.05 & 0.05 & 0.07 & 0.05 & 0.04 & 0.28 & 0.14 \\
\hline \multicolumn{12}{|l|}{ Dengue virus infection $\S$} \\
\hline Dengue fever & ๑ & १ & ๆ & ๑ & ๆ & १ & 0.22 & 0.08 & 0.17 & 0.27 & 0.21 \\
\hline Dengue hemorrhagic fever & ๆ & ๆ & ๆ & 9 & ๆ & ๆ & 0 & 0 & 0 & 0 & 0 \\
\hline Diphtheria & - & - & - & - & - & - & - & - & - & - & 0 \\
\hline \multicolumn{12}{|l|}{ Ehrlichiosis } \\
\hline human granulocytic (HGE) & 0.2 & 0.28 & 0.23 & 0.31 & 9 & १ & ๆ & १ & 9 & 9 & १ \\
\hline human monocytic (HME) & 0.12 & 0.18 & 0.2 & 0.3 & q & 9 & ף & १ & 9 & 9 & 9 \\
\hline human (other and unspecified) & - & 0.04 & 0.08 & 0.12 & 9 & 9 & 9 & १ & 9 & 9 & 9 \\
\hline Ehrlichiosis/Anaplasmosis & & & & & & & & & & & \\
\hline Ehrlichia chaffeensis & १ & १ & १ & १ & 0.35 & 0.34 & 0.26 & 0.29 & 0.38 & 0.51 & 0.48 \\
\hline Ehrlichia ewingii & १ & १ & १ & १ & 0 & 0 & 0 & 0 & 0.01 & 0.01 & 0.01 \\
\hline Anaplasma phagocytophilum & १ & १ & ศ & ก & 0.43 & 0.42 & 0.61 & 0.88 & 0.81 & 0.93 & 0.92 \\
\hline undetermined & 9 & १ & ๆ & १ & 0.06 & 0.06 & 0.04 & 0.05 & 0.06 & 0.07 & 0.06 \\
\hline Encephalitis/meningitis, arboviral ** & & & & & & & & & & & \\
\hline California serogroup virus & 0 & १ & १ & १ & १ & १ & १ & ๑ & १ & १ & १ \\
\hline Eastern equine virus & 0 & 9 & १ & १ & 9 & १ & १ & १ & ๆ & १ & १ \\
\hline Powassan virus & 0 & १ & १ & १ & १ & १ & १ & १ & १ & १ & १ \\
\hline St. Louis virus & 0 & १ & १ & १ & १ & १ & १ & १ & १ & 9 & १ \\
\hline West Nile virus & 0.43 & १ & १ & १ & १ & १ & ๆ & 9 & १ & १ & १ \\
\hline Western equine virus & - & १ & 9 & १ & 9 & ๆ & ๆ & 9 & 9 & 9 & 9 \\
\hline Enterohemorrhagic Escherichia coli & & & & & & & & & & & \\
\hline O157:H7 & 0.87 & 0.89 & १ & १ & q & १ & 9 & 9 & 9 & १ & ๆ \\
\hline non-0157 & 0.13 & 0.19 & 9 & १ & १ & १ & १ & १ & १ & १ & ๆ \\
\hline not serogrouped & 0.13 & 0.16 & ๆ & १ & 9 & ก & 9 & ๆ & 9 & १ & १ \\
\hline Giardiasis & 8.35 & 7.82 & 7.28 & 7.66 & 7.41 & 7.37 & 7.64 & 6.42 & 5.87 & 5.8 & 5.79 \\
\hline Gonorrhea $^{\dagger+}$ & 113.52 & 115.64 & 120.9 & 118.9 & 111.64 & 99.05 & 100.76 & 104.14 & 107.46 & 106.09 & 109.79 \\
\hline
\end{tabular}

See table footnotes on next page. 
TABLE 7. (Continued) Rate of notifiable diseases, ${ }^{*}$ excluding U.S. territories, by year — United States, 2004-2014

\begin{tabular}{|c|c|c|c|c|c|c|c|c|c|c|c|}
\hline Disease & 2004 & 2005 & 2006 & 2007 & 2008 & 2009 & 2010 & 2011 & 2012 & 2013 & $2014^{*}$ \\
\hline \multicolumn{12}{|l|}{ Haemophilus influenzae, invasive disease } \\
\hline $\begin{array}{l}\text { all ages, serotypes } \\
\text { age }<5 \text { yrs }\end{array}$ & 0.72 & 0.78 & 0.82 & 0.85 & 0.96 & 0.99 & 1.03 & 1.15 & 1.1 & 1.21 & 1.11 \\
\hline serotype b & 0.03 & 0.04 & 0.14 & 0.11 & 0.14 & 0.18 & 0.11 & 0.06 & 0.15 & 0.16 & 0.2 \\
\hline non-b serotype* & 0.04 & 0.67 & 0.86 & 0.97 & 1.18 & 1.17 & 0.94 & 0.57 & 1.02 & 1.11 & ब \\
\hline unknown serotype & 0.97 & 1.08 & 0.88 & 0.88 & 0.79 & 0.79 & 1.05 & 0.89 & 1.04 & 0.93 & 1.03 \\
\hline nontypeable & ก & ก & ก & ก & ก & ก & १ & १ & п & १ & 0.64 \\
\hline Hansen's disease (Leprosy) & 0.04 & 0.03 & 0.03 & 0.04 & 0.03 & 0.04 & 0.04 & 0.03 & 0.03 & 0.03 & 0.03 \\
\hline Hantavirus pulmonary syndrome & 0.01 & 0.01 & 0.01 & 0.01 & 0.01 & 0.01 & 0.01 & 0.01 & 0.01 & 0.01 & 0.01 \\
\hline Hemolytic uremic syndrome postdiarrheal & 0.07 & 0.08 & 0.11 & 0.1 & 0.12 & 0.09 & 0.09 & 0.1 & 0.09 & 0.11 & 0.08 \\
\hline \multicolumn{12}{|l|}{ Hepatitis, viral, acute } \\
\hline A acute & 1.95 & 1.53 & 1.21 & 1 & 0.86 & 0.65 & 0.54 & 0.45 & 0.5 & 0.57 & 0.39 \\
\hline B acute & 2.14 & 1.78 & 1.62 & 1.51 & 1.34 & 1.12 & 1.1 & 0.94 & 0.93 & 0.97 & 0.88 \\
\hline B chronic & ก & ก & १ & १ & १ & ก & १ & १ & ก & ก & 4.76 \\
\hline B perinatal infection & - & - & - & - & - & - & - & - & 0.01 & 0.02 & 0.01 \\
\hline Cacute & 0.31 & 0.23 & 0.26 & 0.28 & 0.29 & 0.27 & 0.29 & 0.42 & 0.59 & 0.71 & 0.73 \\
\hline C past and present & १ & १ & १ & १ & ? & १ & १ & १ & १ & १ & 65.7 \\
\hline Human immunodeficiency virus (HIV) diagnoses & - & - & - & - & - & 12.13 & 11.64 & 11.32 & 11.26 & 11.06 & 11.2 \\
\hline Influenza-associated pediatric mortality ${ }^{\dagger+\dagger}$ & $\S$ & 0.02 & 0.07 & 0.1 & 0.12 & 0.48 & 0.08 & 0.17 & 0.07 & 0.22 & 0.19 \\
\hline Invasive pneumococcal disease, all ages & - & - & - & - & - & - & - & - & 7.72 & 8.3 & 7.02 \\
\hline age $<5$ years & - & - & - & - & - & - & - & - & 8.35 & 7.8 & 7.14 \\
\hline Legionellosis & 0.71 & 0.78 & 0.96 & 0.91 & 1.05 & 1.16 & 1.09 & 1.36 & 1.19 & 1.58 & 1.62 \\
\hline Leptospirosis & ก & १ & १ & १ & ก & ก & १ & ก & ก & ก & 0.01 \\
\hline Listeriosis & 0.32 & 0.31 & 0.3 & 0.27 & 0.25 & 0.28 & 0.27 & 0.28 & 0.23 & 0.23 & 0.24 \\
\hline Lyme disease, total $\S_{\S \S}$ & ก & ก & ก & १ & 11.67 & 12.71 & 9.86 & 10.78 & 9.96 & 11.62 & 10.54 \\
\hline confirmed & 6.84 & 7.94 & 6.75 & 9.21 & 9.59 & 9.85 & 7.38 & 7.92 & 7.1 & 8.71 & 7.99 \\
\hline probable & १ & १ & ๆ & १ & 2.08 & 2.8 & 2.49 & 2.84 & 2.84 & 2.91 & 2.55 \\
\hline Malaria & 0.51 & 0.51 & 0.5 & 0.47 & 0.42 & 0.48 & 0.58 & 0.56 & 0.48 & 0.51 & 0.52 \\
\hline Measles, total & 0.01 & 0.02 & 0.02 & 0.01 & 0.05 & 0.02 & 0.02 & 0.06 & 0.02 & 0.06 & 0.21 \\
\hline indigenous & - & - & - & - & - & - & - & - & 0.01 & 0.04 & 0.19 \\
\hline imported & - & - & - & - & - & - & - & - & 0.01 & 0.02 & 0.02 \\
\hline \multicolumn{12}{|l|}{ Meningococcal disease, invasive } \\
\hline all serogroups & 0.47 & 0.42 & 0.4 & 0.36 & 0.39 & 0.32 & 0.27 & 0.25 & 0.18 & 0.18 & 0.14 \\
\hline serogroups ACWY & ก & 0.1 & 0.11 & 0.11 & 0.11 & 0.1 & 0.09 & 0.08 & 0.05 & 0.05 & 0.04 \\
\hline serogroup B & १ & 0.05 & 0.07 & 0.06 & 0.06 & 0.06 & 0.04 & 0.05 & 0.04 & 0.03 & 0.03 \\
\hline other serogroup & ๆ & 0.01 & 0.01 & 0.01 & 0.01 & 0.01 & 0 & 0.01 & 0.01 & 0.01 & 0.01 \\
\hline serogroup unknown & ก & 0.26 & 0.22 & 0.18 & 0.2 & 0.16 & 0.13 & 0.1 & 0.08 & 0.09 & 0.06 \\
\hline Mumps & 0.09 & 0.11 & 2.22 & 0.27 & 0.15 & 0.65 & 0.85 & 0.13 & 0.07 & 0.19 & 0.38 \\
\hline Novel influenza A virus infections & $\S$ & $\S$ & $\S$ & 0 & 0 & 14.37 & 0 & 0 & 0.1 & 0.1 & 0 \\
\hline Pertussis & 8.88 & 8.72 & 5.27 & 3.49 & 4.4 & 5.54 & 8.97 & 6.06 & 15.49 & 9.12 & 10.34 \\
\hline Plague & 0 & 0 & 0.01 & 0 & 0 & 0 & 0 & 0 & 0 & 0 & 0 \\
\hline Poliomyelitis, paralytic & 0 & 0 & 0 & - & - & 0 & - & - & - & - & - \\
\hline Poliovirus infection, nonparalytic & १ & q & ก & - & - & - & - & - & - & - & - \\
\hline Psittacosis & 0 & 0.01 & 0.01 & 0 & 0 & 0 & 0 & 0 & 0 & 0 & 0 \\
\hline Q Fever, total ${ }^{* * * *}$ & 0.03 & 0.05 & 0.06 & 0.06 & 0.04 & 0.04 & 0.04 & 0.04 & 0.04 & 0.05 & 0.05 \\
\hline acute & १ & १ & १ & ก & 0.04 & 0.03 & 0.04 & 0.04 & 0.04 & 0.04 & 0.04 \\
\hline chronic & १ & १ & १ & १ & 0 & 0.01 & 0.01 & 0.01 & 0.01 & 0.01 & 0.01 \\
\hline \multicolumn{12}{|l|}{ Rabies } \\
\hline animal & 0 & 0 & 0 & 0 & 0 & 0 & 0 & 0 & 1.48 & 1.41 & 1.98 \\
\hline human & 0 & 0 & 0 & 0 & 0 & 0 & 0 & 0 & 0 & 0 & 0 \\
\hline Rubella & 0 & 0 & 0 & 0 & 0.01 & 0 & 0 & 0 & 0 & 0 & 0 \\
\hline Rubella, congenital syndrome & 0 & 0 & 0 & 0 & - & - & 0 & - & 0 & 0 & 0 \\
\hline Salmonellosis & 14.47 & 15.43 & 15.45 & 16.03 & 16.92 & 16.18 & 17.73 & 16.79 & 17.27 & 16.13 & 16.14 \\
\hline SARS-CoV $++t \dagger$ & - & - & - & - & - & - & - & - & - & - & - \\
\hline Shiga toxin-producing E. coli (STEC) & ๆ & १ & 1.71 & 1.62 & 1.76 & 1.53 & 1.78 & 1.96 & 2.08 & 2.13 & 1.94 \\
\hline Shigellosis & 4.99 & 5.51 & 5.23 & 6.6 & 7.5 & 5.24 & 4.82 & 4.32 & 4.9 & 4.06 & 6.51 \\
\hline Spotted Fever Rickettsiosis, total ${ }^{\S \S \S}$ & ๆ & १ & १ & १ & 0.85 & 0.6 & 0.65 & 0.91 & 1.44 & 1.08 & 1.18 \\
\hline confirmed & 0.6 & 0.66 & 0.8 & 0.77 & 0.06 & 0.05 & 0.05 & 0.08 & 0.06 & 0.06 & 0.04 \\
\hline probable & ก & ก & ก & १ & 0.78 & 0.55 & 0.59 & 0.83 & 1.38 & 1.02 & 1.14 \\
\hline Smallpox & - & - & - & - & - & - & - & - & - & - & - \\
\hline Streptococcal disease, invasive, group A & 1.82 & 2 & 2.24 & 1.89 & 2.3 & 2.13 & $\S$ & $\S$ & $\S$ & $\S$ & $\S$ \\
\hline Streptococcal, toxic shock syndrome & 0.06 & 0.07 & 0.06 & 0.06 & 0.07 & 0.08 & 0.07 & 0.09 & 0.1 & 0.11 & 0.12 \\
\hline
\end{tabular}


Morbidity and Mortality Weekly Report

TABLE 7. (Continued) Rate of notifiable diseases,* excluding U.S. territories, by year — United States, 2004-2014

\begin{tabular}{|c|c|c|c|c|c|c|c|c|c|c|c|}
\hline Disease & 2004 & 2005 & 2006 & 2007 & 2008 & 2009 & 2010 & 2011 & 2012 & 2013 & $2014^{*}$ \\
\hline \multicolumn{12}{|l|}{ 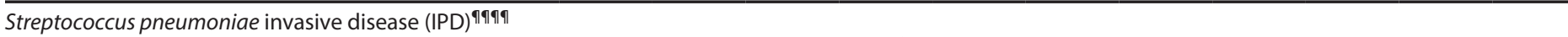 } \\
\hline all ages & 9 & п & १ & १ & १ & १ & 8.83 & 8.52 & - & - & - \\
\hline age $<5$ yrs & ๆ & ๆ & ๆ & १ & ๆ & १ & 14.15 & 7.64 & - & - & - \\
\hline \multicolumn{12}{|l|}{ Streptococcus pneumoniae invasive disease } \\
\hline drug resistant, all ages & 1.49 & 1.42 & 2.19 & 1.49 & 1.6 & 1.75 & १ & १ & १ & ๆ & १ \\
\hline age $<5$ yrs & - & - & - & 3.73 & 3.51 & 4.54 & १ & १ & १ & १ & १ \\
\hline nondrug resistant, age $<5 \mathrm{yrs}$ & 8.22 & 8.21 & 11.93 & 13.59 & 13.36 & 12.93 & १ & १ & १ & ก & १ \\
\hline \multicolumn{12}{|l|}{ Syphilist† } \\
\hline all stages & 11.94 & 11.33 & 12.46 & 13.67 & 15.34 & 14.74 & 14.93 & 14.9 & 16.02 & 17.99 & 19.9 \\
\hline congenital & 9.12 & 8.24 & 9.07 & 10.46 & 10.12 & 9.9 & 8.85 & 8.68 & 8.12 & 8.83 & 11.6 \\
\hline primary and secondary & 2.71 & 2.97 & 3.29 & 3.83 & 4.48 & 4.6 & 4.49 & 4.52 & 5.03 & 5.54 & 6.27 \\
\hline Tetanus & 0.01 & 0.01 & 0.01 & 0.01 & 0.01 & 0.01 & 0.01 & 0.01 & 0.01 & 0.01 & 0.01 \\
\hline Toxic shock syndrome & 0.04 & 0.04 & 0.05 & 0.04 & 0.03 & 0.03 & 0.04 & 0.03 & 0.03 & 0.03 & 0.03 \\
\hline Trichinellosis & 0 & 0.01 & 0.01 & 0 & 0.01 & 0 & 0 & 0.01 & 0.01 & 0.01 & 0 \\
\hline Tuberculosis***** & 5.09 & 4.8 & 4.65 & 4.44 & 4.28 & 3.8 & 3.64 & 3.41 & 3.19 & 3.05 & 2.95 \\
\hline Tularemia & 0.05 & 0.05 & 0.03 & 0.05 & 0.04 & 0.03 & 0.04 & 0.05 & 0.05 & 0.06 & 0.06 \\
\hline Typhoid fever & 0.11 & 0.11 & 0.12 & 0.14 & 0.15 & 0.13 & 0.15 & 0.13 & 0.11 & 0.11 & 0.11 \\
\hline Vancomycin-intermediate Staphylococcus aureus & - & 0 & 0 & 0.02 & 0.03 & 0.03 & 0.04 & 0.04 & 0.06 & 0.1 & 0.08 \\
\hline Vancomycin-resistant Staphylococcus aureus & 0 & 0 & 0 & 0 & 0 & 0 & 0 & - & - & - & - \\
\hline Varicella (chickenpox morbidity) & 18.41 & 19.64 & 28.65 & 18.68 & 13.56 & 8.71 & 6.46 & 5.79 & 5.33 & 4.62 & 3.94 \\
\hline Varicella (chickenpox mortality) & - & - & - & - & - & - & - & - & 0 & 0 & 0 \\
\hline Vibriosis & १ & १ & आ & 0.25 & 0.24 & 0.3 & 0.3 & 0.29 & 0.39 & 0.43 & 0.42 \\
\hline Viral hemorrhagic fevers & १ & १ & ๆ & ก & 9 & 9 & 0 & 0 & 0 & 0 & 0 \\
\hline Yellow fever ${ }^{\S,+++†+~}$ & - & - & - & - & - & - & - & - & - & - & - \\
\hline
\end{tabular}

* Per 100,000 population. No cases of anthrax; dengue hemorrhagic fever (and dengue shock syndrome), eastern equine encephalitis, nonneuroinvasive disease; poliomyelitis, paralytic; poliovirus infection, nonparalytic; severe acute respiratory syndrome-associated Coronavirus disease (SARS-CoV); smallpox; vancomycinresistant Staphylococcus aureus (VRSA); western equine encephalitis, neuroinvasive and nonneuroinvasive disease; or yellow fever were reported in the United States during 2014.

${ }^{\dagger}$ In 2008 CDC published a revised HIV case definition. This combined separate surveillance case definitions for HIV infection and AIDS into a single case definition for HIV infection that includes AIDS (and incorporates the HIV infection classification system). The revised HIV case definition provides a more complete presentation of the HIV epidemic on a population level. Please see the Centers for Disease Control and Prevention revised surveillance case definitions for HIV infection among adults, adolescents, and children aged $<18$ months and for HIV infection and AIDS among children aged 18 months to $<13$ years-United States, 2008 . MMWR Recomm Rep 2008;57(No. RR-10). These case counts can be found under "HIV Diagnoses" in this table. The total number of HIV Diagnoses includes all cases reported to the Division of HIV/AIDS Prevention, National Center for HIV/AIDS, Viral Hepatitis, STD, and TB Prevention (NCHHSTP), through December 31, 2012. AIDS: Acquired Immunodeficiency Syndrome. HIV: Human Immunodeficiency Virus.

$\S$ Totals reported to the Division of Vector-Borne Diseases, National Center for Emerging and Zoonotic Infectious Diseases (ArboNET Surveillance), as of July 1, 2015.

" Not nationally notifiable.

** Revision of National Surveillance Case Definition distinguishing between confirmed and probable cases for annual report only (weekly reports contain total cases).

t+ Total reported to the Division of STD Prevention, NCHHSTP, as of June 10, 2015.

$\S \S$ Reportable in $<25$ states.

กा As of 2008, these categories were replaced with codes for Anaplasma phagocytophilum. Refer to Ehrlichiosis/Anaplasmosis.

*** In 2005, the arboviral disease surveillance case definitions and categories were revised. The nationally notifiable arboviral encephalitis and meningitis conditions continued to be nationally notifiable in 2005 and 2006, but under the category of arboviral neuroinvasive disease.

t+† Totals reported to the Division of Influenza, National Center for Immunization and Respiratory Diseases, as of December 28, 2014.

$\S \S \S$ The National surveillance case definition was revised in 2008; probable cases not previously reported.

กาๆ To help public health specialists monitor the impact of the new meningococcal conjugate vaccine (Menactra ${ }^{\circledR}$, licensed in the United States in January 2005), the data display for meningococcal disease was modified to differentiate the fraction of the disease that is vaccine preventable (serogroups A,C,Y, W-135) from the nonpreventable fraction of disease (serogroup B and others).

*** In 2008, Q fever acute and chronic reporting categories were recognized as a result of revision to the Q fever case definition. Before that time, case counts were not differentiated relative to acute and chronic $Q$ fever cases.

tttt Severe acute respiratory syndrome-associated coronavirus disease.

$\S \S \S$ Revision of the National Surveillance Case Definition distinguishing between confirmed and probable cases; total case count includes eight case reports with unknown case status in 2014

ๆศศศ Streptococcus pneumoniae invasive disease drug resistant (all ages) (11720) and nondrug resistant age $<5$ years (11717) became Streptococcus pneumoniae invasive disease (IPD) (11723) from 2010 through 2011 and finally simply invasive pneumococcal disease (IPD) (11723) starting in 2012.

***** Totals reported to the Division of Tuberculosis Elimination, NCHHSTP, as of July 15, 2015.

${ }^{++t+\dagger}$ The last indigenous case of yellow fever was reported in 1911; all other case reports since 1911 have been imported. 
TABLE 8. Number of deaths from selected nationally notifiable infectious diseases — United States, 2008-2014*

\begin{tabular}{|c|c|c|c|c|c|c|c|c|}
\hline \multirow[b]{2}{*}{ Cause of death } & \multirow{2}{*}{$\begin{array}{c}\text { ICD- } 10^{\dagger} \\
\text { Cause of death code }\end{array}$} & \multicolumn{7}{|c|}{ No. of Deaths } \\
\hline & & 2008 & 2009 & 2010 & 2011 & 2012 & 2013 & 2014 \\
\hline Anthrax & A22 & 0 & 0 & 0 & 0 & 0 & 0 & 0 \\
\hline Babesiosis & B60.0 & 7 & 6 & 4 & 5 & 4 & 6 & 7 \\
\hline Botulism, foodborne & A05.1 & 4 & 3 & 0 & 0 & 1 & 1 & 2 \\
\hline Brucellosis & A23.0-A23.9 & 0 & 1 & 0 & 1 & 0 & 1 & 0 \\
\hline Cholera (toxigenic Vibrio cholerae 01 or 0139) & $\mathrm{A} 00$ & 0 & 1 & 0 & 0 & 0 & 1 & 0 \\
\hline Coccidioidomycosis & B38 & 72 & 87 & 92 & 88 & 70 & 56 & 68 \\
\hline Cryptosporidiosis & A07.2 & 3 & 2 & 4 & 4 & 2 & 0 & 1 \\
\hline Cyclosporiasis & A07.8 & 0 & 0 & 0 & 0 & 0 & 0 & 0 \\
\hline Dengue Fever & A90 & 0 & 1 & 2 & 0 & 1 & 3 & 2 \\
\hline Dengue Hemorrhagic Fever & A91 & 0 & 0 & 1 & 0 & 1 & 0 & 0 \\
\hline Diphtheria & A36.0-A36.3, A36.9 & 0 & 0 & 0 & 0 & 0 & 0 & 0 \\
\hline $\begin{array}{l}\text { Ehrlichiosis/Anaplasmosis (Anaplasma phagocytophilum, } \\
\text { Ehrlichia chaffeensis, Ehrlichia ewingii, undetermined human } \\
\text { Ehrlichiosis/Anaplasmosis) }\end{array}$ & A77.8, A79 & 6 & 7 & 5 & 5 & 13 & 9 & 13 \\
\hline Giardiasis & A07.1 & 1 & 0 & 1 & 1 & 0 & 0 & 1 \\
\hline Haemophilus influenzae infection & A41.3, A49.2, G00.0, J14, J20.1 & 61 & 57 & 47 & 68 & 70 & 65 & 69 \\
\hline Hansen's disease (leprosy) & A30 & 2 & 1 & 4 & 1 & 0 & 0 & 0 \\
\hline Hantavirus Pulmonary Syndrome (HPS) & B33.4 & 9 & 0 & 2 & 8 & 4 & 4 & 5 \\
\hline Hemolytic uremic syndrome, postdiarrheal & D59.3 & 32 & 25 & 20 & 25 & 23 & 22 & 38 \\
\hline Hepatitis A, viral (acute) & B15 & 37 & 26 & 29 & 25 & 23 & 24 & 26 \\
\hline Hepatitis B, viral (acute, chronic, perinatal) & B16, B17.0, B18.0, B18.1 & 671 & 597 & 588 & 614 & 581 & 573 & 535 \\
\hline Hepatitis C, viral (acute, chronic) & B17.1, B18.2 & 6,834 & 6,981 & 6,844 & 7,048 & 7,292 & 7,366 & 7,349 \\
\hline Human immunodeficiency virus (HIV) infection & B20-B24 & 10,285 & 9,406 & 8,369 & 7,683 & 7,216 & 6,955 & 6,721 \\
\hline Invasive pneumococcal disease, all ages & A40.3, G00.1 & 203 & 228 & 191 & 181 & 156 & 199 & 152 \\
\hline Legionellosis & A48.1, A48.2 & 92 & 104 & 104 & 111 & 124 & 131 & 132 \\
\hline Leptospirosis & $\mathrm{A} 27.0, \mathrm{~A} 27.8, \mathrm{~A} 27.9$ & 2 & 2 & 0 & 0 & 1 & 2 & 0 \\
\hline Listeriosis & $\mathrm{A} 32, \mathrm{P} 37.2$ & 30 & 29 & 28 & 52 & 47 & 32 & 36 \\
\hline Lyme disease & A69.2, L90.4 & 10 & 12 & 10 & 6 & 11 & 5 & 15 \\
\hline Measles & B05 & 0 & 2 & 2 & 0 & 2 & 0 & 0 \\
\hline Meningococcal disease & A39.0 & 31 & 28 & 14 & 26 & 11 & 9 & 10 \\
\hline Mumps & B26 & 2 & 2 & 1 & 0 & 0 & 1 & 0 \\
\hline Pertussis & A37.0 & 6 & 1 & 5 & 1 & 4 & 2 & 7 \\
\hline Plague & A20 & 0 & 1 & 0 & 0 & 0 & 0 & 0 \\
\hline Poliomyelitis, paralytic & A80 & 0 & 0 & 0 & 0 & 0 & 0 & 0 \\
\hline Psittacosis & A70 & 0 & 0 & 0 & 0 & 0 & 0 & 0 \\
\hline Q Fever & A78 & 0 & 1 & 0 & 2 & 0 & 2 & 3 \\
\hline Rabies, human & A82 & 2 & 4 & 1 & 4 & 1 & 0 & 1 \\
\hline Rubella & B06 & 0 & 1 & 1 & 1 & 0 & 0 & 0 \\
\hline Rubella, congenital syndrome & P35.0 & 5 & 4 & 8 & 5 & 8 & 6 & 4 \\
\hline Salmonellosis & $\mathrm{A} 02$ & 42 & 26 & 28 & 44 & 44 & 40 & 45 \\
\hline Shiga toxin-producing E. coli (STEC) & A04.3 & 0 & 1 & 0 & 0 & 1 & 0 & 0 \\
\hline Shigellosis & A03 & 3 & 4 & 2 & 3 & 2 & 5 & 3 \\
\hline Spotted Fever Rickettsiosis & A77.0-A77.3, A77.9 & 4 & 8 & 8 & 6 & 4 & 7 & 8 \\
\hline Smallpox & B03 & 0 & 0 & 0 & 0 & 0 & 0 & 0 \\
\hline Tetanus & A33, A34, A35 & 3 & 6 & 3 & 6 & 4 & 3 & 1 \\
\hline Trichinellosis & B75 & 1 & 0 & 0 & 0 & 0 & 0 & 0 \\
\hline Tuberculosis & A16-A19 & 585 & 529 & 569 & 539 & 510 & 555 & 493 \\
\hline Tularemia & A21 & 1 & 3 & 0 & 0 & 0 & 2 & 1 \\
\hline Typhoid fever & A01.0 & 2 & 0 & 0 & 0 & 0 & 0 & 0 \\
\hline Varicella (chickenpox mortality) & B01 & 18 & 22 & 15 & 14 & 16 & 8 & 4 \\
\hline Vibriosis & $\mathrm{A} 05.3^{\S}$ & 1 & 0 & 0 & 0 & 0 & 0 & 0 \\
\hline \multicolumn{9}{|l|}{ Viral hemorrhagic fevers } \\
\hline Crimean-Congo hemorrhagic fever & A98.0 & 0 & 0 & 0 & 0 & 0 & 0 & 0 \\
\hline Ebola virus & A98.4 & 0 & 0 & 0 & 0 & 0 & 0 & 1 \\
\hline Lassa virus & A96.2 & 0 & 0 & 0 & 0 & 0 & 0 & 0 \\
\hline Lujo virus & A98.8 & 0 & 0 & 0 & 0 & 0 & 0 & 0 \\
\hline Marburg virus & A98.3 & 0 & 0 & 0 & 0 & 0 & 0 & 0 \\
\hline New World Arenavirus-Guanarito virus & A96.8 & 0 & 0 & 0 & 0 & 0 & 0 & 0 \\
\hline New World Arenavirus-Junin virus & A96.0 & 0 & 0 & 0 & 0 & 0 & 0 & 0 \\
\hline New World Arenavirus-Machupo virus & A96.1 & 0 & 0 & 0 & 0 & 0 & 0 & 0 \\
\hline New World Arenavirus-Sabia virus & A96.8 & 0 & 0 & 0 & 0 & 0 & 0 & 0 \\
\hline Yellow fever & A95.0, A95.1, A95.9 & 0 & 0 & 0 & 0 & 0 & 0 & 0 \\
\hline
\end{tabular}

See table footnotes on next page. 
TABLE 8. (Continued) Number of deaths from selected nationally notifiable infectious diseases — United States, 2008-2014*

Source: CDC. CDC WONDER Detailed Mortality files (http://wonder.cdc.gov/) provided by the National Center for Health Statistics, National Vital Statistics System, 1999-2014. Underlying causes of death are classified according to ICD-10. Data are limited by the accuracy of the information regarding the underlying cause of death indicated on death certificates and reported to the National Vital Statistics System.

* List of Nationally Notifiable Conditions in 2014.

† World Health Organization. International Statistical Classification of Disease and Related Health Problems. Tenth Revision, 1992.

$\S$ The mortality code listed (A05.3) specifies cause of death as "foodborne Vibrio parahaemolyticus intoxication" and might not accurately reflect mortality from other vibrio species. 



\section{PART 2 \\ Graphs and Maps for Selected Notifiable Diseases in the United States, 2014}

\begin{tabular}{|ll|}
\hline \multicolumn{3}{|c|}{ Abbreviations and Symbols Used in Graphs and Maps } \\
$\mathbf{U}$ & Data not available. \\
$\mathbf{N}$ & Not reportable (i.e., report of disease not required in that jurisdiction). \\
DC & District of Columbia \\
NYC & New York City \\
AS & American Samoa \\
CNMI & Commonwealth of Northern Mariana Islands \\
GU & Guam \\
PR & Puerto Rico \\
VI & U.S. Virgin Islands \\
\hline
\end{tabular}


ANTHRAX. Number* of reported cases, by year — United States, 1959-2014

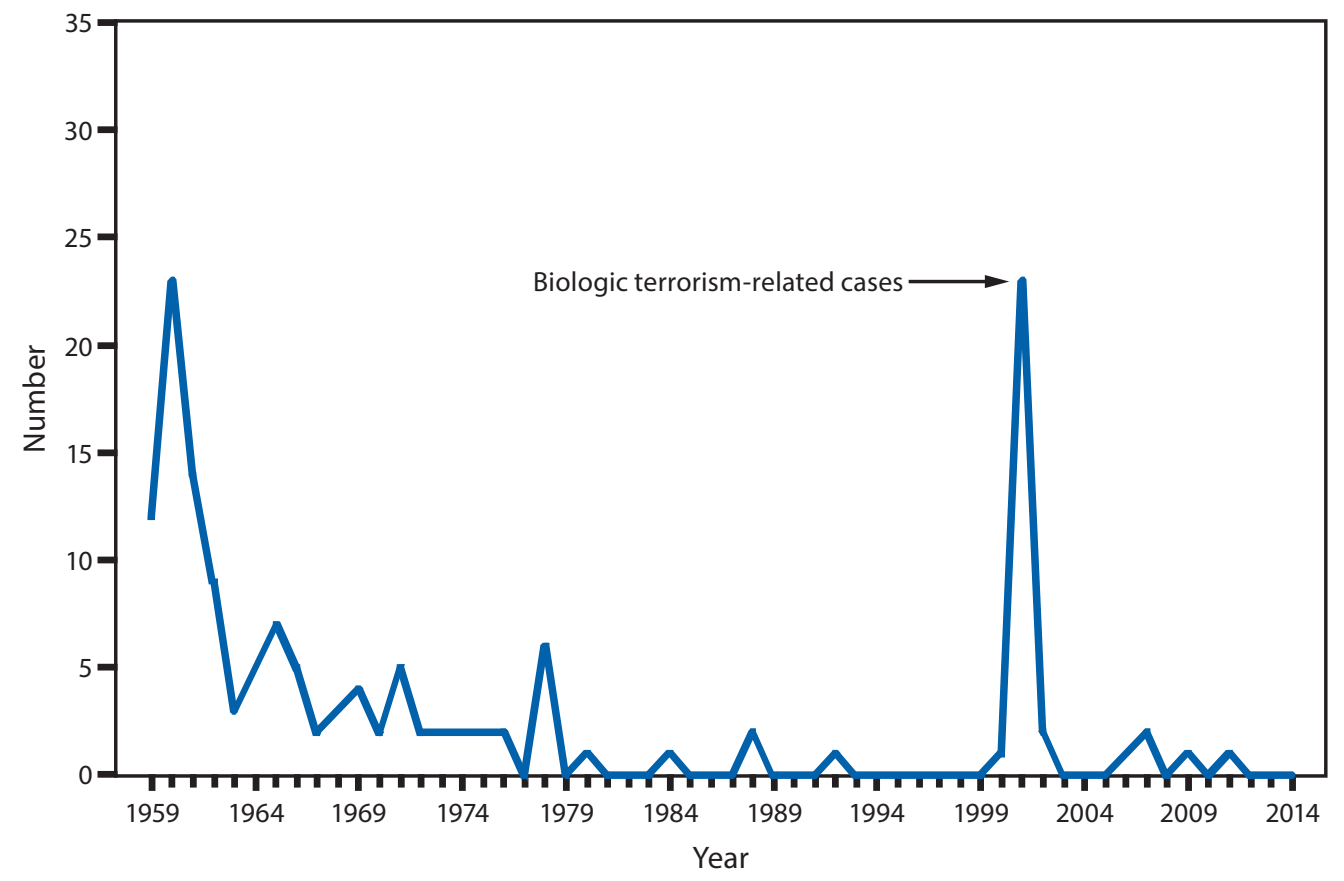

* One epizootic-associated cutaneous case was reported in 2001 from Texas.

In 2014, anthrax epizootics were reported in North Dakota, South Dakota, and Texas. Epizootics involved domestic and wildlife bovine, caprine, and cervid species. No human anthrax cases were reported in 2014 from zoonotic or other causes. 
ARBOVIRAL DISEASES. Number* of reported cases of neuroinvasive disease, by year — United States, 2005-2014

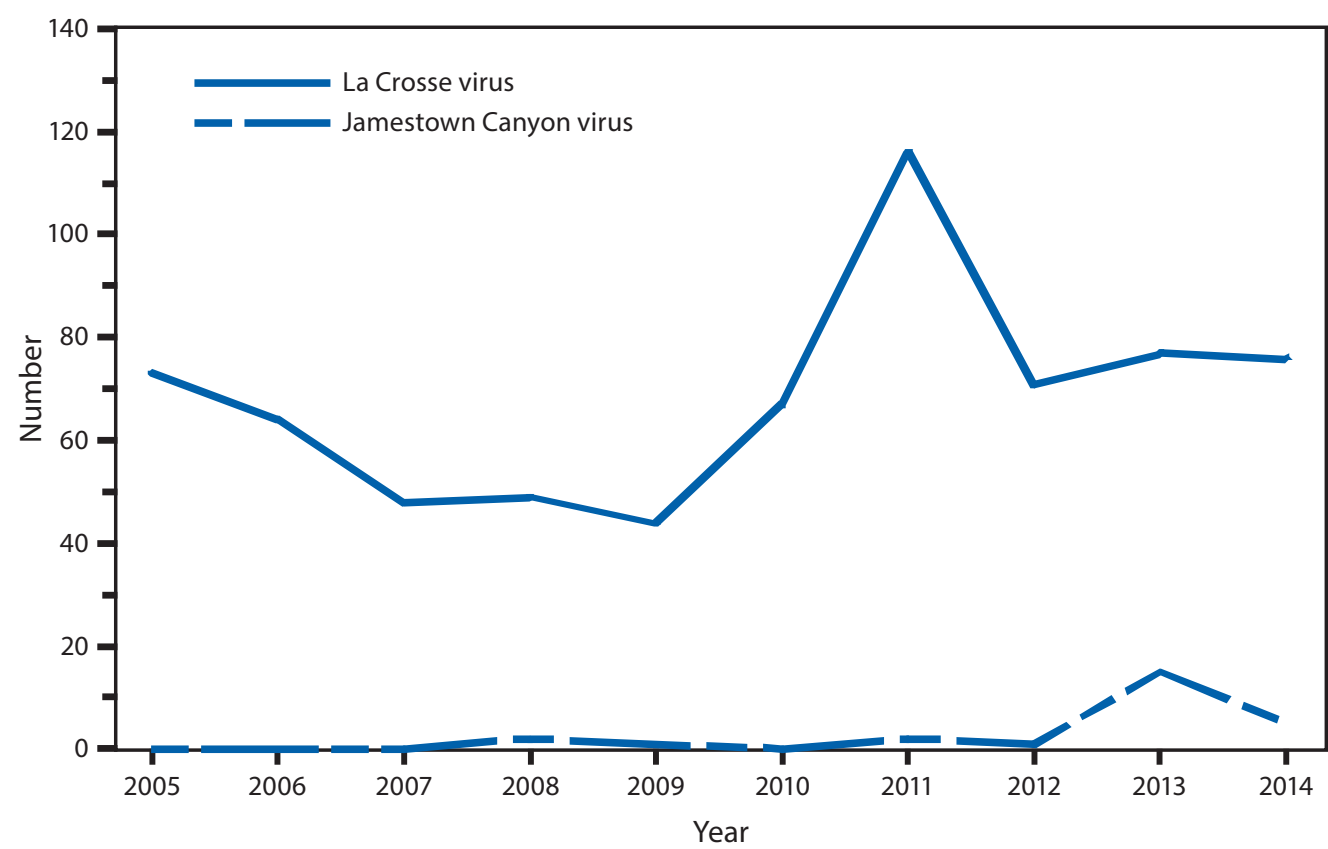

* Data from the Division of Vector-Borne Diseases, National Center for Emerging and Zoonotic Infectious Diseases (ArboNET Surveillance). Only reported cases of neuroinvasive diseases are shown.

During 2005-2014, an average of 69 La Crosse virus neuroinvasive disease cases were reported each year. La Crosse virus was the most common cause of neuroinvasive arboviral disease among children. During that same time period, Jamestown Canyon virus caused an average of two neuroinvasive disease cases per year. Starting in 2013, following the implementation of routine antibody testing for Jamestown Canyon virus disease, reported cases increased. 
ARBOVIRAL DISEASES, WEST NILE VIRUS. Incidence* of reported cases of neuroinvasive disease, by age group — United States, 2014

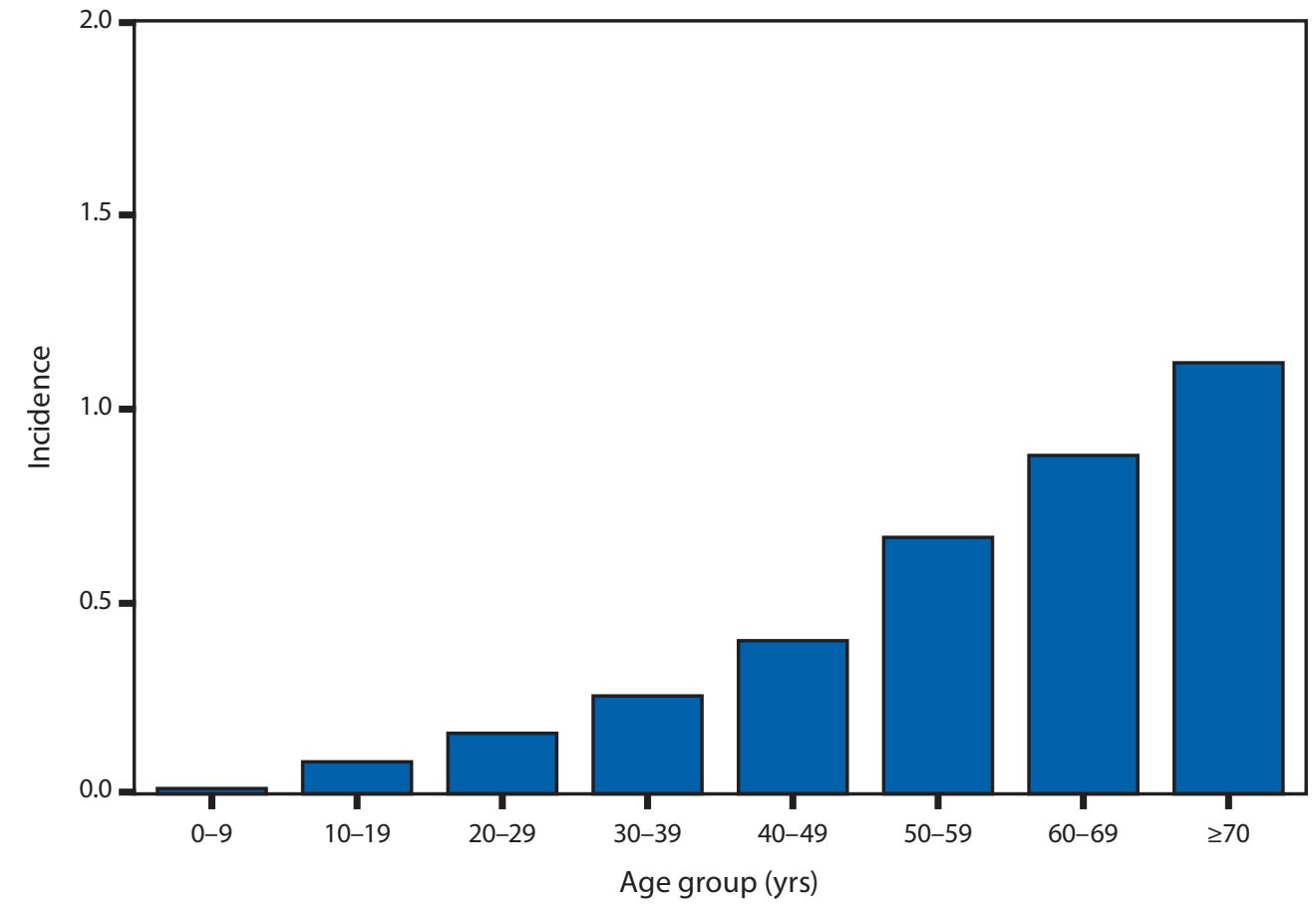

* Per 100,000 population. Data from the Division of Vector-Borne Diseases, National Center for Emerging and Zoonotic Infectious Diseases (ArboNET Surveillance).

In 2014, West Nile virus neuroinvasive disease incidence increased with increasing age, ranging from 0.03 per 100,000 among persons aged $<10$ years to 1.15 among those aged $\geq 70$ years. 
ARBOVIRAL DISEASES, WEST NILE VIRUS. Incidence* of reported cases of neuroinvasive disease United States and U.S. territories, 2014

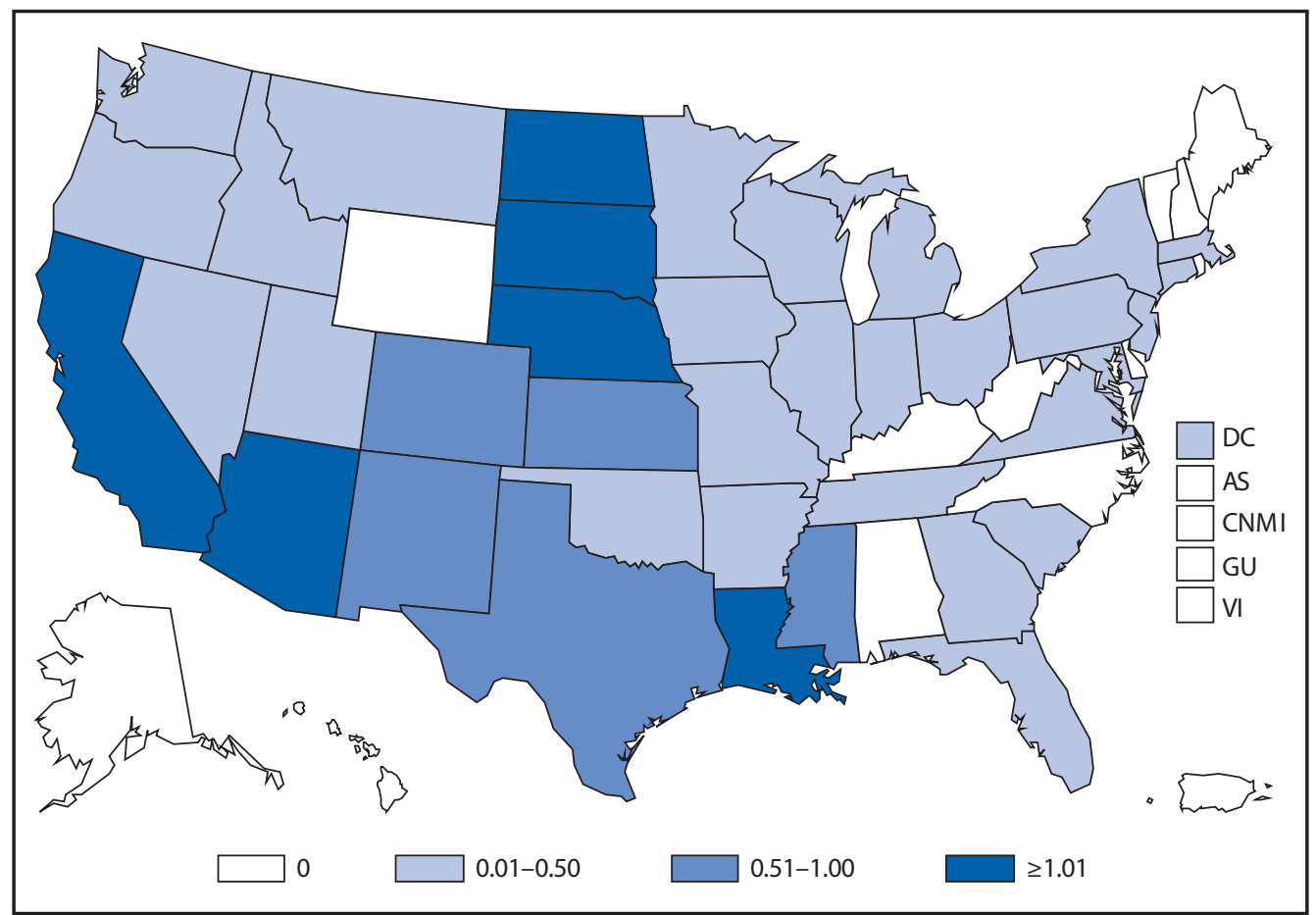

* Per 100,000 population. Data from the Division of Vector-Borne Diseases, National Center for Emerging and Zoonotic Infectious Diseases (ArboNET Surveillance).

In 2014, the states with the highest reported incidence of West Nile virus (WNV) neuroinvasive disease were Nebraska (2.2 per 100,000), North Dakota (1.6), California (1.4), South Dakota (1.4), Louisiana (1.3), and Arizona (1.2). Three states reported two thirds of WNV neuroinvasive disease cases: California (561 cases), Texas (253), and Arizona (80). 
ARBOVIRAL DISEASES, WEST NILE VIRUS. Incidence* of reported cases of neuroinvasive disease, by year — United States, 2005-2014

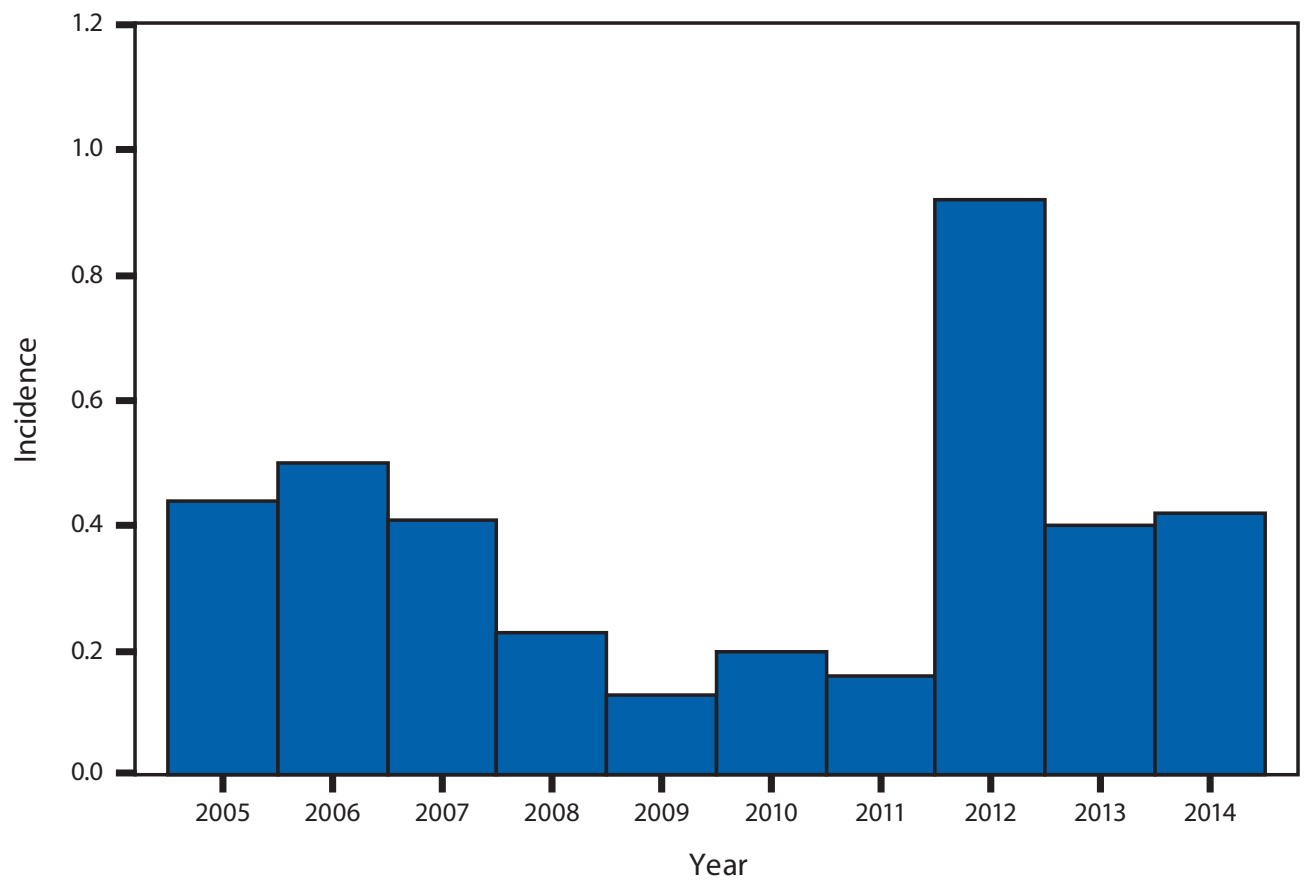

* Per 100,000 population. Data from the Division of Vector-Borne Diseases, National Center for Emerging and Zoonotic Infectious Diseases (ArboNET Surveillance).

Nationally, West Nile virus neuroinvasive disease incidence in 2014 was similar to the median incidence during 2005-2013. 
BABESIOSIS. Number of reported cases, by county — United States, 2014

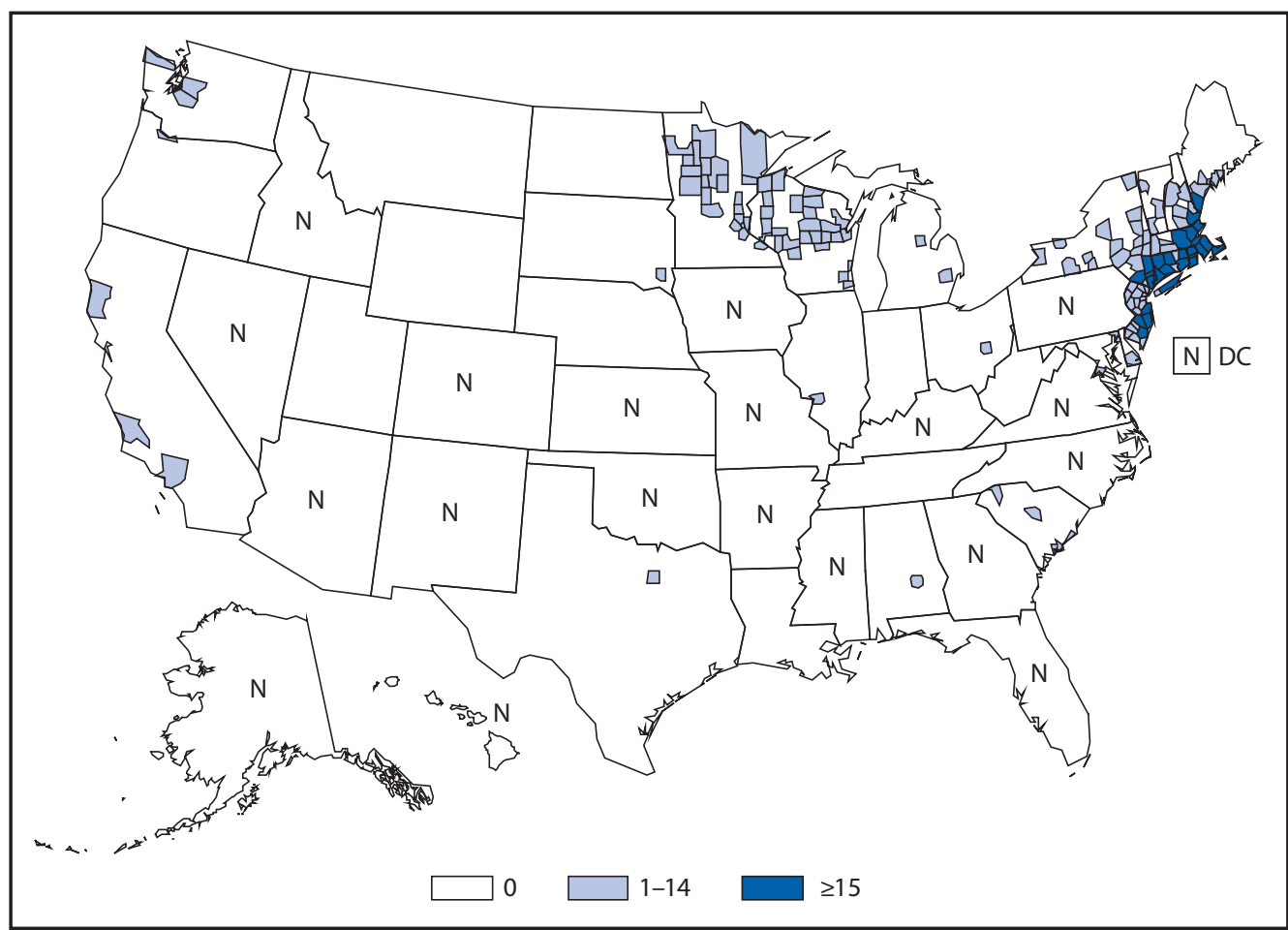

Abbreviation: $\mathrm{N}=$ not reportable.

Babesiosis, a tickborne parasitic disease, became a nationally notifiable condition in 2011. In 2014, babesiosis was reportable in 31 states. Twenty-two of the 31 states reported at least one case; however, 1,636 (94\%) of the 1,744 reported cases occurred in residents of seven of the states in which tickborne transmission of Babesia microti has been well documented (Connecticut, Massachusetts, Minnesota, New Jersey, New York, Rhode Island, and Wisconsin). 
BOTULISM, FOODBORNE. Number of reported cases, by year — United States, 1994-2014

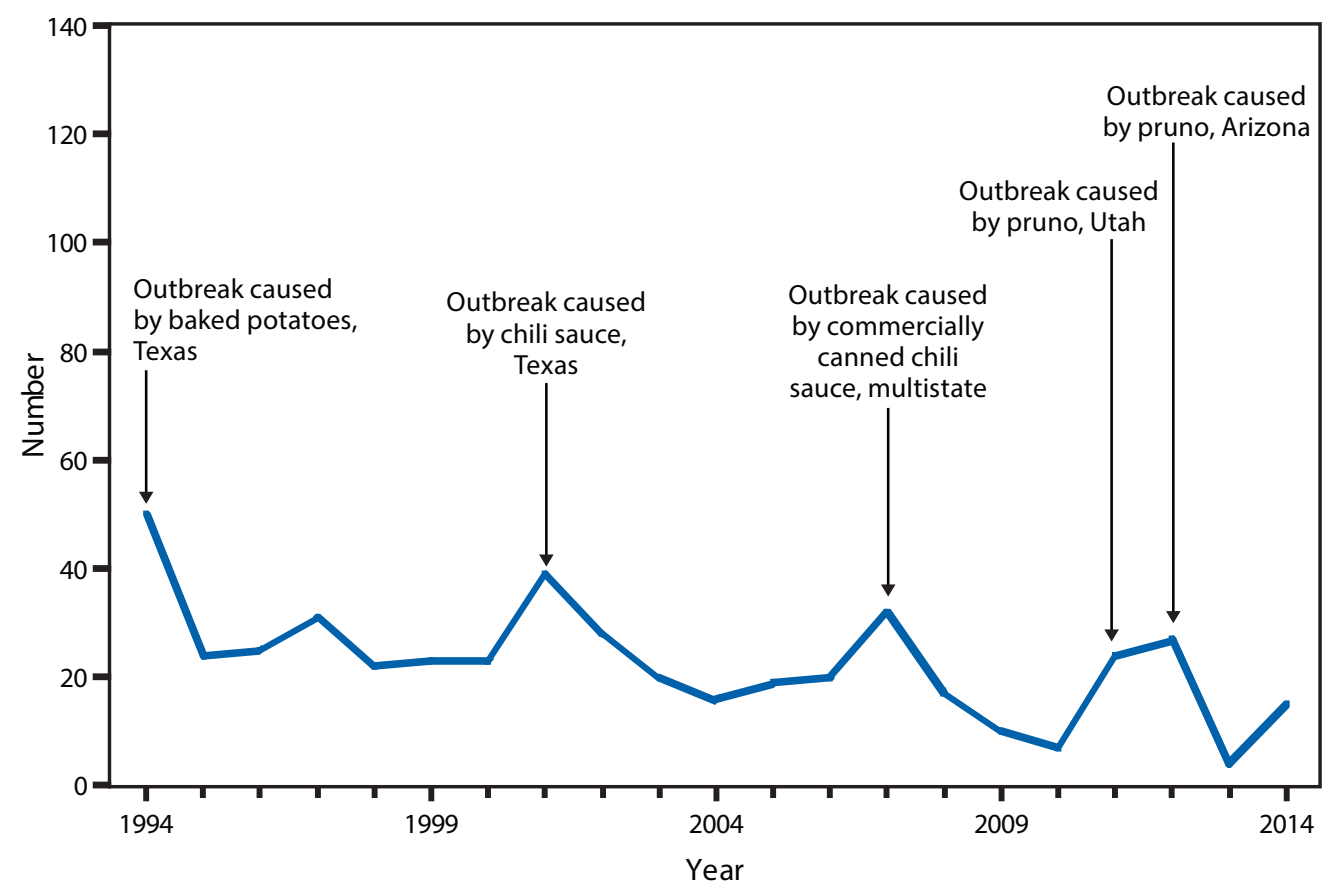

The number of foodborne botulism cases, caused by ingestion of preformed toxin, increased slightly from 2013 but remains below the average of the preceding 20 years. Pruno, which caused the 2011 and 2012 outbreaks in Utah and Arizona, respectively, is an illicit alcoholic beverage brewed by prison inmates. 
BOTULISM, INFANT. Number of reported cases, by year — United States, 1994-2014

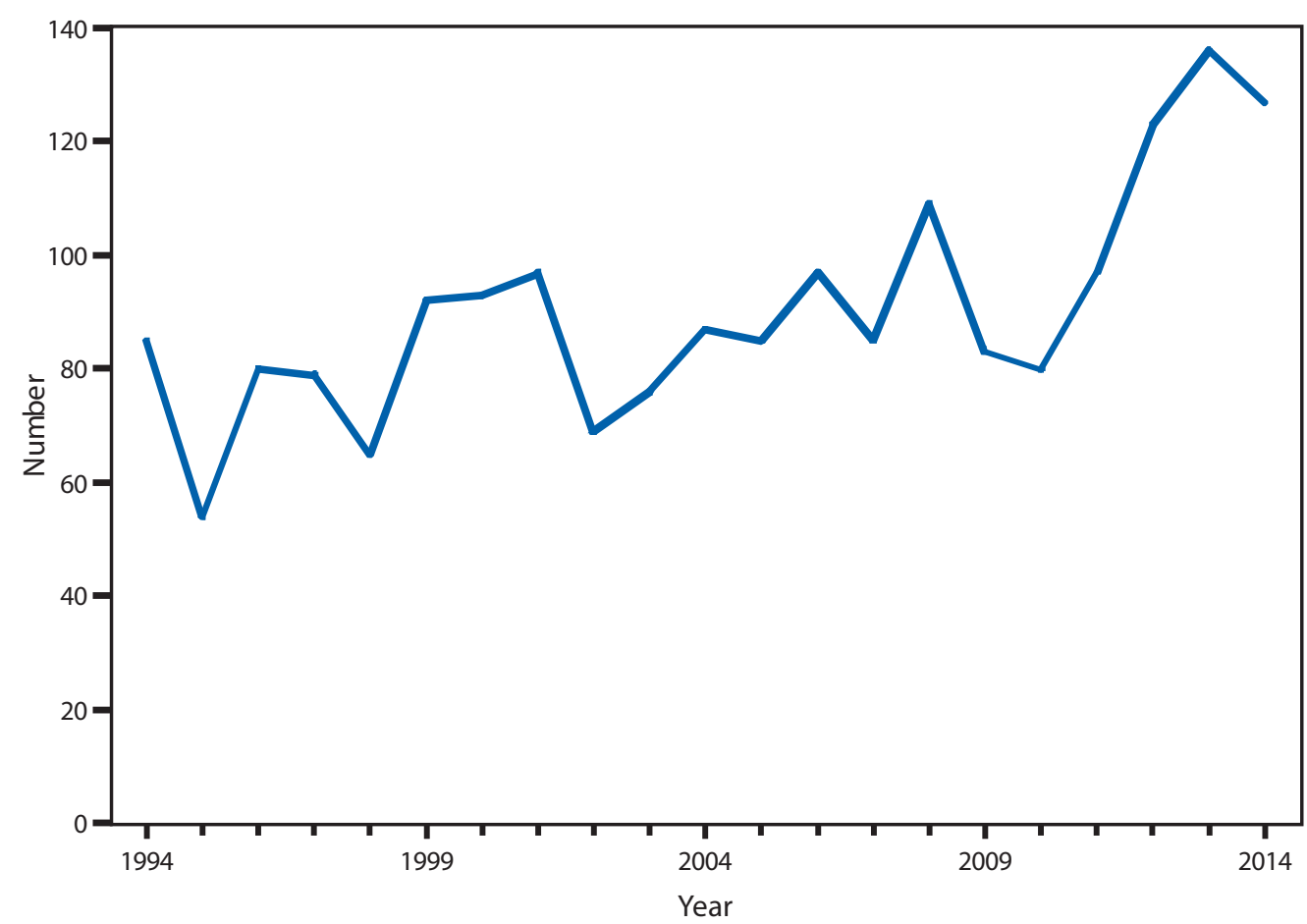

Infant botulism remains the most common transmission category of botulism in the United States and accounted for most botulism cases in 2014. Reported cases have increased since 2010, but declined slightly from 2013 to 2014. 
BOTULISM, OTHER. Number* of reported cases, by year — United States, 2004-2014

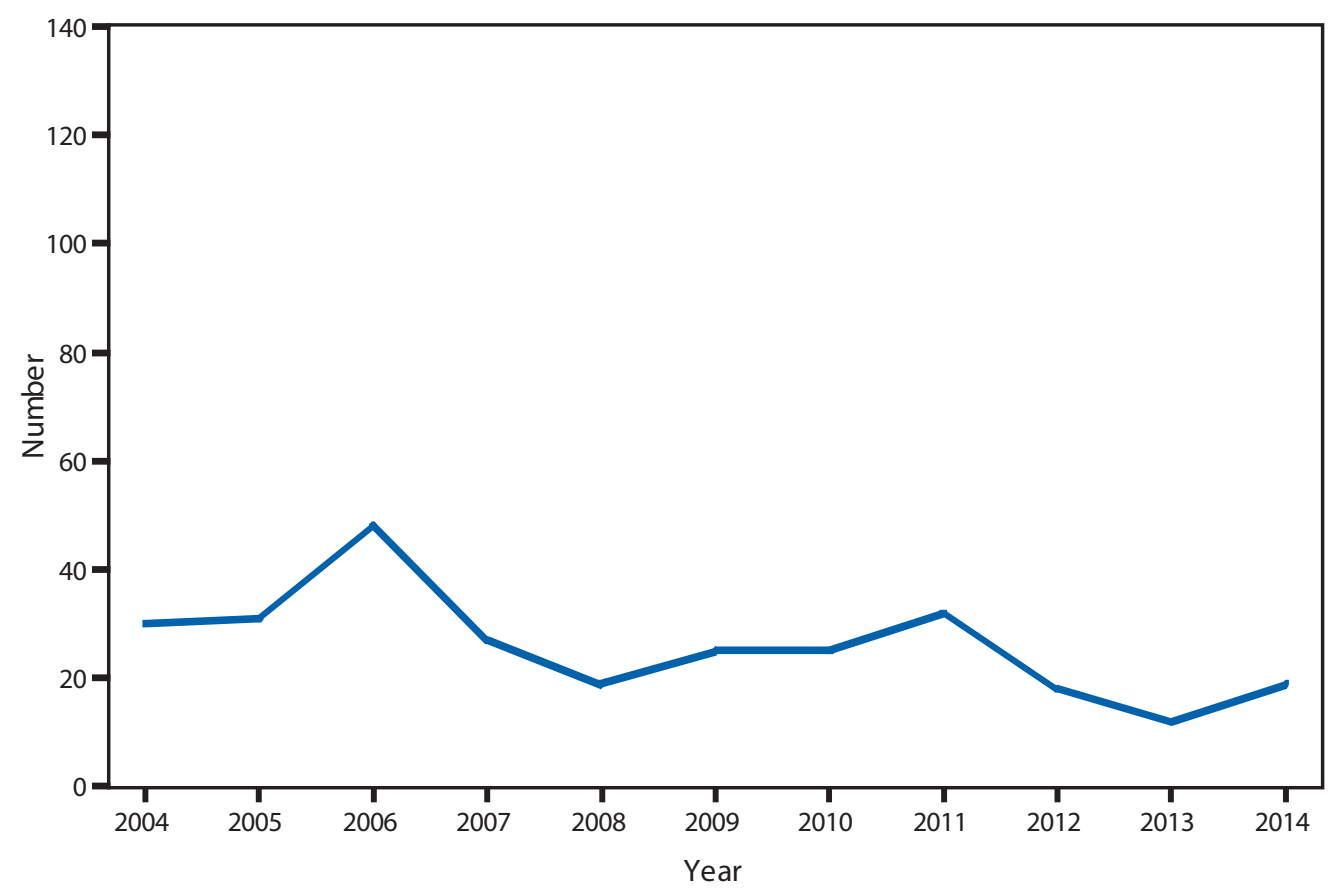

*Includes wound and unspecified.

Annual number of cases of wound botulism and of botulism in "unspecified" transmission categories have remained generally stable since 2007. 
BRUCELLOSIS. Number of reported cases — United States and U.S. territories, 2014

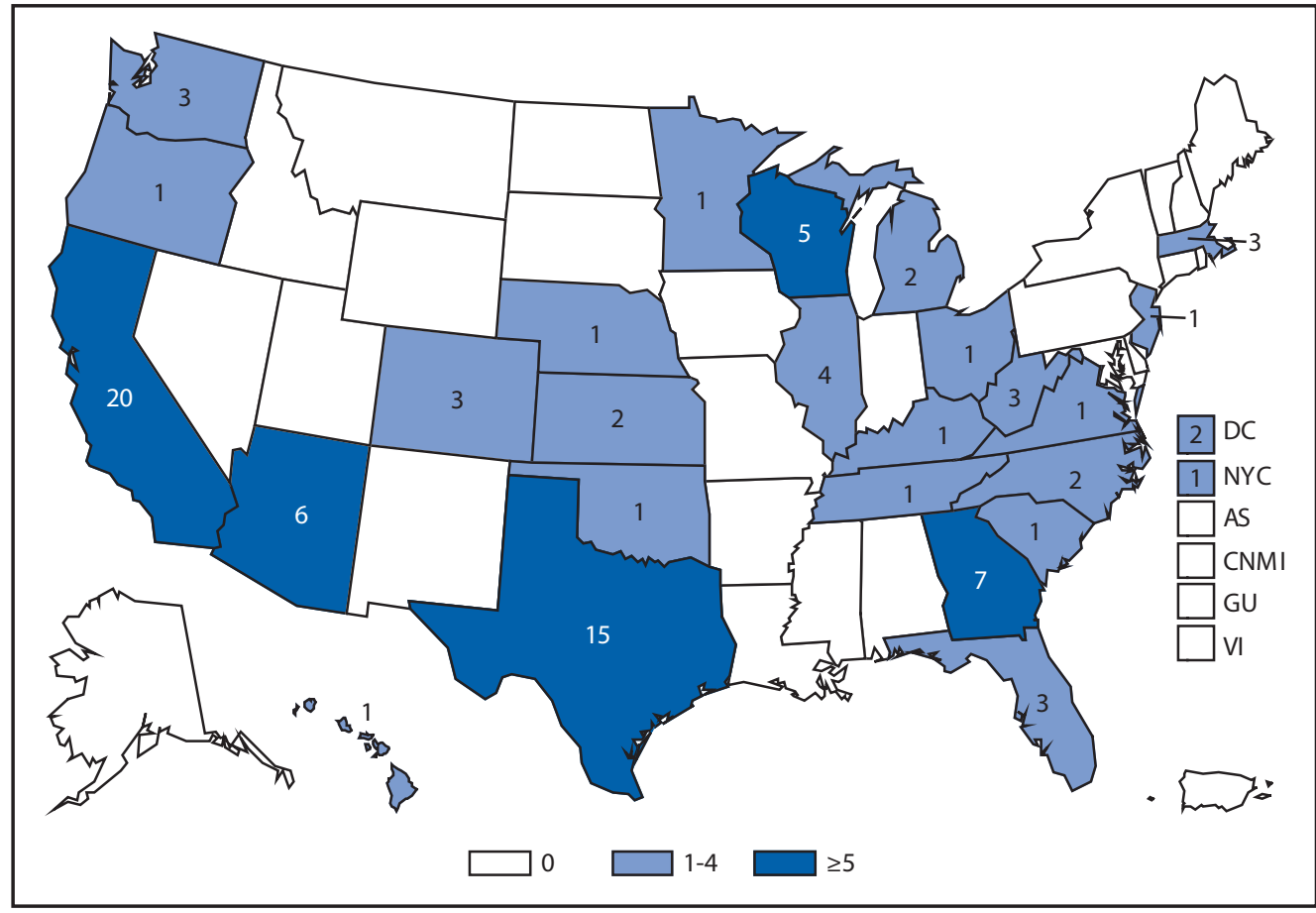

The number of states reporting more than four cases of human brucellosis decreased from 2013 to 2014. 
BRUCELLOSIS. Number of reported cases, by year — United States, 1984-2014

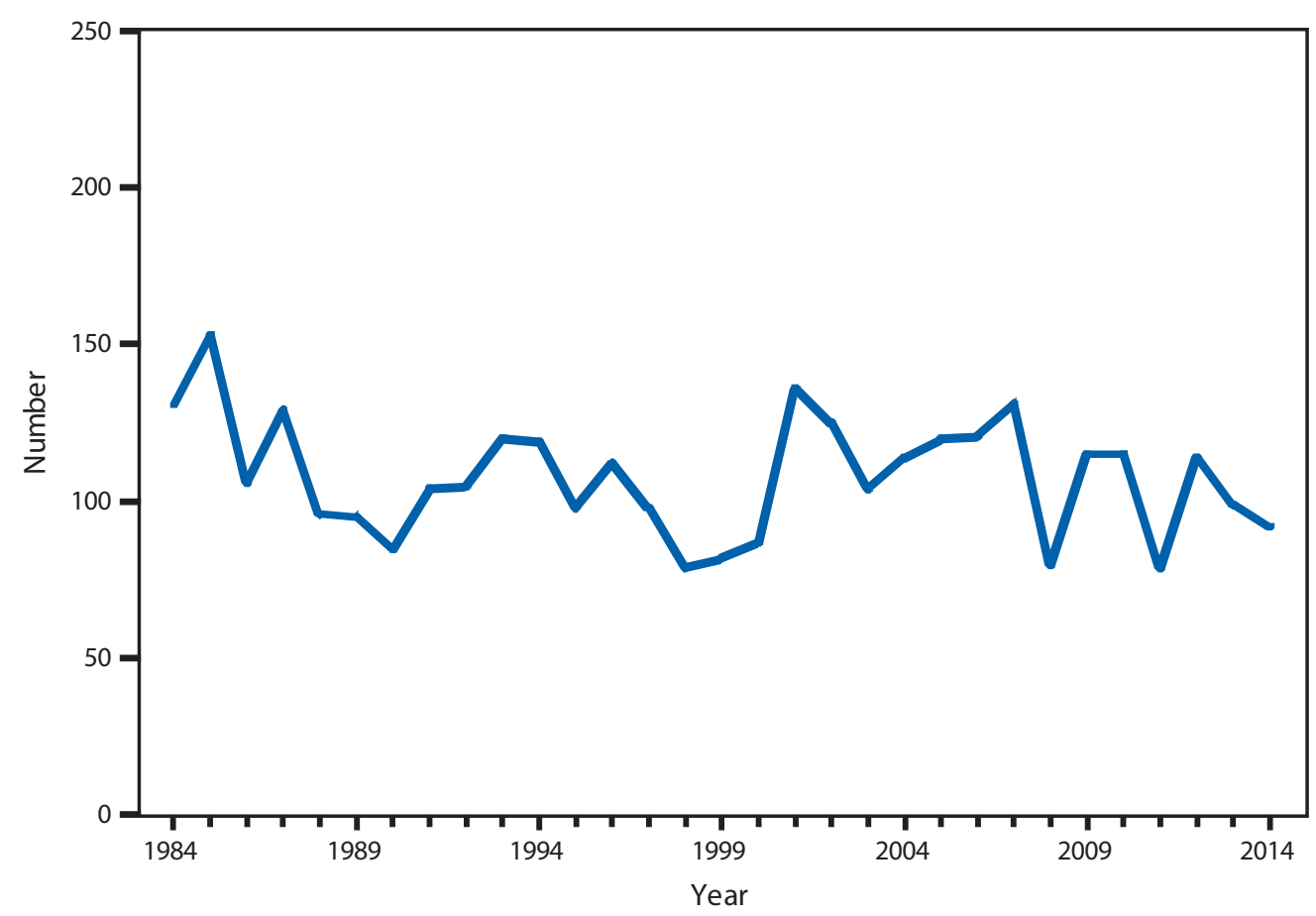

The number of annual reported cases of brucellosis has continued to decrease since 2012. 
CHLAMYDIA. Incidence* of reported cases among women aged 15-24 years - United States and U.S. Territories, 2014

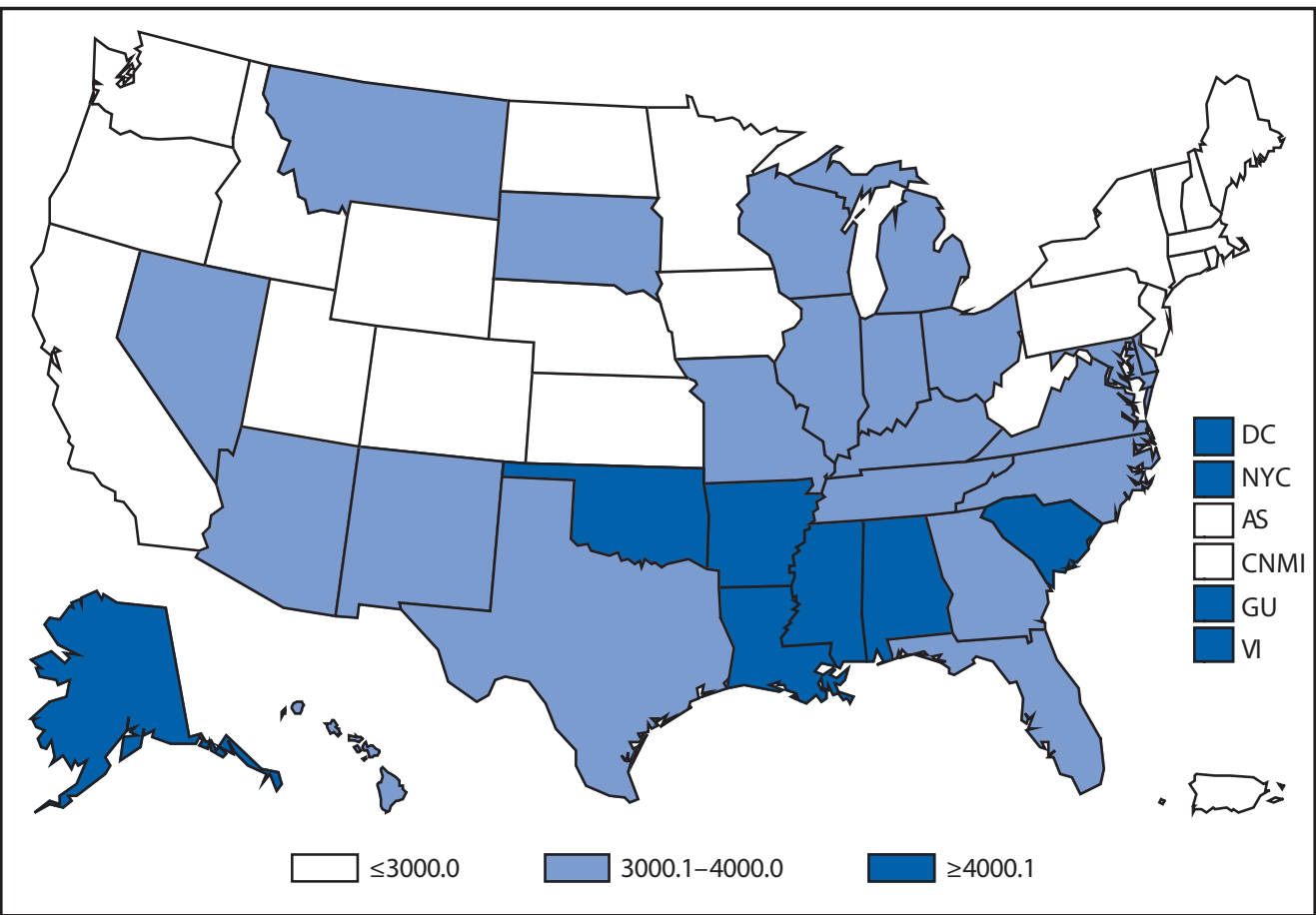

* Per 100,000 population.

Among women aged 15-24 years, the population targeted for chlamydia screening, the overall rate of reported cases of chlamydia was 3,305.2 per 100,000 females. Rates varied by state, with the highest reported rates in the South. 
CHOLERA. Number of reported cases — United States and U.S. territories, 2014

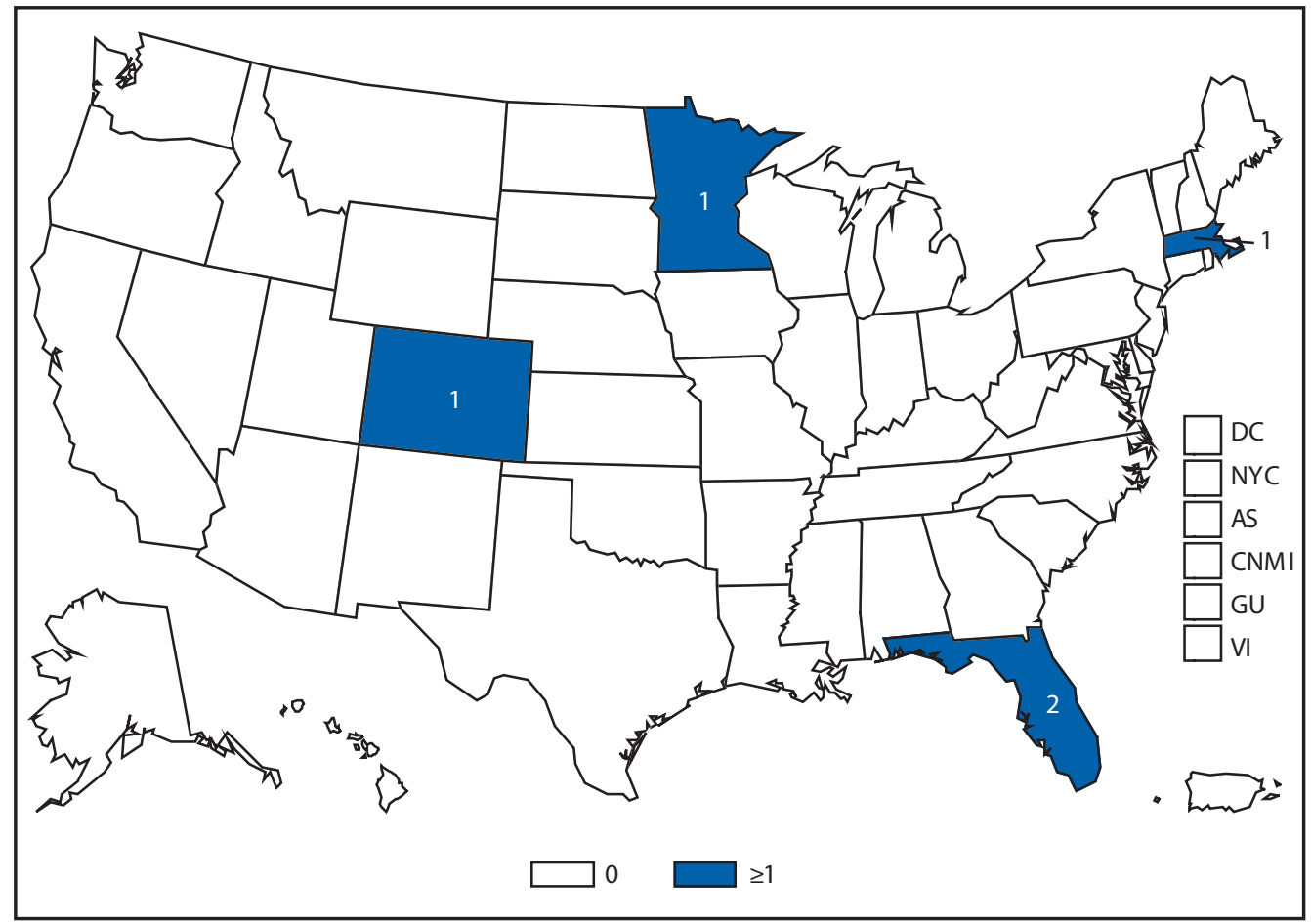

In 2014, five travel-associated cases of cholera were reported from four states. 
COCCIDIOIDOMYCOSIS. Number of reported cases — United States and U.S. territories, 2014

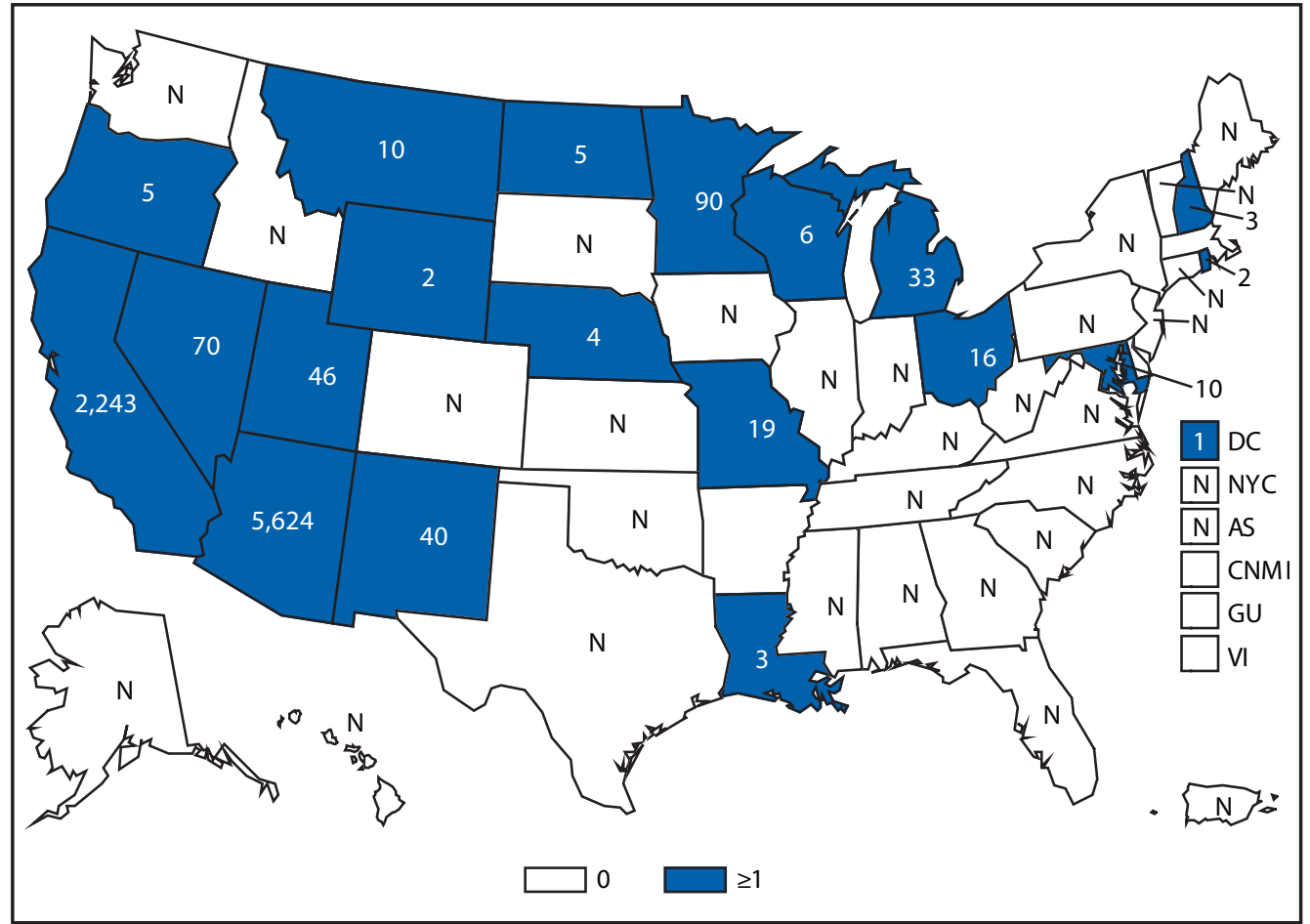

Abbreviation: $\mathrm{N}=$ not reportable.

In the United States, coccidioidomycosis is endemic in Southwestern states. However, the fungus that causes coccidioidomycosis also was recently found in south-central Washington. Cases reported from states outside the endemic area usually occur among travelers returning from areas in which the disease is endemic. 
CRYPTOSPORIDIOSIS. Incidence* of reported cases, by year — United States, 2003-2014

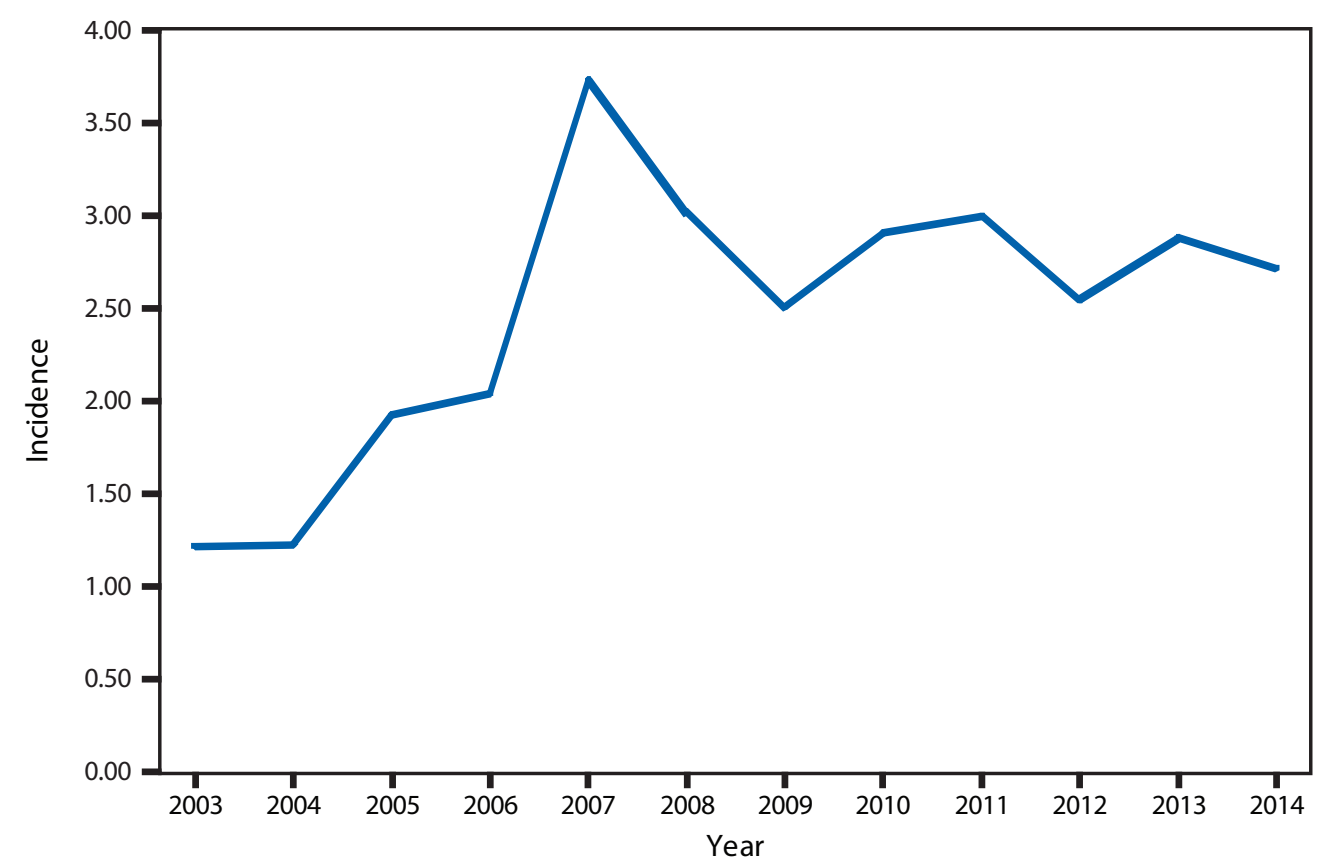

* Per 100,000 population.

The incidence of reported cryptosporidiosis after 2007 remains elevated ( $>2.5$ cases per 100,000 population) relative to the baseline observed before $2005(<1.5)$. Whether this increase reflects a change in the true incidence of cryptosporidiosis or changing diagnosis, testing, or reporting patterns is unclear. 


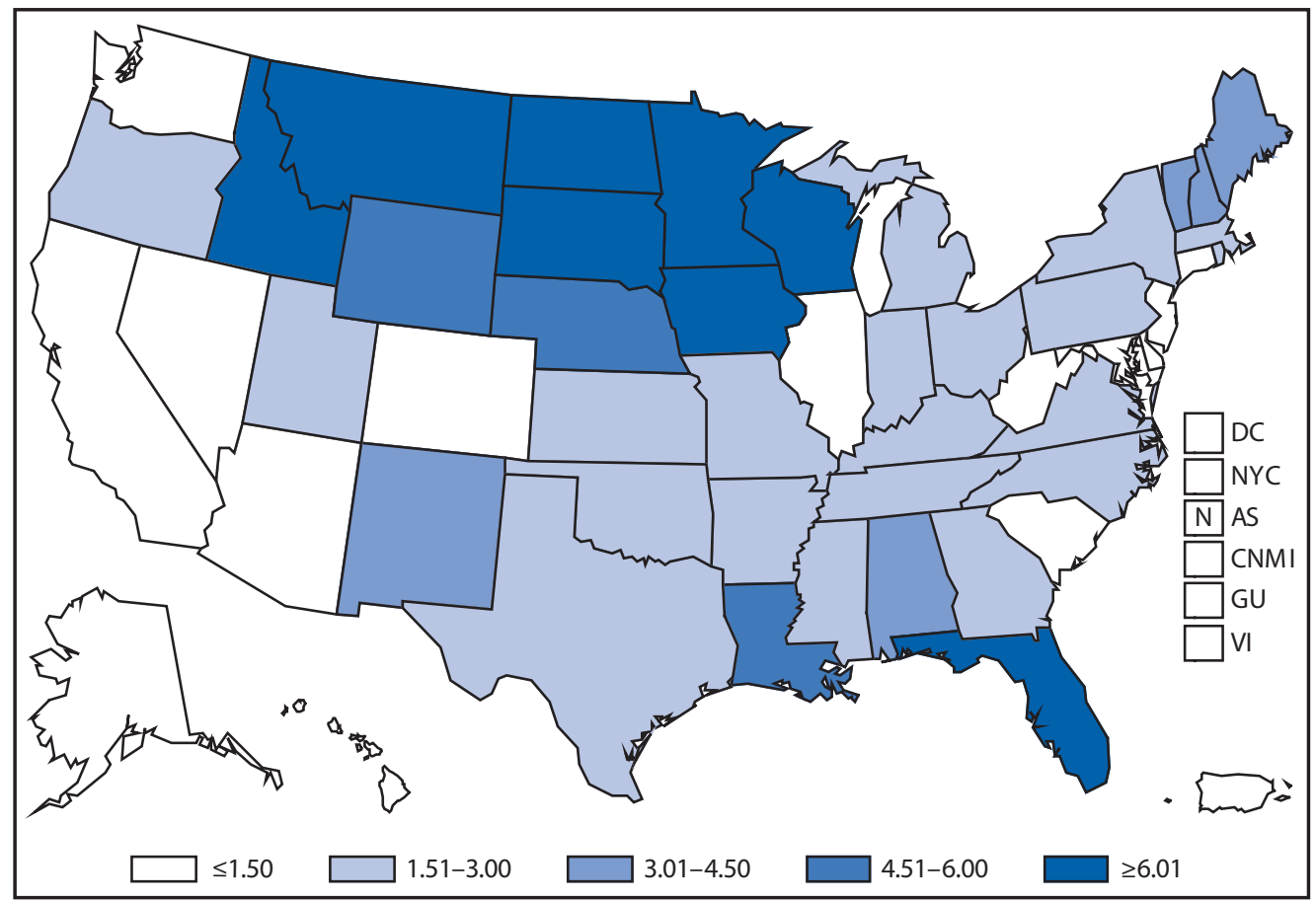

Abbreviation: $\mathrm{N}=$ not reportable.

* Per 100,000 population.

Cryptosporidiosis is widespread geographically in the United States. Although incidence appears to be consistently higher in certain states, differences in reported incidence among states might reflect differences in risk factors; the number of cases associated with outbreaks; or the capacity to detect, investigate, and report cases. 


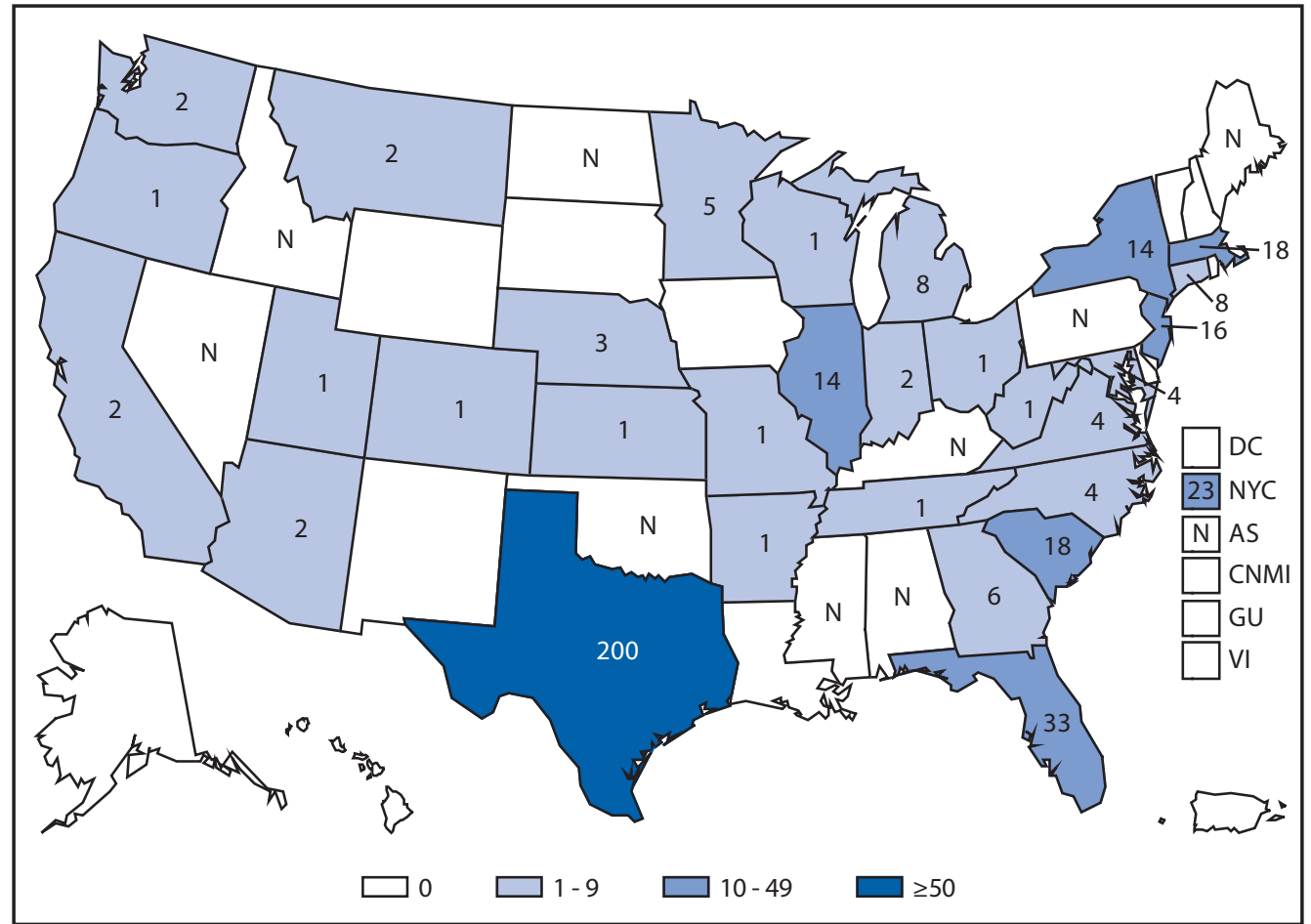

Abbreviation: $\mathrm{N}=$ not reportable.

In 2014, a total of 398 cases ( 356 confirmed and 42 probable) were reported from 30 states and New York City. Of these, 275 (69\%) were domestically acquired (i.e., they occurred in persons with no known history of travel outside the United States and Canada during the 14-day incubation period), at least 244 (89\%) of which occurred in persons with onset of illness during May-August. A vehicle of infection (fresh cilantro from Mexico) was identified for 26 cluster-associated cases in Texas. 
DENGUE VIRUS INFECTION. Number* of reported cases, by age group — United States, 2014

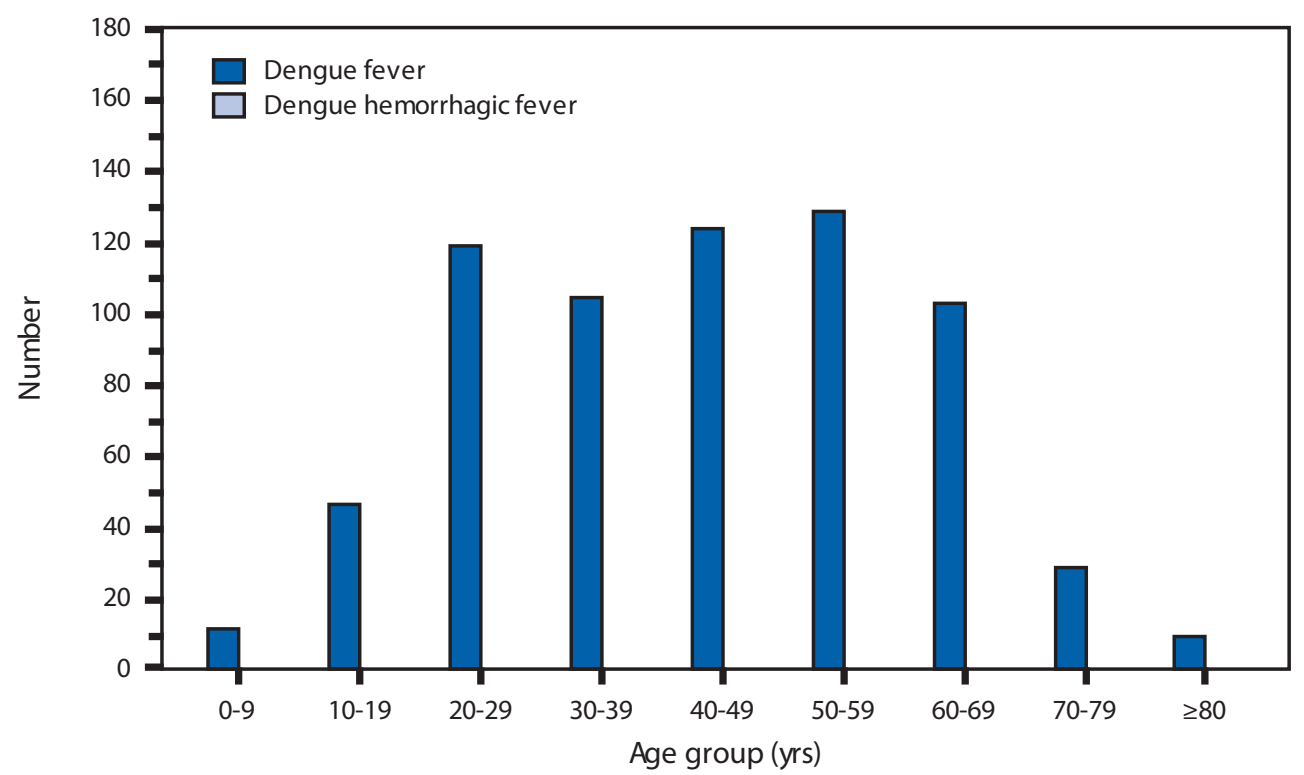

* Data from the Division of Vector-Borne Diseases, National Center for Emerging and Zoonotic Infectious Diseases (ArboNET Surveillance). Three age unknown cases of dengue fever. No cases of dengue hemorrhagic fever were reported in 2014 in travelers or residents of U.S. territories.

All age groups were affected by dengue. 
DENGUE FEVER AND DENGUE HEMORRHAGIC FEVER. Number* of reported cases, by location of residence - United States and U.S. territories, 2014

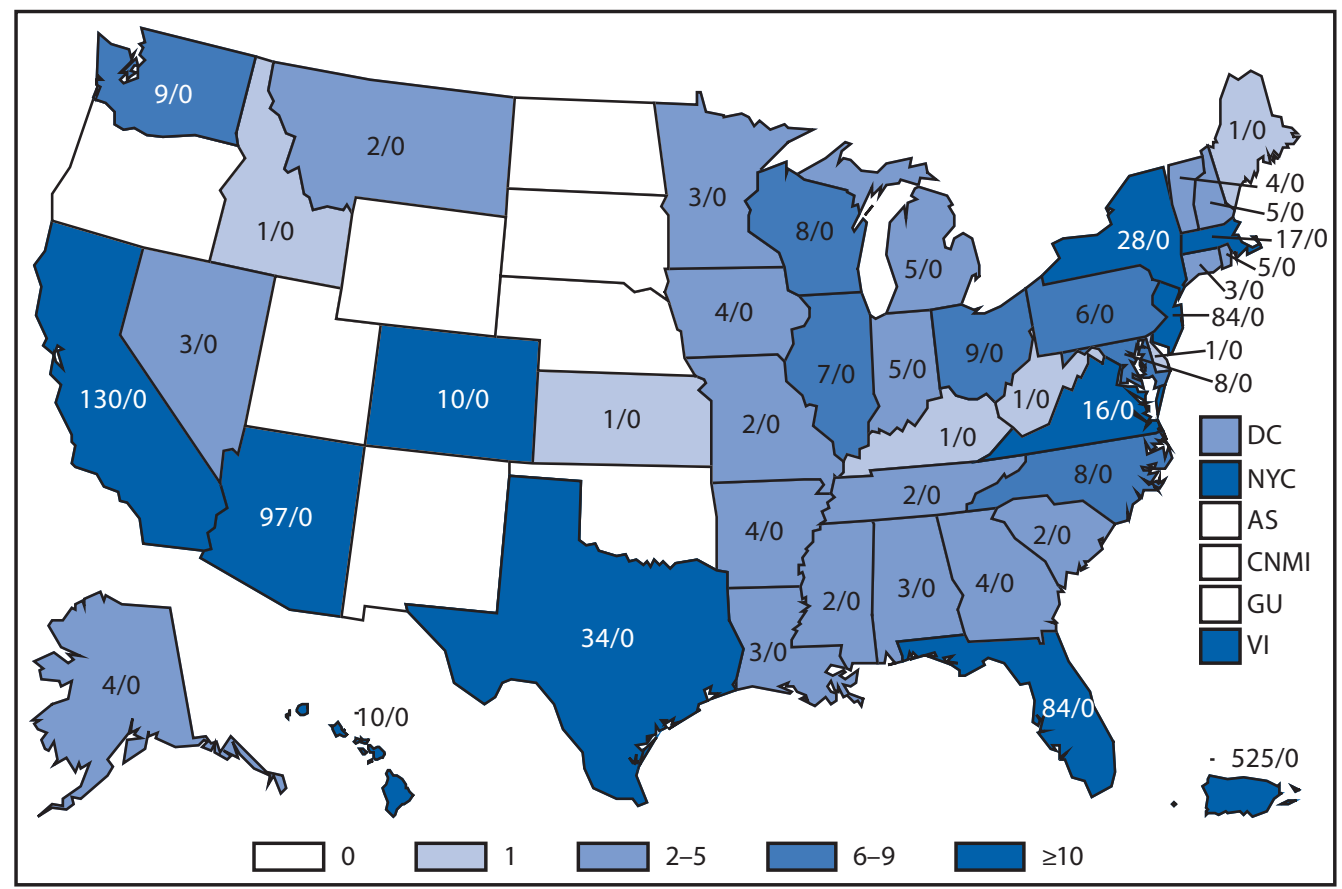

* Number of dengue fever cases/dengue hemorrhagic fever cases. Data from the Division of Vector-Borne Diseases, National Center for Emerging and Zoonotic Infectious Diseases (ArboNET Surveillance). The District of Columbia reported 2/0 cases, New York City 42/0, and U.S. Virgin Islands 19/0.

California, New Jersey, and Arizona reported the most dengue cases. No cases of dengue hemorrhagic fever were reported in 2014 in travelers or residents of U.S. states and territories. 
DIPHTHERIA. Number of reported cases, by year — United States, 1984-2014

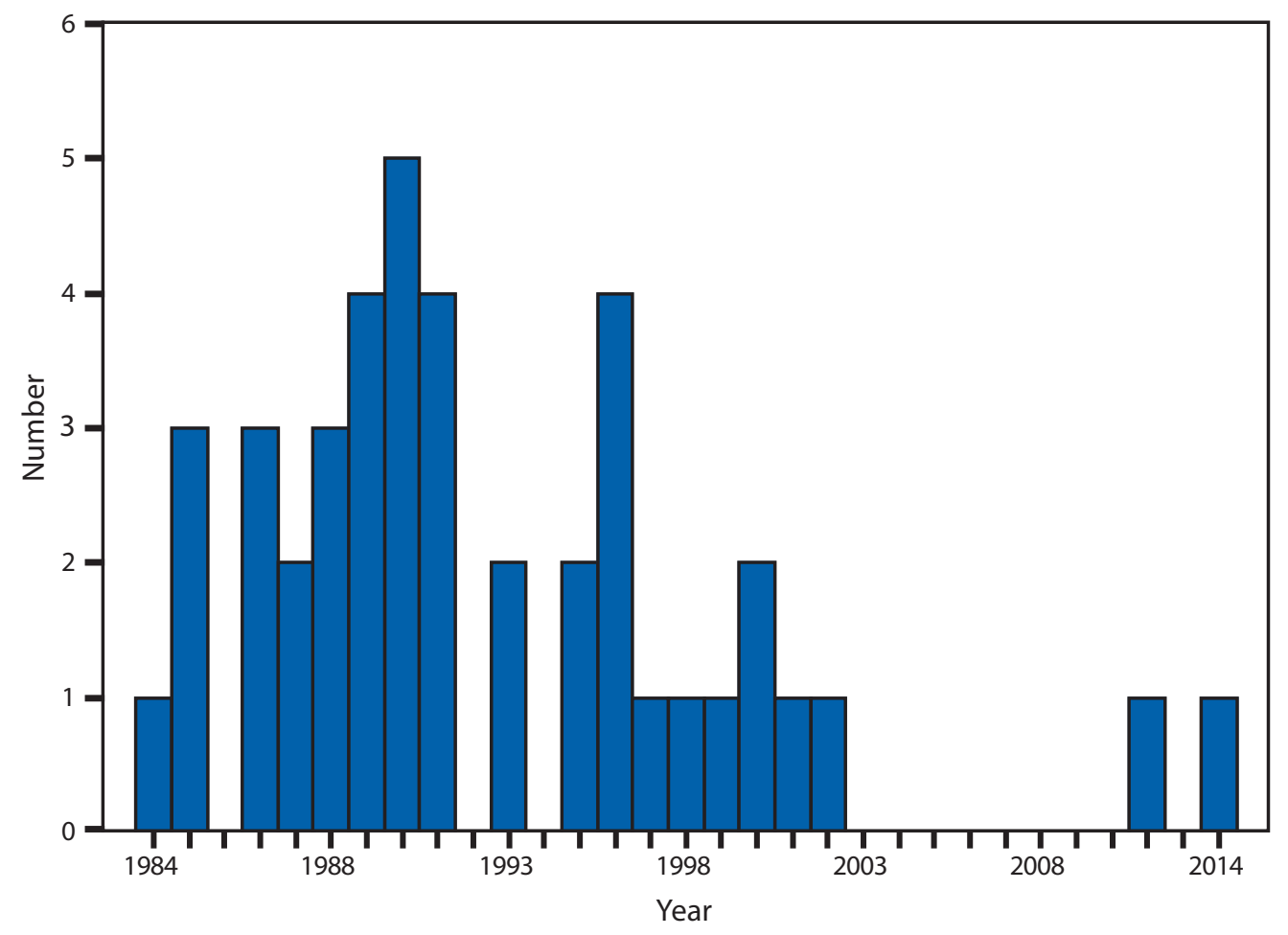

Reported diphtheria is rare in the United States; no more than one case per year has been reported since 2003. 
EHRLICHIOSIS AND ANAPLASMOSIS, ANAPLASMA PHAGOCYTOPHILUM. Number of reported cases, by county - United States, 2014

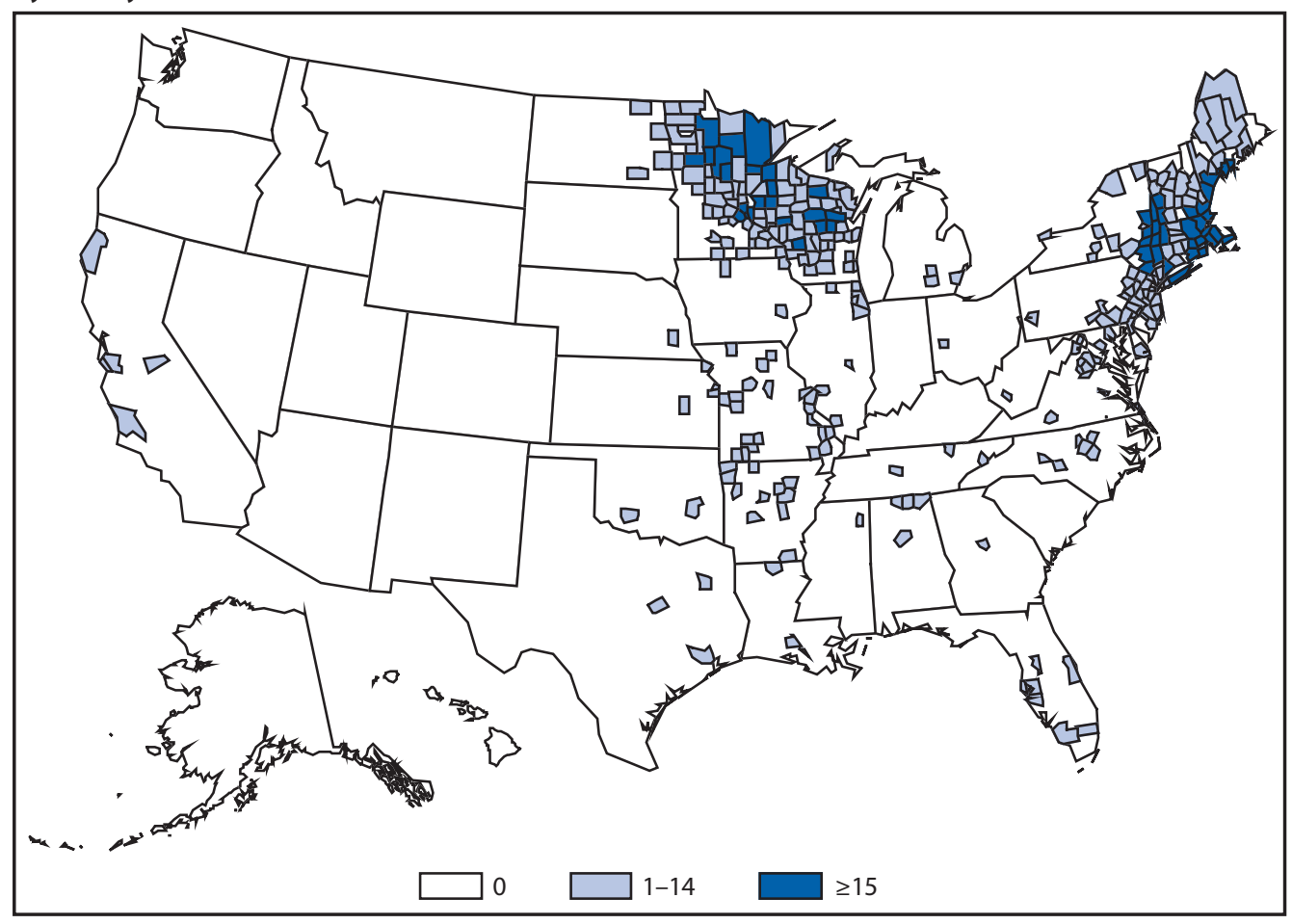

Cases are reported primarily from the Upper Midwest and coastal New England, reflecting both the range of the primary tick vector species, Ixodes scapularis, which is also known to transmit Lyme disease and babesiosis, and the range of preferred animal hosts for tick feeding. 
EHRLICHIOSIS AND ANAPLASMOSIS, EHRLICHIA CHAFFEENSIS. Number of reported cases, by county United States, 2014

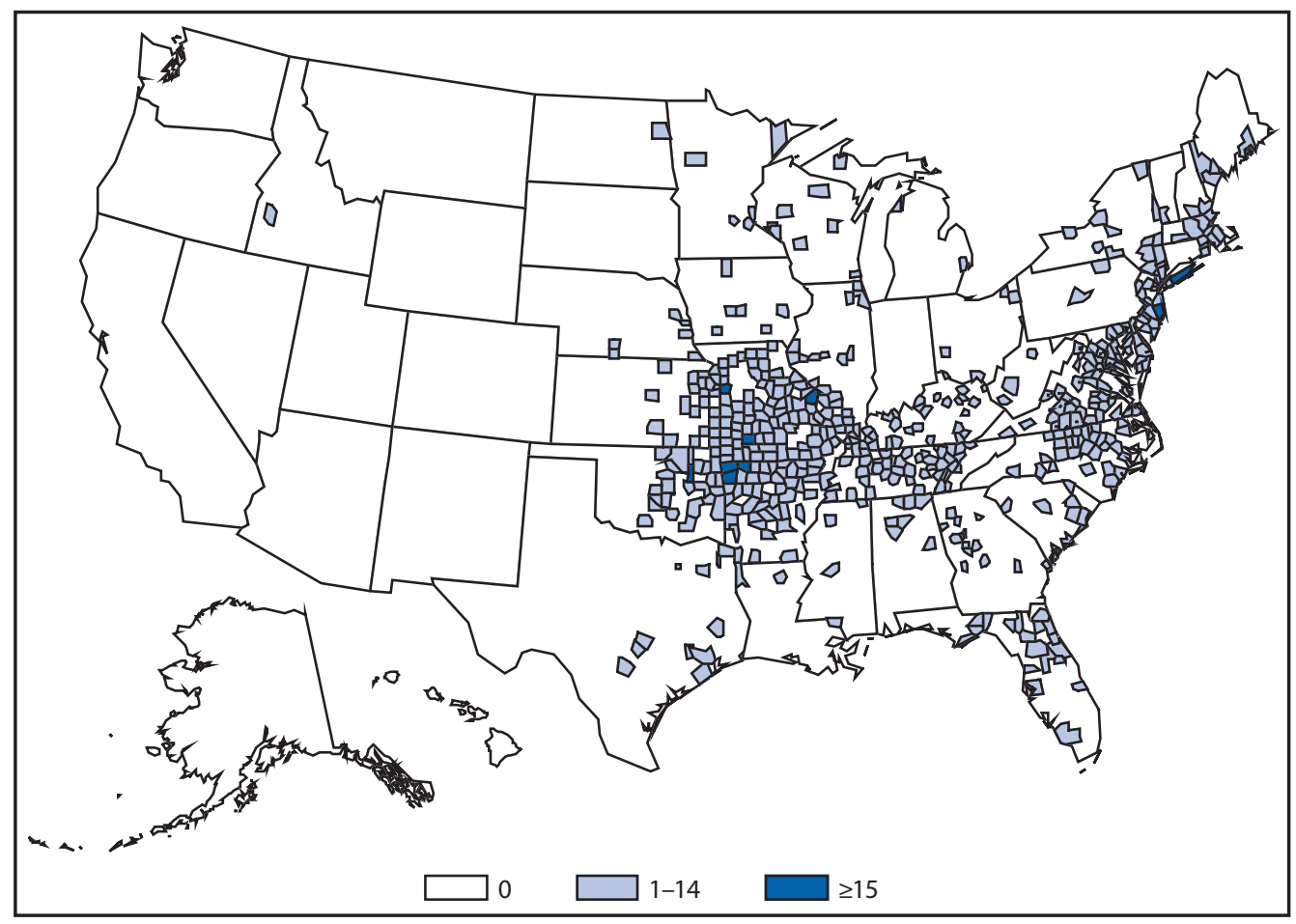

Ehrlichia chaffeensis is the most common type of ehrlichiosis infection in the United States. This tickborne pathogen is transmitted by Amblyomma americanum, the lone star tick, whose geographic range extends from the Southeast into parts of the Northeast and Midwest. The majority of cases of $E$. chaffeensis ehrlichiosis are reported from the Midwest, South, and Northeast regions. 
EHRLICHIOSIS AND ANAPLASMOSIS, EHRLICHIA EWINGII. Number of reported cases, by county United States, 2014

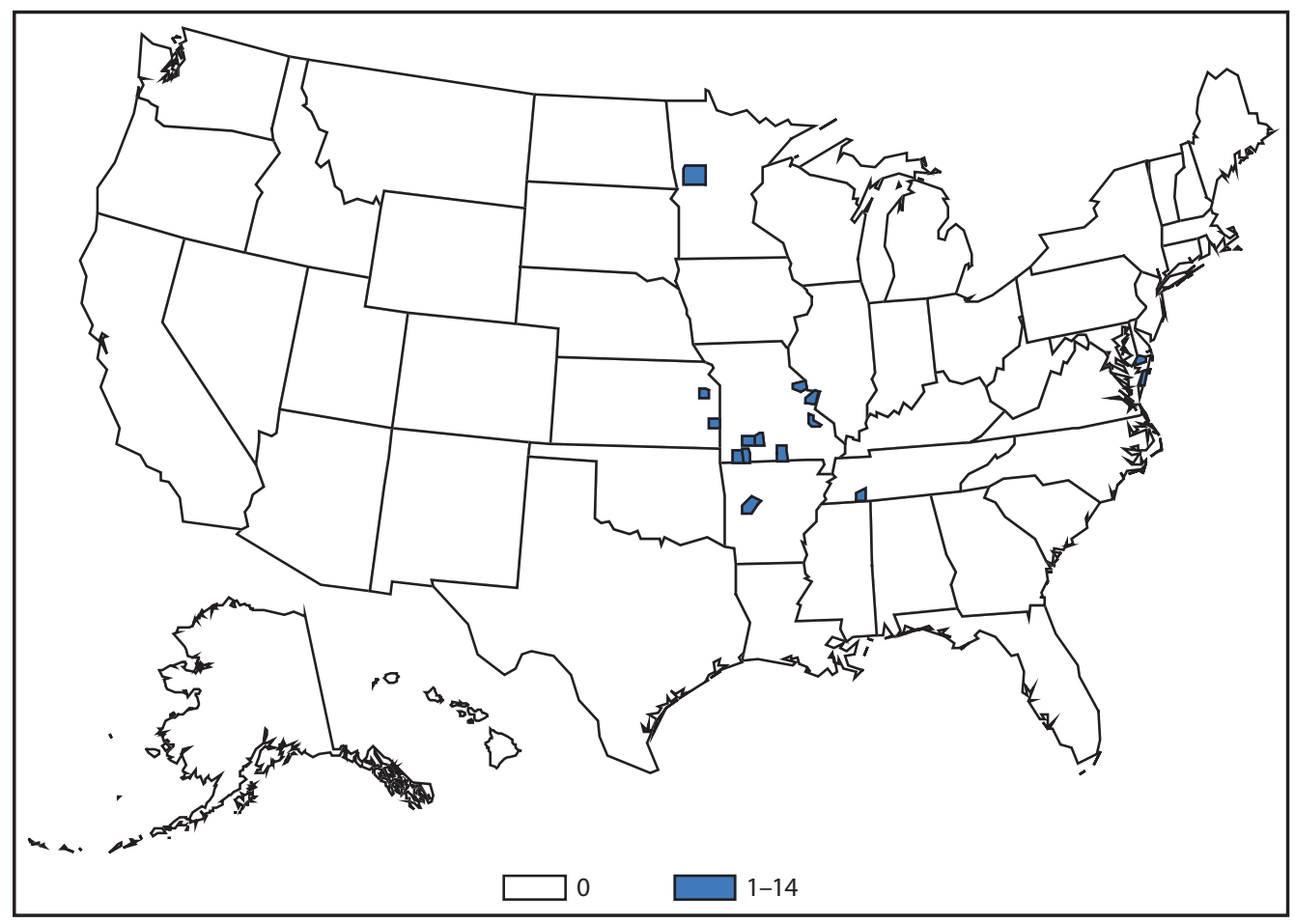

Ehrlichia ewingii is the least common cause of ehrlichiosis. Ehrlichia ewingii is carried by Amblyomma americanum, the tick, which is the same vector that transmits $E$. chaffeensis and whose geographic range extends from the Southeast into parts of the Northeast and Midwest. No serologic tests are used to distinguish between the two species, and differentiation can only be made by molecular genotyping. 
EHRLICHIOSIS AND ANAPLASMOSIS, UNDETERMINED. Number of reported cases, by county United States, 2014

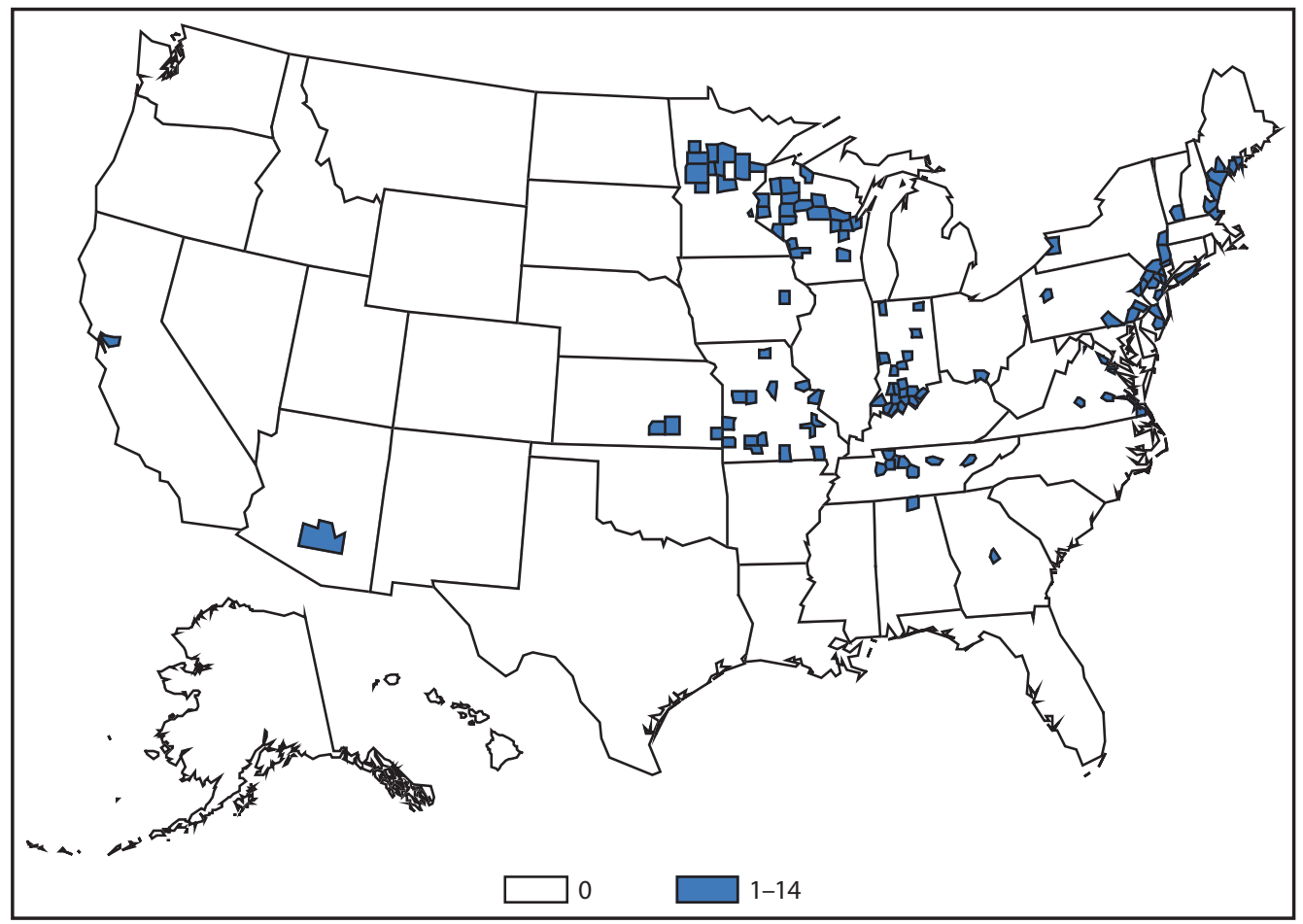

Cases of ehrlichiosis and anaplasmosis caused by an undetermined species are reported across the United States but are more likely to be reported in the Midwest region and the Middle Atlantic division. This classification of "undetermined" is most often used in areas where no clear geographic boundary separates the individual tick vectors. In the Upper Midwest, some cases are likely caused by Ehrlichia muris-like agent, a recognized cause of ehrlichiosis in the United States. Because ehrlichiosis and anaplasmosis elicit some cross reactivity in antibody detection, this category can also be used when single, inappropriate diagnostic tests are performed that do not provide differentiation of etiology. 
GIARDIASIS. Incidence* of reported cases, by year — United States, 2003-2014

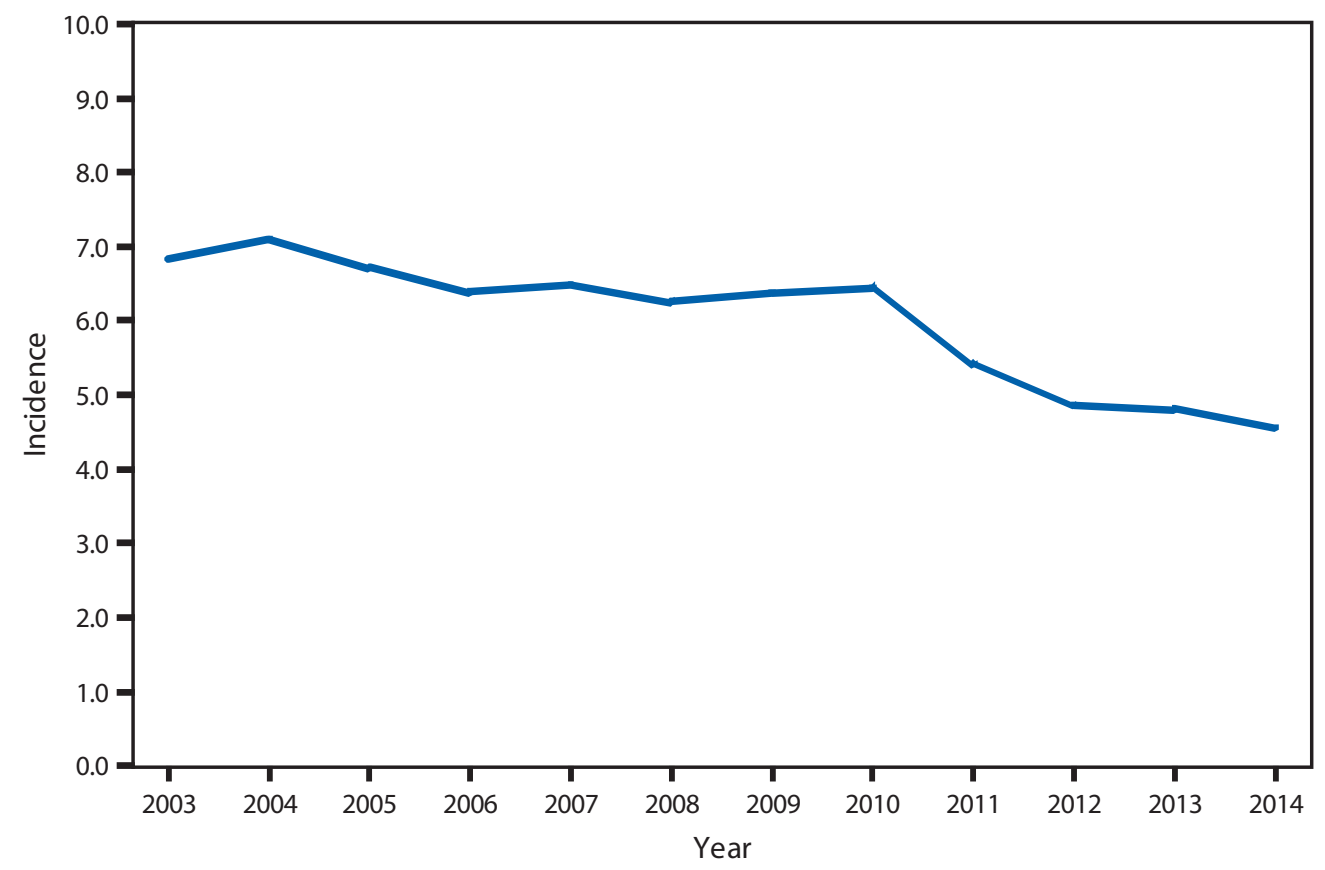

* Per 100,000 population.

The incidence of giardiasis decreased in 2014, continuing a general decrease that began in 2011 following several years of stable reporting. Factors contributing to this decrease might include a decrease in disease transmission, changes in case definition, or changes in surveillance priorities in some states. 
GONORRHEA. Incidence* of reported cases — United States and U.S. territories, 2014

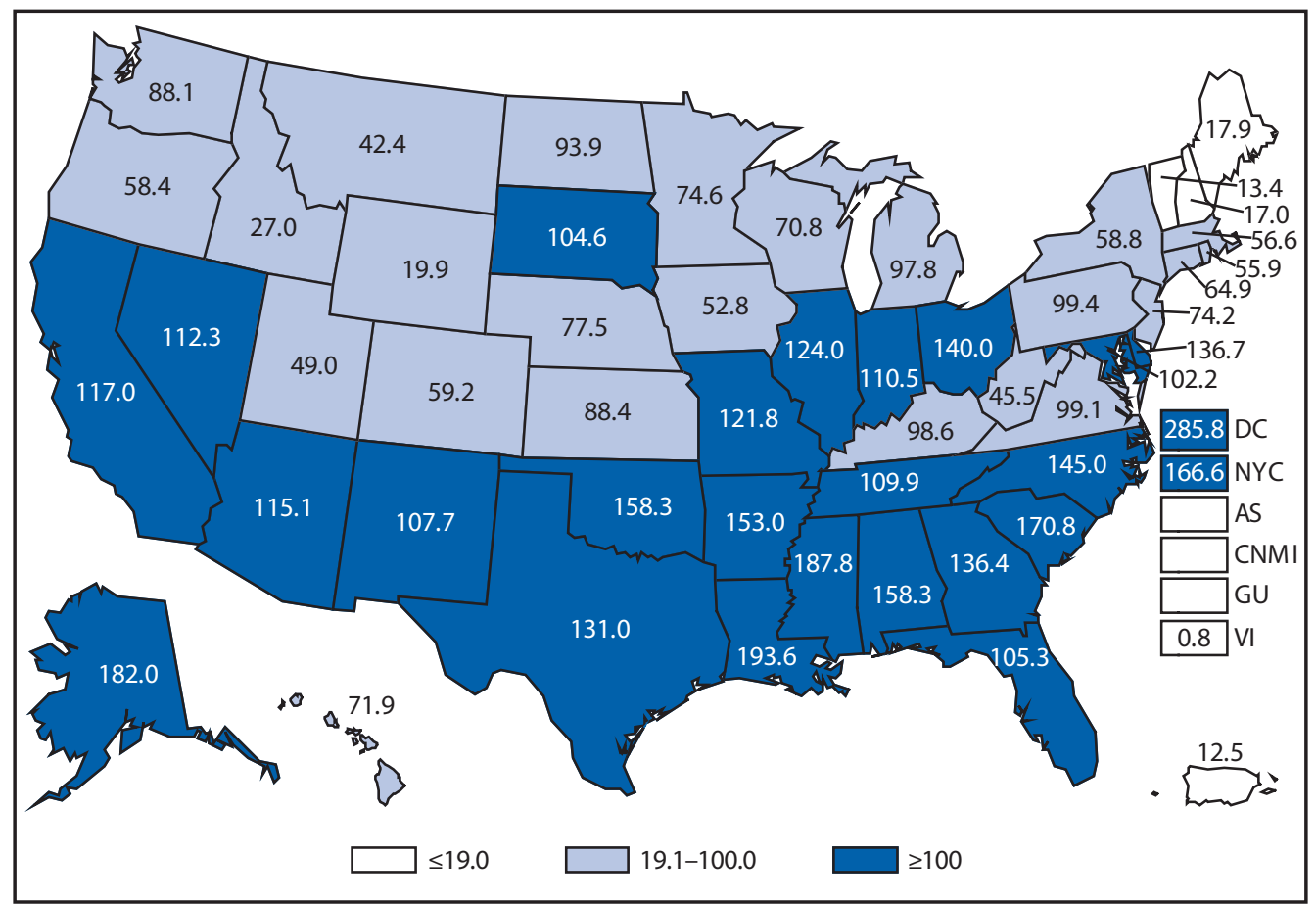

* Per 100,000 population.

In 2014, rates of reported gonorrhea cases per 100,000 population ranged by state from 13.4 in Vermont to 193.6 in Louisiana; the gonorrhea rate in the District of Columbia was 285.8. 
GONORRHEA. Incidence* of reported cases, by sex — United States, 1994-2014

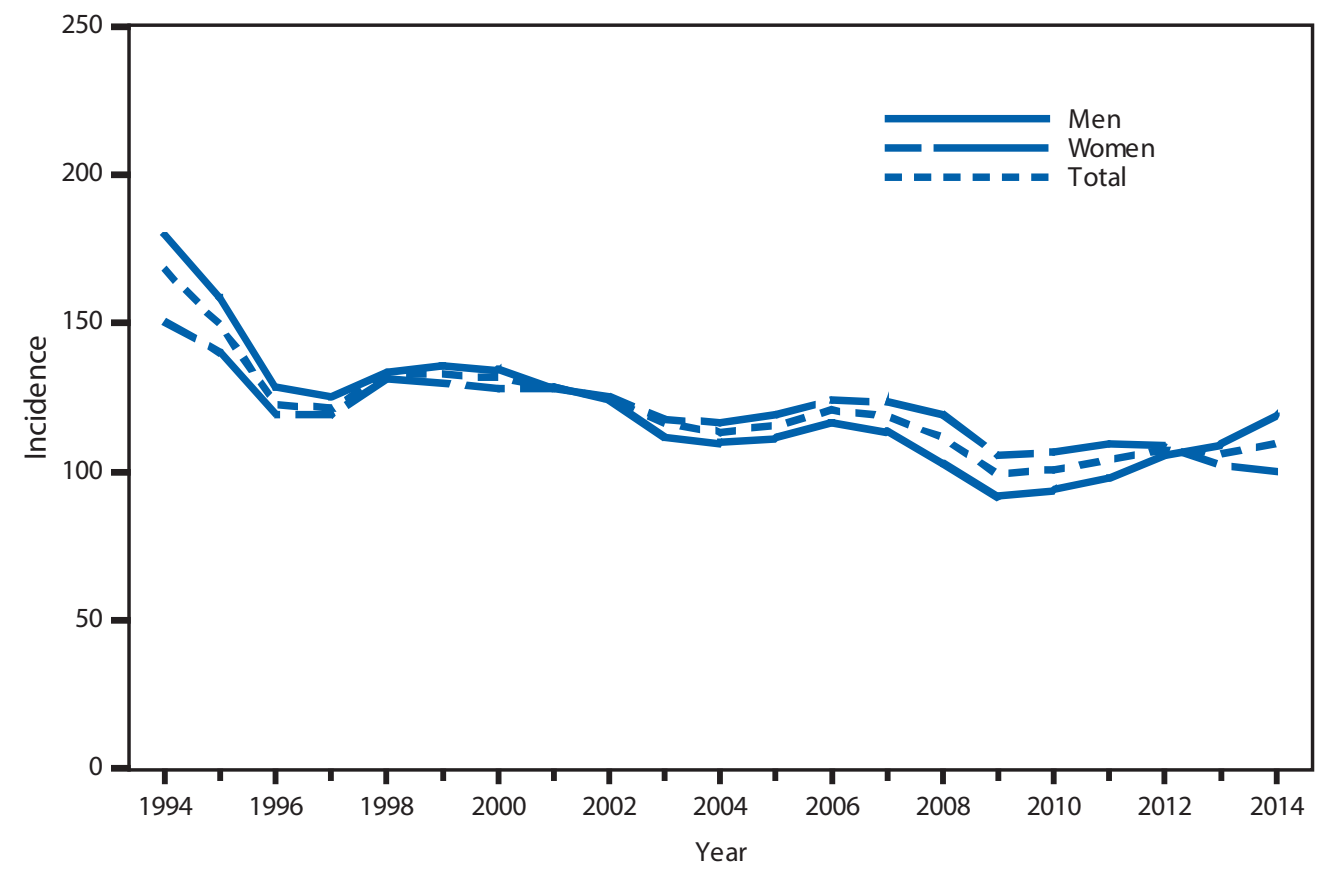

* Per 100,000 population.

Since 2013, the rate of reported cases of gonorrhea among men was higher than the rate among women. During 2010-2014, the rate among men increased from 94.1 to $119.1(26.5 \%)$ and the rate among women decreased from 106.5 to 100.4 (5.7\%). During 2013-2014, the rate among men increased from 109.5 to 119.1 $(8.8 \%)$ and the rate among women decreased from 102.4 to 100.4 (1.9\%). 
GONORRHEA. Incidence* of reported cases among women aged 15-24 years — United States and U.S. territories, 2014

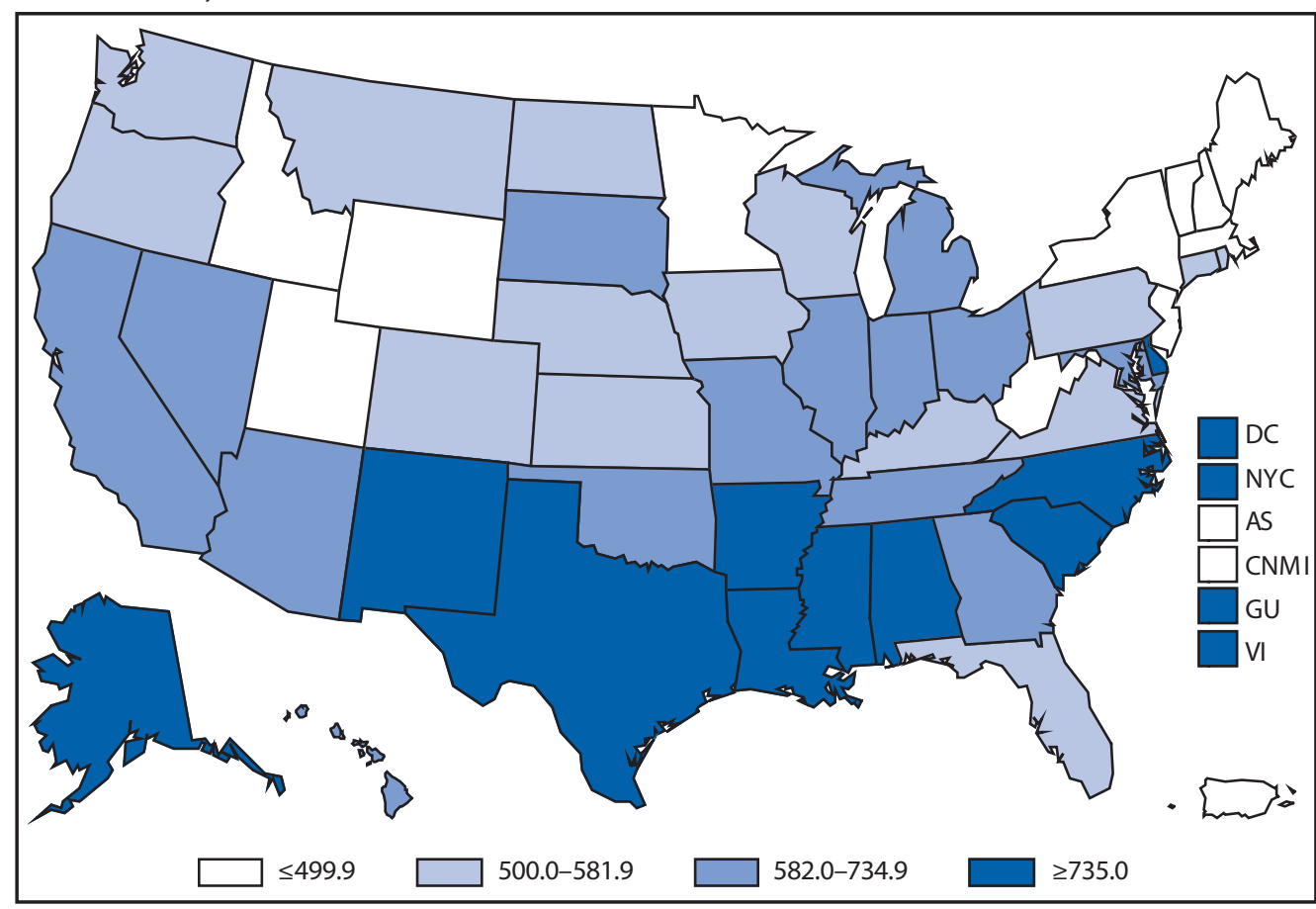

* Per 100,000 population.

In 2014, rates per 100,000 population of reported gonorrhea cases continued to be highest among adolescents and young adults. For women, the highest rates were observed among those aged 20-24 years (531.0) and $15-19$ years (431.7). 
HAEMOPHILUS INFLUENZAE, INVASIVE DISEASE. Incidence* of reported cases, by serotype among persons aged $<5$ years - United States, 2001-2014

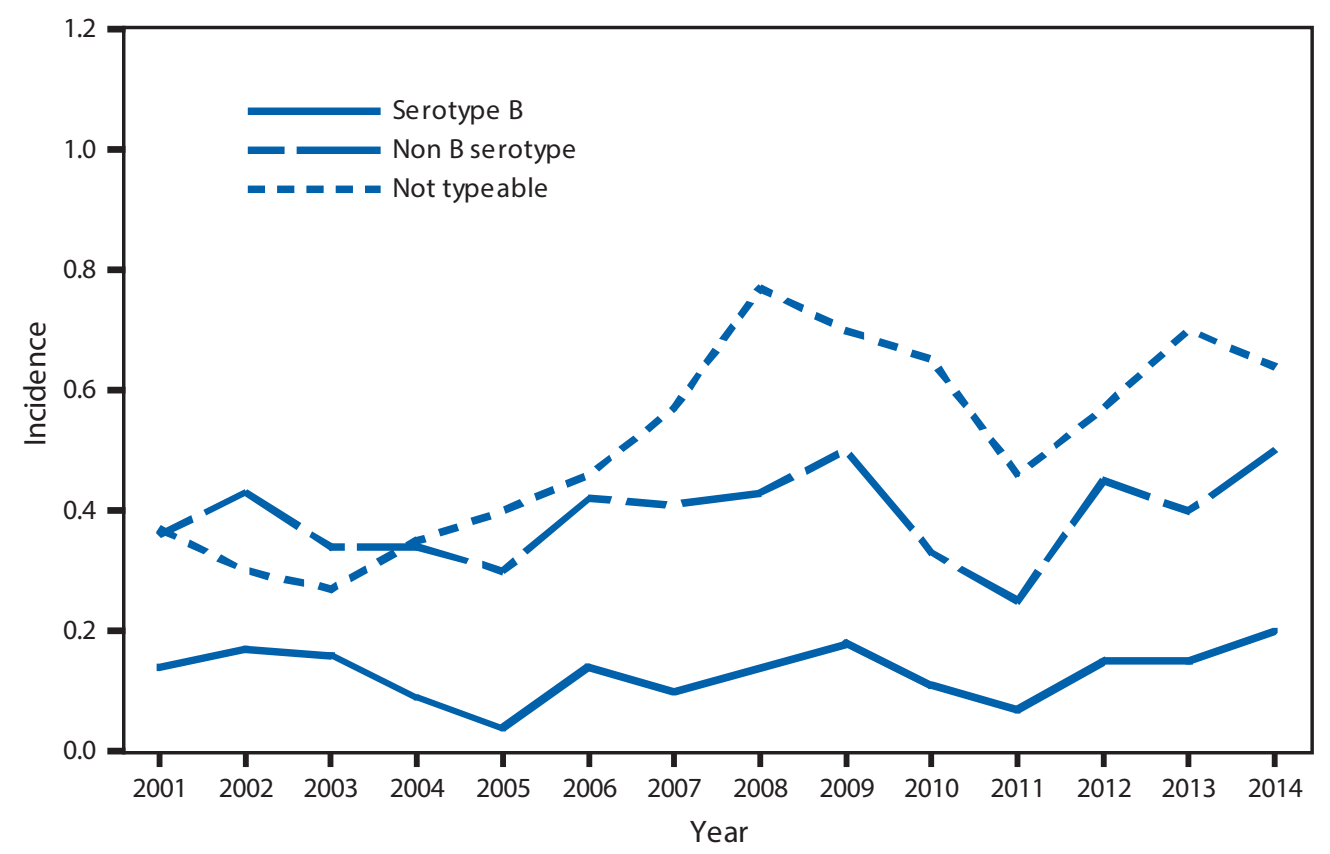

* Per 100,000 population.

Rates of all invasive Haemophilus influenzae disease remain low; the majority of invasive disease in children aged $<5$ years is caused by nontypeable Haemophilus influenzae. Haemophilus influenzae Type b incidence remains below the Healthy People 2020 goal of 0.27 per 100,000 population among those aged $<5$ years. 
HAEMOPHILUS INFLUENZAE, INVASIVE DISEASE. Incidence* of reported cases, by serotype among persons aged $\geq 5$ years — United States, 2001-2014

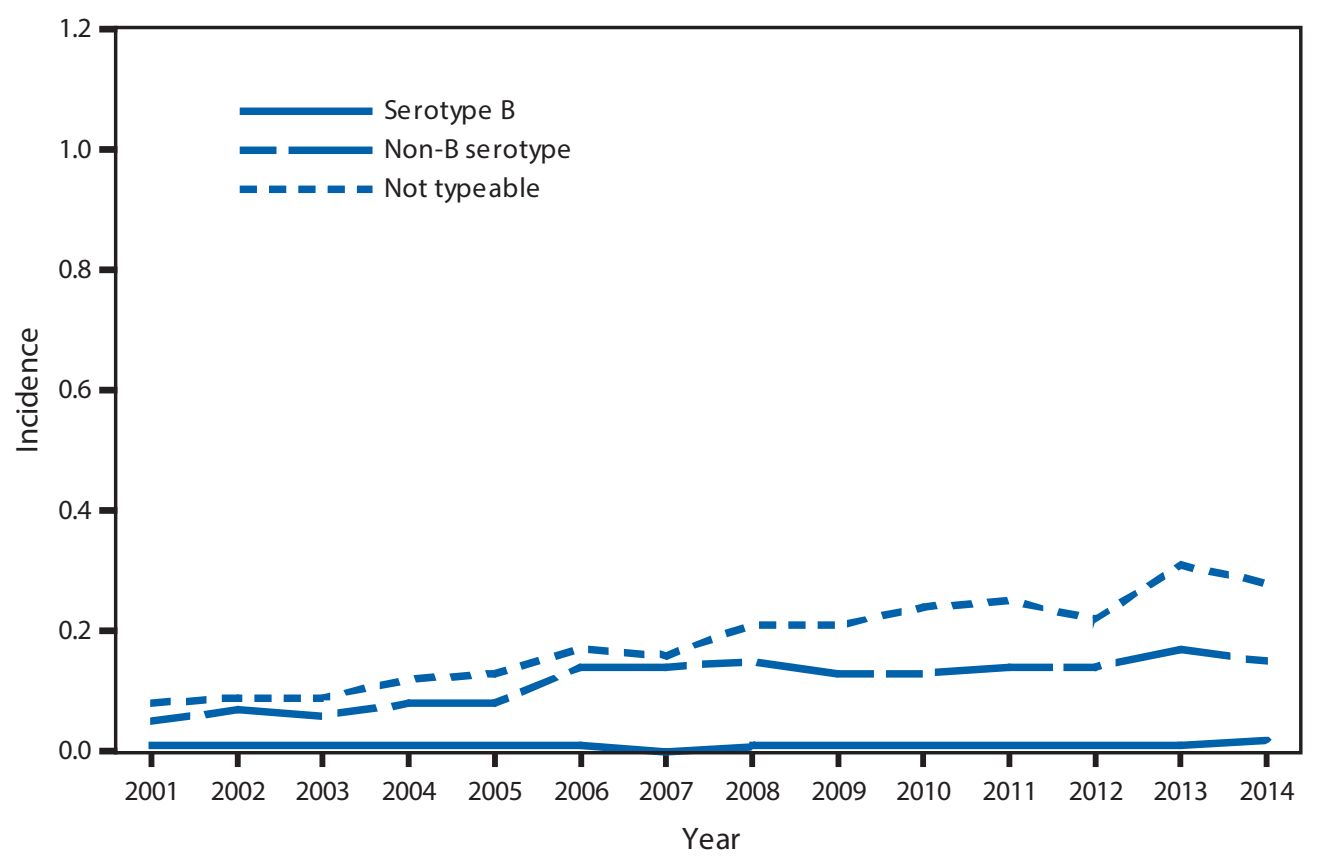

* Per 100,000 population.

Rates of all invasive Haemophilus influenzae disease remain low; the majority of invasive disease in persons aged $\geq 5$ years is caused by nontypeable Haemophilus influenzae. 
HANSEN'S DISEASE (LEPROSY). Number of reported cases, by year — United States, 1994-2014

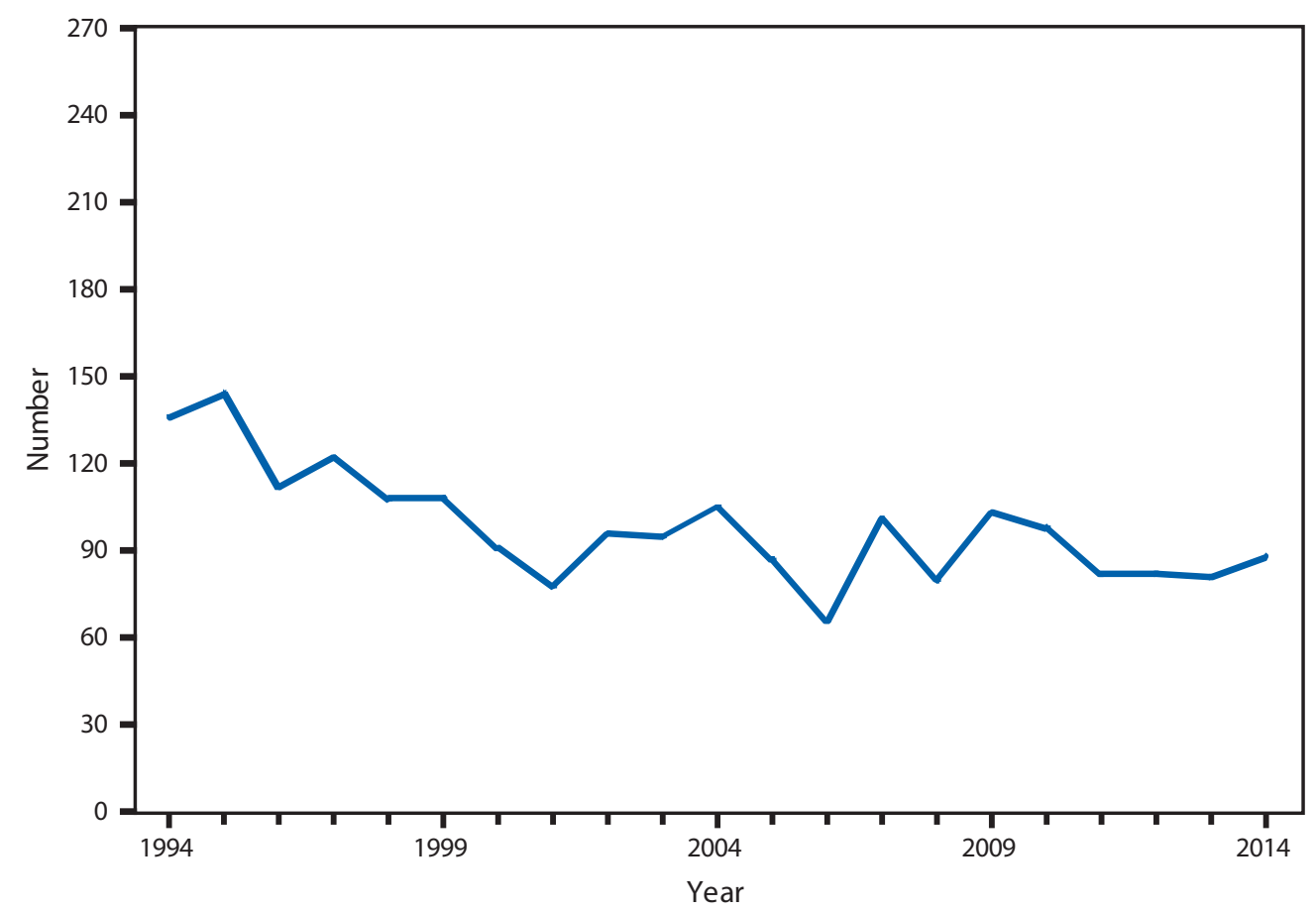

An annual average of 89 Hansen's disease cases have been reported since 2000, with a low of 66 in 2006 and a high of 105 in 2004. 
HEMOLYTIC UREMIC SYNDROME, POSTDIARRHEAL. Number of reported cases — United States and U.S. territories, 2014

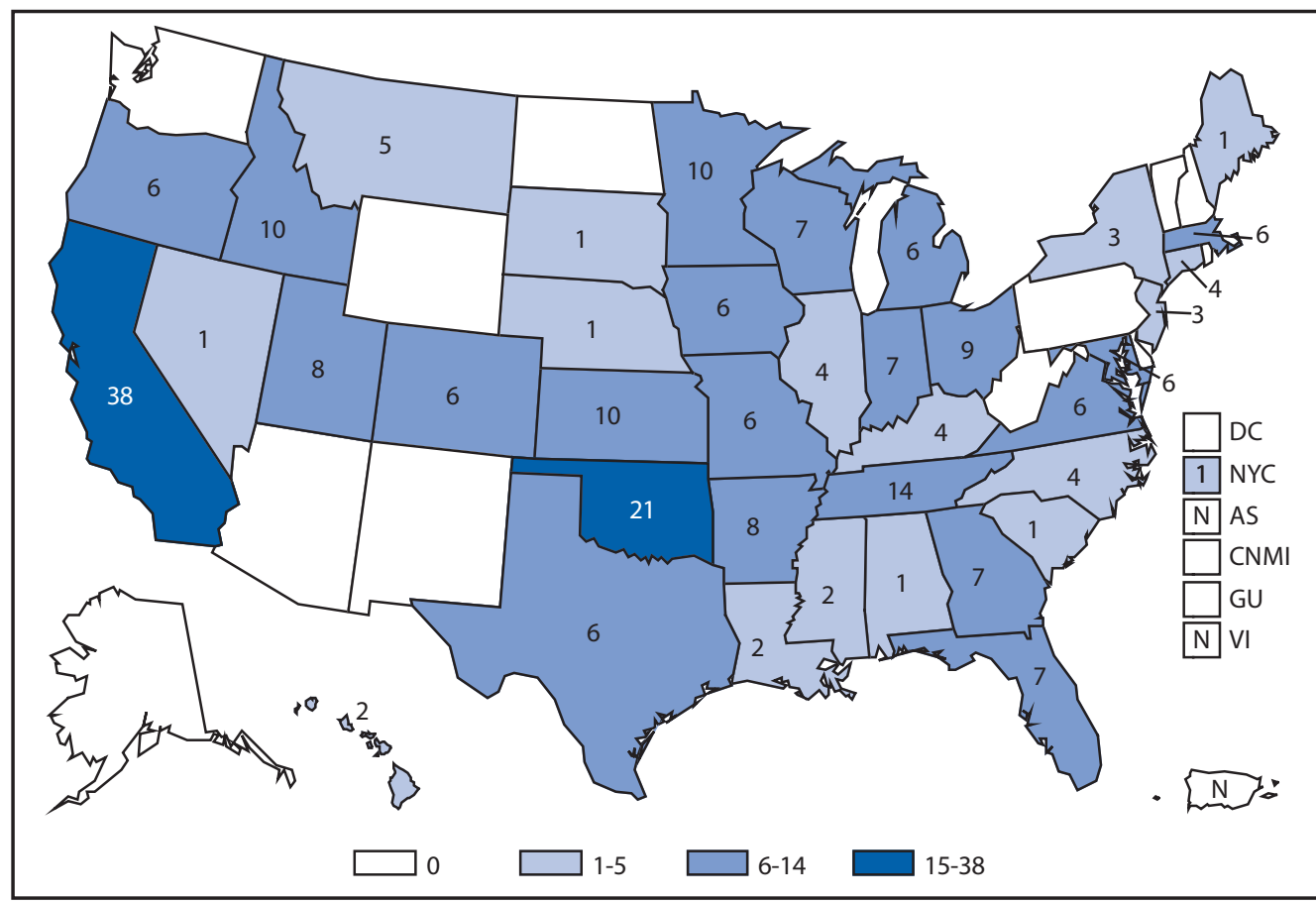

Abbreviation: $\mathrm{N}=$ not reportable.

In 2014, a total of 41 of 56 jurisdictions (states, districts, and territories) reported cases, and three jurisdictions did not report their data. Most cases of postdiarrheal hemolytic uremic syndrome are caused by Shiga toxin-producing Escherichia coli. 
HEPATITIS, ACUTE A. Incidence* of reported cases, by county — United States, 2014

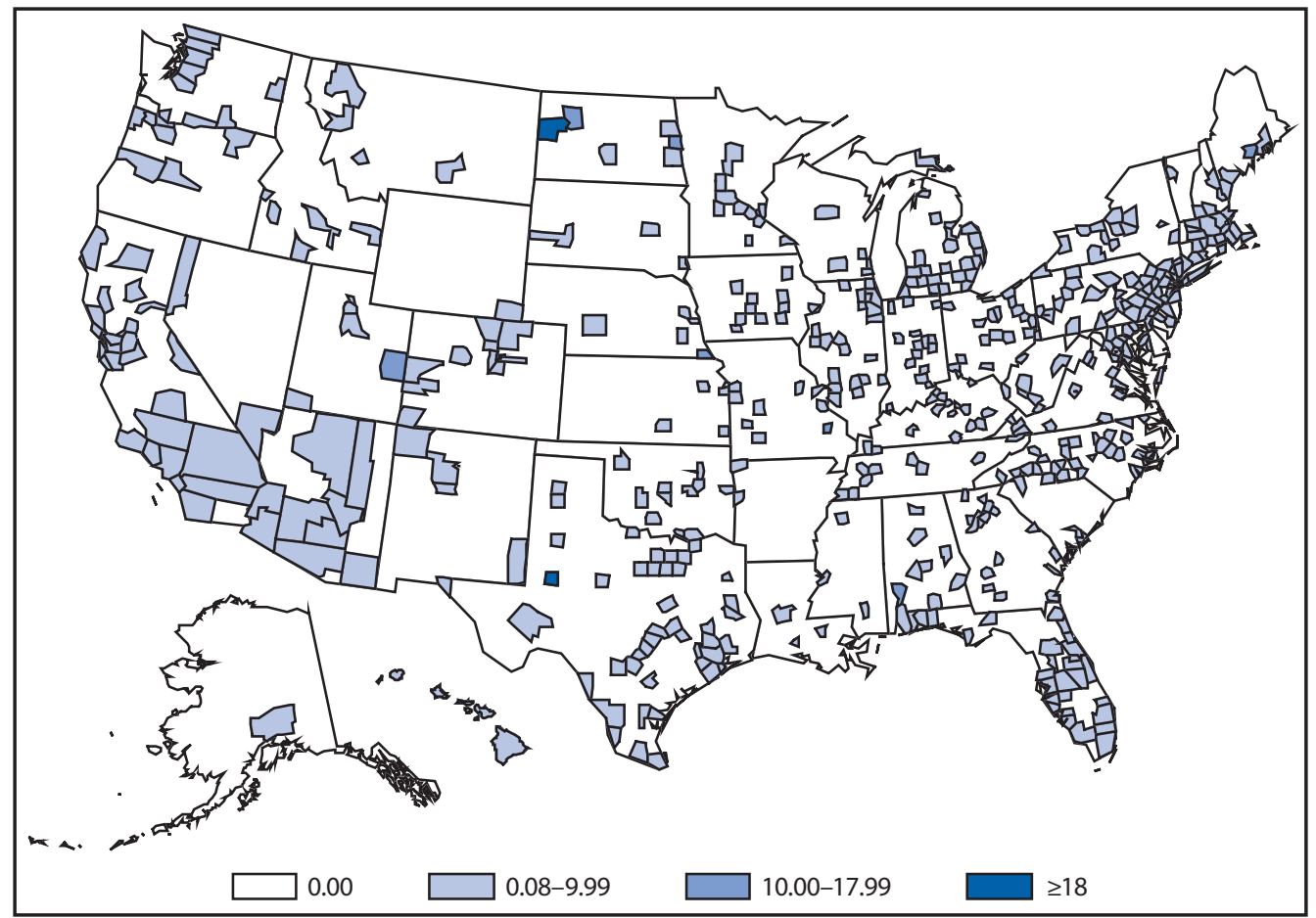

* Per 100,000 population.

Although effective vaccines to prevent Hepatitis A infections have been available in the United States since 1995, in 2014, at least one case occurred in each state. A total of 1,239 cases were reported, and nine counties in seven states reported incidence rates of $\geq 10$ cases per 100,000 population. 
HEPATITIS B, PERINATAL INFECTION. Number of reported cases — United States and U.S. territories, 2014

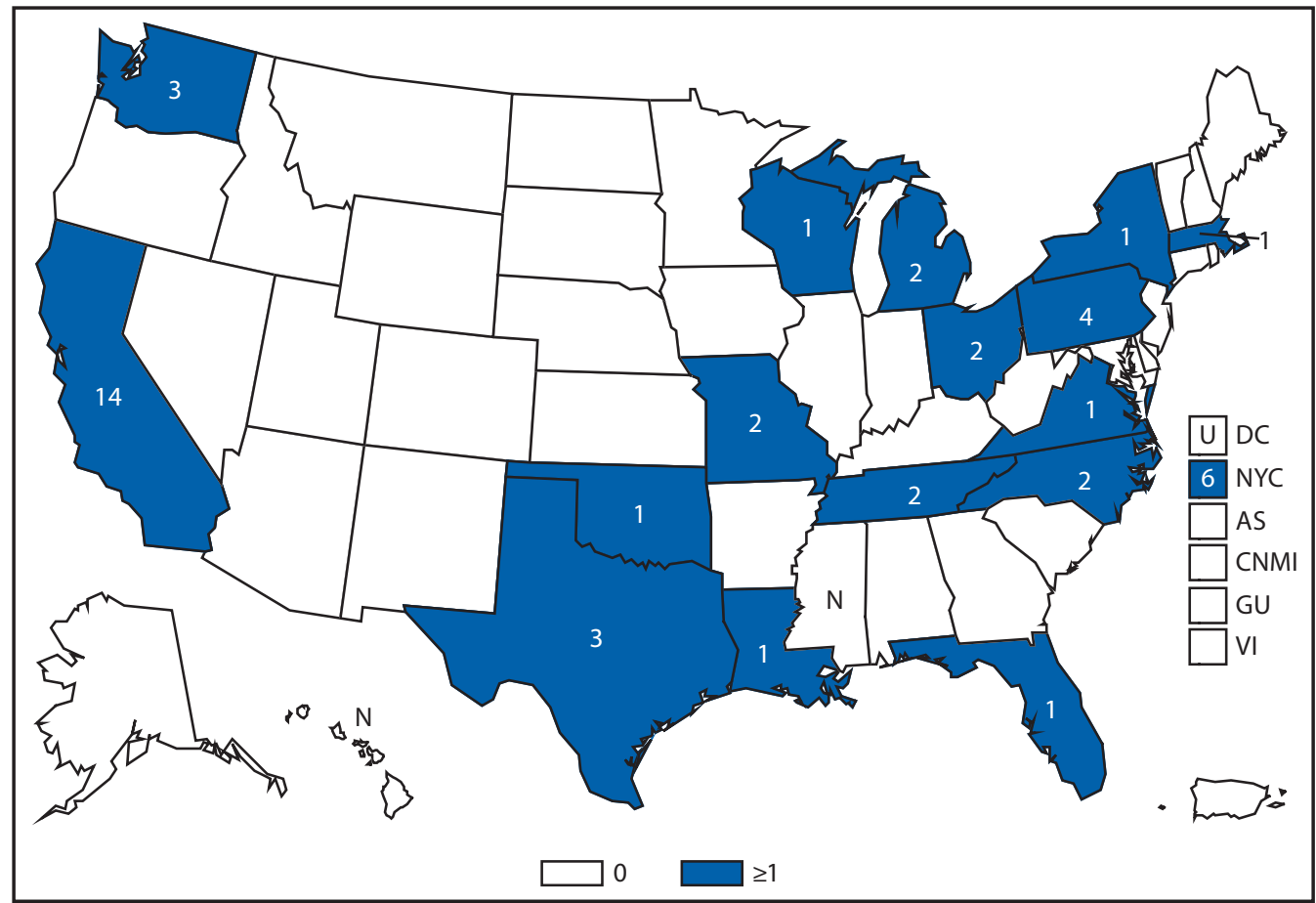

Abbreviations: $\mathrm{N}=$ not reportable; $\mathrm{U}=$ data not available.

In 2014, a total of 16 states reported 47 cases of perinatal hepatitis B. Because of the asymptomatic nature of hepatitis $B(\mathrm{HBV})$ in young children, lack of timely testing among exposed infants, and incomplete reporting of infants with hepatitis $B$, the reported number of cases of perinatal hepatitis $B$ is considered low and probably represents only a fraction of all infants infected with HBV at birth. 
Morbidity and Mortality Weekly Report

HEPATITIS, ACUTE C. Number of of reported cases, by year — United States, 2000-2014

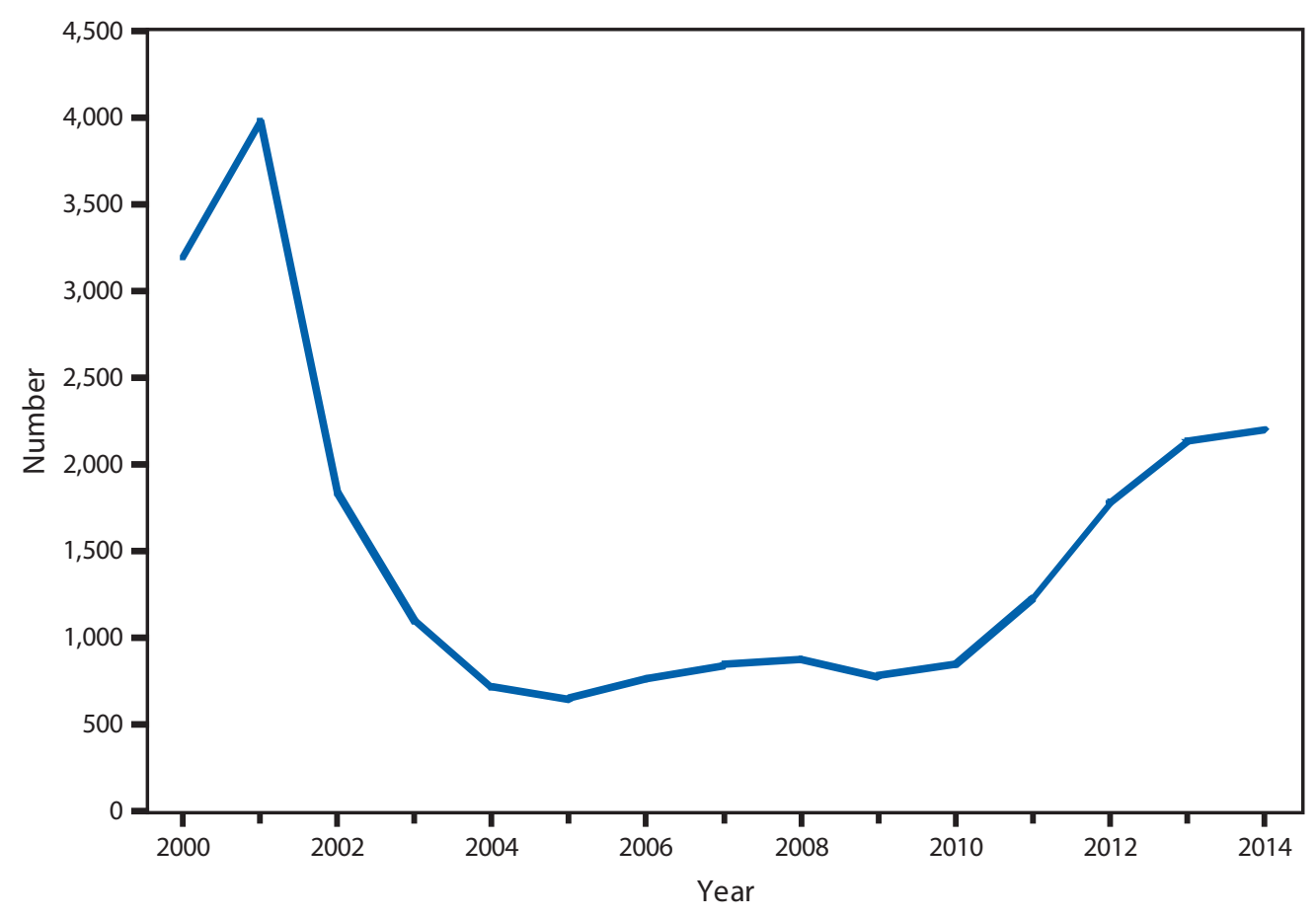

After declining during 2000-2005, then remaining stable at approximately 800-1000 reported cases per year until 2010, reported acute hepatitis C cases doubled during 2011-2014. The rate of increase has slowed, and the number of cases were reported in $2014(2,204)$ and $2013(2,154)$ remained stable. 
HUMAN IMMUNODEFICIENCY VIRUS DIAGNOSES. Percentage of diagnosed cases, by race/ethnicity United States, 2014

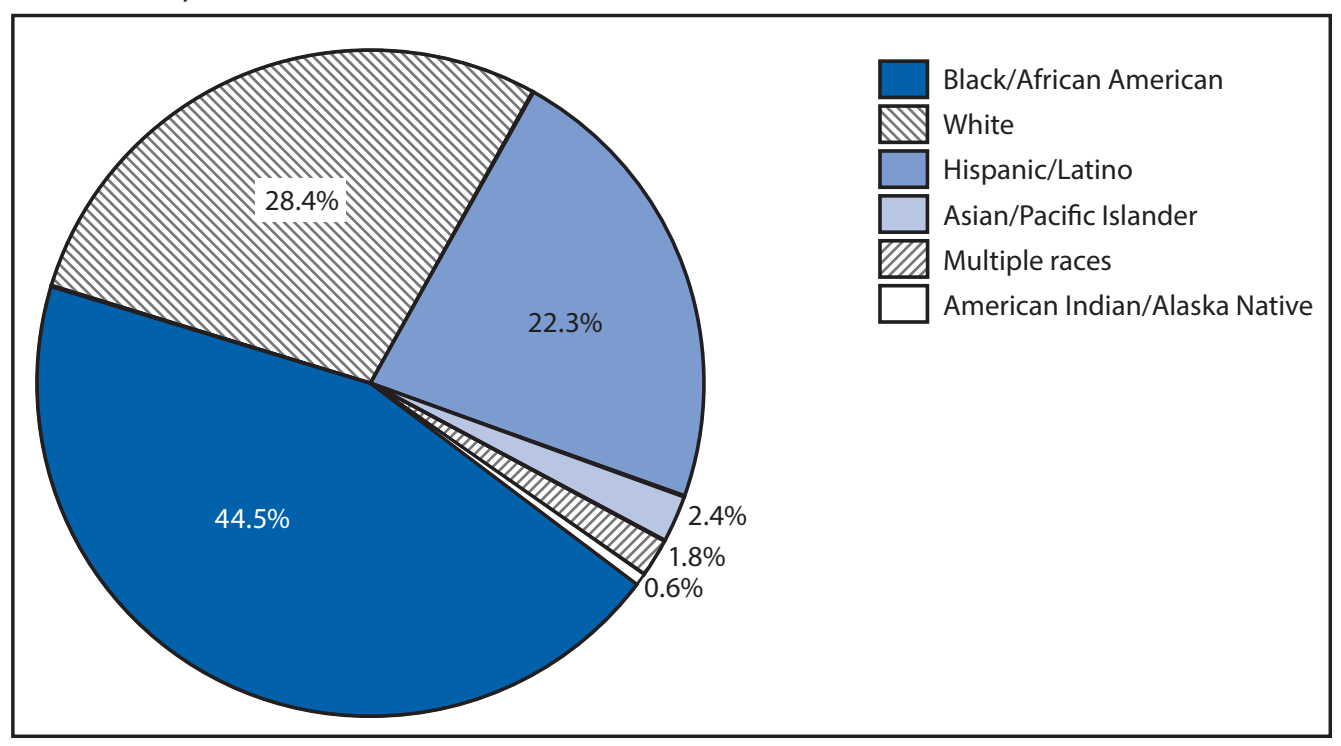

Among persons with HIV infection diagnosed in 2014, the greatest percentage was among blacks/African Americans, followed by whites, Hispanics/Latinos, Asians/Pacific Islanders, persons of multiple races, and American Indians/ Alaska Natives. 
HUMAN IMMUNODEFICIENCY VIRUS DIAGNOSES. Diagnosis incidence* - United States and U.S. territories, 2014

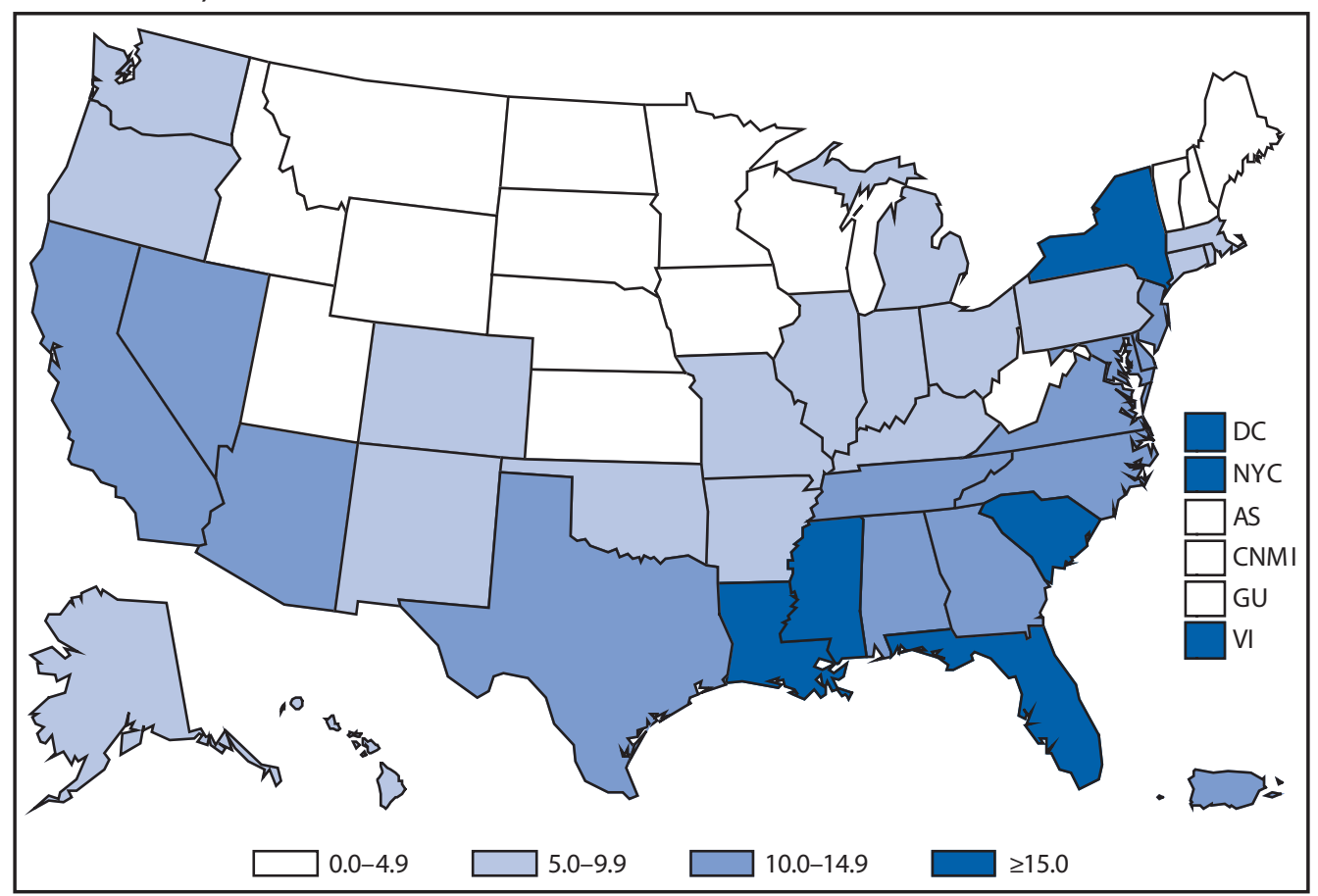

* Per 100,000 population.

The highest rates (i.e., $\geq 15$ diagnoses per 100,000 population) of HIV diagnoses were in certain states in the Southeast and Northeast as well as the District of Columbia and the U.S. Virgin Islands. 
INFLUENZA-ASSOCIATED PEDIATRIC MORTALITY. Incidence* of reported cases - United States and U.S. territories, 2014

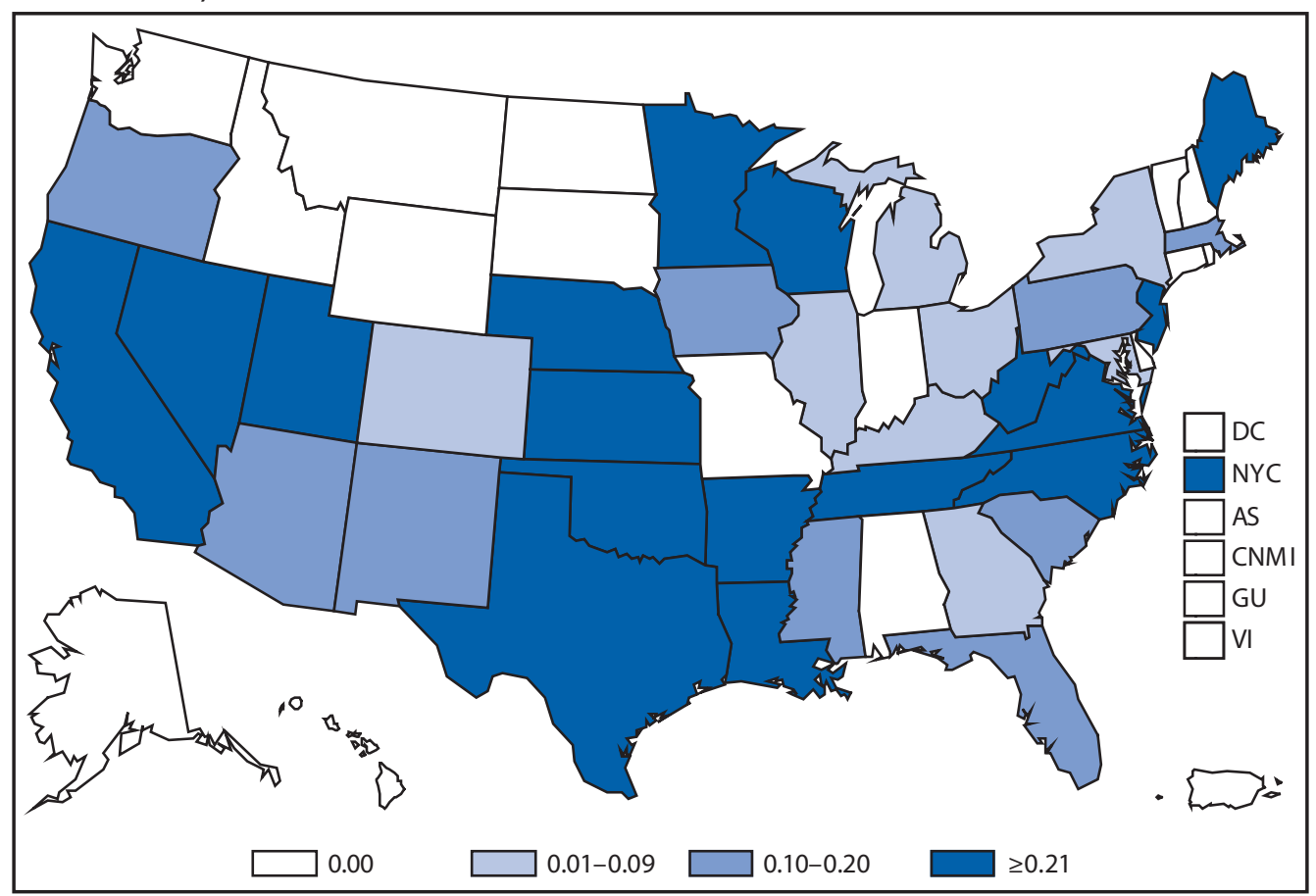

* Per 100,000 population.

In 2014, New York City and 34 states reported 141 influenza-associated pediatric deaths for an overall incidence rate of 0.19 deaths per 100,000 children aged $<18$ years. 
LEGIONELLOSIS. Incidence* of reported cases, by year — United States, 1999-2014

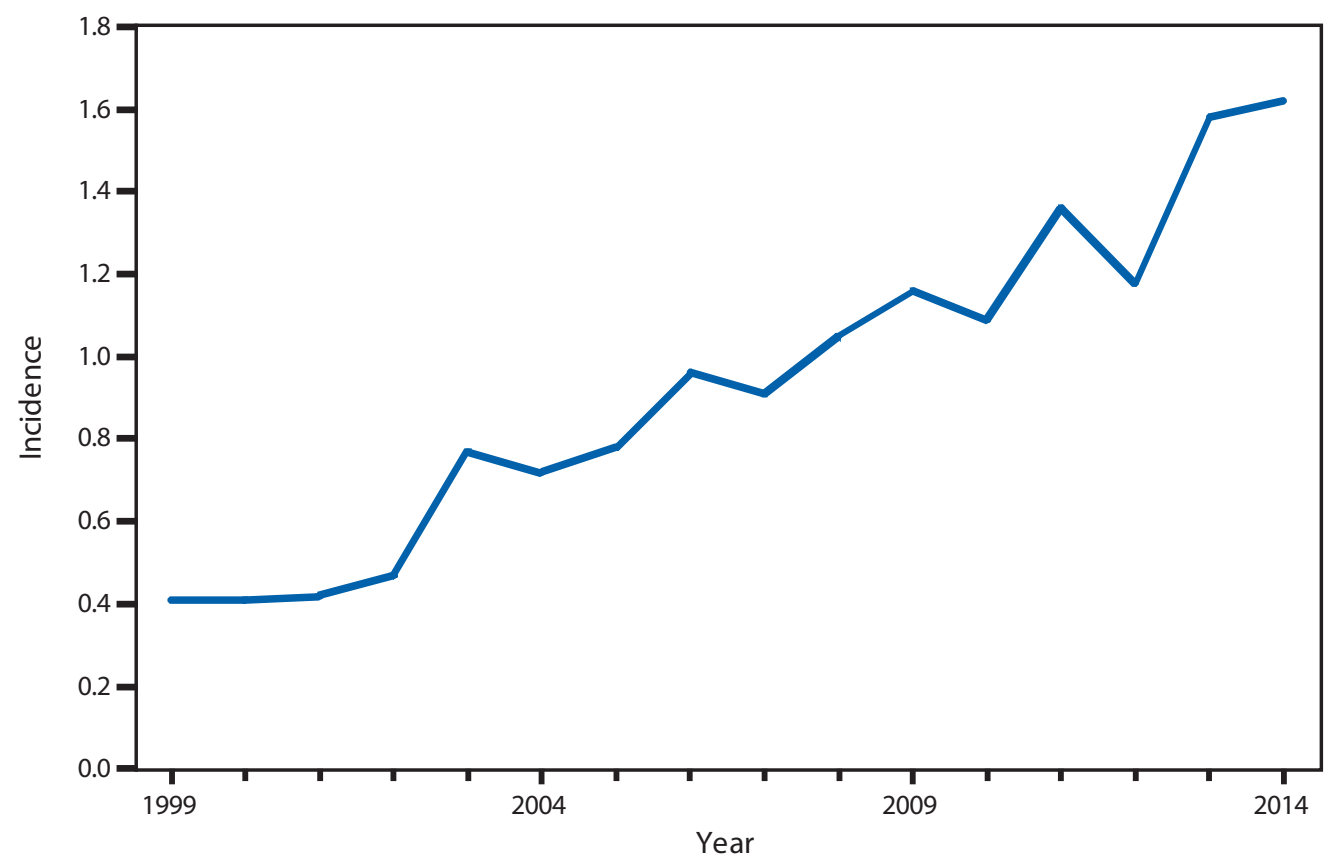

* Per 100,000 population.

From 2013 to 2014, the incidence of legionellosis increased, continuing a general increase that began in 2003. Decreases since 2003 did not result in a lower incidence beyond the immediate past year. Factors potentially contributing to this increase include increased diagnostic testing or an increase in disease transmission. 
LEPTOSPIROSIS. Number of reported cases, by year - United States and U.S. territories, 1947-2014

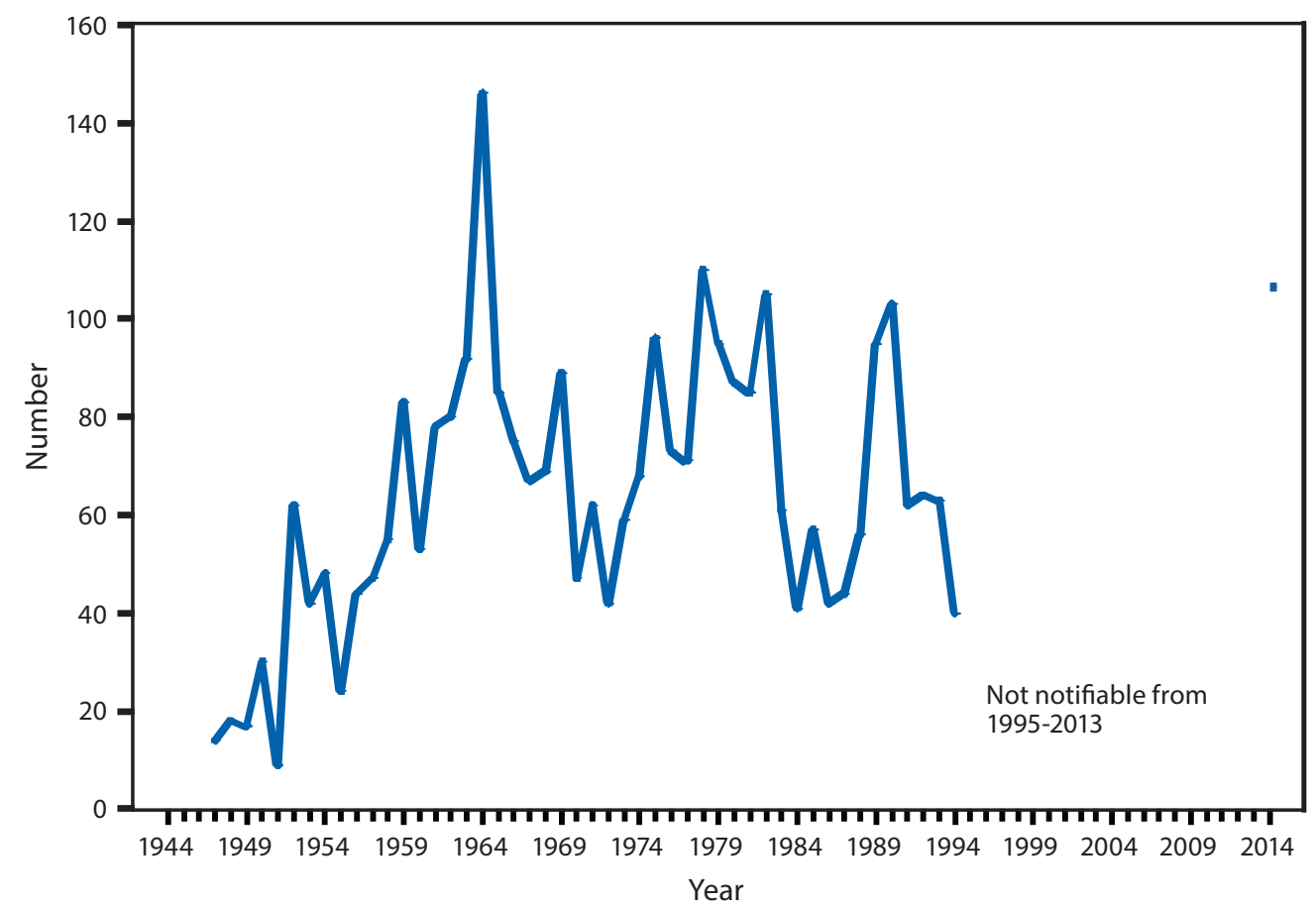

In 2014, of 107 leptospirosis cases reported, 38 were from U.S. states and 69 were from Puerto Rico, demonstrating a substantial increase in cases reported in Puerto Rico compared to all previous years that leptospirosis was notifiable (1947-1994). Although leptospirosis was first notifiable starting in 1947, territories did not begin reporting cases until 1959. Territory data for 1970 and 1978 are not available. 
LISTERIOSIS. Incidence* of reported cases — United States and U.S. territories, 2014

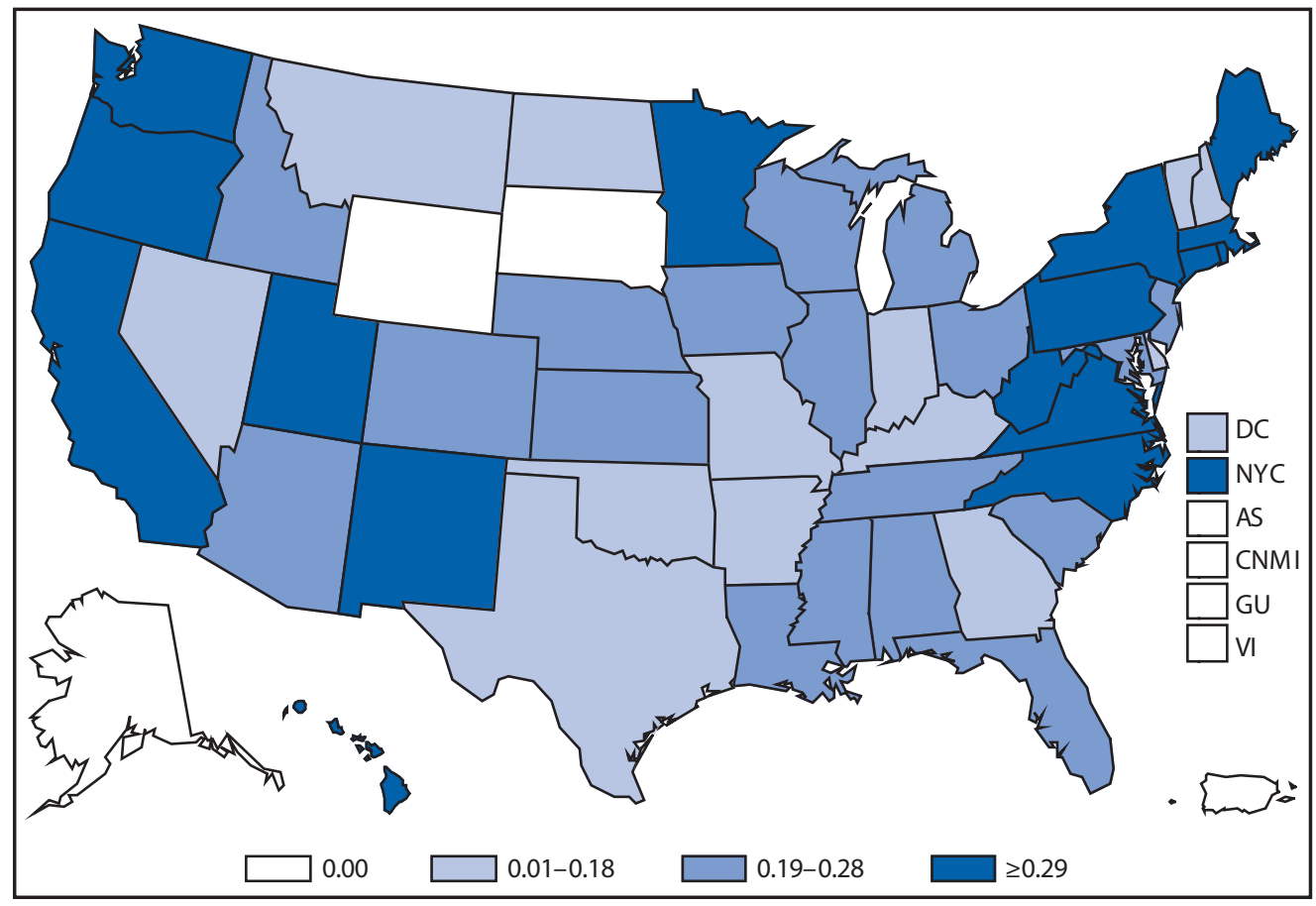

* Per 100,000 population.

In 2014, a total of 47 states, the District of Columbia, and New York City reported 769 cases of Listeriosis for an overall incidence rate of 0.24 infections per 100,000, which is unchanged from 2013. 
LYME DISEASE. Incidence* of reported confirmed cases, by county — United States, 2014

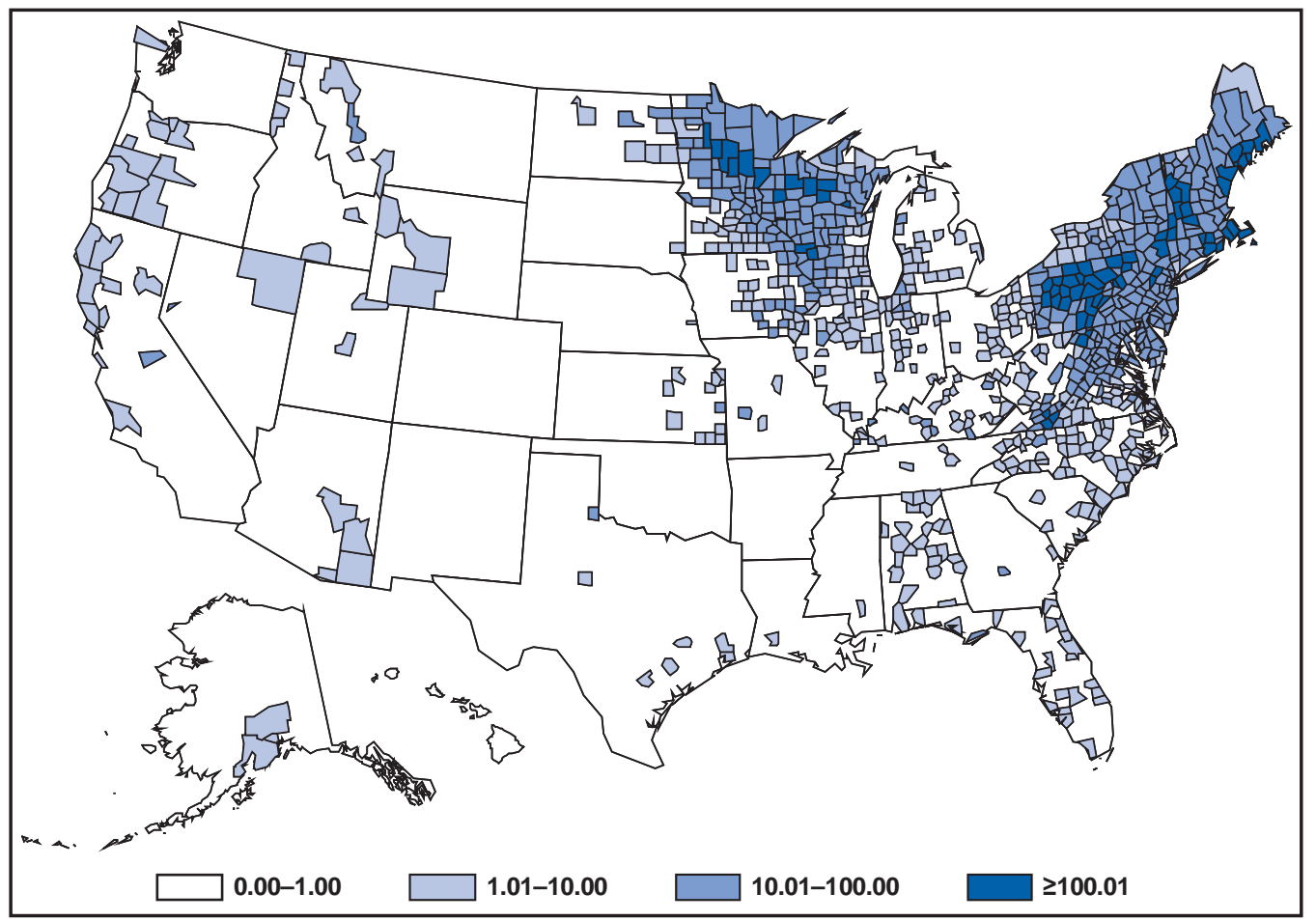

* Per 100,000 population.

Although it is one of the most common nationally notifiable diseases, Lyme disease does not occur nationwide. Approximately $95 \%$ of confirmed Lyme disease cases are reported from states in the Northeast, mid-Atlantic, and upper Midwest. Many cases reported from other states are associated with travel to areas where Lyme disease is common. A rash that can be confused with and might be reported as Lyme disease sometimes occurs following bites of the lone star tick (Amblyomma americanum). These ticks, which do not transmit the Lyme disease bacterium, are common human biting ticks in the southeastern United States. 
MALARIA. Number of reported cases — United States and U.S. territories, 2014

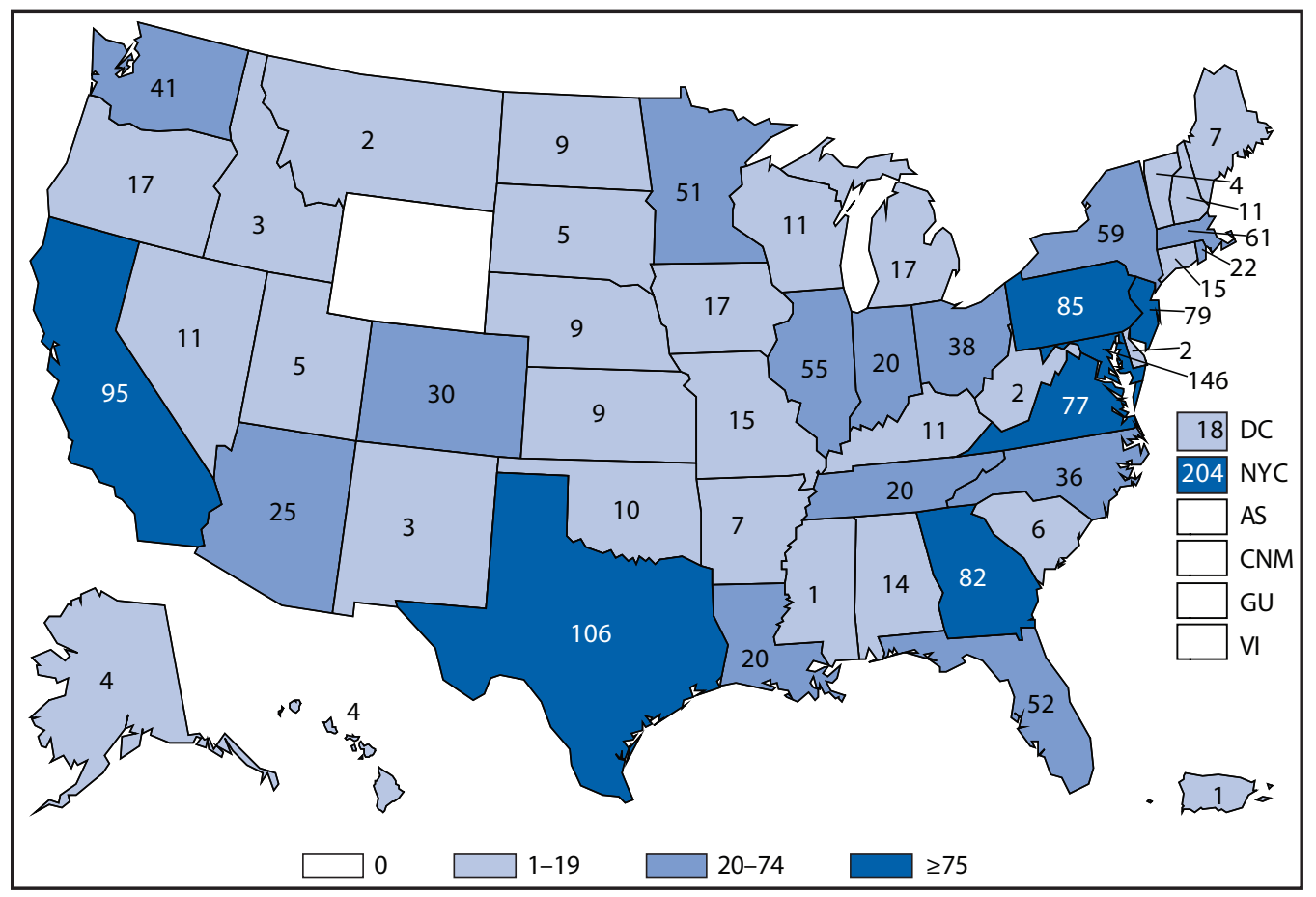

In 2014, cases of malaria were reported from almost every jurisdiction, and nearly all cases reported in the United States were imported. Cases in eight jurisdictions (California, Georgia, Maryland, New Jersey, New York City, Pennsylvania, Texas, and Virginia) accounted for $53 \%$ of the reported cases because of large immigrant populations and international travelers. 
MEASLES. Incidence* of reported cases, by year — United States, 1979-2014

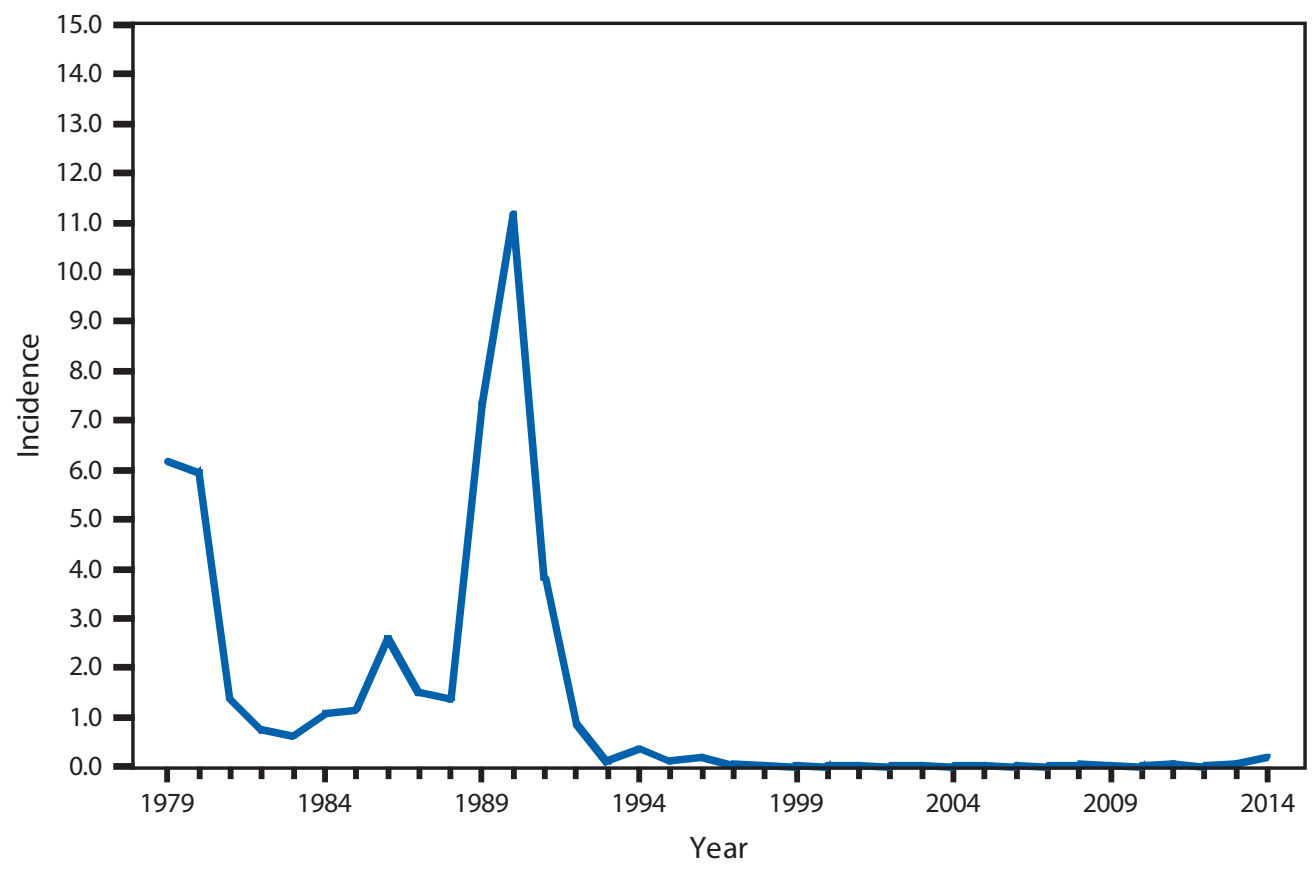

* Per 100,000 population. 
MENINGOCOCCAL DISEASE. Incidence* of reported cases, by year — United States, 1984-2014

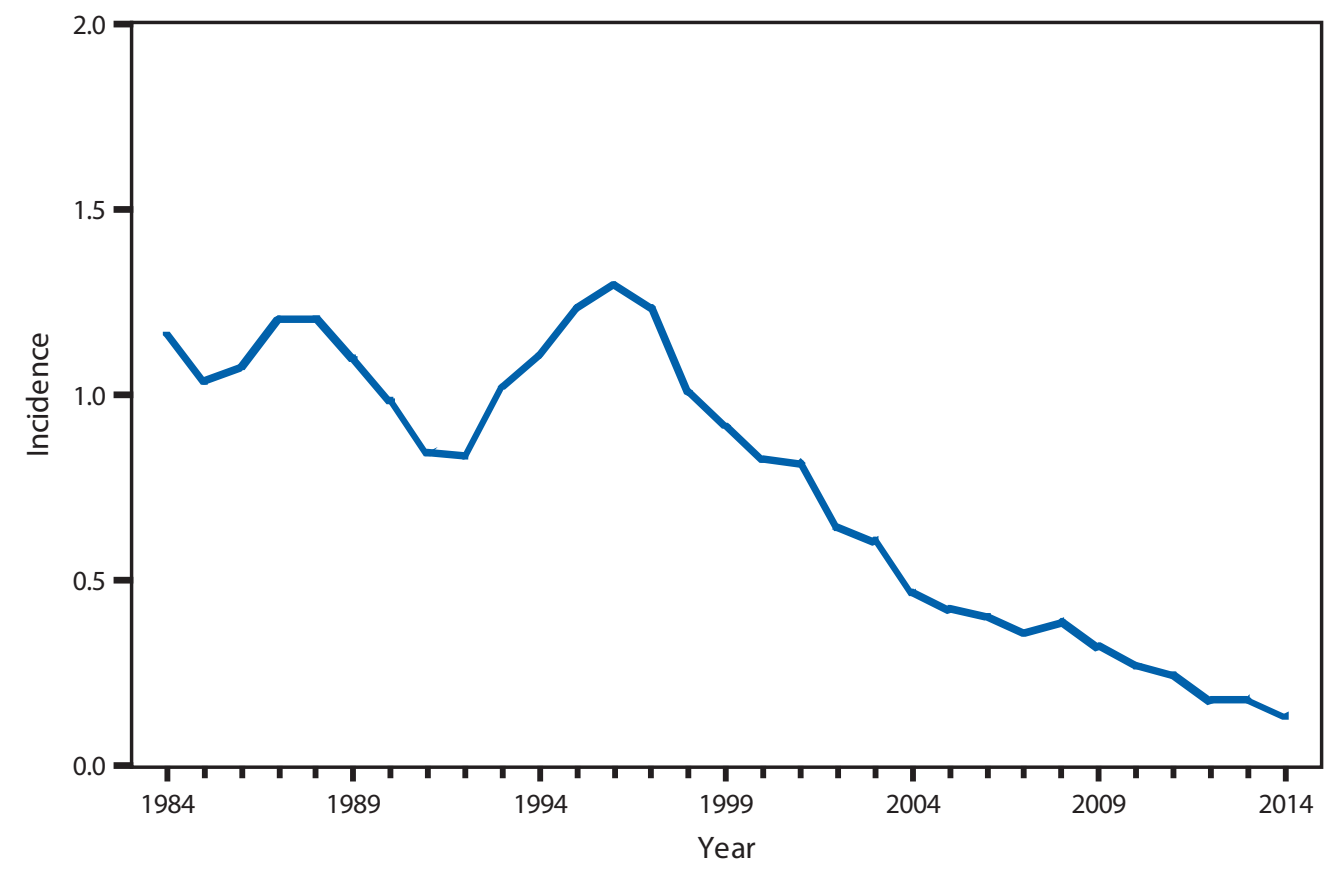

* Per 100,000 population.

In 2014, meningococcal disease incidence remained at an historic low in the United States. However, Neisseria meningitidis remains an important cause of bacterial meningitis and sepsis in the United States. 
MUMPS. Incidence* of reported cases, by year — United States, 1989-2014

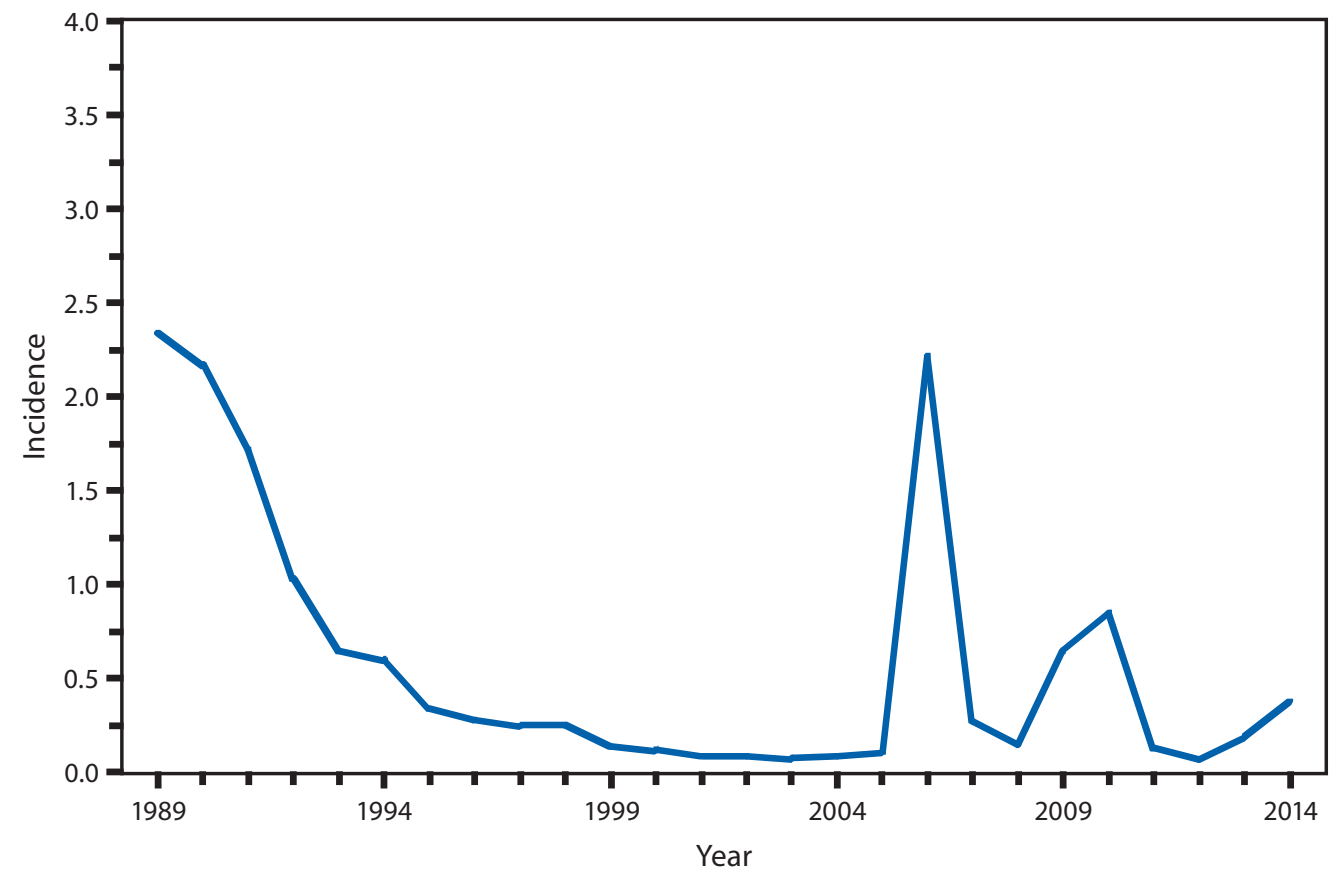

* Per 100,000 population.

The widespread use of a second dose of mumps vaccine beginning in 1989 was followed by historically low morbidity until 2006, when the U.S. experienced the largest mumps outbreak in two decades. The 2006 outbreak of approximately 6,000 cases primarily affected college students aged 18-24 years in the Midwest. A second large outbreak occurred during 2009-2010 and affected Orthodox Jewish communities in the Northeast. 
PERTUSSIS. Incidence* of reported cases, by age — United States, 2014

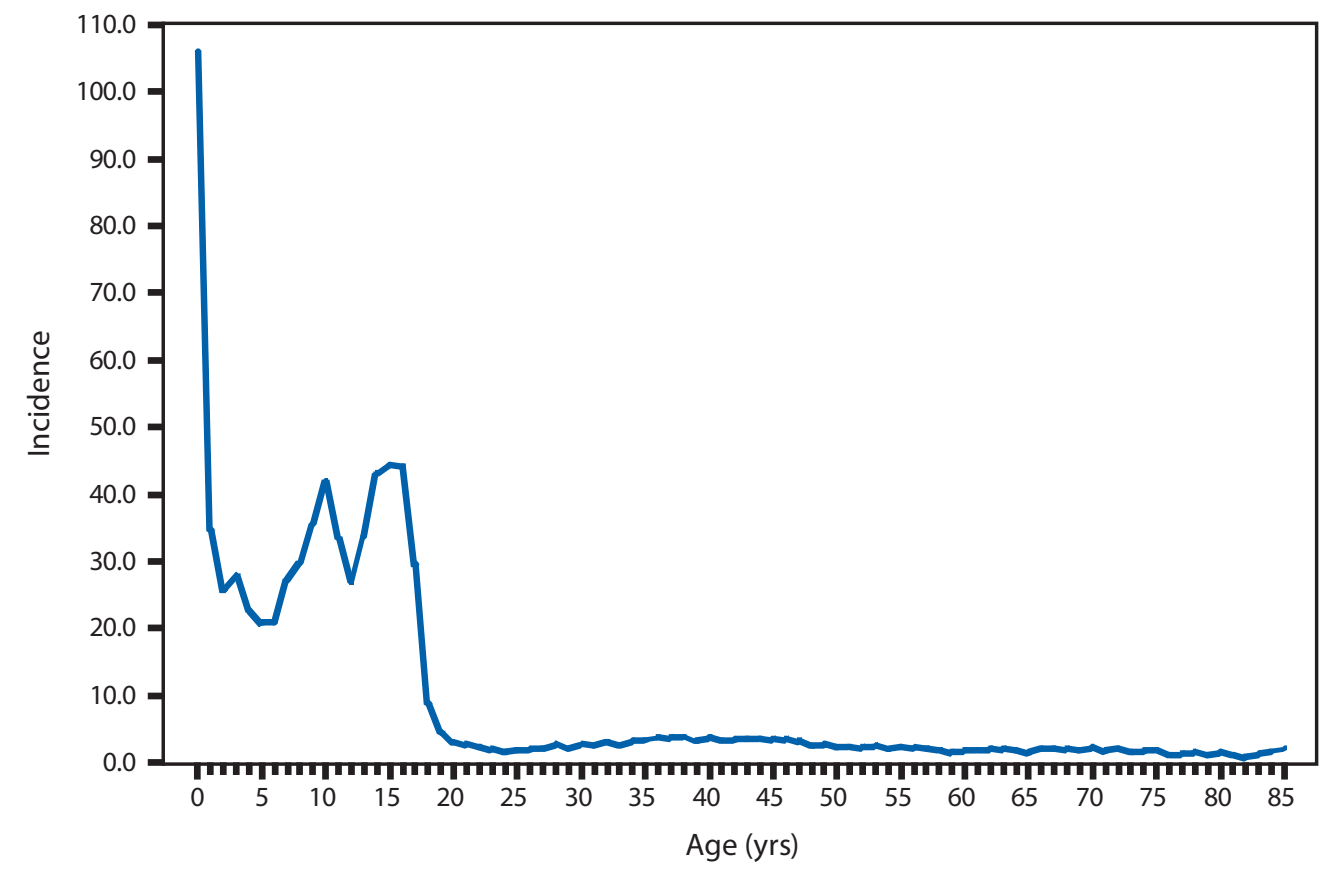

* Per 100,000 population.

In 2014, the incidence of pertusis among infants remained highest, and the increased incidence among adolescents expanded to include persons aged $10-15$ years. 
PERTUSSIS. Incidence* of reported cases, by year — United States, 1984-2014

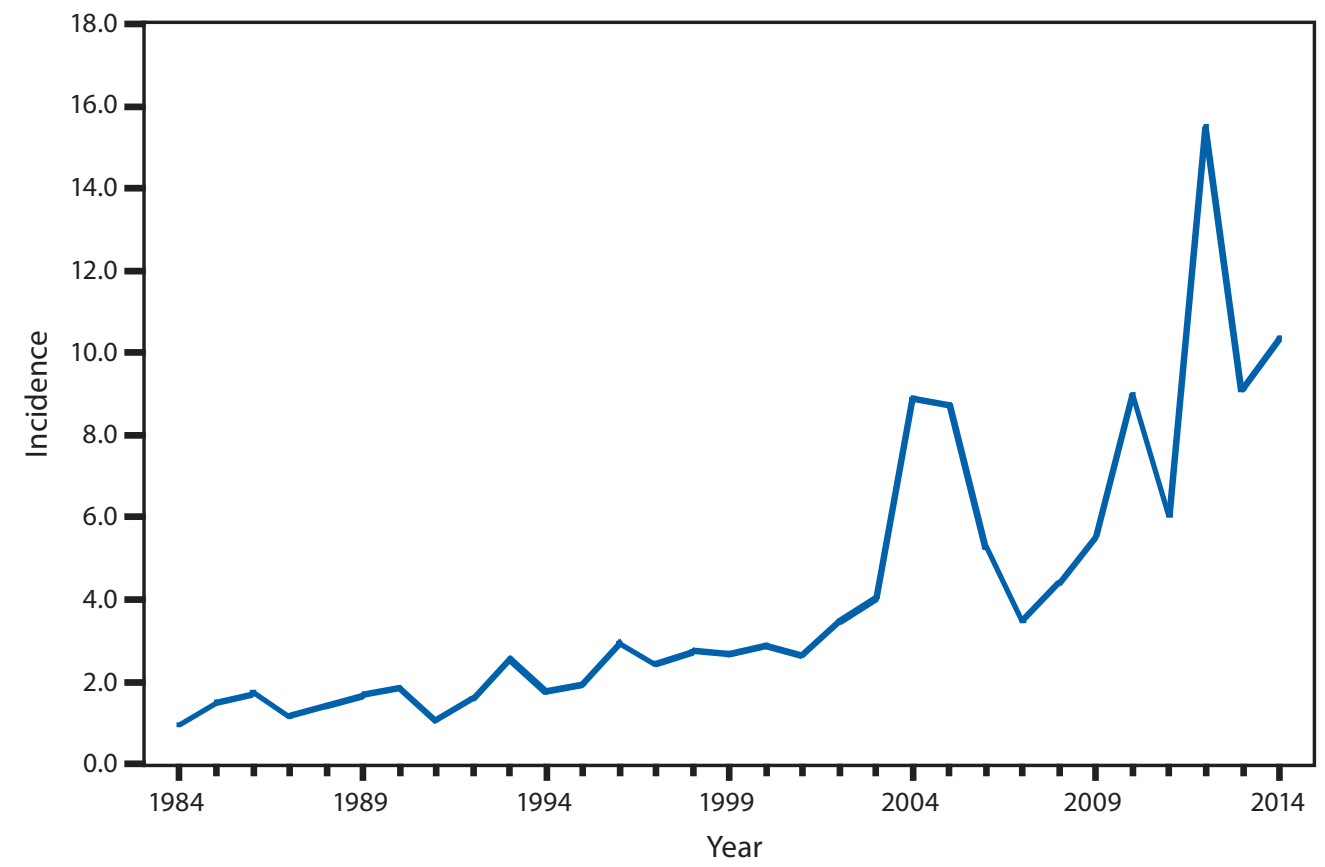

* Per 100,000 population.

Although substantially lower than the incidence observed during the prevaccine era, overall pertussis incidence remains elevated compared with the lowest historical rates reported during the 1990 s and early 2000 s. 
Q FEVER, ACUTE AND CHRONIC. Number* of reported cases — United States and U.S. territories, 2014

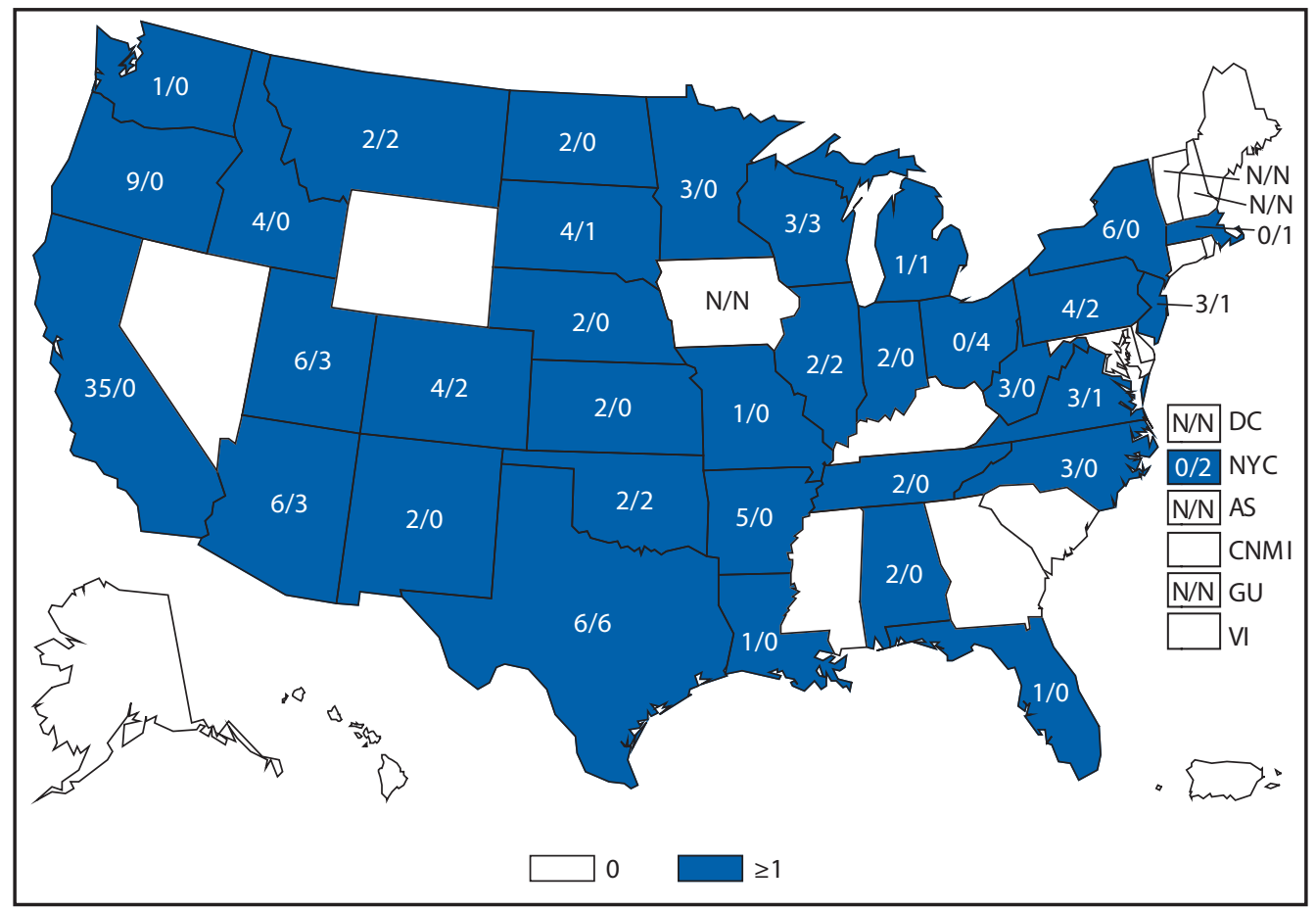

Abbreviation: $\mathrm{N}=$ not reportable.

* Number of Q fever acute cases/number of Q fever chronic cases.

Q fever, caused by Coxiella burnetii, is reported throughout the United States. Human cases of Q fever most often result from contact with infected livestock, especially sheep, goats, and cattle. 
RABIES, ANIMAL. Number* of reported cases, by county — United States, 2014

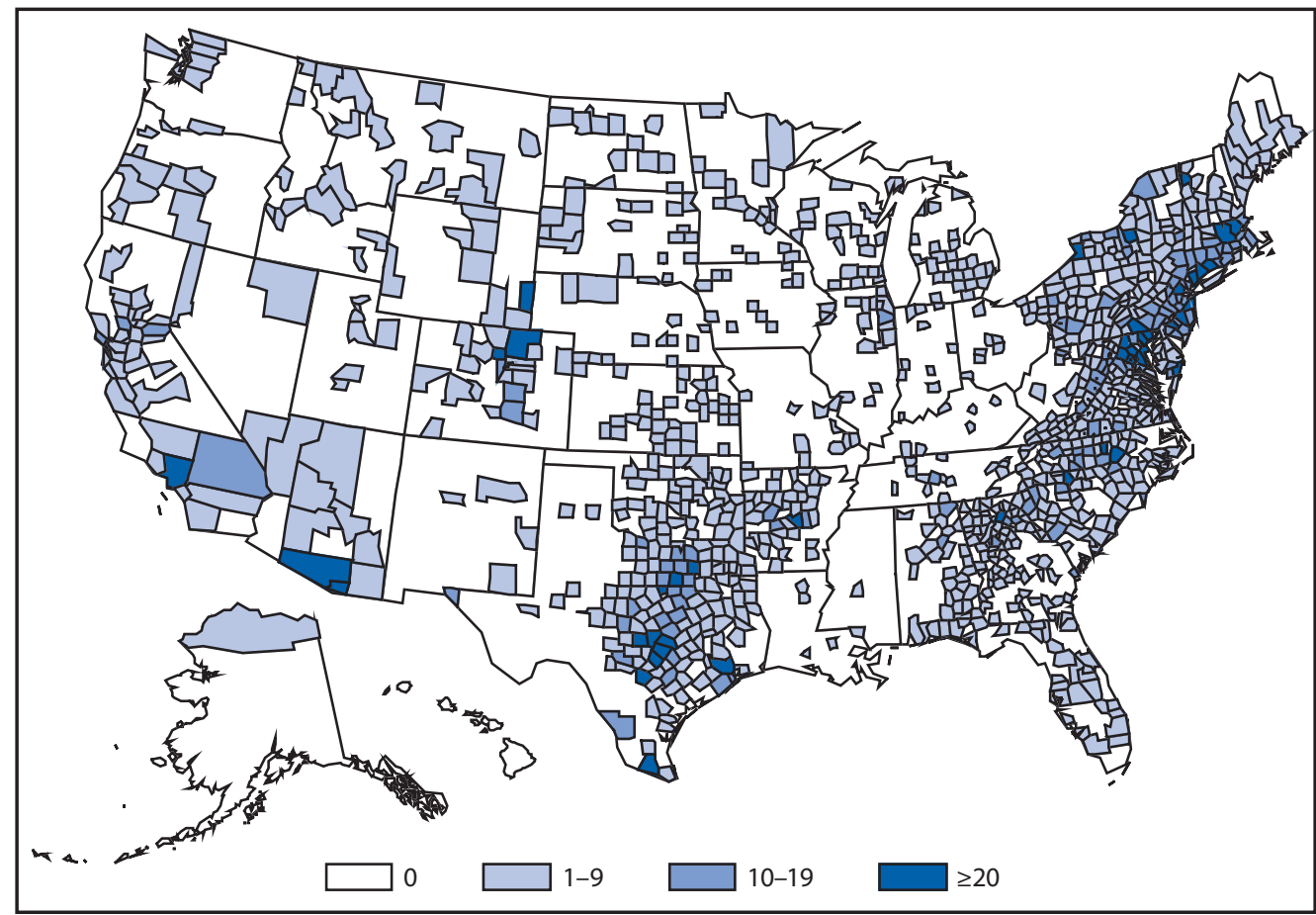

* Data from the Division of High Consequence Pathogens and Pathology, National Center for Emerging and Zoonotic Infectious Diseases.

In 2014, rabid animals were reported in all jurisdictions except Hawaii. Because reporting is based on the number of animals tested, the burden of disease is likely underestimated. 
Morbidity and Mortality Weekly Report

RUBELLA. Incidence* of reported cases, by year — United States, 1984-2014

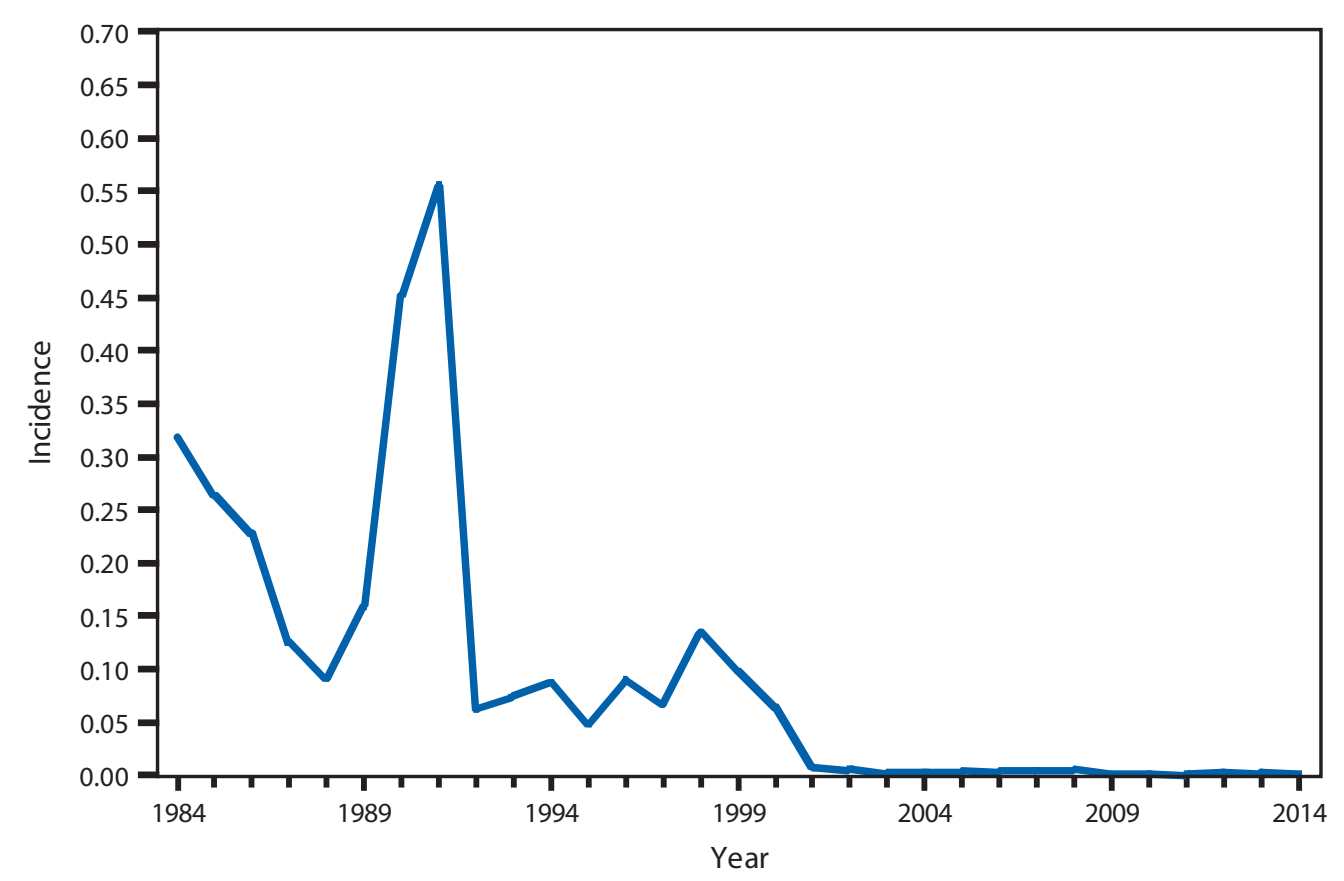

* Per 100,000 population. 
SHIGA TOXIN-PRODUCING ESCHERICHIA COLI (STEC). Incidence* of reported cases - United States and U.S. territories, 2014

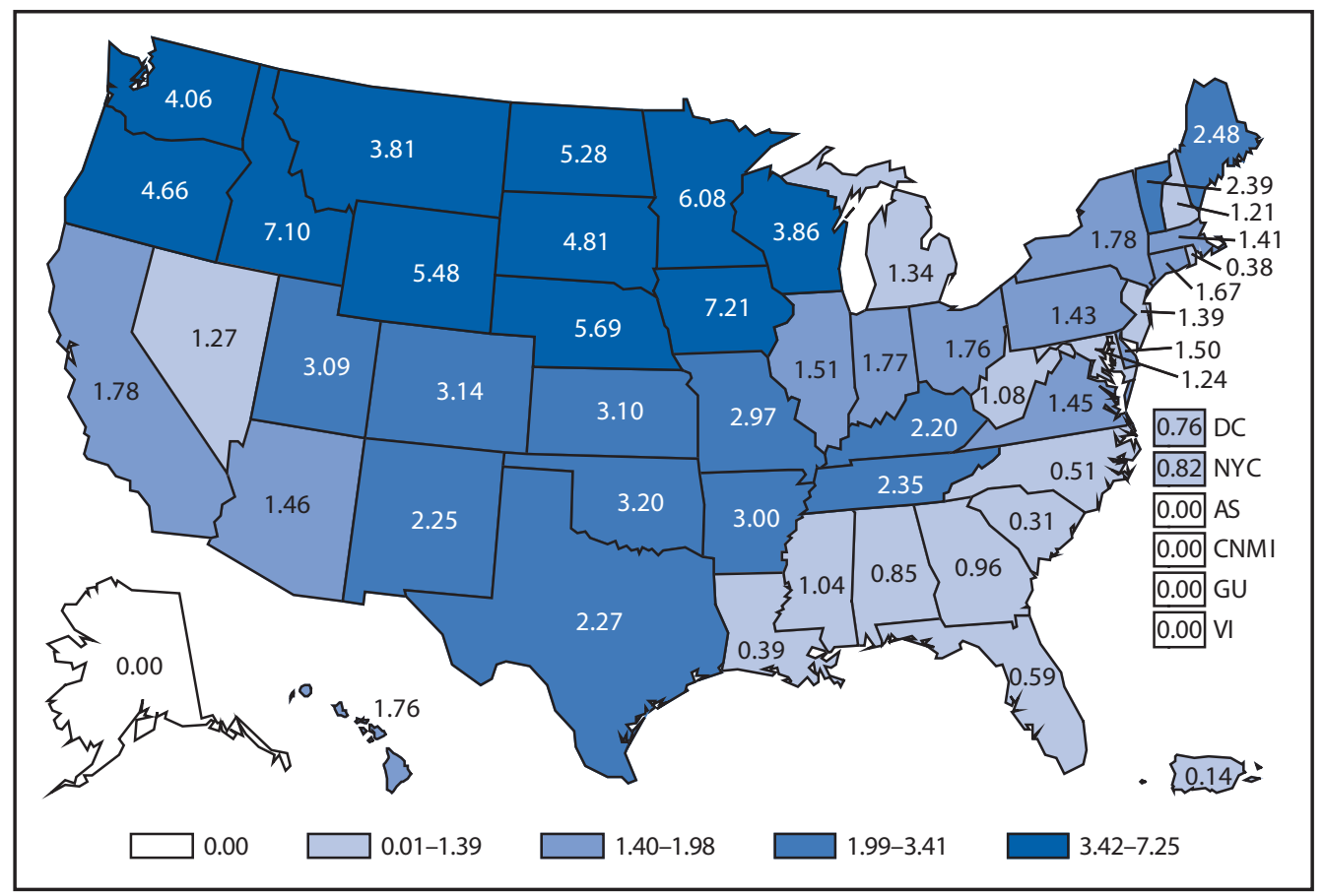

* Per 100,000 population.

Incidence rates for STEC infection were generally highest in northern states. 
SALMONELLOSIS AND SHIGELLOSIS. Incidence* of reported cases, by year - United States, 1984-2014

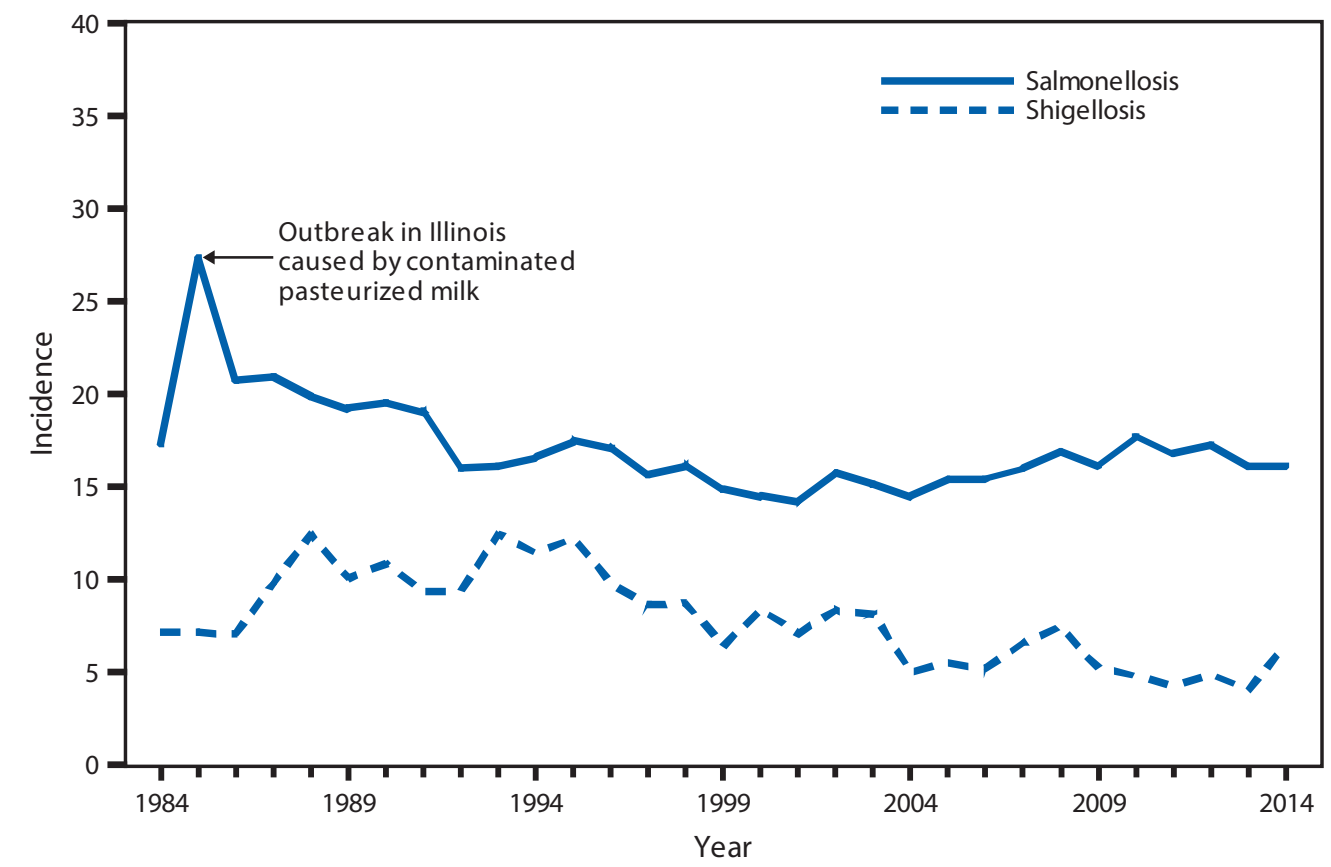

* Per 100,000 population.

Although incidence rates of salmonellosis have remained relatively stable since the early 1990s, incidence rates of shigellosis during the same period have followed a general decreasing trend. 
SPOTTED FEVER RICKETTSIOSIS. Number of reported cases, by county — United States, 2014

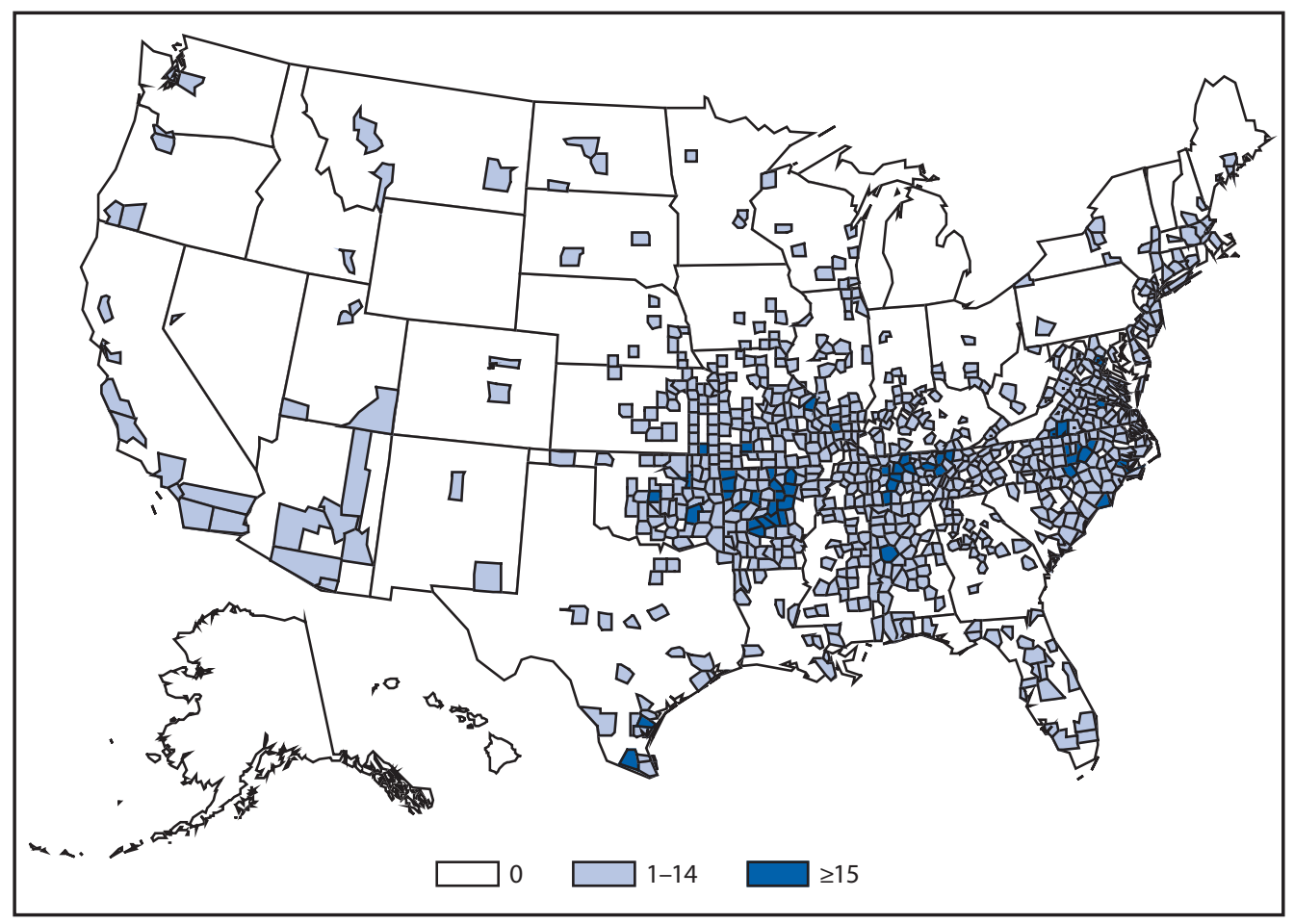

In the United States the majority of cases of spotted fever rickettsiosis are attributed to infection with Rickettsia rickettsii, the causative agent of Rocky Mountain spotted fever (RMSF), but might also be from other agents such as Rickettsia parkeri and Rickettsia species 364D. RMSF is ubiquitous across the United States, which represents the widespread nature of the three tick vectors known to transmit RMSF: Dermacentor variabilis in the East, Dermacentor andersoni in the West, and Rhipicephalus sanguineus in parts of Arizona. 
SYPHILIS, CONGENITAL. Reported cases among infants, by year of birth and incidence* of primary and secondary syphilis among women — United States, 2005-2014

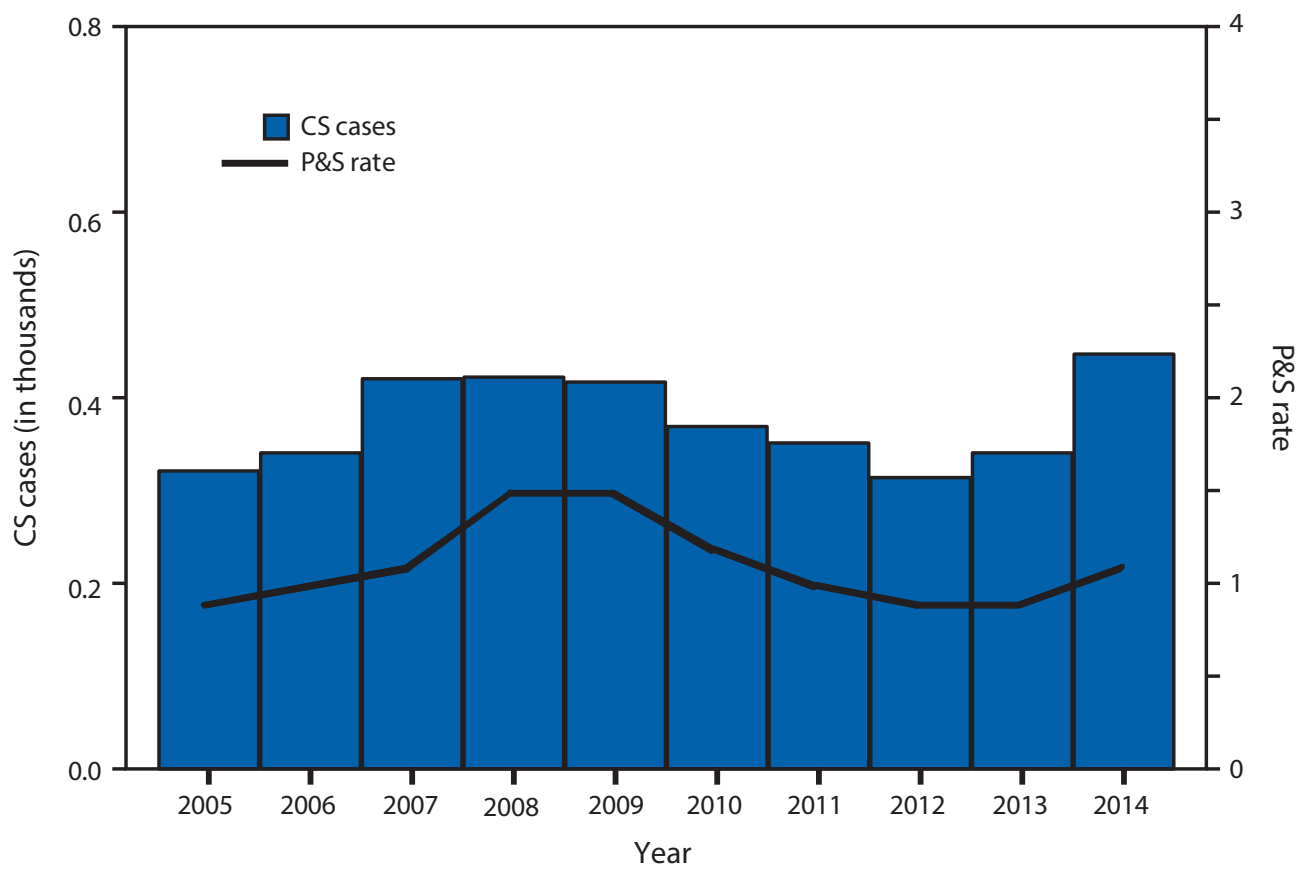

Abbreviations: $\mathrm{CS}=$ congenital syphilis; $\mathrm{P} \& \mathrm{~S}=$ primary and secondary syphilis.

* Per 100,000 population.

After decreasing from 431 cases in 2008 to 322 cases in 2012, the number of reported congenital syphilis cases increased to 348 in 2013. From 2013 to 2014, reported cases increased $31.6 \%$ to 458 in 2014. As has been observed historically, this increase parallels a similar increase $(21.3 \%)$ in the rate of primary and secondary syphilis among women during 2013-2014. 
SYPHILIS, PRIMARY AND SECONDARY. Rate* of reported cases, by sex and male-to-female rate ratio United States, 2005-2014

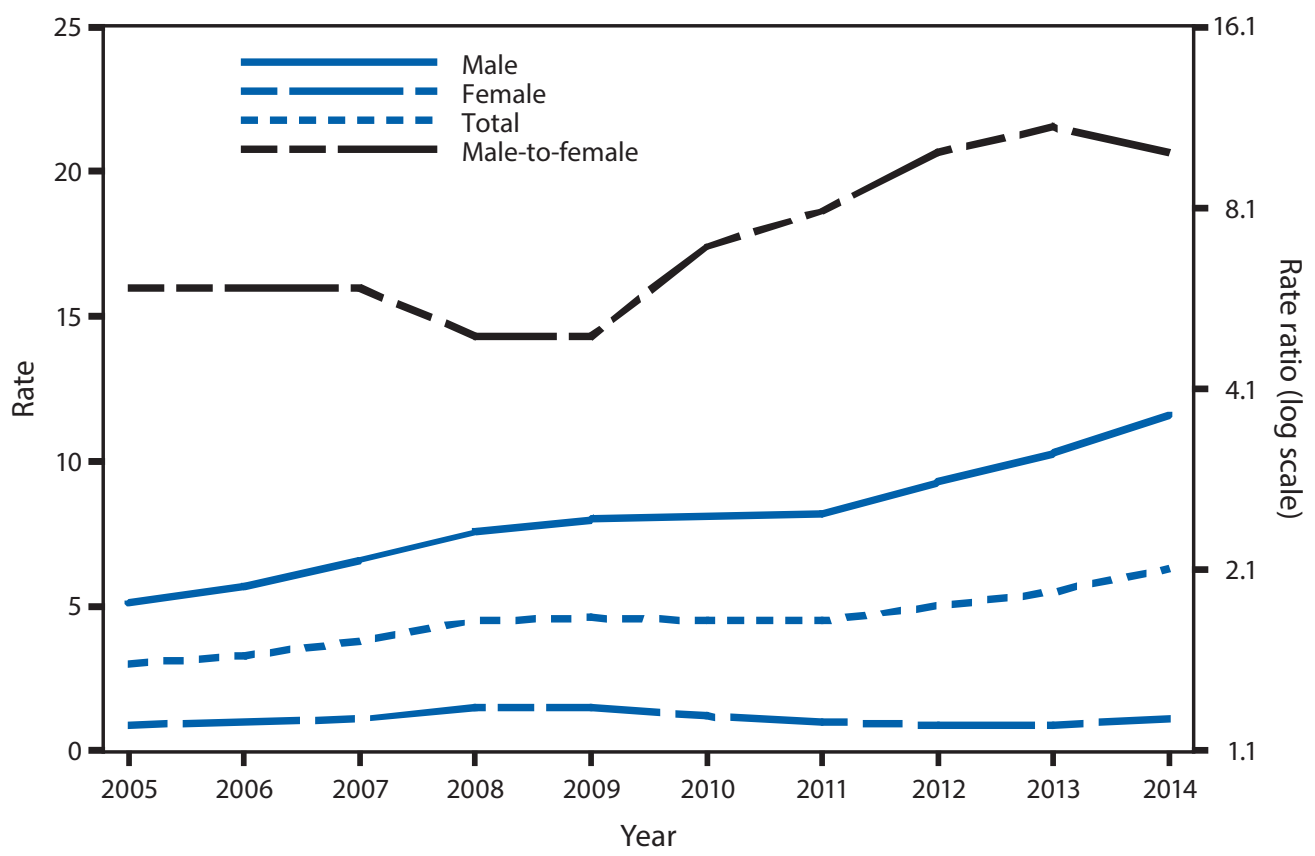

* Per 100,000 population.

In 2014, the rate of reported primary and secondary (P\&S) syphilis cases among men (11.6 cases per 100,000 males) was substantially higher than rates among women (1.1), and men accounted for the large majority (87.1\%) of P\&S syphilis cases with known sex. Among men, the rate of P\&S syphilis has increased every year since 2000, and during 2013-2014, the rate among men increased from 10.3 to 11.6 (12.6\%). In contrast, the P\&S syphilis rate among women has fluctuated between 0.8 and 1.8 since 2000. During 2013-2014, the P\&S syphilis rate among women increased from 0.9 to $1.1(21.3 \%)$. 
SYPHILIS, PRIMARY AND SECONDARY. Incidence* of reported cases - United States and U.S. territories, 2014

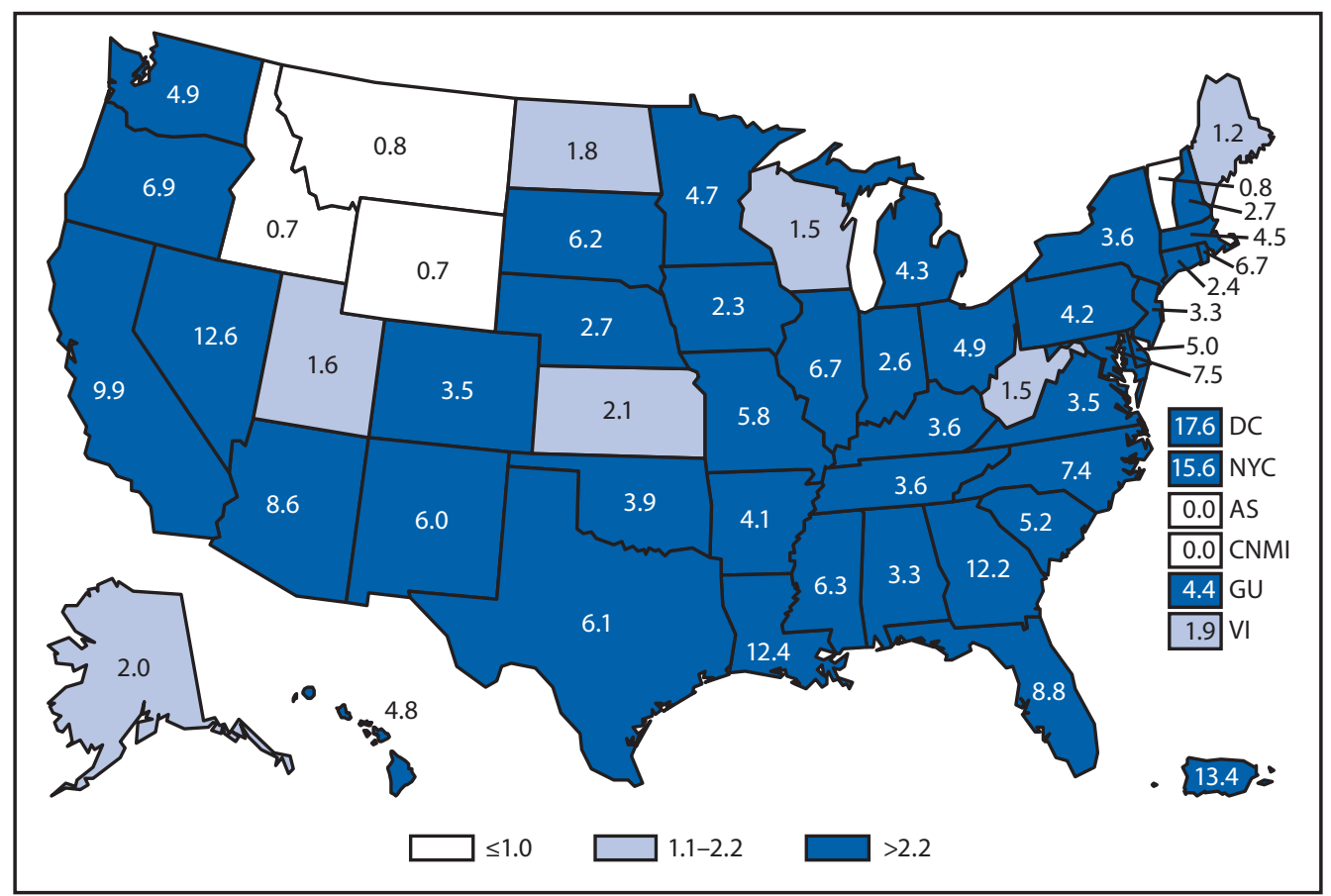

* Per 100,000 population.

In 2014, rates of reported primary and secondary (P\&S) syphilis cases per 100,000 population ranged by state from 0.7 in Wyoming to 12.6 in Nevada. The P\&S syphilis rate in the District of Columbia was 17.6. 
TRICHINELLOSIS. Number of reported cases, by year — United States, 1984-2014

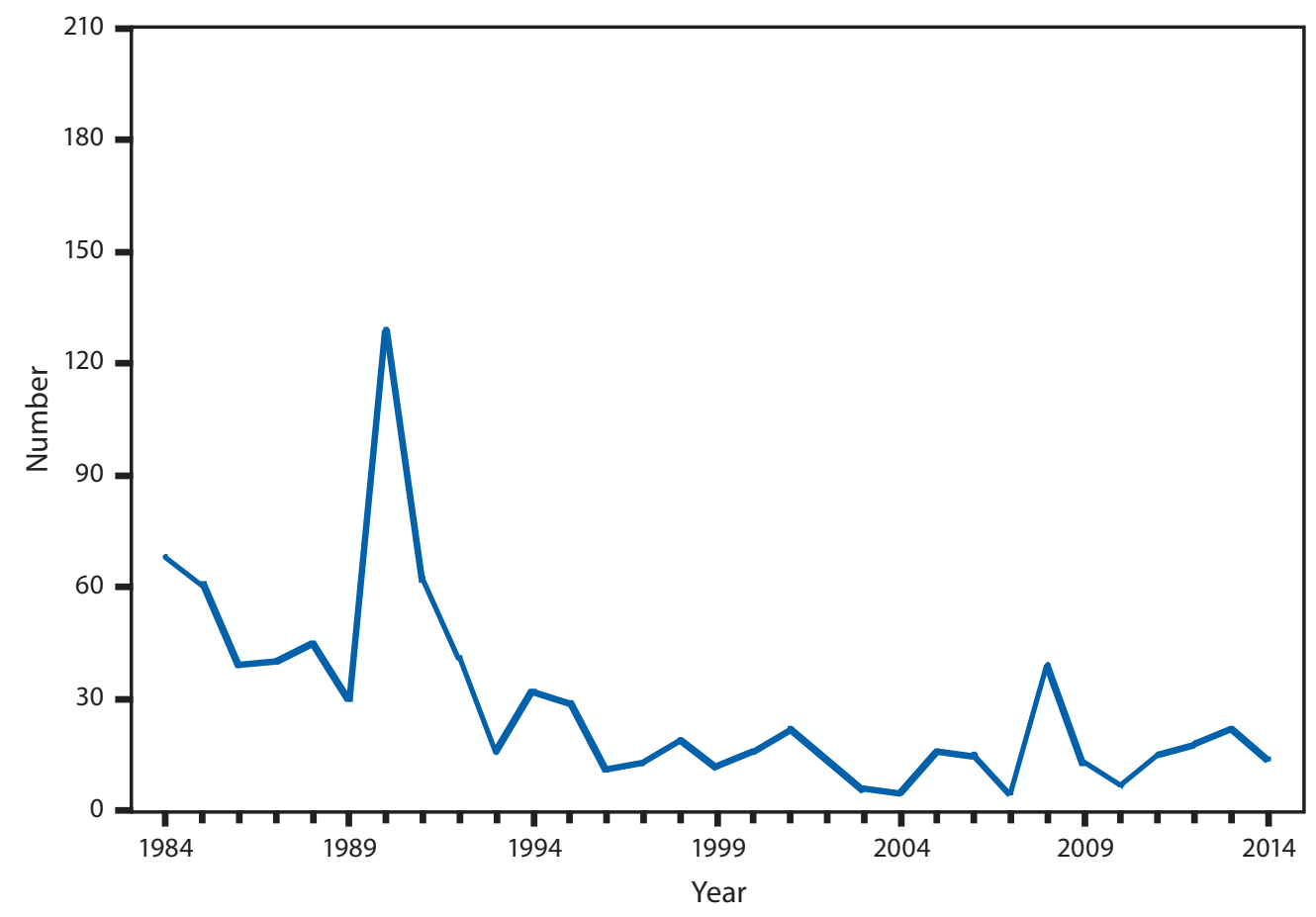

In 2014, a total of 13 trichinellosis cases were reported. One outbreak of two confirmed and two probable cases occurred in persons from four states who consumed meat from a black bear that was hunted in Alaska. Overall, a majority of reported trichinellosis cases occurred in persons with a history of consumption of undercooked wild game meat. 
TUBERCULOSIS. Incidence* of reported cases — United States and U.S. territories, 2014

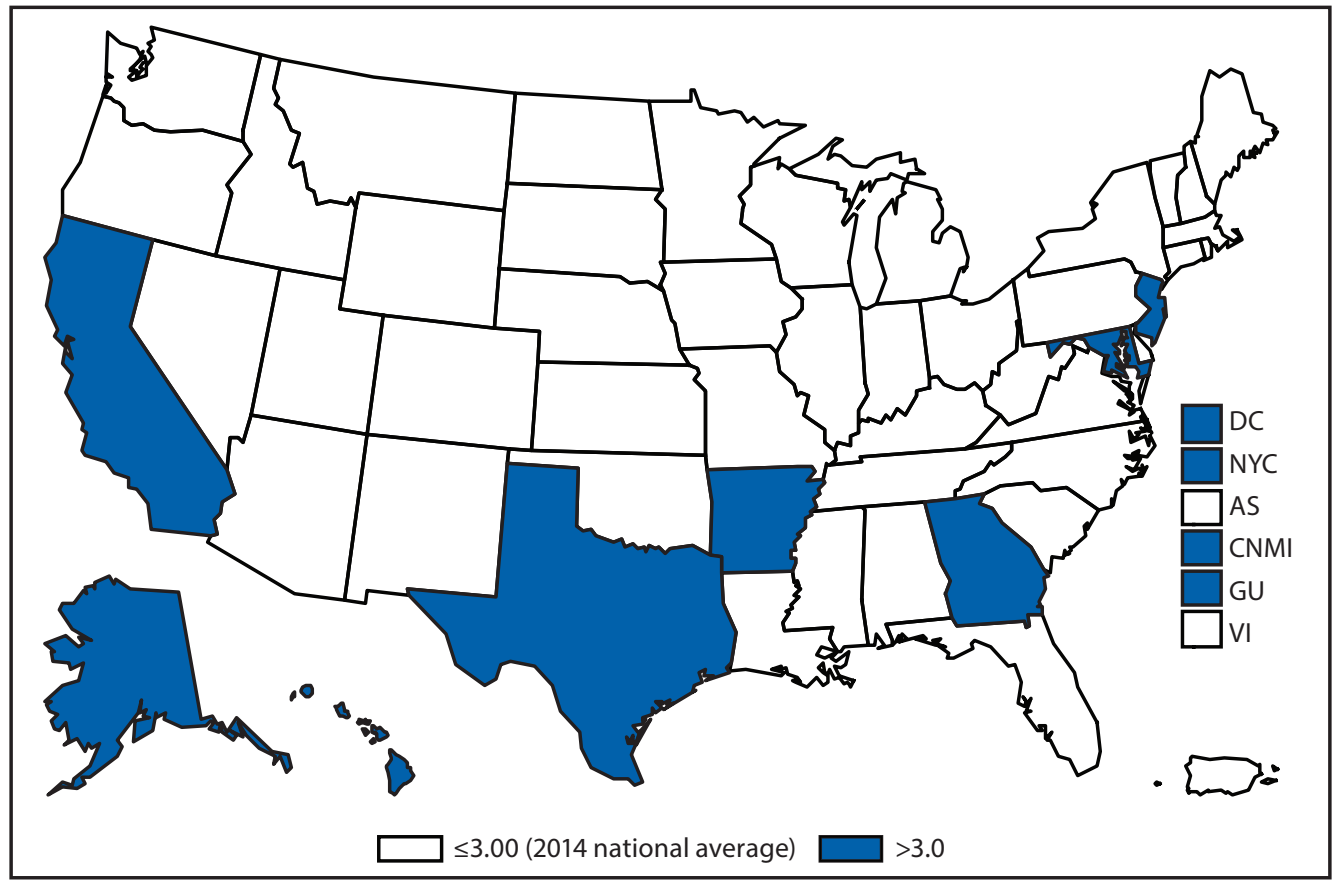

* Per 100,000 population.

In 2014, eight states, New York City, and the District of Columbia had tuberculosis (TB) incidence rates above the 2013 national average of 3.0 per 100,000 persons. The decline in the TB incidence rate in 2014 was the smallest in over two decades and there was not much change from 2013. 
TUBERCULOSIS. Incidence* of reported cases, by race/ethnicity — United States, 2004-2014

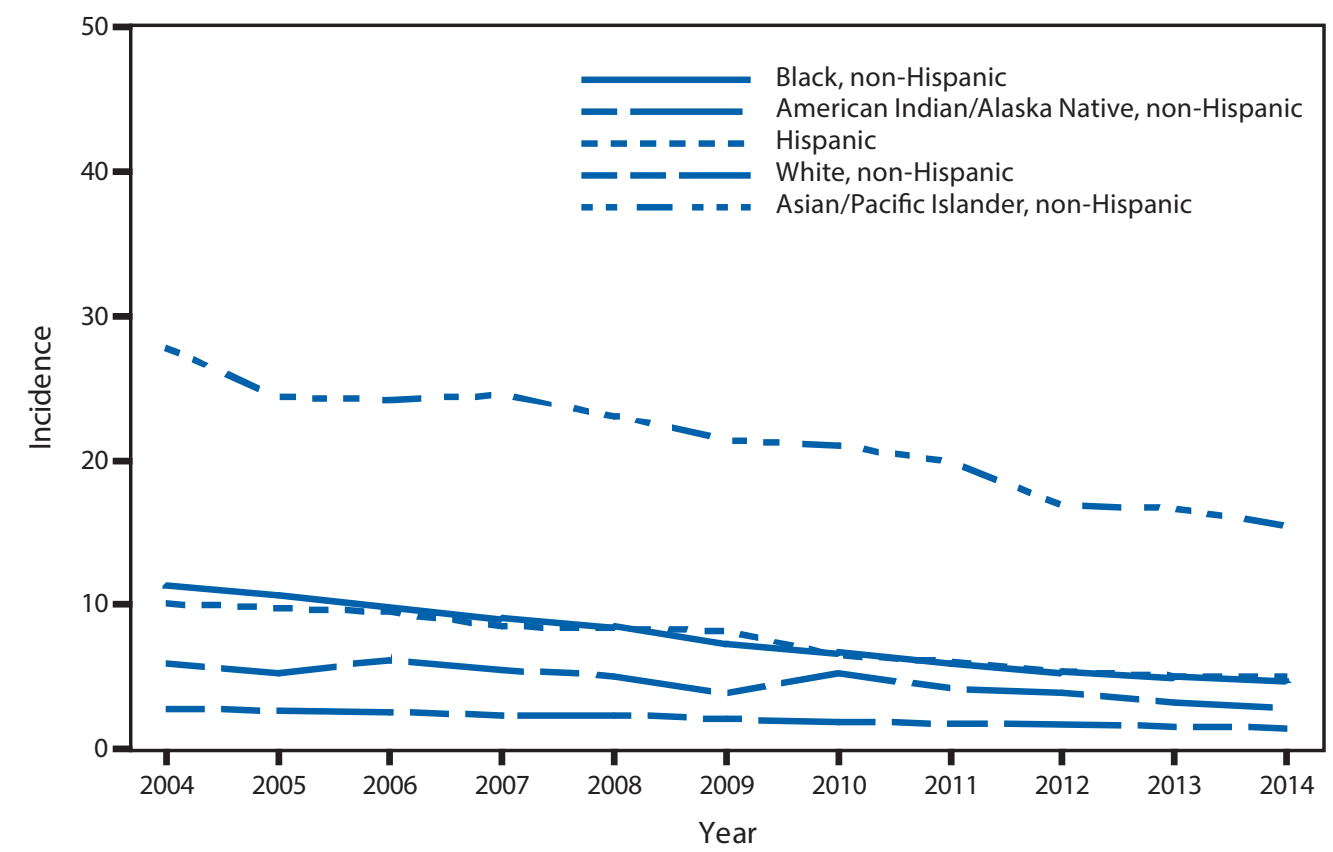

* Per 100,000 population. Data from the Division of Tuberculosis Elimination, National Center for HIV/AIDS, Viral Hepatitis, STD, and TB Prevention.

Declines in tuberculosis (TB) incidence were reported in all race-ethnic groups in 2014 except Hispanics, which was largely unchanged. TB incidence in the Asian/Pacific Islanders continues to be much higher than all other race and ethnic groups. 
TUBERCULOSIS. Number* of reported cases among U.S.-born and foreign-born persons, ${ }^{\dagger}$ by year United States, 2004-2014

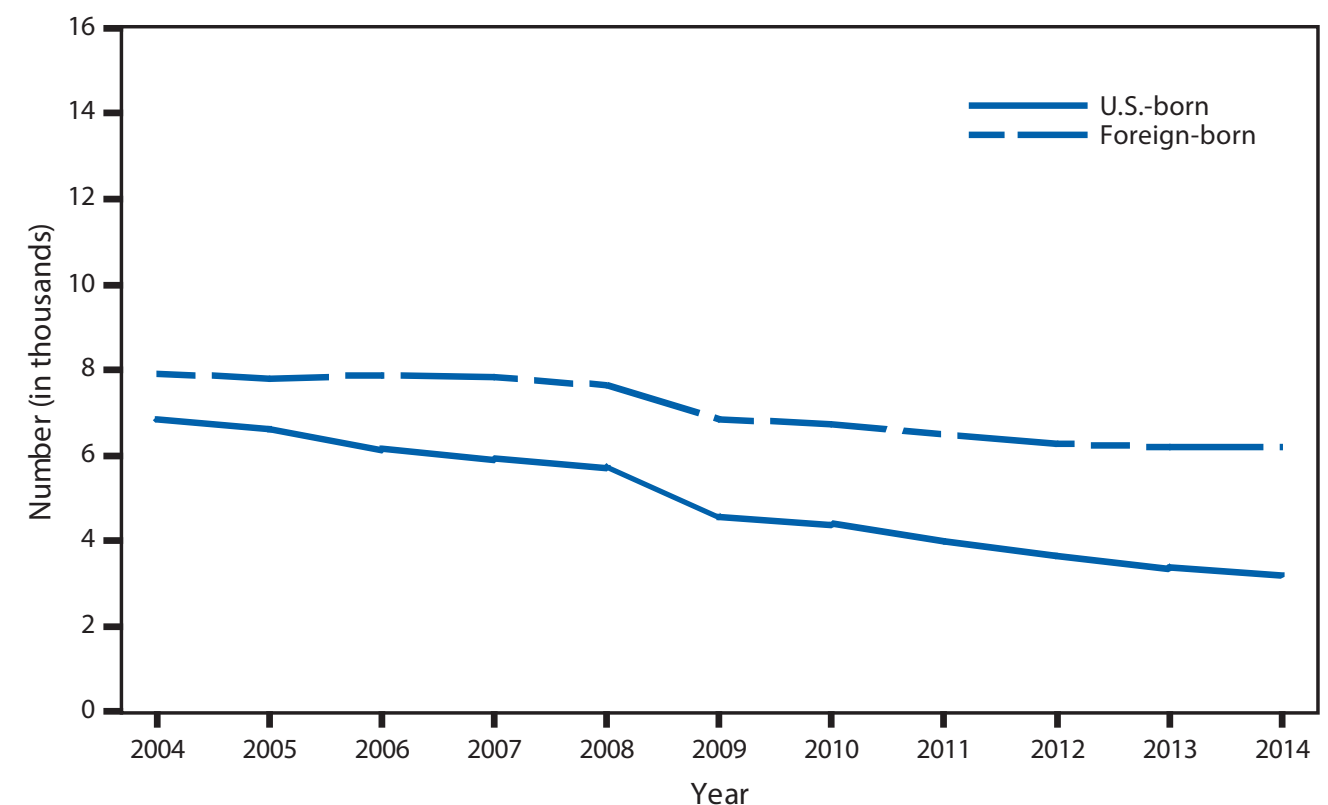

* Number represented is in thousands. Data from the Division of Tuberculosis Elimination, National Center for HIV/AIDS, Viral Hepatitis, STD, and TB Prevention.

${ }^{\dagger}$ For 18 cases, origin of patients was unknown.

The proportion of tuberculosis cases in foreign-born persons continues to increase. In 2014, of 9,421 reported cases, $6,215(66 \%)$ occurred among foreign-born persons. 
TULAREMIA. Number of reported cases — United States and U.S. territories, 2014

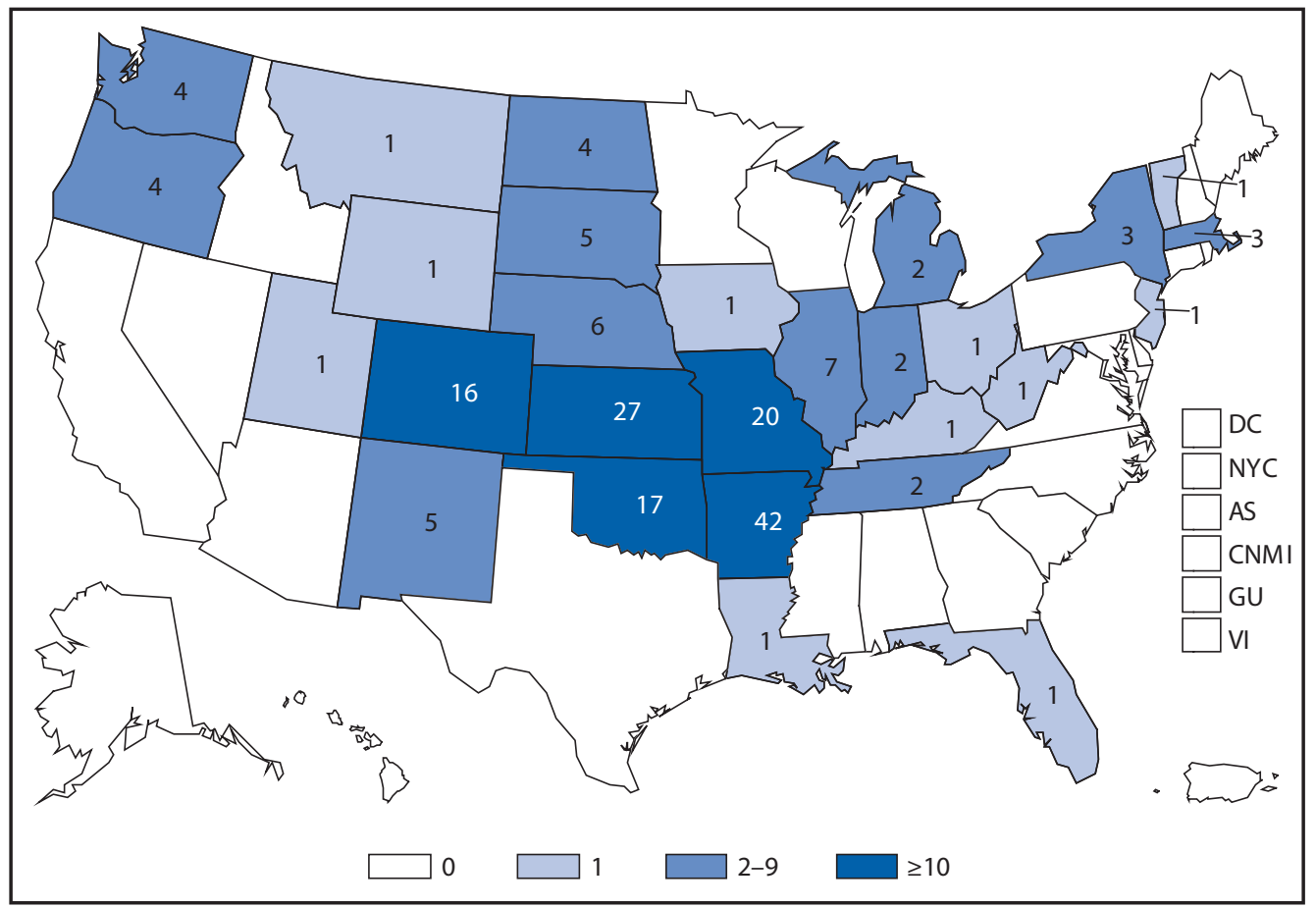

During 1990-2010, an average of 125 cases of tularemia were reported in the United States each year. Since 2011, the number of reported cases has been above this historical average. Most cases are reported from south-central states. In 2014, Colorado reported a much higher number of cases than in previous years. 
TYPHOID FEVER. Incidence* of reported cases, by year — United States, 1984-2014

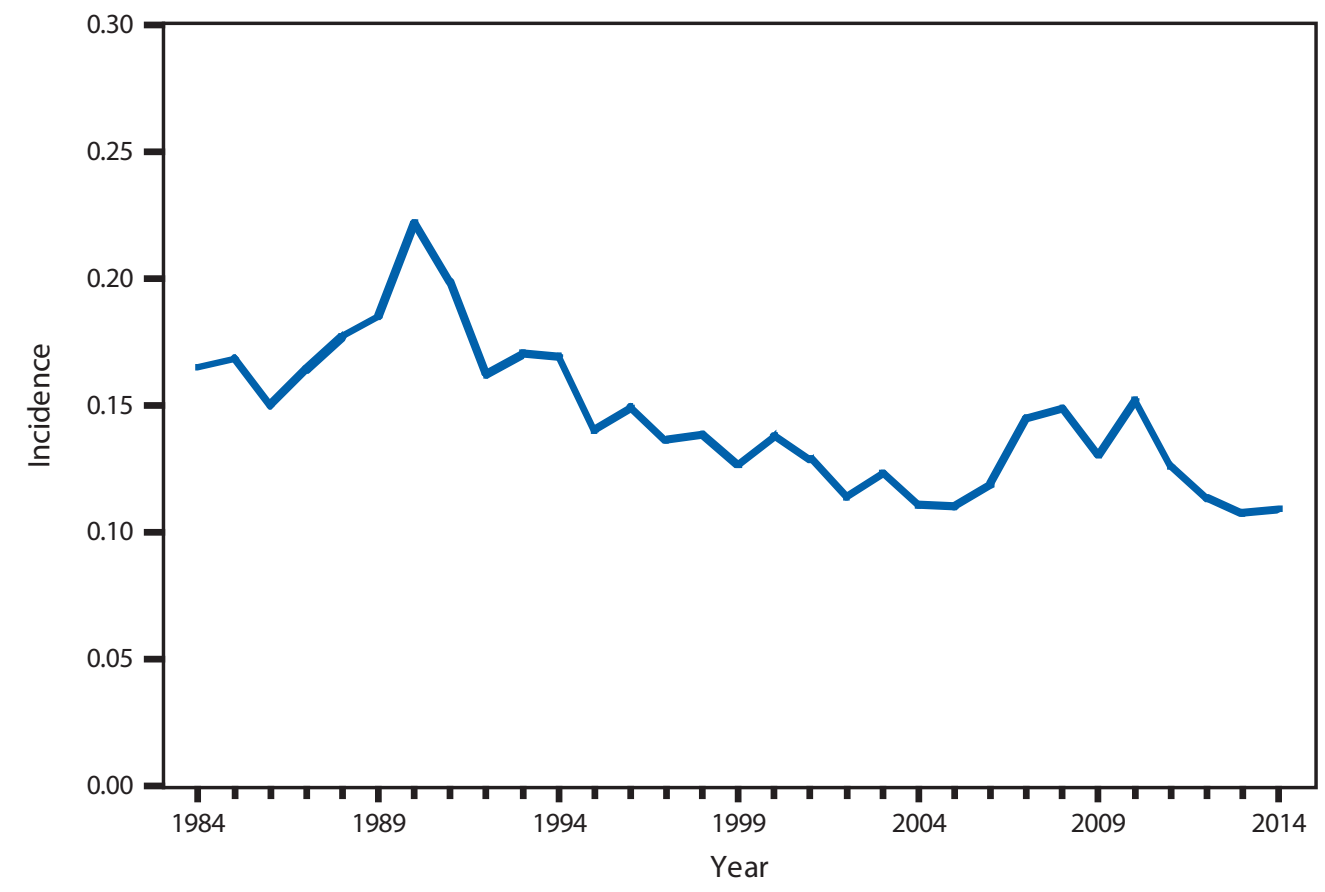

* Per 100,000 population.

In the United States, typhoid fever continues to occur primarily among travelers to countries where typhoid fever is endemic, for whom vaccination against typhoid fever is recommended. During the preceding 30 years, the annual number of typhoid fever cases peaked in 1990 (552 cases) and then declined to a low of 321 cases in 2002. Case counts then returned to levels observed in the early 1990s and increased 3\% from 338 in 2013 to 349 in 2014. 
VARICELLA (CHICKENPOX). Number of reported cases — Illinois, Michigan, Texas, and West Virginia, 1992-2014

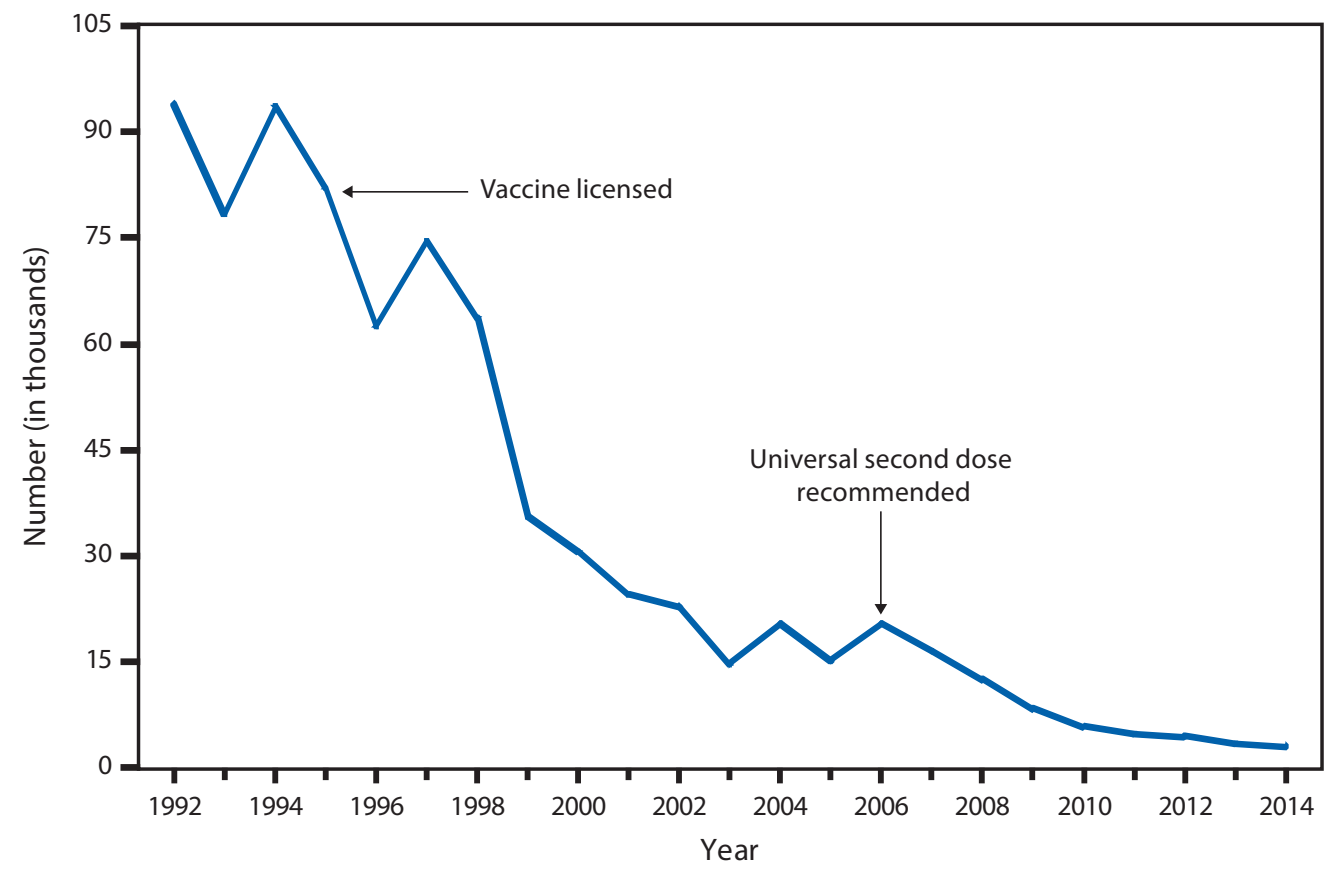

In four states (Illinois, Michigan, Texas, and West Virginia), the number of varicella cases reported in 2014 was 19\% lower than 2013, 85\% lower than the average annual number reported during the mature 1-dose varicella vaccination era of $2000-2006$, and $96 \%$ lower than the average annual number reported during the prevaccine years of 1993-1995. 
VIBRIOSIS. Number of reported cases — United States and U.S. territories, 2014

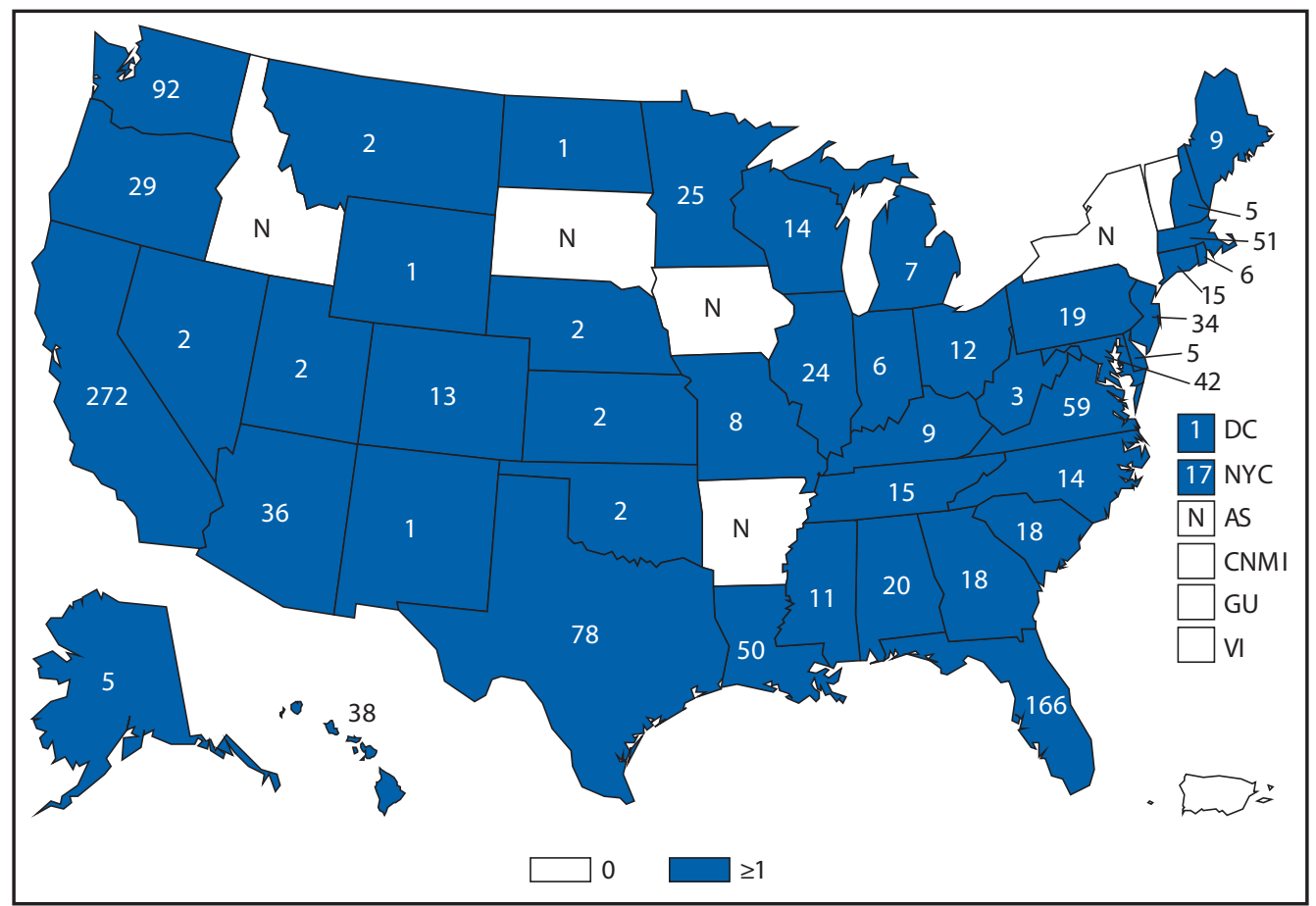

Abbreviation: $\mathrm{N}=$ not reportable.

In 2014, a total of 1,261 cases of vibriosis were reported. California, Florida, Washington, and Texas reported the highest numbers of cases. 


\section{Selected Reading for 2014}

\section{General}

Adams DA, Jajosky RA, Ajani U, et al. Summary of notifiable diseasesUnited States, 2012. MMWR Morb Mortal Wkly Rep 2014;61:1-121.

Adekoya N, Truman BI, Ajani UA. Completeness of reporting of race and ethnicity data in the Nationally Notifiable Diseases Surveillance System, United States, 2006-2010. J Public Health Manag Pract 2014;21:16.

Armstrong KE, McNabb SJ, Ferland LD, et al. Capacity of public health surveillance to comply with revised international health regulations, USA. Emerg Infect Dis 2010;16:804-8. http://dx.doi.org/10.3201/ eid1605.091127

Beltran VM, Harrison KM, Hall HI, Dean HD. Collection of social determinant of health measures in U.S. national surveillance systems for HIV, viral hepatitis, STDs, and TB. Public Health Rep 2011;126(Suppl 3):41-53.

Blau DM, Clark SC, Nolte KB. Infectious disease surveillance by medical examiners and coroners. Emerg Infect Dis 2013;19:821-2. http://dx.doi. org/10.3201/eid1905.121661

Boehmer TK, Patnaik JL, Burnite SJ, Ghosh TS, Gershman K, Vogt RL. Use of hospital discharge data to evaluate notifiable disease reporting to Colorado's Electronic Disease Reporting System. Public Health Rep 2011;126:100-6.

Buehler JW, Hopkins RS, Overhage JM, Sosin DM, Tong V. Framework for evaluating public health surveillance systems for early detection of outbreaks: recommendations from the CDC Working Group. MMWR Recomm Rep 2004;53(No. RR-5).

CDC. Automated detection and reporting of notifiable diseases using electronic medical records versus passive surveillance-Massachusetts, June 2006-July 2007. MMWR Morb Mortal Wkly Rep 2008;57:373-6.

CDC. CDC's vision for public health surveillance in the 21 st century. MMWR Suppl 2012;2012:61 (July 27, 2012).

CDC. Comparison of provisional with final notifiable disease case countsNational Notifiable Diseases Surveillance System, 2009. MMWR Morb Mortal Wkly Rep 2013;62:747-51.

CDC. Framework for program evaluation in public health. MMWR Recomm Rep 1999;48(No. RR-11):1-40.

Adekoya N, Truman B, Landen M. Incidence of notifiable diseases among American Indians/Alaska Natives-United States, 2007-2011. MMWR Morb Mortal Wkly Rep 2015;64:16-9.

CDC. Manual for the surveillance of vaccine-preventable diseases 5th Edition. Atlanta, GA: US Department of Health and Human Services; CDC, 2012. http://www.cdc.gov/vaccines/pubs/surv-manual/index.html

CDC. NCHHSTP Atlas. US Department of Health and Human Services; CDC. http://www.cdc.gov/nchhstp/atlas

National Electronic Disease Surveillance System Working Group. National Electronic Disease Surveillance System (NEDSS): a standards-based approach to connect public health and clinical medicine. J Public Health Manag Pract 2001;7:43-50. http://dx.doi. org/10.1097/00124784-200107060-00005

CDC. Changes in presentation of data from the National Notifiable Diseases Surveillance System-January 13, 2006. MMWR Morb Mortal Wkly Rep 2006;55:13-4.

CDC. National Notifiable Diseases Surveillance System (NNDSS). Atlanta, GA: US Department of Health and Human Services; CDC. https:// wwwn.cdc.gov/nndss

CDC. NNDSS Modernization initiative (NMI). Atlanta, GA: US Department of Health and Human Services; CDC. http://www.cdc. gov/nmi/index.html
CDC. Potential effects of electronic laboratory reporting on improving timeliness of infectious disease notification-Florida, 2002-2006. MMWR Morb Mortal Wkly Rep 2008;57:1325-8.

CDC. Progress in increasing electronic reporting of laboratory results to public health agencies-United States, 2013. MMWR Morb Mortal Wkly Rep 2013;62:797-999.

CDC. Reporting race and ethnicity data-National Electronic Telecommunications System for Surveillance, 1994-1997. MMWR Morb Mortal Wkly Rep 1999;48:305-12.

CDC. State electronic disease surveillance systems_-United States, 2007 and 2010. MMWR Morb Mortal Wkly Rep 2011;60:1421-3.

German RR, Lee LM, Horan JM, Milstein RL, Pertowski CA, Waller MN. Updated guidelines for evaluating public health surveillance systems: recommendations from the Guidelines Working Group. MMWR Recomm Rep 2001;50(No. RR-13).

Lamb E, Satre J, Hurd-Kundeti G, et al. Update on progress in electronic reporting of laboratory results to public health agencies-United States, 2014. MMWR Morb Mortal Wkly Rep 2015;64:328-30.

CDC. Use of race and ethnicity in public health surveillance: summary of the CDC/ATSDR workshop. MMWR Recomm Rep 1993;42(No. RR-10).

Chang MH, Glynn MK, Groseclose SL. Endemic, notifiable bioterrorismrelated diseases, United States, 1992-1999. Emerg Infect Dis 2003;9:55664. http://dx.doi.org/10.3201/eid0905.020477

Cronquist AB, Mody RK, Atkinson R, et al. Impacts of culture-independent diagnostic practices on public health surveillance for bacterial enteric pathogens. Clin Infect Dis 2012;54(Suppl 5):S432-9. http://dx.doi. org/10.1093/cid/cis267

Dato V, Wagner MM, Fapohunda A. How outbreaks of infectious disease are detected: a review of surveillance systems and outbreaks. Public Health Rep 2004;119:464-71. http://dx.doi.org/10.1016/j.phr.2004.07.003

Dixon BE, Siegel JA, Oemig TV, Grannis SJ. Electronic health information quality challenges and interventions to improve public health surveillance data and practice. Public Health Rep 2013;128:546-53.

Doyle TJ, Glynn MK, Groseclose SL. Completeness of notifiable infectious disease reporting in the United States: an analytical literature review. Am J Epidemiol 2002;155:866-74. http://dx.doi.org/10.1093/aje/155.9.866

Edelstein M, Heymann DL, Giesecke J, Weinberg J. Validity of International Health Regulations in reporting emerging infectious diseases. Emerg Infect Dis 2012;18:1115-20. http://dx.doi.org/10.3201/eid1807.111608

Effler P, Ching-Lee M, Bogard A, Ieong MC, Nekomoto T, Jernigan D. Statewide system of electronic notifiable disease reporting from clinical laboratories: comparing automated reporting with conventional methods. JAMA 1999;282:1845-50. http://dx.doi.org/10.1001/jama.282.19.1845

Fairchild A, Bayer R, Colgrove J. Privacy and public health surveillance: the enduring tension. Virtual Mentor 2007;9:838-41. http://dx.doi. org/10.1001/virtualmentor.2007.9.12.mhst1-0712

Frieden TR. A framework for public health action: the health impact pyramid. Am J Public Health 2010;100:590-5. http://dx.doi. org/10.2105/AJPH.2009.185652

Friedlin J, Grannis S, Overhage JM. Using natural language processing to improve accuracy of automated notifiable disease reporting. AMIA Symposium Proceedings 2008:207-11.

German RR. Sensitivity and predictive value positive measurements for public health surveillance systems. Epidemiology 2000;11:720-7. http:// dx.doi.org/10.1097/00001648-200011000-00020

Government Accountability Office. Emerging infectious diseases: review of state and federal disease surveillance efforts. Washington, DC: Government Accountability Office; 2004. GAO-04-877. http://www. gao.gov/new.items/d04877.pdf 
Gubernot DM, Boyer BL, Moses MS. Animals as early detectors of bioevents: veterinary tools and a framework for animal-human integrated zoonotic disease surveillance. Public Health Rep 2008;123:300-15.

Hagmann SH, Han PV, Stauffer WM, et al. Travel-associated disease among US residents visiting US GeoSentinel clinics after return from international travel. Fam Pract 2014;31:678-87. http://dx.doi. org/10.1093/fampra/cmu063

Heymann DL, editor. Control of communicable diseases manual. 20th ed. Washington, DC: American Public Health Association; 2014.

Hopkins RS. Design and operation of state and local infectious disease surveillance systems. J Public Health Manag Pract 2005;11:184-90. http://dx.doi.org/10.1097/00124784-200505000-00002

Jajosky RA, Groseclose SL. Evaluation of reporting timeliness of public health surveillance systems for infectious diseases. BMC Public Health 2004;4:29. http://dx.doi.org/10.1186/1471-2458-4-29

Kleinman KP, Abrams AM. Assessing the utility of public health surveillance using specificity, sensitivity, and lives saved. Stat Med 2008;27:4057-68. http://dx.doi.org/10.1002/sim.3269

Krause G, Brodhun B, Altmann D, Claus H, Benzler J. Reliability of case definitions for public health surveillance assessed by Round-Robin test methodology. BMC Public Health 2006;6:129. http://dx.doi. org/10.1186/1471-2458-6-129

Lazarus R, Klompas M, Campion FX, et al. Electronic Support for Public Health: validated case finding and reporting for notifiable diseases using electronic medical data. J Am Med Inform Assoc 2009;16:18-24. http:// dx.doi.org/10.1197/jamia.M2848

Lee LM, Teutsch SM, Thacker SB, St Louis ME, editors. Principles and practice of public health surveillance. 3rd ed. New York, NY: Oxford University Press; 2010:1-17.

Lee LM, Thacker SB. The cornerstone of public health practice: public health surveillance, 1961-2011. In: Public health then and now: celebrating 50 years of MMWR at CDC. MMWR Supp 2011;60(Oct. 7, 2011).

M'ikanatha NM, Iskander J. Concepts and Methods in Infectious Disease Surveillance. Malden, MA: Wiley; 2014.

M'ikanatha NM, Lynfield R, Van Beneden CA, de Valk H. Infectious disease surveillance, 2nd edition. Malden, MA: Wiley; 2013.

Nguyen TQ, Thorpe L, Makki HA, Mostashari F. Benefits and barriers to electronic laboratory results reporting for notifiable diseases: the New York City Department of Health and Mental Hygiene experience. Am J Public Health 2007;97(Suppl 1):S142-5. http://dx.doi.org/10.2105/ AJPH.2006.098996

Office of the National Coordinator for Health Information Technology. Federal health information technology strategic plan 2011-2015. Washington, DC: US Department of Health and Human Services; ONC. https:/www.healthit.gov/sites/default/files/utility/final-federal-health-itstrategic-plan-0911.pdf

Overhage JM, Grannis S, McDonald CJ. A comparison of the completeness and timeliness of automated electronic laboratory reporting and spontaneous reporting of notifiable conditions. Am J Public Health 2008;98:344-50. http://dx.doi.org/10.2105/AJPH.2006.092700

Pickering LK, editor. Red Book: 2015 Report of the Committee on Infectious Diseases. 30th ed. Elk Grove Village, IL: American Academy of Pediatrics; 2015.

Roush SW, Murphy TV. Historical comparisons of morbidity and mortality for vaccine-preventable diseases in the United States. JAMA 2007;298:2155-63. http://dx.doi.org/10.1001/jama.298.18.2155

Scallan E, Hoekstra RM, Angulo FJ, et al. Foodborne illness acquired in the United States-major pathogens. Emerg Infect Dis 2011;17:7-15. http://dx.doi.org/10.3201/eid1701.P11101

Sickbert-Bennett EE, Weber DJ, Poole C, MacDonald PD, Maillard JM. Completeness of communicable disease reporting, North Carolina, USA, 1995-1997 and 2000-2006. Emerg Infect Dis 2011;17:23-9. http:// dx.doi.org/10.3201/eid1701.100660
Silk BJ, Berkelman RL. A review of strategies for enhancing the completeness of notifiable disease reporting. J Public Health Manag Pract 2005;11:191-200. http://dx.doi.org/10.1097/00124784-200505000-00003

Struelens MJ, Brisse S. From molecular to genomic epidemiology: transforming surveillance and control of infectious diseases. Euro Surveill 2013; 18:203-86.

Vogt RL, Spittle R, Cronquist A, Patnaik JL. Evaluation of the timeliness and completeness of a Web-based notifiable disease reporting system by a local health department. J Public Health Manag Pract 2006;12:540-4. http://dx.doi.org/10.1097/00124784-200611000-00007

\section{Anthrax}

Bower W, Hendricks K, Pillai S, Guarnizo J, Meaney-Delman D. Clinical framework and medical countermeasure use during an anthrax masscasualty incident. MMWR Recomm Rep 2015;64(No. RR-4).

Bradley JS, Peacock G, Krug SE, et al. Pediatric anthrax clinical management. Pediatrics 2014;133:e1411-36. http://dx.doi.org/10.1542/ peds.2014-0563

Hendricks KA, Wright ME, Shadomy SV, et al. Centers for disease control and prevention expert panel meetings on prevention and treatment of anthrax in adults. Emerg Infect Dis 2014;20:20. http://dx.doi. org/10.3201/eid2002.130687

Meaney-Delman D, Zotti ME, Creanga AA, et al. Special considerations for prophylaxis for and treatment of anthrax in pregnant and postpartum women. Emerg Infect Dis 2014;20:20. http://dx.doi.org/10.3201/ eid2002.130611

\section{Domestic Arboviral, Neuroinvasive and Nonneuroinvasive}

Gaensbauer JT, Lindsey NP, Messacar K, Staples JE, Fischer M. Neuroinvasive arboviral disease in the United States: 2003 to 2012. Pediatrics 2014;134:e642-50. http://dx.doi.org/10.1542/peds.2014-0498

Hahn MB, Monaghan AJ, Hayden MH, et al. Meteorological conditions associated with increased incidence of West Nile virus disease in the United States, 2004-2012. Am J Trop Med Hyg 2015;92:1013-22. http:// dx.doi.org/10.4269/ajtmh.14-0737

Lindsey NP, Lehman JA, Staples JE, Fischer M. West Nile virus and other nationally notifiable arboviral diseases-United States, 2014. MMWR Morb Mortal Wkly Rep 2015;64:929-34. http://dx.doi.org/10.15585/ mmwr.mm6434a1

Lindsey NP, Prince HE, Kosoy O, et al. Chikungunya virus infections among travelers-United States, 2010-2013. Am J Trop Med Hyg 2015;92:82-7. http://dx.doi.org/10.4269/ajtmh.14-0442

Lindsey NP, Staples JE, Delorey MJ, Fischer M. Lack of evidence of increased West Nile virus disease severity in the United States in 2012. Am J Trop Med Hyg 2014;90:163-8. http://dx.doi.org/10.4269/ajtmh.13-0432

Lindsey NP, Staples JE, Lehman JA, Fischer M. Surveillance for human West Nile virus disease-United States, 1999-2008. MMWR Surveill Summ 2010;59(No. SS-2).

Pastula DM, Hoang Johnson DK, White JL, Dupuis AP 2nd, Fischer M, Staples JE. Jamestown Canyon virus disease in the United States - 2000-2013. Am J Trop Med Hyg 2015;93:384-9. http://dx.doi.org/10.4269/ ajtmh.15-0196

Reimann CA, Hayes EB, DiGuiseppi C, et al. Epidemiology of neuroinvasive arboviral disease in the United States, 1999-2007. Am J Trop Med Hyg 2008;79:974-9.

Ruktanonchai DJ, Stonecipher S, Lindsey N, et al. Effect of aerial insecticide spraying on West Nile virus disease-north-central Texas, 2012. Am J Trop Med Hyg 2014;91:240-5. http://dx.doi.org/10.4269/ ajtmh.14-0072 
Staples JE, Shankar MB, Sejvar JJ, Meltzer MI, Fischer M. Initial and longterm costs of patients hospitalized with West Nile virus disease. Am J Trop Med Hyg 2014;90:402-9. http://dx.doi.org/10.4269/ajtmh.13-0206

Winston DJ, Vikram HR, Rabe IB, et al. Donor-derived West Nile virus infection in solid organ transplant recipients: report of four additional cases and review of clinical, diagnostic, and therapeutic features. Transplantation 2014;97:881-9. http://dx.doi.org/10.1097/ TP.0000000000000024

Yendell SJ, Fischer M, Staples JE. Colorado tick fever in the United States, 2002-2012. Vector Borne Zoonotic Dis 2015;15:311-6. http://dx.doi. org/10.1089/vbz.2014.1755

Yendell SJ, Taylor J, Biggerstaff BJ, Tabony L, Staples JE, Fischer M. Use of laboratory reports as predictors of West Nile virus disease cases-Texas, 2008-2012. Epidemiol Infect 2015;143:419-26. http://dx.doi. org/10.1017/S0950268814000909

\section{Babesiosis}

CDC. Babesiosis surveillance-18 States, 2011. MMWR Morb Mortal Wkly Rep 2012;61:505-9.

Herwaldt BL, Linden JV, Bosserman E, Young C, Olkowska D, Wilson M. Transfusion-associated babesiosis in the United States: a description of cases. Ann Intern Med 2011;155:509-19. http://dx.doi. org/10.7326/0003-4819-155-8-201110180-00362

Joseph JT, Purtill K, Wong SJ, et al. Vertical transmission of Babesia microti, United States. Emerg Infect Dis 2012;18:1318-21. http://dx.doi. org/10.3201/eid1808.110988

Acosta ME, Ender PT, Smith EM, Jahre JA. Babesia microti infection, eastern Pennsylvania, USA. Emerg Infect Dis 2013;19:1105-7. http://dx.doi. org/10.3201/eid1907.121593

Vannier E, Krause PJ. Human babesiosis. N Engl J Med 2012;366:2397407. http://dx.doi.org/10.1056/NEJMra1202018

\section{Botulism}

Arnon SS, Barzilay EJ. Clostridial Infections: Botulism and Infant Botulism. In: Pickering LK, Baker CJ, Kimberlin DW, Long SS, eds. The Red Book: 2009 report of the Committee on Infectious Diseases. Elk Grove Village: American Academy of Pediatrics; 2009:259-62.

CDC. Infant botulism-New York City, 2001-2002. MMWR Morb Mortal Wkly Rep 2003;52:21-4.

Fagan RP, McLaughlin JB, Castrodale LJ, et al. Endemic foodborne botulism among Alaska Native persons-Alaska, 1947-2007. Clin Infect Dis 2011;52:585-92. http://dx.doi.org/10.1093/cid/ciq240

Newkirk RW, Hedberg CW. Rapid detection of foodborne botulism outbreaks facilitated by epidemiological linking of cases: implications for food defense and public health response. Foodborne Pathog Dis 2012;9:150-5. http://dx.doi.org/10.1089/fpd.2011.0971

Rao A, Jackson KA. Botulism. In: DL Heymann, ed. Control of communicable diseases manual, Washington DC: American Public Health Association Press; 2015.

Shapiro RL, Hatheway C, Becher J, Swerdlow DL. Botulism surveillance and emergency response. A public health strategy for a global challenge. JAMA 1997;278:433-5. http://dx.doi.org/10.1001/ jama.1997.03550050095041

Shapiro RL, Hatheway C, Swerdlow DL. Botulism in the United States: a clinical and epidemiologic review. Ann Intern Med 1998;129:221-8 http://dx.doi.org/10.7326/0003-4819-129-3-199808010-00011

Sobel J. Botulism. Clin Infect Dis 2005;41:1167-73. http://dx.doi. org/10.1086/444507

Sobel J, Tucker N, Sulka A, McLaughlin J, Maslanka S. Foodborne botulism in the United States, 1990-2000. Emerg Infect Dis 2004;10:1606-11. http://dx.doi.org/10.3201/eid1009.030745
Werner SB, Passaro D, McGee J, Schechter R, Vugia DJ. Wound botulism in California, 1951-1998: recent epidemic in heroin injectors. Clin Infect Dis 2000;31:1018-24. http://dx.doi.org/10.1086/318134

\section{Brucellosis}

Ashford DA, di Pietra J, Lingappa J, et al. Adverse events in humans associated with accidental exposure to the livestock brucellosis vaccine RB51. Vaccine 2004;22:3435-9. http://dx.doi.org/10.1016/j.vaccine.2004.02.041

CDC. Brucellosis (Brucella melitensis, abortus, suis, and canis). Atlanta, GA: US Department of Health and Human Services, CDC; 2012.

CDC. Brucellosis. Atlanta, GA: US Department of Health and Human Services, CDC; 2010. http://www.cdc.gov/brucellosis

CDC. Brucellosis case definition. Atlanta, GA: US Department of Health and Human Services, CDC; 2010. https://wwwn.cdc.gov/nndss/ conditions/brucellosis/case-definition/2010

CDC. Brucella suis infection associated with feral swine hunting-three states, 2007-2008. MMWR Morb Mortal Wkly Rep 2009;58:618-21.

CDC. Public health consequences of a false-positive laboratory test result for Brucella-Florida, Georgia, and Michigan, 2005. MMWR Morb Mortal Wkly Rep 2008;57:603-5.

CDC. Laboratory-acquired brucellosis-Indiana and Minnesota, 2006. MMWR Morb Mortal Wkly Rep 2008;57:39-42.

Chomel BB, DeBess EE, Mangiamele DM, et al. Changing trends in the epidemiology of human brucellosis in California from 1973 to 1992: a shift toward foodborne transmission. J Infect Dis 1994;170:1216-23. http://dx.doi.org/10.1093/infdis/170.5.1216

Glynn MK, Lynn TV. Brucellosis. J Am Vet Med Assoc 2008;233:900-8. http://dx.doi.org/10.2460/javma.233.6.900

Traxler RM, Lehman MW, Bosserman EA, Guerra MA, Smith TL. A literature review of laboratory-acquired brucellosis. J Clin Microbiol 2013;51:3055-62. http://dx.doi.org/10.1128/JCM.00135-13

Yagupsky P, Baron EJ. Laboratory exposures to brucellae and implications for bioterrorism. Emerg Infect Dis 2005;11:1180-5. http://dx.doi. org/10.3201/eid1108.041197

\section{Chlamydia}

CDC. Sexually transmitted disease surveillance, 2014. Atlanta, GA: US Department of Health and Human Services, CDC; 2015.

LeFevre ML. Screening for Chlamydia and gonorrhea: U.S. Preventive Services Task Force recommendation statement. Ann Intern Med 2014;161:902-10. http://dx.doi.org/10.7326/M14-1981

Satterwhite CL, Torrone E, Meites E, et al. Sexually transmitted infections among US women and men: prevalence and incidence estimates, 2008. Sex Transm Dis 2013;40:187-93. http://dx.doi.org/10.1097/ OLQ.0b013e318286bb53

Torrone E, Papp J, Weinstock H. Prevalence of Chlamydia trachomatis genital infection among persons aged 14-39 years-United States, 2007-2012. MMWR Morb Mortal Wkly Rep 2014;63:834-8.

\section{Cholera}

Besser RE, Feikin DR, Eberhart-Phillips JE, Mascola L, Griffin PM. Diagnosis and treatment of cholera in the United States. Are we prepared? JAMA 1994;272:1203-5. http://dx.doi.org/10.1001/ jama.1994.03520150071039

Loharikar A, Newton AE, Stroika S, et al. Cholera in the United States, 2001-2011: a reflection of patterns of global epidemiology and travel. Epidemiol Infect 2015;143:695-703. http://dx.doi.org/10.1017/ S0950268814001186

Mintz ED, Guerrant RL. A lion in our village-the unconscionable tragedy of cholera in Africa. New Engl J Med 2009;360:1061-3. 
Newton AE, Heiman KE, Schmitz A, et al. Cholera in United States associated with epidemic in Hispaniola. Emerg Infect Dis 2011;17:2166-8. http:// dx.doi.org/10.3201/eid1711.110808

Siddique AK, Nair GB, Alam M, et al. El Tor cholera with severe disease: a new threat to Asia and beyond. Epidemiol Infect 2010;138:347-52. http://dx.doi.org/10.1017/S0950268809990550

Steinberg EB, Greene KD, Bopp CA, Cameron DN, Wells JG, Mintz ED. Cholera in the United States, 1995-2000: trends at the end of the twentieth century. J Infect Dis 2001;184:799-802. http://dx.doi. org/10.1086/322989

Tappero JW, Tauxe RV. Lessons learned during public health response to cholera epidemic in Haiti and the Dominican Republic. Emerg Infect Dis 2011;17:2087-93. http://dx.doi.org/10.3201/eid1711.110827

World Health Organization. Cholera, 2012. Wkly Epidemiol Rec 2013;88:321-34.

\section{Coccidioidomycosis}

Blair JE, Chang YH, Cheng MR, et al. Characteristics of patients with mild to moderate primary pulmonary coccidioidomycosis. Emerg Infect Dis 2014;20:983-90. http://dx.doi.org/10.3201/eid2006.131842

Nguyen C, Barker BM, Hoover S, et al. Recent advances in our understanding of the environmental, epidemiological, immunological, and clinical dimensions of coccidioidomycosis. Clin Microbiol Rev 2013;26:505-25. http://dx.doi.org/10.1128/CMR.00005-13

Wilken JA, Sondermeyer G, Shusterman D, et al. Coccidioidomycosis among workers constructing solar power farms, California, USA, 2011-2014. Emerg Infect Dis 2015;21:1997-2005. http://dx.doi.org/10.3201/ eid2111.150129

\section{Cryptosporidiosis}

CDC. CryptoNet: Molecular-based tracking to better understand U.S. Cryptosporidium transmission. Atlanta, GA: US Department of Health and Human Services, CDC; 2013. http://www.cdc.gov/parasites/crypto/ cryptonet.html

CDC. DPDx: Laboratory identification of parasitic diseases of public health concern: stool specimens. Atlanta, GA: US Department of Health and Human Services, CDC; 2013. http://www.cdc.gov/dpdx/ diagnosticProcedures/stool/antigendetection.html

Hlavsa MC, Roberts VA, Kahler AM, et al. Outbreaks of illness associated with recreational water-United States, 2011-2012. MMWR Morb Mortal Wkly Rep 2015;64:668-72.

Painter JE, Hlavsa MC, Collier SA, Xiao L, Yoder JS. Cryptosporidiosis surveillance-United States, 2011-2012. MMWR Surveill Summ 2015;64(No. SS-3).

Roy SL, DeLong SM, Stenzel SA, et al. Risk factors for sporadic cryptosporidiosis among immunocompetent persons in the United States from 1999 to 2001. J Clin Microbiol 2004;42:2944-51. http://dx.doi. org/10.1128/JCM.42.7.2944-2951.2004

Painter JE, Gargano JW, Yoder JS, Collier SA, Hlavsa MC. Evolving epidemiology of reported cryptosporidiosis cases in the United States, 1995-2012. Epidemiol Infect 2016;144:1792-802. http://dx.doi. org/10.1017/S0950268815003131

\section{Cyclosporiasis}

Abanyie F, Harvey RR, Harris JR, et al. 2013 multistate outbreaks of Cyclospora cayetanensis infections associated with fresh produce: focus on the Texas investigations. Epidemiol Infect 2015;143:3451-8. http:// dx.doi.org/10.1017/S0950268815000370
Hall RL, Jones JL, Herwaldt BL. Surveillance for laboratory-confirmed sporadic cases of cyclosporiasis-United States, 1997-2008. MMWR Surveill Summ 2011;60(No. SS-2):1-11.

Hall RL, Jones JL, Hurd S, Smith G, Mahon BE, Herwaldt BL. Populationbased active surveillance for Cyclospora infection-United States, Foodborne Diseases Active Surveillance Network (FoodNet), 1997-2009. Clin Infect Dis 2012;54(Suppl 5):S411-7. http://dx.doi.org/10.1093/ $\mathrm{cid} / \mathrm{cis} 049$

Herwaldt BL. Cyclospora cayetanensis: a review, focusing on the outbreaks of cyclosporiasis in the 1990s. Clin Infect Dis 2000;31:1040-57. http:// dx.doi.org/10.1086/314051

Herwaldt BL. The ongoing saga of U.S. outbreaks of cyclosporiasis associated with imported fresh produce: what Cyclospora cayetanensis has taught us and what we have yet to learn. In: Institute of Medicine. Addressing foodborne threats to health: policies, practices, and global coordination. Washington, DC: The National Academies Press; 2006:85-115,133-40.

\section{Dengue}

Simmons CP, Farrar JJ, Nguyen V, Wills B. Dengue. N Engl J Med 2012;366:1423-32. http://dx.doi.org/10.1056/NEJMra1110265

\section{Diphtheria}

Dewinter LM, Bernard KA, Romney MG. Human clinical isolates of Corynebacterium diphtheriae and Corynebacterium ulcerans collected in Canada from 1999 to 2003 but not fitting reporting criteria for cases of diphtheria. J Clin Microbiol 2005;43:3447-9. http://dx.doi.org/10.1128/ JCM.43.7.3447-3449.2005

Tiwari TW, Wharton M. Diphtheria toxoid In: Plotkin O, Orenstein W, Offitt P, eds. Vaccines 2013.

Wagner KS, Stickings P, White JM, et al. A review of the international issues surrounding the availability and demand for diphtheria antitoxin for therapeutic use. Vaccine 2009;28:14-20. http://dx.doi.org/10.1016/j. vaccine.2009.09.094

Wagner KS, White JM, Crowcroft NS, De Martin S, Mann G, Efstratiou A. Diphtheria in the United Kingdom, 1986-2008: the increasing role of Corynebacterium ulcerans. Epidemiol Infect 2010;138:1519-30. http:// dx.doi.org/10.1017/S0950268810001895

Wagner KS, White JM, Lucenko I, et al. Diphtheria in the postepidemic period, Europe, 2000-2009. Emerg Infect Dis 2012;18:217-25. http:// dx.doi.org/10.3201/eid1802.110987

Zakikhany K, Efstratiou A. Diphtheria in Europe: current problems and new challenges. Future Microbiol 2012;7:595-607. http://dx.doi. org/10.2217/fmb.12.24

\section{Ehrlichiosis and Anaplasmosis}

CDC. Diagnosis and management of tickborne rickettsial diseases: Rocky Mountain spotted fever and other spotted fever group rickettsioses, ehrlichioses, and anaplasmosis_-United States: a practical guide for health care and public health professionals. MMWR Recomm Rep 2016;65(No. RR-2).

Dahlgren FS, Heitman KN, Drexler NA, Massung RF, Behravesh CB. Human granulocytic anaplasmosis in the United States from 2008 to 2012: a summary of national surveillance data. Am J Trop Med Hyg 2015;93:66-72. http://dx.doi.org/10.4269/ajtmh.15-0122

Dahlgren FS, Heitman KN, Drexler NA, Massung RF, Behravesh CB. Undetermined ehrlichiosis and anaplasmosis in the United States, 2008-2012: a catch-all for passive surveillance. Am J Trop Med Hyg 2016;94:299-301. http://dx.doi.org/10.4269/ajtmh.15-0691

Johnson DK, Schiffman EK, Davis JP, et al. Human infection with Ehrlichia muris-like pathogen, United States, 2007-2013. Emerg Infect Dis 2015;21:1794-9. http://dx.doi.org/10.3201/eid2110.150143 
Nichols Heitman K, Dahlgren FS, Drexler NA, Massung RF, Behravesh CB. Increasing incidence of Ehrlichiosis in the United States: a summary of national surveillance of Ehrlichia chaffeensis and Ehrlichia ewingii infections in the United States, 2008-2012. Am J Trop Med Hyg 2016;94:52-60. http://dx.doi.org/10.4269/ajtmh.15-0540

\section{Giardiasis}

Cantey PT, Roy S, Lee B, et al. Study of nonoutbreak giardiasis: novel findings and implications for research. Am J Med 2011;124:1175.e1-8. http://dx.doi.org/10.1016/j.amjmed.2011.06.012

CDC. Surveillance for travel-related disease-GeoSentinel Surveillance System, United States, 1997-2011. MMWR Surveill Summ 2013;62(No. SS-3).

Clinical and Laboratory Standards Institute. Procedures for the recovery and identification of parasites from the intestinal tract; approved guideline. CLSI document M28-A2 Second Edition. Wayne, PA: Clinical and Laboratory Standards Institute; 2005.

Anonymous. Drugs for parasitic infections. Treat Guidel Med Lett 2010;8:e5.

\section{Gonorrhea}

CDC. Sexually transmitted disease surveillance, 2014. Atlanta, GA: US Department of Health and Human Services, CDC; 2015.

CDC. Sexually transmitted disease treatment guidelines, 2015. MMWR Recom Rep 2015:64(No. RR-3).

LeFevre ML. Screening for Chlamydia and gonorrhea: U.S. Preventive Services Task Force recommendation statement. Ann Intern Med 2014;161:902-10. http://dx.doi.org/10.7326/M14-1981

Torrone EA, Johnson RE, Tian LH, Papp JR, Datta SD, Weinstock HS. Prevalence of Neisseria gonorrhoeae among persons 14 to 39 years of age, United States, 1999 to 2008. Sex Transm Dis 2013;40:202-5. http:// dx.doi.org/10.1097/OLQ.0b013e31827c5a71

\section{Haemophilus influenzae}

Blain, A, MacNeil, J, Wang, X et al. Invasive Haemophilus influenzae Disease in Adults $\geq 65$ Years, United States, 2011. Open Forum Infect Dis 2014; 1:ofuo44.

Briere EC, Jackson M, Shah SG, et al. Haemophilus influenzae type b disease and vaccine booster dose deferral, United States, 1998-2009. Pediatrics 2012;130:414-20. http://dx.doi.org/10.1542/peds.2012-0266

Briere EC, Rubin L, Moro PL, Cohn A, Clark T, Messonnier N. Prevention and control of haemophilus influenzae type $\mathrm{b}$ disease: recommendations of the advisory committee on immunization practices (ACIP). MMWR Recomm Rep 2014;63(No. RR-1).

MacNeil JR, Cohn AC, Farley M, et al. Current epidemiology and trends in invasive Haemophilus influenzae disease-United States, 1989-2008. Clin Infect Dis 2011;53:1230-6. http://dx.doi.org/10.1093/cid/cir735

Schuchat A, Messonnier NR. From pandemic suspect to the postvaccine era: the Haemophilus influenzae story. Clin Infect Dis 2007;44:817-9. http:// dx.doi.org/10.1086/511886

\section{Hansen's Disease (Leprosy)}

Britton WJ, Lockwood DN. Leprosy. Lancet 2004;363:1209-19. http:// dx.doi.org/10.1016/S0140-6736(04)15952-7

Hartzell JD, Zapor M, Peng S, Straight T. Leprosy: a case series and review. South Med J 2004;97:1252-6. http://dx.doi.org/10.1097/01. SMJ.0000146549.63078.39

Hastings R, editor. Leprosy. 2nd ed. New York, NY: Churchill Livingstone; 1994.
Scollard DM, Adams LB, Gillis TP, Krahenbuhl JL, Truman RW, Williams DL. The continuing challenges of leprosy. Clin Microbiol Rev 2006;19:338-81. http://dx.doi.org/10.1128/CMR.19.2.338-381.2006

Scollard D, Stryjewska B. Epidemiology, microbiology, clinical manifestations, and diagnosis of leprosy. UpToDate 2015. http://www.uptodate.com/ contents/epidemiology-microbiology-clinical-manifestations-anddiagnosis-of-leprosy

Sharma R, Singh P, Loughry WJ, et al. Zoonotic leprosy in the Southeastern United States. Emerg Infect Dis 2015;21:2127-34. http://dx.doi. org/10.3201/eid2112.150501

Woodall P, Scollard D, Rajan L. Hansen disease among Micronesian and Marshallese persons living in the United States. Emerg Infect Dis 2011;17:1202-8. http://dx.doi.org/10.3201/eid1707.102036

Worobec SM. Current approaches and future directions in the treatment of leprosy. Res Rep Trop Med 2012;3:79-91 http://dx.doi.org/10.2147/ RRTM.S27395

\section{Hantavirus Pulmonary Syndrome}

Mills JN, Corneli A, Young JC, Garrison LE, Khan AS, Ksiazek TG. Hantavirus pulmonary syndrome-United States: updated recommendations for risk reduction. MMWR Recomm Rep 2002;51(No. RR-9).

Khan AS, Khabbaz RF, Armstrong LR, et al. Hantavirus pulmonary syndrome: the first 100 US cases. J Infect Dis 1996;173:1297-303. http:// dx.doi.org/10.1093/infdis/173.6.1297

Knust B, Rollin PE. Twenty-year summary of surveillance for human hantavirus infections, United States. Emerg Infect Dis 2013;19:1934-7. http://dx.doi.org/10.3201/eid1912.131217

MacNeil A, Ksiazek TG, Rollin PE. Hantavirus pulmonary syndrome, United States, 1993-2009. Emerg Infect Dis 2011;17:1195-201.

\section{Hemolytic Uremic Syndrome}

Gould LH, Demma L, Jones TF, et al. Hemolytic uremic syndrome and death in persons with Escherichia coli O157:H7 infection, foodborne diseases active surveillance network sites, 2000-2006. Clin Infect Dis 2009;49:1480-5. http://dx.doi.org/10.1086/644621

Mody RK, Gu W, Griffin PM, et al. Postdiarrheal hemolytic uremic syndrome in United States children: clinical spectrum and predictors of in-hospital death. J Pediatr 2015;166:1022-9. http://dx.doi. org/10.1016/j.jpeds.2014.12.064

Mody RK, Luna-Gierke RE, Jones TF, et al. Infections in pediatric postdiarrheal hemolytic uremic syndrome: factors associated with identifying shiga toxin-producing Escherichia coli. Arch Pediatr Adolesc Med 2012;166:902-9. http://dx.doi.org/10.1001/archpediatrics.2012.471

Ong KL, Apostal M, Comstock N, et al. Strategies for surveillance of pediatric hemolytic uremic syndrome: Foodborne Diseases Active Surveillance Network (FoodNet), 2000-2007. Clin Infect Dis 2012;54(Suppl 5):S424-31 http://dx.doi.org/10.1093/cid/cis208

Tarr PI, Gordon CA, Chandler WL. Shiga-toxin-producing Escherichia coli and haemolytic uraemic syndrome. Lancet 2005;365:1073-86.

\section{Hepatitis}

Bender TJ, Sharapov UM, Utah O, et al. Hepatitis B vaccine immunogenicity among adults vaccinated during an outbreak response in an assisted living facility-Virginia, 2010. Vaccine 2014;32:852-6. http://dx.doi. org/10.1016/j.vaccine.2013.12.018

Denniston MM, Jiles RB, Drobeniuc J, et al. Chronic hepatitis C virus infection in the United States, National Health and Nutrition Examination Survey 2003 to 2010. Ann Intern Med 2014;160:293-300. http://dx.doi.org/10.7326/M13-1133 
Gordon SC, Lamerato LE, Rupp LB, et al. Antiviral therapy for chronic hepatitis $B$ virus infection and development of hepatocellular carcinoma in a US population. Clin Gastroenterol Hepatol 2014;12:885-93. http:// dx.doi.org/10.1016/j.cgh.2013.09.062

Holmberg SD, Spradling PR, Moorman AC, Denniston MM. Hepatitis C in the United States. N Engl J Med 2013;368:1859-61. http://dx.doi. org/10.1056/NEJMp1302973

Klevens RM, Liu S, Roberts H, Jiles RB, Holmberg SD. Estimating acute viral hepatitis infections from nationally reported cases. Am J Public Health 2014;104:482;104:482-7. http://dx.doi.org/10.2105/ AJPH.2013.301601

Liu G, Holmberg SD, Kamili S, Xu F. Racial disparities in the proportion of current, unresolved hepatitis $\mathrm{C}$ virus infections in the United States, 2003-2010. Dig Dis Sci 2014;59:1950;59:1950-7. http://dx.doi. org/10.1007/s10620-014-3059-9

Liu SJ, Iqbal K, Shallow S, et al. Characterization of chronic hepatitis B cases among foreign-born persons in six population-based surveillance sites, United States 2001-2010. J Immigr Minor Health 2015;17:7-12. http://dx.doi.org/10.1007/s10903-014-0012-0

Ly KN, Roberts H, Williams RE, et al. Hepatitis B vaccination for healthcare personnel in American Samoa: pre-implementation survey for policy decision. Epidemiol Infect 2014;142:2610-5. http://dx.doi.org/10.1017/ S0950268813003506

Mahajan R, Xing J, Liu SJ, et al. Mortality among persons in care with hepatitis C virus infection: the Chronic Hepatitis Cohort Study (CHeCS), 2006-2010. Clin Infect Dis 2014;58:1055-61. http://dx.doi. org/10.1093/cid/ciu077

Middleman AB, Baker CJ, Kozinetz CA, et al. Duration of protection after infant hepatitis B vaccination series. Pediatrics 2014;133:e1500-7. http:// dx.doi.org/10.1542/peds.2013-2940

Roberts HW, Utuama OA, Klevens M, Teshale E, Hughes E, Jiles R. The contribution of viral hepatitis to the burden of chronic liver disease in the United States. Am J Gastroenterol 2014;109:387-93. http://dx.doi. org/10.1038/ajg.2013.477

Valdiserri RO, Khalsa J, Dan C, et al. Confronting the emerging epidemic of hepatitis $\mathrm{C}$ virus among young injection drug users. Am J Public Health 2014;104:816-21. http://dx.doi.org/10.2105/AJPH.2013.301812

Vijayadeva V, Spradling P, Moorman A, et al. Hepatitis B virus infection testing and prevalence among Asian and Pacific Islanders. Am J Manag Care 2014;20:e98-104.

\section{HIV Infection}

CDC. HIV Surveillance Report, 2014; 2015. http://www.cdc.gov/hiv/ library/reports/surveillance

CDC. Monitoring selected national HIV prevention and care objectives by using HIV surveillance data-United States and 6 dependent areas2013. HIV Surveillance Supplemental Report 2015;20(No.4). http:// www.cdc.gov/hiv/library/reports/surveillance/index.html

Schneider E, Whitmore S, Glynn KM, Dominguez K, Mitsch A, McKenna MT. Revised surveillance case definitions for HIV infection among adults, adolescents, and children aged $<18$ months and for HIV infection and AIDS among children aged 18 months to $<13$ years—United States, 2008. MMWR Recomm Rep 2008;57(No. RR-10).

CDC. Revised surveillance case definition for HIV infection-United States, 2014. MMWR Recomm Rep 2014;63(No. RR-3).

Cohen SM, Gray KM, Ocfemia MC, Johnson AS, Hall HI. The status of the National HIV Surveillance System, United States, 2013. Public Health Rep 2014;129:335-41.

Frieden TR, Foti KE, Mermin J. Applying public health principles to the HIV epidemic-How are we doing? N Engl J Med 2015;373:2281-7. http://dx.doi.org/10.1056/NEJMms1513641

\section{Influenza-Associated Pediatric Mortality}

Bhat N, Wright JG, Broder KR, et al. Influenza-associated deaths among children in the United States, 2003-2004. N Engl J Med 2005;353:255967. http://dx.doi.org/10.1056/NEJMoa051721

Blanton L, Peacock G, Cox C, Jhung M, Finelli L, Moore C. Neurologic disorders among pediatric deaths associated with the 2009 pandemic influenza. Pediatrics 2012;130:390-6. http://dx.doi.org/10.1542/ peds.2011-3343

Cox CM, Blanton L, Dhara R, Brammer L, Finelli L. 2009 Pandemic influenza A (H1N1) deaths among children-United States, 2009-2010. Clin Infect Dis 2011;52(Suppl 1):S69-74. http://dx.doi.org/10.1093/ $\mathrm{cid} / \mathrm{ciq} 011$

Counsel of State and Territorial Epidemiologists. Position statement 04-ID04: Influenza-associated pediatric mortality 2004. Atlanta, GA: Council of State and Territorial Epidemiologists; 2004. http://c.ymcdn.com/sites/ www.cste.org/resource/resmgr/PS/04-ID-04-FINAL.pdf

Counsel of State and Territorial Epidemiologists. Position statement 07-ID14: Influenza-associated pediatric mortality 2007. Atlanta, GA: Council of State and Territorial Epidemiologists; 2007. http://c.ymcdn.com/sites/ www.cste.org/resource/resmgr/PS/07-ID-14.pdf

Finelli L, Fiore A, Dhara R, et al. Influenza-associated pediatric mortality in the United States: increase of Staphylococcus aureus coinfection. Pediatrics 2008;122:805-11. http://dx.doi.org/10.1542/peds.2008-1336

Guarner J, Paddock CD, Shieh WJ, et al. Histopathologic and immunohistochemical features of fatal influenza virus infection in children during the 2003-2004 season. Clin Infect Dis 2006;43:132-40. http:// dx.doi.org/10.1086/505122

Peebles PJ, Dhara R, Brammer L, Fry AM, Finelli L. Influenzaassociated mortality among children-United States: 2007-2008. Influenza Other Respi Viruses 2011;5:25-31. http://dx.doi. org/10.1111/j.1750-2659.2010.00166.x

Quandelacy TM, Viboud C, Charu V, Lipsitch M, Goldstein E. Age- and sex-related risk factors for influenza-associated mortality in the United States between 1997-2007. Am J Epidemiol 2014;179:156-67. http:// dx.doi.org/10.1093/aje/kwt235

Wong KK, Jain S, Blanton L, et al. Influenza-associated pediatric deaths in the United States, 2004-2012. Pediatrics 2013;132:796-804. http:// dx.doi.org/10.1542/peds.2013-1493

\section{Invasive Pneumococcal Disease and Drug-Resistant Streptococcus pneumoniae}

CDC. Antibiotic resistance threats in the United States, 2013. http://www. cdc.gov/drugresistance/threat-report-2013

CDC. Use of 13-valent pneumococcal conjugate vaccine and 23-valent pneumococcal polysaccharide vaccine among children aged 6-18 years with immunocompromising conditions: recommendations of the Advisory Committee on Immunization Practices (ACIP). MMWR Morb Mortal Wkly Rep 2013;62:521-4.

CDC. Use of 13-valent pneumococcal conjugate vaccine and 23 -valent pneumococcal polysaccharide vaccine for adults with immunocompromising conditions: recommendations of the Advisory Committee on Immunization Practices (ACIP). MMWR Morb Mortal Wkly Rep 2012;61:816-9.

Kobayashi M, Bennett NM, Gierke R, et al. Intervals between PCV13 and PPSV23 vaccines: recommendations of the Advisory Committee on Immunization Practices (ACIP). MMWR Morb Mortal Wkly Rep 2015;64:944-7. http://dx.doi.org/10.15585/mmwr.mm6434a4

Nuorti JP, Whitney CG. Prevention of pneumococcal disease among infants and children-use of 13-valent pneumococcal conjugate vaccine and 23-valent pneumococcal polysaccharide vaccine: recommendations of the Advisory Committee on Immunization Practices (ACIP). MMWR Recomm Rep 2010;(No. RR-11). 
Tomczyk S, Bennett NM, Stoecker C, et al. Use of 13-valent pneumococcal conjugate vaccine and 23 -valent pneumococcal polysaccharide vaccine among adults aged $\geq 65$ years: recommendations of the Advisory Committee on Immunization Practices (ACIP). MMWR Morb Mortal Wkly Rep 2014;63:822-5.

\section{Legionellosis}

American Society of Heating, Refrigerating and Air-Conditioning Engineers, Inc. ASHRAE Standard 188-2015: Legionellosis: Risk management for building water systems (ANSI approved). 2015.

Beer KD, Gargano JW, Roberts VA, et al. Outbreaks associated with environmental and undetermined water exposures-United States, 2011-2012. MMWR Morb Mortal Wkly Rep 2015;64:849-51. http:// dx.doi.org/10.15585/mmwr.mm6431a3

Beer KD, Gargano JW, Roberts VA, et al. Surveillance for waterborne disease outbreaks associated with drinking water-United States, 2011-2012. MMWR Morb Mortal Wkly Rep 2015;64:842-8. http://dx.doi. org/10.15585/mmwr.mm6431a2

CDC. Legionellosis-United States, 2000-2009. MMWR Morb Mortal Wkly Rep 2011;60:1083-6.

CDC. Surveillance for travel-associated legionnaires disease-United States, 2005-2006. MMWR Morb Mortal Wkly Rep 2007;56:1261-3.

European Centre for Disease Prevention and Control. Legionnaires' disease in Europe, 2013. Stockholm, Sweden: ECDC; 2015. http:// ecdc.europa.eu/en/publications/_layouts/forms/Publication_DispForm. aspx?List $=4 f 55$ ad51-4aed-4d32-b960-af70113dbb90\&ID=1288

European Working Group on Legionella Infections. EWGLI technical guidelines for the investigation, control, and prevention of travel associated Legionnaires' disease. Stockholm, Sweden: ECDC; 2011. http://ecdc. europa.eu/en/healthtopics/legionnaires_disease/ELDSNet/Documents/ EWGLI-Technical-Guidelines.pdf

Fields BS, Benson RF, Besser RE. Legionella and Legionnaires' disease: 25 years of investigation. Clin Microbiol Rev 2002;15:506-26. http://dx.doi. org/10.1128/CMR.15.3.506-526.2002

Hlavsa MC, Roberts VA, Kahler AM, et al. Outbreaks of illness associated with recreational water-United States, 2011-2012. MMWR Morb Mortal Wkly Rep 2015;64:668-72.

Marston BJ, Lipman HB, Breiman RF. Surveillance for Legionnaires' disease. Risk factors for morbidity and mortality. Arch Intern Med 1994;154:241722. http://dx.doi.org/10.1001/archinte.1994.00420210049006

Neil K, Berkelman R. Increasing incidence of legionellosis in the United States, 1990-2005: changing epidemiologic trends. Clin Infect Dis 2008;47:591-9. http://dx.doi.org/10.1086/590557

\section{Leptospirosis}

Bharti AR, Nally JE, Ricaldi JN, et al. Leptospirosis: a zoonotic disease of global importance. Lancet Infect Dis 2003;3:757-71. http://dx.doi. org/10.1016/S1473-3099(03)00830-2

Chatfield J, Milleson M, Stoddard R, Bui DM, Galloway R. Serosurvey of leptospirosis in feral hogs (Sus scrofa) in Florida. J Zoo Wildl Med 2013;44:404-7. http://dx.doi.org/10.1638/2012-0258R2.1

Guerra MA. Leptospirosis. J Am Vet Med Assoc 2009;234:472-8,30.

Levett PN. Leptospirosis. Clin Microbiol Rev 2001;14:296-326. http:// dx.doi.org/10.1128/CMR.14.2.296-326.2001

\section{Listeriosis}

Cartwright EJ, Jackson KA, Johnson SD, Graves LM, Silk BJ, Mahon BE. Listeriosis outbreaks and associated food vehicles, United States, 1998-2008. Emerg Infect Dis 2013;19:1-9. http://dx.doi.org/10.3201/ eid1901.120393
CDC. Vital signs: Listeria illnesses, deaths, and outbreaks-United States, 2009-2011. MMWR Morb Mortal Wkly Rep 2013;62:448-52.

Maertens de Noordhout C, Devleesschauwer B, Angulo FJ, et al. The global burden of listeriosis: a systematic review and meta-analysis. Lancet Infect Dis 2014;14:1073-82. http://dx.doi.org/10.1016/ S1473-3099(14)70870-9

Heiman KE, Garalde VB, Gronostaj M, et al. Multistate outbreak of listeriosis caused by imported cheese and evidence of cross-contamination of other cheeses, USA, 2012. Epidemiol Infect 2015;1-11. http://dx.doi. org/10.1017/S095026881500117X

Jackson KA, Biggerstaff M, Tobin-D’Angelo M, et al. Multistate outbreak of Listeria monocytogenes associated with Mexican-style cheese made from pasteurized milk among pregnant, Hispanic women. J Food Prot 2011;74:949-53. http://dx.doi.org/10.4315/0362-028X.JFP-10-536

Jackson KA, Iwamoto M, Swerdlow D. Pregnancy-associated listeriosis. Epidemiol Infect 2010;138:1503-9. http://dx.doi.org/10.1017/ S0950268810000294

McCollum JT, Cronquist AB, Silk BJ, et al. Multistate outbreak of listeriosis associated with cantaloupe. N Engl J Med 2013;369:944-53. http:// dx.doi.org/10.1056/NEJMoa1215837

Pouillot R, Hoelzer K, Jackson KA, Henao OL, Silk BJ. Relative risk of listeriosis in Foodborne Diseases Active Surveillance Network (FoodNet) sites according to age, pregnancy, and ethnicity. Clin Infect Dis 2012;54(Suppl 5):S405-10. http://dx.doi.org/10.1093/cid/cis269

Scallan E, Hoekstra RM, Angulo FJ, et al. Foodborne illness acquired in the United States-major pathogens. Emerg Infect Dis 2011;17:7-15. http://dx.doi.org/10.3201/eid1701.P11101

Silk BJ, Date KA, Jackson KA, et al. Invasive listeriosis in the Foodborne Diseases Active Surveillance Network (FoodNet), 2004-2009: further targeted prevention needed for higher-risk groups. Clin Infect Dis 2012;54(Suppl 5):S396-404. http://dx.doi.org/10.1093/cid/cis268

Silk BJ, McCoy MH, Iwamoto M, Griffin PM. Foodborne listeriosis acquired in hospitals. Clin Infect Dis 2014;59:532-40. http://dx.doi. org/10.1093/cid/ciu365

\section{Lyme Disease}

Bacon RM, Kugeler KJ, Mead PS. Surveillance for Lyme disease-United States, 1992-2006. MMWR Surveill Summ 2008;57(No. SS-10):1-9.

Nelson C, Hojvat S, Johnson B, et al. Concerns regarding a new culture method for Borrelia burgdorferi not approved for the diagnosis of Lyme disease. MMWR Morb Mortal Wkly Rep 2014;63:333.

CDC. Three sudden cardiac deaths associated with Lyme carditisUnited States, November 2012-July 2013. MMWR Morb Mortal Wkly Rep 2013;62:993-6.

Hayes EB, Piesman J. How can we prevent Lyme disease? N Engl J Med 2003;348:2424-30. http://dx.doi.org/10.1056/NEJMra021397

Hinckley AF, Connally NP, Meek JI, et al. Lyme disease testing by large commercial laboratories in the United States. Clin Infect Dis 2014;59:676-81. http://dx.doi.org/10.1093/cid/ciu397

Kugeler KJ, Farley GM, Forrester JD, Mead PS. Geographic distribution and expansion of human Lyme disease, United States. Emerg Infect Dis 2015;21:1455-7. http://dx.doi.org/10.3201/eid2108.141878

Mead P, Hinckley A, Hook S, Beard CB. TickNET-A collaborative public health approach to tickborne disease surveillance and research. Emerg Infect Dis 2015;21:1574-7. http://dx.doi.org/10.3201/eid2109.150301

Nelson CA, Saha S, Kugeler KJ, et al. Incidence of clinician-diagnosed Lyme disease, United States, 2005-2010. Emerg Infect Dis 2015;21:1625-31. http://dx.doi.org/10.3201/eid2109.150417

Wormser GP, Dattwyler RJ, Shapiro ED, et al. The clinical assessment, treatment, and prevention of lyme disease, human granulocytic anaplasmosis, and babesiosis: clinical practice guidelines by the Infectious Diseases Society of America. Clin Infect Dis 2006;43:1089-134. http:// dx.doi.org/10.1086/508667 


\section{Malaria}

Abanyie FA, Arguin PM, Gutman J. State of malaria diagnostic testing at clinical laboratories in the United States, 2010: a nationwide survey. Malar J 2011;10:340. http://dx.doi.org/10.1186/1475-2875-10-340

Cullen KA, Mace KE, Arguin PM. Malaria Surveillance-United States, 2013. MMWR Surveill Summ 2016;65(No. SS-2):1-22. http://dx.doi. org/10.15585/mmwr.ss6502a1

Hwang J, Cullen KA, Kachur SP, Arguin PM, Baird JK. Severe morbidity and mortality risk from malaria in the United States, 1985-2011. Open Forum Infect Dis 2014;1:ofu034. http://dx.doi.org/10.1093/ofid/ofu034

Jensenius M, Han PV, Schlagenhauf P, et al. Acute and potentially lifethreatening tropical diseases in western travelers-a GeoSentinel multicenter study, 1996-2011. Am J Trop Med Hyg 2013;88:397-404. http://dx.doi.org/10.4269/ajtmh.12-0551

Krause G, Schöneberg I, Altmann D, Stark K. Chemoprophylaxis and malaria death rates. Emerg Infect Dis 2006;12:447-51. http://dx.doi. org/10.3201/eid1203.050736

\section{Measles}

McLean HQ, Fiebelkorn AP, Temte JL, Wallace GS. Prevention of measles, rubella, congenital rubella syndrome, and mumps, 2013: summary recommendations of the Advisory Committee on Immunization Practices (ACIP). MMWR Recomm Rep 2013;62(No.RR-4).

Papania MJ, Wallace GS, Rota PA, et al. Elimination of endemic measles, rubella, and congenital rubella syndrome from the Western hemisphere: the US experience. JAMA Pediatr 2014;168:148-55. http://dx.doi. org/10.1001/jamapediatrics.2013.4342

\section{Meningococcal Disease}

Cohn AC, MacNeil JR, Clark TA, et al. Prevention and control of meningococcal disease: recommendations of the Advisory Committee on Immunization Practices (ACIP). MMWR Recomm Rep 2013;62(No.RR-2).

Cohn AC, MacNeil JR, Harrison LH, et al. Changes in Neisseria meningitidis disease epidemiology in the United States, 1998-2007: implications for prevention of meningococcal disease. Clin Infect Dis 2010;50:184-91. http://dx.doi.org/10.1086/649209

Rosenstein NE, Perkins BA, Stephens DS, Popovic T, Hughes JM. Meningococcal disease. N Engl J Med 2001;344:1378-88. http://dx.doi. org/10.1056/NEJM200105033441807

\section{Mumps}

Fiebelkorn AP, Rosen JB, Brown C, et al. Environmental factors potentially associated with mumps transmission in yeshivas during a mumps outbreak among highly vaccinated students: Brooklyn, New York, 2009-2010. Hum Vaccin Immunother 2013;9:189-94. http://dx.doi.org/10.4161/ hv. 22415

Fiebelkorn AP, Lawler J, Curns AT, Brandeburg C, Wallace GS. Mumps postexposure prophylaxis with a third dose of measles-mumpsrubella vaccine, Orange County, New York, USA. Emerg Infect Dis 2013;19:1411-7. http://dx.doi.org/10.3201/eid1909.130299

\section{Novel Influenza A Virus}

CDC. Antibodies cross-reactive to influenza A (H3N2) variant virus and impact of 2010-11 seasonal influenza vaccine on cross-reactive antibodies-United States. MMWR Morb Mortal Wkly Rep 2012;61:237-41.
Ducatez MF, Hause B, Stigger-Rosser E, et al. Multiple reassortment between pandemic (H1N1) 2009 and endemic influenza viruses in pigs, United States. Emerg Infect Dis 2011;17:1624-9. http://dx.doi. org/10.3201/1709.110338

Epperson S, Jhung M, Richards S, et al. Human infections with influenza $\mathrm{A}(\mathrm{H} 3 \mathrm{~N} 2)$ variant virus in the United States, 2011-2012. Clin Infect Dis 2013;57(Suppl 1):S4-11. http://dx.doi.org/10.1093/cid/cit272

Jhung MA, Epperson S, Biggerstaff $M$, et al. Outbreak of variant influenza $\mathrm{A}(\mathrm{H} 3 \mathrm{~N} 2)$ virus in the United States. Clin Infect Dis 2013;57:1703-12. http://dx.doi.org/10.1093/cid/cit649

Myers KP, Olsen CW, Gray GC. Cases of swine influenza in humans: a review of the literature. Clin Infect Dis 2007;44:1084-8. http://dx.doi. org/10.1086/512813

Olsen CW. The emergence of novel swine influenza viruses in North America. Virus Res 2002;85:199-210. http://dx.doi.org/10.1016/ S0168-1702(02)00027-8

Shinde V, Bridges CB, Uyeki TM, et al. Triple-reassortant swine influenza A (H1) in humans in the United States, 2005-2009. N Engl J Med 2009;360:2616-25. http://dx.doi.org/10.1056/NEJMoa0903812

Vincent AL, Ma W, Lager KM, Janke BH, Richt JA. Swine influenza viruses a North American perspective. Adv Virus Res 2008;72:127-54. http:// dx.doi.org/10.1016/S0065-3527(08)00403-X

Vincent AL, Swenson SL, Lager KM, Gauger PC, Loiacono C, Zhang Y. Characterization of an influenza A virus isolated from pigs during an outbreak of respiratory disease in swine and people during a county fair in the United States. Vet Microbiol 2009;137:51-9. http://dx.doi. org/10.1016/j.vetmic.2009.01.003

\section{Pertussis}

Acosta AM, DeBolt C, Tasslimi A, et al. Tdap vaccine effectiveness in adolescents during the 2012 Washington State pertussis epidemic. Pediatrics 2015;135:981-9. http://dx.doi.org/10.1542/peds.2014-3358

CDC. Updated recommendations for use of tetanus toxoid, reduced diphtheria toxoid, and acellular pertussis (Tdap) vaccine in adults aged 65 years and older-Advisory Committee on Immunization Practices (ACIP), 2012. MMWR Morb Mortal Wkly Rep 2012;61:468-70.

CDC. Updated recommendations for use of tetanus toxoid, reduced diphtheria toxoid, and acellular pertussis vaccine (Tdap) in pregnant women-Advisory Committee on Immunization Practices (ACIP), 2012. MMWR Morb Mortal Wkly Rep 2013;62:131-5.

Skoff TH, Kenyon C, Cocoros N, et al. Sources of infant pertussis infection in the United States. Pediatrics 2015;136:635-41. http://dx.doi. org/10.1542/peds.2015-1120

\section{Plague}

Dennis DT, Gage KL, Gratz N, Poland JD, Tikhomirov E. Plague manual: epidemiology, distribution, surveillance, and control. Geneva, Switzerland: World Health Organization; 1999.

Inglesby TV, Dennis DT, Henderson DA, et al.; for the Working Group on Civilian Biodefense. Plague as a biological weapon: medical and public health management. JAMA 2000;283:2281-90. http://dx.doi. org/10.1001/jama.283.17.2281

Kugeler KJ, Staples JE, Hinckley AF, Gage KL, Mead PS. Epidemiology of human plague in the United States, 1900-2012. Emerg Infect Dis 2015;21:16-22. http://dx.doi.org/10.3201/eid2101.140564

Runfola JK, House J, Miller L, et al. Outbreak of human pneumonic plague with dog-to-human and possible human-to-human transmissionColorado, June-July 2014. MMWR Morb Mortal Wkly Rep 2015;64:429-34. 
Tourdjman M, Ibraheem M, Brett M, et al. Misidentification of Yersinia pestis by automated systems, resulting in delayed diagnoses of human plague infections-Oregon and New Mexico, 2010-2011. Clin Infect Dis 2012;55:e58-60. http://dx.doi.org/10.1093/cid/cis578

\section{Polio}

Alexander JP, Wallace G, Wassilak SG. Poliomyelitis. In: The Yellow Book: CDC health information for international travel, 2012. New York, NY: Oxford University Press; 2012.

\section{Q Fever}

Anderson A, Bijlmer H, Fournier PE, et al. Diagnosis and management of Q Fever-United States, 2013: recommendations from CDC and the Q Fever working group. MMWR Recomm Rep 2013;62(RR-3).

Dahlgren FS, McQuiston JH, Massung RF, Anderson AD. Q fever in the United States: summary of case reports from two national surveillance systems, 2000-2012. Am J Trop Med Hyg 2015;92:247-55. http://dx.doi. org/10.4269/ajtmh.14-0503

Robyn MP, Newman AP, Amato M, et al. Q Fever outbreak among travelers to Germany who received live cell therapy-United States and Canada, 2014. MMWR Morb Mortal Wkly Rep 2015;64:1071-3. http://dx.doi. org/10.15585/mmwr.mm6438a3

\section{Rabies}

CDC. Compendium of animal rabies prevention and control, 2011: National Association of State Public Health Veterinarians, Inc. MMWR Recomm Rep 2011;60(No. RR-6).

CDC. Human rabies prevention-United States, 2008: recommendation of the Advisory Committee on Immunization Practices (ACIP). MMWR Recomm Rep 2008;57(No. RR-3).

Rupprecht CE, Briggs D, Brown CM, et al. Use of a reduced (4-dose) vaccine schedule for postexposure prophylaxis to prevent human rabies: recommendations of the advisory committee on immunization practices. MMWR Recomm Rep 2010;59(No. RR-2).

Rubella, Congenital Rubella Syndrome

CDC. Three cases of congenital rubella syndrome in the postelimination era-Maryland, Alabama, and Illinois, 2012. MMWR Morb Mortal Wkly Rep 2013;62:226-9.

\section{Salmonellosis}

Chai SJ, White PL, Lathrop SL, et al. Salmonella enterica serotype Enteritidis: increasing incidence of domestically acquired infections. Clin Infect Dis 2012;54(Suppl 5):S488-97. http://dx.doi.org/10.1093/cid/cis231

Gaffga NH, Behravesh CB, Ettestad PJ, et al. Outbreak of salmonellosis linked to live poultry from a mail-order hatchery. N Engl J Med 2012;366:2065-73. http://dx.doi.org/10.1056/NEJMoa1111818

Guo C, Hoekstra RM, Schroeder CM, et al. Application of Bayesian techniques to model the burden of human salmonellosis attributable to U.S. food commodities at the point of processing: adaptation of a Danish model. Foodborne Pathog Dis 2011;8:509-16. http://dx.doi. org/10.1089/fpd.2010.0714

Jackson BR, Griffin PM, Cole D, Walsh KA, Chai SJ. Outbreak-associated Salmonella enterica serotypes and food Commodities, United States, 19982008. Emerg Infect Dis 2013;19:1239-44. http://dx.doi.org/10.3201/ eid1908.121511

Jones TF, Ingram LA, Cieslak PR, et al. Salmonellosis outcomes differ substantially by serotype. J Infect Dis 2008;198:109-14. http://dx.doi. org/10.1086/588823
Medalla F, Hoekstra RM, Whichard JM, et al. Increase in resistance to ceftriaxone and nonsusceptibility to ciprofloxacin and decrease in multidrug resistance among Salmonella strains, United States, 1996-2009. Foodborne Pathog Dis 2013;10:302-9. http://dx.doi.org/10.1089/ fpd.2012.1336

Painter JA, Hoekstra RM, Ayers T, et al. Attribution of foodborne illnesses, hospitalizations, and deaths to food commodities by using outbreak data, United States, 1998-2008. Emerg Infect Dis 2013;19:407-15. http:// dx.doi.org/10.3201/eid1903.111866

Scallan E, Mahon BE, Hoekstra RM, Griffin PM. Estimates of illnesses, hospitalizations and deaths caused by major bacterial enteric pathogens in young children in the United States. Pediatr Infect Dis J 2013;32:217-21.

\section{Shiga Toxin-producing Escherichia coli (STEC)}

Brooks JT, Sowers EG, Wells JG, et al. Non-O157 Shiga toxin-producing Escherichia coli infections in the United States, 1983-2002. J Infect Dis 2005;192:1422-9. http://dx.doi.org/10.1086/466536

Cronquist AB, Mody RK, Atkinson R, et al. Impacts of culture-independent diagnostic practices on public health surveillance for bacterial enteric pathogens. Clin Infect Dis 2012;54(Suppl 5):S432-9. http://dx.doi. org/10.1093/cid/cis267

Gould LH, Mody RK, Ong KL, et al. Increased recognition of non-O157 Shiga toxin-producing Escherichia coli infections in the United States during 2000-2010: epidemiologic features and comparison with E. coli O157 infections. Foodborne Pathog Dis 2013;10:453-60. http://dx.doi. org/10.1089/fpd.2012.1401

Hale CR, Scallan E, Cronquist AB, et al. Estimates of enteric illness attributable to contact with animals and their environments in the United States. Clin Infect Dis 2012;54(Suppl 5):S472-9. http://dx.doi. org $/ 10.1093 / \mathrm{cid} / \mathrm{cis} 051$

Jones TF, Gerner-Smidt P. Nonculture diagnostic tests for enteric diseases. Emerg Infect Dis 2012;18:513-4. http://dx.doi.org/10.3201/ eid1803.111914

Mody RK, Griffin PM. Fecal shedding of Shiga toxin-producing Escherichia coli: what should be done to prevent secondary cases? Clin Infect Dis 2013;56:1141-4. http://dx.doi.org/10.1093/cid/cis1222

Mody RK, Luna-Gierke RE, Jones TF, et al. Infections in pediatric postdiarrheal hemolytic uremic syndrome: factors associated with identifying shiga toxinproducing Escherichia coli. Arch Pediatr Adolesc Med 2012;166:902-9. http://dx.doi.org/10.1001/archpediatrics.2012.471

Tarr PI, Gordon CA, Chandler WL. Shiga-toxin-producing Escherichia coli and haemolytic uraemic syndrome. Lancet 2005;365:1073-86.

\section{Shigellosis}

Arvelo W, Hinkle CJ, Nguyen TA, et al. Transmission risk factors and treatment of pediatric shigellosis during a large daycare center-associated outbreak of multidrug resistant Shigella sonnei: implications for the management of shigellosis outbreaks among children. Pediatr Infect Dis J 2009;28:976-80. http://dx.doi.org/10.1097/INF.0b013e3181a76eab

Baker KS, Dallman TJ, Ashton PM, et al. Intercontinental dissemination of azithromycin-resistant shigellosis through sexual transmission: a cross-sectional study. Lancet Infect Dis 2015;15:913-21. http://dx.doi. org/10.1016/S1473-3099(15)00002-X

Gray MD, Lampel KA, Strockbine NA, Fernandez RE, Melton-Celsa AR, Maurelli AT. Clinical isolates of Shiga toxin 1a-producing Shigella flexneri with an epidemiological link to recent travel to Hispañiola. Emerg Infect Dis 2014;20:1669-77. http://dx.doi.org/10.3201/eid2010.140292 
Bowen A, Hurd J, Hoover C, et al. Importation and domestic transmission of Shigella sonnei resistant to ciprofloxacin-United States, May 2014February 2015. MMWR Morb Mortal Wkly Rep 2015;64:318-20.

CDC. Outbreaks of multidrug-resistant Shigella sonnei gastroenteritis associated with day care centers-Kansas, Kentucky, and Missouri, 2005. MMWR Morb Mortal Wkly Rep 2006;55:1068-71.

CDC. Outbreak of infections caused by Shigella sonnei with decreased susceptibility to azithromycin-Los Angeles, California, 2012. MMWR Morb Mortal Wkly Rep 2013;62:171.

Bowen A, Eikmeier D, Talley P, et al. Outbreaks of Shigella sonnei infection with decreased susceptibility to azithromycin among men who have sex with men-Chicago and Metropolitan Minneapolis-St. Paul, 2014. MMWR Morb Mortal Wkly Rep 2015;64:597-8.

Folster JP, Pecic G, Bowen A, Rickert R, Carattoli A, Whichard JM. Decreased susceptibility to ciprofloxacin among Shigella isolates in the United States, 2006 to 2009. Antimicrob Agents Chemother 2011;55:1758-60. http:// dx.doi.org/10.1128/AAC.01463-10

Garrett V, Bornschlegel K, Lange D, et al. A recurring outbreak of Shigella sonnei among traditionally observant Jewish children in New York City: the risks of daycare and household transmission. Epidemiol Infect 2006;134:1231-6. http://dx.doi.org/10.1017/S0950268806006182

Gupta A, Polyak CS, Bishop RD, Sobel J, Mintz ED. Laboratoryconfirmed shigellosis in the United States, 1989-2002: epidemiologic trends and patterns. Clin Infect Dis 2004;38:1372-7. http://dx.doi. org/10.1086/386326

Haley CC, Ong KL, Hedberg K, et al. Risk factors for sporadic shigellosis, FoodNet 2005. Foodborne Pathog Dis 2010;7:741-7. http://dx.doi. org/10.1089/fpd.2009.0448

Howie RL, Folster JP, Bowen A, Barzilay EJ, Whichard JM. Reduced azithromycin susceptibility in Shigella sonnei, United States. Microb Drug Resist 2010;16:245-8. http://dx.doi.org/10.1089/mdr.2010.0028

Lederer I, Taus K, Allerberger F, et al. Shigellosis in refugees, Austria, July to November 2015. Euro Surveill 2015;20:30081. http://dx.doi. org/10.2807/1560-7917.ES.2015.20.48.30081

Nygren BL, Schilling KA, Blanton EM, Silk BJ, Cole DJ, Mintz ED. Foodborne outbreaks of shigellosis in the USA, 1998-2008. Epidemiol Infect 2013;141:233-41. http://dx.doi.org/10.1017/ S0950268812000222

\section{Spotted Fever Rickettsiosis (Including Rocky Mountain Spotted Fever)}

CDC. Diagnosis and management of tickborne rickettsial diseases: Rocky Mountain spotted fever and other spotted fever group rickettsioses, ehrlichioses, and anaplasmosis-United States: a practical guide for health care and public health professionals. MMWR Recomm Rep 2016;65(No. RR-2).

Dahlgren FS, Paddock CD, Springer YP, Eisen RJ, Behravesh CB. Expanding range of Amblyomma Americanum and simultaneous changes in the epidemiology of spotted fever group Rickettsiosis in the United States, 1999-2007. Am J Trop Med Hyg 2016;94:35-42.

Drexler N, Dahlgren FS, Nichols Heitman K, Massung RF, Paddock CD, Barton Behravesh C. National surveillance of spotted fever group Rickettsiosis in the United States, 2008-2012. Am J Trop Med Hyg 2016;94:26-34.

Johnston SH, Glaser CA, Padgett K, et al. Rickettsia spp. 364D causing a cluster of eschar-associated illness, California. Pediatr Infect Dis J 2013;32:1036-9. http://dx.doi.org/10.1097/INF.0b013e318296b24b

Paddock CD, Goddard J. The evolving medical and veterinary importance of the Gulf Coast tick (Acari: Ixodidae). J Med Entomol 2015;52:230-52. http://dx.doi.org/10.1093/jme/tju022

\section{Streptococcal Toxic Shock Syndrome}

CDC. Active Bacterial Core Surveillance Report, Emerging Infections Program Network, Group A Streptococcus, 2014-provisional. http://www. cdc.gov/abcs/reports-findings/survreports/gas14.pdf

CDC. Investigating clusters of group A streptococcal disease. Atlanta, GA: US Department of Health and Human Services, CDC; 2009. http:// www2a.cdc.gov/ncidod/dbmd/abcs/calc/calc_new/calculator.html

Dale JB, Fischetti VA, Carapetis JR, et al. Group A streptococcal vaccines: paving a path for accelerated development. Vaccine 2013;31(Suppl 2):B216-22. http://dx.doi.org/10.1016/j.vaccine.2012.09.045

Nelson GE, Pondo T, Toews KA, et al. Epidemiology of invasive group A streptococcal infections in the United States, 2005-2012. Clin Infect Dis 2016;63:478-86.

Prevention of Invasive Group A Streptococcal Infections Workshop Participants. Prevention of invasive group A streptococcal disease among household contacts of case patients and among postpartum and postsurgical patients: recommendations from the Centers for Disease Control and Prevention. Clin Infect Dis 2002;35:950-9. http://dx.doi. org/10.1086/342692

\section{Syphilis, Congenital}

Bowen V, Su J, Torrone E, Kidd S, Weinstock H. Increase in incidence of congenital syphilis_-United States, 2012. MMWR Morb Mortal Wkly Rep 2015;64:1241-5. http://dx.doi.org/10.15585/mmwr.mm6444a3

CDC. Sexually transmitted disease surveillance, 2014. Atlanta, GA: US Department of Health and Human Services, CDC; 2015.

Workowski KA, Bolan GA. Sexually transmitted diseases treatment guidelines, 2015. MMWR Recomm Rep 2015;64(No. RR-3).

\section{Syphilis, Primary and Secondary}

Patton ME, Su JR, Nelson R, Weinstock H. Primary and secondary syphilis-United States, 2005-2013. MMWR Morb Mortal Wkly Rep 2014;63:402-6.

CDC. Sexually transmitted disease surveillance, 2014. Atlanta, GA: US Department of Health and Human Services, CDC; 2015.

Workowski KA, Bolan GA. Sexually transmitted diseases treatment guidelines, 2015. MMWR Recomm Rep 2015;64(No. RR-3).

\section{Tetanus}

CDC. Tetanus-Puerto Rico, 2002. MMWR Morb Mortal Wkly Rep 2002;51:613-5.

Khetsuriani N, Zakikhany K, Jabirov S, et al. Seroepidemiology of diphtheria and tetanus among children and young adults in Tajikistan: nationwide population-based survey, 2010. Vaccine 2013;31:4917-22. http://dx.doi. org/10.1016/j.vaccine.2013.07.015

McQuillan GM, Kruszon-Moran D, Deforest A, Chu SY, Wharton M. Serologic immunity to diphtheria and tetanus in the United States. Ann Intern Med 2002;136:660-6. http://dx.doi. org/10.7326/0003-4819-136-9-200205070-00008

Pascual FB, McGinley EL, Zanardi LR, Cortese MM, Murphy TV. Tetanus surveillance-United States, 1998-2000. MMWR Surveill Summ 2003;52(No. SS-3).

Roper M, Wassilak S, Tiwari T, Orenstein W. Tetanus toxoid In: Plotkin O, Orenstein W, Offitt P (Eds.). Vaccines 2013. 


\section{Trichinellosis}

CDC. Trichinellosis caused by consumption of wild boar meat-Illinois, 2013. MMWR Morb Mortal Wkly Rep 2014;63:451.

Gamble HR, Bessonov AS, Cuperlovic K, et al. International Commission on Trichinellosis: recommendations on methods for the control of Trichinella in domestic and wild animals intended for human consumption. Vet Parasitol 2000;93:393-408. http://dx.doi.org/10.1016/ S0304-4017(00)00354-X

Gottstein B, Pozio E, Nöckler K. Epidemiology, diagnosis, treatment, and control of trichinellosis. Clin Microbiol Rev 2009;22:127-45. http:// dx.doi.org/10.1128/CMR.00026-08

Holzbauer SM, Agger WA, Hall RL, et al. Outbreak of Trichinella spiralis infections associated with a wild boar hunted at a game farm in Iowa. Clin Infect Dis 2014;59:1750-6. http://dx.doi.org/10.1093/cid/ciu713

Kennedy ED, Hall RL, Montgomery SP, Pyburn DG, Jones JL. Trichinellosis surveillance-United States, 2002-2007. MMWR Surveill Summ 2009;58(No. SS-9).

Roy SL, Lopez AS, Schantz PM. Trichinellosis surveillance-United States, 1997-2001. MMWR Surveill Summ 2003;52(No. SS-6).

Wilson NO, Hall RL, Montgomery SP, Jones JL. Trichinellosis surveillanceUnited States, 2008-2012. MMWR Surveill Summ 2015;64(No. SS-1).

\section{Tuberculosis}

CDC. Reported tuberculosis in the United States, 2014. Atlanta, GA: U.S. Department of Health and Human Services, CDC; 2015.

Manangan LP, Tryon C, Magee E, Miramontes R. Innovative qualityassurance strategies for tuberculosis surveillance in the United States. Tuberc Res Treat 2012;481230. http://dx.doi.org/10.1155/2012/481230

Scott C, Kirking HL, Jeffries C, Price SF, Pratt R. Tuberculosis trendsUnited States, 2014. MMWR Morb Mortal Wkly Rep 2015;64:265-9.

Woodruff RS, Winston CA, Miramontes R. Predicting U.S. tuberculosis case counts through 2020. PLoS One 2013;8:e65276. http://dx.doi. org/10.1371/journal.pone.0065276

Yelk Woodruff RS, Pratt RH, Armstrong LR. The US National Tuberculosis Surveillance System: A descriptive assessment of the completeness and consistency of data reported from 2008 to 2012. JMIR Public Health Surveill 2015;1:e15. http://dx.doi.org/10.2196/publichealth.4991

\section{Tularemia}

CDC. Tularemia_United States, 2001-2010. MMWR Morb Mortal Wkly Rep 2013;62:963-6.

Dennis DT, Inglesby TV, Henderson DA, et al. Tularemia as a biological weapon: medical and public health management. JAMA 2001;285:276373. http://dx.doi.org/10.1001/jama.285.21.2763

Kugeler KJ, Mead PS, Janusz AM, et al. Molecular epidemiology of Francisella tularensis in the United States. Clin Infect Dis 2009;48:863-70. http:// dx.doi.org/10.1086/597261

Tarnvik A. WHO guidelines on tularemia. Geneva, Switzerland: World Health Organization; 2007.

Weber IB, Turabelidze G, Patrick S, Griffith KS, Kugeler KJ, Mead PS. Clinical recognition and management of tularemia in Missouri: a retrospective records review of 121 cases. Clin Infect Dis 2012;55:128390. http://dx.doi.org/10.1093/cid/cis706

\section{Typhoid Fever}

Imanishi M, Newton AE, Vieira AR, et al. Typhoid fever acquired in the United States, 1999-2010: epidemiology, microbiology, and use of a space-time scan statistic for outbreak detection. Epidemiol Infect 2015;143:2343-54. http://dx.doi.org/10.1017/S0950268814003021

Loharikar A, Newton A, Rowley P, et al. Typhoid fever outbreak associated with frozen mamey pulp imported from Guatemala to the western United States, 2010. Clin Infect Dis 2012;55:61-6. http://dx.doi. org/10.1093/cid/cis296

Lynch MF, Blanton EM, Bulens S, et al. Typhoid fever in the United States, 1999-2006. JAMA 2009;302:859-65. http://dx.doi.org/10.1001/ jama.2009.1229

Mahon BE, Newton AE, Mintz ED. Effectiveness of typhoid vaccination in US travelers. Vaccine 2014;32:3577-9. http://dx.doi.org/10.1016/j. vaccine.2014.04.055

Olsen SJ, Bleasdale SC, Magnano AR, et al. Outbreaks of typhoid fever in the United States, 1960-99. Epidemiol Infect 2003;130:13-21.

Steinberg EB, Bishop R, Haber P, et al. Typhoid fever in travelers: who should be targeted for prevention? Clin Infect Dis 2004;39:186-91. http://dx.doi.org/10.1086/421945

\section{Varicella}

Bialek SR, Perella D, Zhang J, et al. Impact of a routine two-dose varicella vaccination program on varicella epidemiology. Pediatrics 2013;132:e1134-40. http://dx.doi.org/10.1542/peds.2013-0863

CDC. Evolution of varicella surveillance - selected states, 2000-2010. MMWR Morb Mortal Wkly Rep 2012;61:609-12.

Marin M, Güris D, Chaves SS, Schmid S, Seward JF. Prevention of varicella: recommendations of the Advisory Committee on Immunization Practices (ACIP). MMWR Recomm Rep 2007;56(No. RR-4).

Lopez AS, Zhang J, Brown C, Bialek S. Varicella-related hospitalizations in the United States, 2000-2006: the 1-dose varicella vaccination era. Pediatrics 2011;127:238-45. http://dx.doi.org/10.1542/peds.2010-0962

Marin M, Zhang JX, Seward JF. Near elimination of varicella deaths in the US after implementation of the vaccination program. Pediatrics 2011;128:214-20. http://dx.doi.org/10.1542/peds.2010-3385

\section{Vibriosis}

Daniels NA, MacKinnon L, Bishop R, et al. Vibrio parahaemolyticus infections in the United States, 1973-1998. J Infect Dis 2000;181:16616. http://dx.doi.org/10.1086/315459

Dechet AM, Yu PA, Koram N, Painter J. Nonfoodborne Vibrio infections: an important cause of morbidity and mortality in the United States, 19972006. Clin Infect Dis 2008;46:970-6. http://dx.doi.org/10.1086/529148

McLaughlin JB, DePaola A, Bopp CA, et al. Outbreak of Vibrio parahaemolyticus gastroenteritis associated with Alaskan oysters. N Engl J Med 2005;353:1463-70. http://dx.doi.org/10.1056/NEJMoa051594

Newton AE, Garrett N, Stroika SG, Halpin JL, Turnsek M, Mody RK. Increase in Vibrio parahaemolyticus infections associated with consumption of Atlantic Coast shellfish-2013. MMWR Morb Mortal Wkly Rep 2014;63:335-6.

Newton A, Kendall M, Vugia DJ, Henao OL, Mahon BE. Increasing rates of vibriosis in the United States, 1996-2010: review of surveillance data from 2 systems. Clin Infect Dis 2012;54(Suppl 5):S391-5. http://dx.doi. org $/ 10.1093 / \mathrm{cid} / \mathrm{cis} 243$ 
Shapiro RL, Altekruse S, Hutwagner L, et al. The role of Gulf Coast oysters harvested in warmer months in Vibrio vulnificus infections in the United States, 1988-1996. J Infect Dis 1998;178:752-9. http://dx.doi. org/10.1086/515367

Tobin-D'Angelo M, Smith AR, Bulens SN, et al. Severe diarrhea caused by cholera toxin-producing vibrio cholerae serogroup $\mathrm{O} 75$ infections acquired in the southeastern United States. Clin Infect Dis 2008;47:1035-40. http://dx.doi.org/10.1086/591973

Vugia DJ, Tabnak F, Newton AE, Hernandez M, Griffin PM. Impact of 2003 state regulation on raw oyster-associated Vibrio vulnificus illnesses and deaths, California, USA. Emerg Infect Dis 2013;19:1276-80. http:// dx.doi.org/10.3201/eid1908.121861

\section{Viral Hemorrhagic Fevers}

Amorosa V, MacNeil A, McConnell R, et al. Imported Lassa fever, Pennsylvania, USA, 2010. Emerg Infect Dis 2010;16:1598-600. http:// dx.doi.org/10.3201/eid1610.100774

CDC. Imported case of Marburg hemorrhagic fever-Colorado, 2008. MMWR Morb Mortal Wkly Rep 2009;58:1377-81.

Ergönül O. Crimean-Congo haemorrhagic fever. Lancet Infect Dis 2006;6:203-14. http://dx.doi.org/10.1016/S1473-3099(06)70435-2

Fichet-Calvet E, Rogers DJ. Risk maps of Lassa fever in West Africa. PLoS Negl Trop Dis 2009;3:e388. http://dx.doi.org/10.1371/journal. pntd.0000388

Rollin PE, Nichol ST, Zaki S, Ksiazek TG. Arenaviruses and filoviruses. In: Murray PR, Baron EJ, Landry ML, Jorgensen JH, Pfaller MA, eds. Manual of clinical microbiology, 11th edition. Washington, DC: ASM Press; 2015:1669-86. 

The Morbidity and Mortality Weekly Report (MMWR) Series is prepared by the Centers for Disease Control and Prevention (CDC) and is available free of charge in electronic format. To receive an electronic copy each week, visit MMWR's free subscription page at http://www.cdc.gov/mmwr/mmwrsubscribe. $\mathrm{html}$. Paper copy subscriptions are available through the Superintendent of Documents, U.S. Government Printing Office, Washington, DC 20402; telephone 202-512-1800.

Readers who have difficulty accessing this PDF file may access the HTML file at http://www.cdc.gov/mmwr/mmwr_nd/index.html. Address all inquiries about the $M M W R$ Series, including material to be considered for publication, to Executive Editor, MMWR Series, Mailstop E-90, CDC, 1600 Clifton Rd., N.E., Atlanta, GA 30329-4027 or to mmwrq@cdc.gov.

All material in the MMWR Series is in the public domain and may be used and reprinted without permission; citation as to source, however, is appreciated. Use of trade names and commercial sources is for identification only and does not imply endorsement by the U.S. Department of Health and Human Services.

References to non-CDC sites on the Internet are provided as a service to $M M W R$ readers and do not constitute or imply endorsement of these organizations or their programs by CDC or the U.S. Department of Health and Human Services. CDC is not responsible for the content of these sites. URL addresses listed in $M M W R$ were current as of the date of publication.

ISSN: 0149-2195 (Print) 